1. (1) H (1) (1) -

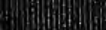

(N)

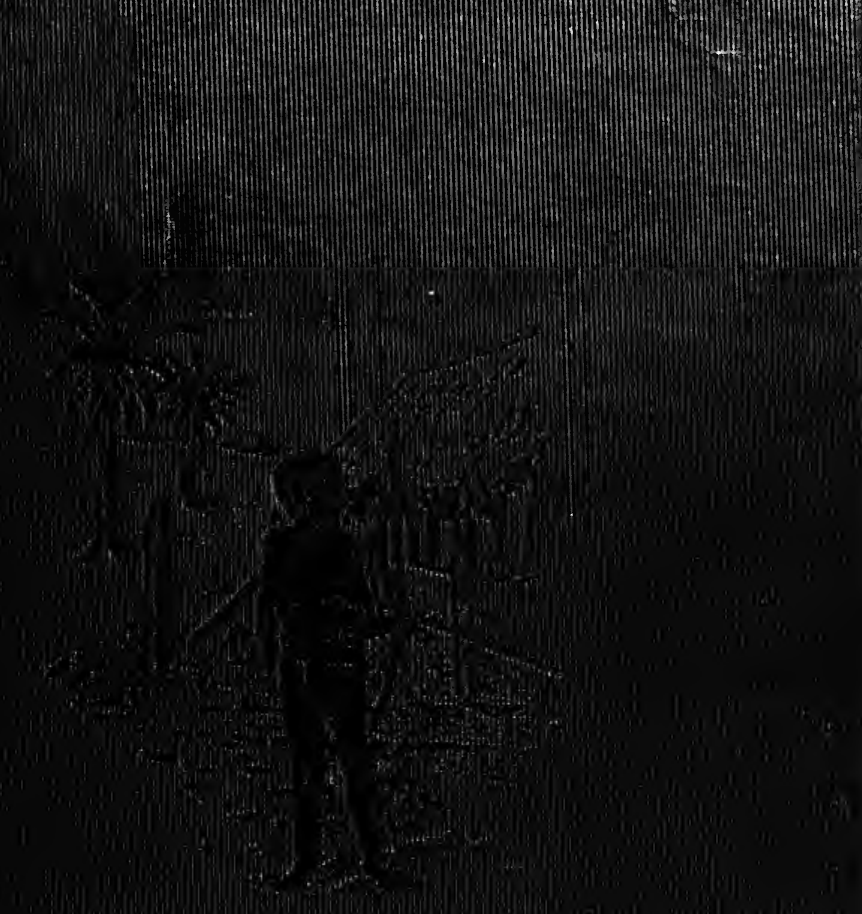




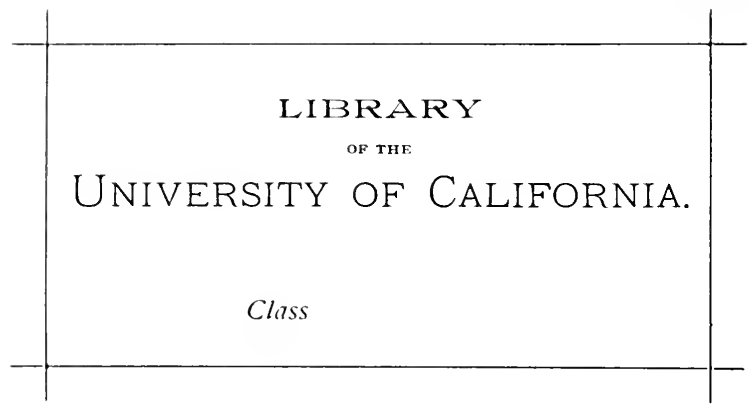


Digitized by the Internet Archive in 2008 with funding from Microsoft Corporation 

FIJI AND ITS POSSIBILITIES 
THE GEOGRAPHICAL LIBRARY

Nearest the Pole,

Fighting the Polar Ice,

By Robert E. Pcary, U. S. N.

The Awakening of China, By Anthony Fiala

The Opening of Tibet, Bv Dr. W. A. P. Martin

The Passing of Korea,

Flashlights in the Jungle,

By Perceval Landon

By Homer B. Hulbort, A. M.

By C. G. Schillings 
<smiles>[C]1CCCCC1</smiles> 


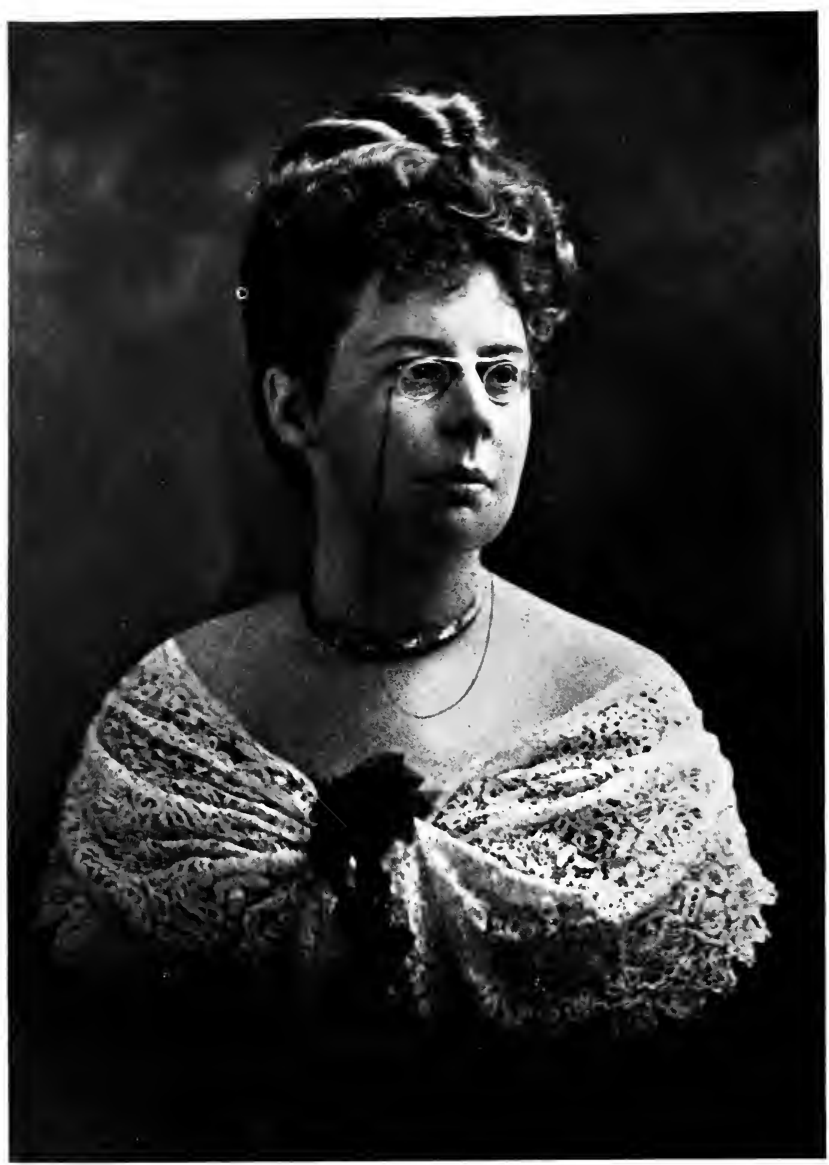

Beratice Grimshany. 


\title{
Fiji and its Possibilities
}

\author{
By \\ BEATRICE GRIMSHAW
}

\author{
Illustrated from \\ photographs
}
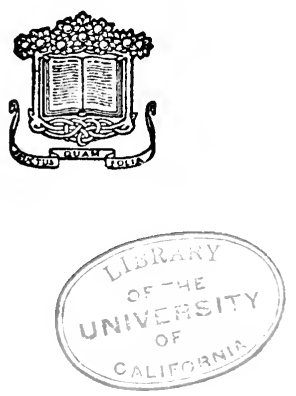

New York

Doubleday, Page \& Company

1907 
COPYRIGHT, 1907, BY DOUBLEDAY, PAGE \& COMPANY

Published, September, 1907

Alt Rights Reserved

INCLUDING THAT OP TRANSLATION INTO FOREIGN LANGUAges INCluding the Scandinavian

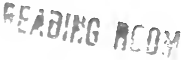




\section{PUBLISHERS' NOTE}

THIS STORY FIRST APPEARED IN ENGLAND UNDER

THE TITLE "FROM FIJI TO THE CANNIBAL ISLANDS" 



\section{CONTENTS}

Chapter I. Descriptive and Humorous. . . . . . .

A Far Cry to Fiji-The Wonderful Hills-History of Fiji-Link Between Eastern and Western Pacific-The Days of Thakombau-How the Colony is GovernedTrade of the Islands-The Humours of the Penal System

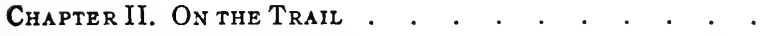

Garden of the Swiss Family Robinson-Over the Hills and Far Away-The Pandanus Prairies-Fijian Luggage -The Curse of the Spotted Bun-A Tropical ForestBenighted on the Way

Chapter III. Native Food-A Fijian Home

Night in a Fijian House-A Colossal Bed-The City of a Dream-A Fascinating Fijian-How to Drink Yanggona -Wanted, a Stanley-Where are the Settlers?-The Fairy Fortress

Chapter IV. Hospitality

"Plenty Shark"-Introduction to a Mbili-mbili-Down the Singatoka River-A Meké-meké at Mavua-Thalassa!

Chapter V. Personal Impressions

The Song of the Road-Fijian Fun-Night on the Wainikoro-The Noble Savage Fails-The Village Plate-The Lot of the Kaisi-Sharks Again-A Swim for it 
Chapter VI. Contrasting Scenes

Off to the Ndreketi-Fijian Smart Society-A Native Princess-The Sugar-cane Dance-Getting Bogged-The Use of Bad Language-The Ndreketi River-A Splendid Timber Country-A Native Diary-Truth About Tropical Forests-How to Live on Nothing a Day

Chapter VII. Industrial Surprises

At the Back of Beyond-The Last of the Cannibals-A Pleasant Old Devil-The Plague of Fleas-When Gideon Went Wild-Nanduri Once More-The Vanilla Planters -Cattle-ranching in Fiji

Chapter Vili. An Anglo-French Dilemma

The Mysterious Islands-Where No One Goes-What Happened to the Cook-A Fairy Harbour-Extraordinary Vila-History of the New Hebrides-What France Intends

Chapter IX. The New Hebrides

New Hebridean Natives-Life in an Explosive Magazine - The Delights of Dynamite Fishing-The Sapphire and Snow Méle-On a Coffee Plantation-Plan to Eat a Planter-The Recruiting System-The Flowering of the Coffee

Chapter X. Malekula-An Uncanny Place

Bound for Sou'-West Bay-The Wandering SteamerThe Marriage Market in Malekula-An Avenue of Idols-The Unknown Country-A Stronghold of Savagery-Ten Stick Island

Chapter Xi. Malekula-The Outer Man

How Bilyas Made Itself Strong-The Slaughtered Traders -Into the Unknown Country-The Cannibal ToiletNew Fashions in Murder-The Ignorant White Woman 
Chapter XiI. Malekula-The Inner Man

How a Malekulan Town is Defended-The Idol DanceFintimbus and the Pig-Gregorian Chant in the Wilderness-What are the Malekulans?-An Interview with a Cannibal Chief-The Lost Opportunity-No Admittance to the Temple-A Marvellous Mummy-The Bluebeard Chamber-Making a Conical Skull-The Captain's Story

Chapter XIII. Malekula-Pagan and Warlike

Idols of the New Hebrides-The Famous Poisoned Arrows-The Threatened Schooner-The Breaking of Navaar-An Ill-natured Sea-chief

Chapter XIV. Hot Times in Tanna

Hot Times in Tanna-An Island of Murderers-The Terror that Walks in Darkness-A Tannese VillageAvenging a Chieftain-Was it an Accident?-A Council of War-Netik-The Work of British-made Bullets

Chapter XV. Tanna-Its Scenery and Resources 257

Somebody's Picnic-The Simple Life in Tanna-The Returned Labour Trouble-Up the Great Volcano-The Valley of Fire

Chapter XVI. Norfolk Island-Good-bye . . . . 279

The Story of Norfolk Island-A Woman in the Case-The Fate of the Mutineers-In the New Home-A Valley of Peace-Good-bye 



\section{ILLUSTRATIONS}

Beatrice Grimshaw

Frontispiece

Fijian chiefs and armed native constabulary PACING PAGE Fijian chief Armed native constabulary $\quad . \quad$. $\quad . \quad$. 17

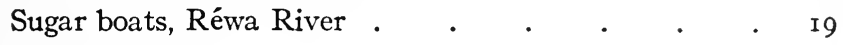

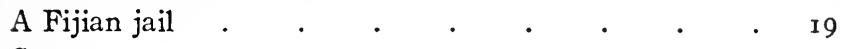
Coca Cinnamon

A mountain house Joni making fire

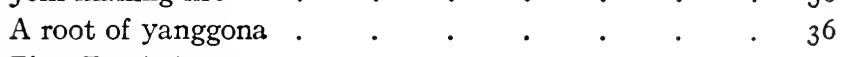

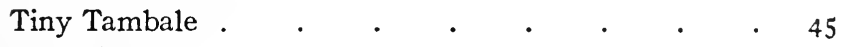
The ndalo beds $\quad . \quad$. $\quad . \quad$. $\quad . \quad$. 45 Yanggona bushes . . . . . . . . 45 House of the Turanga Liléwa . . . . . 62 A feast by the way . . . . . . . 65 Bringing up the yams . . . . . . 65 Morning, Lemba-Lemba . . . . . . $7 \mathrm{I}$ The Buli of Lemba-Lemba, with father and family. . 7 I My followers on the Mbili-Mbili . . . . $\quad 74$ Getting ready for the meké-meké . . . . 74 "Three Sisters" Mountain, Vanua Levu . . . 86 The village plate . . . . . . . 95 Unpeopled country . $\quad . \quad$. $\quad . \quad$. $\quad . \quad 95$ The boatless Wainikoro $\quad . \quad$. $\quad . \quad$. 98 The wild pineapples . $\quad . \quad$. $\quad . \quad$. $\quad 98$ Makarita in festival dress . . . . . . . 103 Makarita in Sunday dress . . . . . . . 103 Sunday morning in Nanduri . . . . . . 106 
The sugar-cane dance

In the prince's house-Fijian bed

The wood-cutter

A dakua tree

"Bad Lot"

The "Tevoro".

Vanilla

On a cocoanut plantation

Drying vanilla.

The Anglo-French Naval Commission . . . . I40

H. M. S. Pegasus

I 40

Entering the stock-yards . . . . . . I49

Havana Harbour, Efaté . . . . . . . $\quad$ I49

Coffee-drying . $\quad . \quad$. $\quad . \quad$. $\quad . \quad$. $\quad$ I 72

Coffee in flower. . . . . . . . . $\quad$ r 72

The refuge island of Wala-natives coming home to sleep. $\quad$ I79

The avenue of idols . $\quad . \quad$. $\quad . \quad$. $\quad$. 179

Chief's collection of boar tusks and jaws . . . ${ }_{1} 8_{4}$

Afraid to land-Sou'-West Bay . . . . . . $\quad$ r98

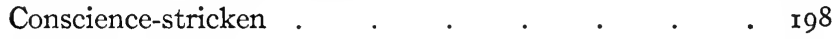

Malekula warrior . . . . . . . . 203

The women's dance . . . . . . . 2II

Dancing and singing . . . . . . . . $2 I I$

The dance of Atamat and Fintimbus . . . . 2 I 3

A dancing mask . . . . . . . . $2 \mathrm{I} 3$

The forbidden temple . . . . . . . 2 I 5

Bringing out the mummy . . . . . 218

Town of Lemba-Lemba . . . . . . 220

Infant head-binding . . . . . . . 220

Typical idols . $\quad . \quad$. $\quad . \quad$. $\quad . \quad$. 227

"Wishing-arch" idol . . . . . . . . . 229

The strange-faced idol . . . . . . 229

A notorious cannibal . . . . . . . . 234

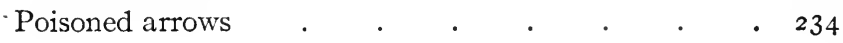


Tannese scar-tattooing

$\cdot \cdot \cdot 233$

Shooting fish ..$\quad \cdot \quad \cdot \quad \cdot \quad \cdot \quad \cdot 240$

Night refuge $. \quad . \quad . \quad . \quad . \quad . \quad . \quad .240$

In the yam fields . $\quad . \quad$. $\quad . \quad$. 243

The bad old man . . . . . . . 245

Looking out for trouble . . . . . . . 247

The allies coming in . . . . . . . 247

The council of war-the speaker for war . . . 250

The council of war-"What was that?" . . . 250

Tannese woman . . . . . . . 252

Tanna man . . . . . . . . . 252

Tannese girl climbing a cocoanut palm . . . 259

At the foot of the cone . . . . . . 270

Bushmen coming to see a white child . . . . 275

Fashions in Erromanga . . . . . . 275

"After life's fitful fever" . . . . . . . 282

The shore road, Norfolk Island . . . . . 282

Captain Drake, R. N., and Mrs. Drake. Government

House . . . . . . . 286

Garden fence of whales' ribs and vertebræ . . . 286

Tennis, Norfolk Island . . . . . . 292

Government House, Norfolk Island • • . 292 


\section{FIJI AND ITS POSSIBILITIES}


… 


\section{FIJI AND ITS POSSIBILITIES}

\section{CHAPTER I}

\section{DESCRIPTIVE AND HUMOROUS}

A FarCry to Fiji-The Wonderful Hills-History of Fiji-

Link between Eastern and Western Pacific-The Days of Thakombau-How the Colony is GovernedTrade of the Islands-The Humours of the Penal System

TT IS a "far cry" to Fiji. Take ship from London, sail 1 down the coasts of France and Spain, journey up the Mediterranean, by Scylla and Charybdis, and all the ancient world; reach Port Said, pass through the Gateways of the East, and steam through the torrid Red Sea into the Indian Ocean-and as yet you have hardly started. A little further, and one comes to sun-baked Aden, and sees the India-bound passengers leave the ship, congratulating themselves that the long tiresome voyage is over now. . . . Ceylon, and the magnificent East, lift like a splendid comet on the horizon, glow for one gorgeous day, and slip back into the past. Now the East lies behind, and the West is long forgotten, and what is there to come?

The South is still to come-the wide, free, wonderful world that lies below the Line, and that is as utterly unlike all things met with above, as the countries East of Suez are unlike the countries lying West, in outworn, unmysterious Europe. 
Happenings are largely a matter of latitude. About the fiftieth parallel, nothing interesting happens but policemen, bankruptcies, and Lord Mayors' shows. (Millionaires also happen-if you wish to be a millionaire you must on no account stray below forty north-but millionaires are not interesting, only instructive-in the uselessness of money.)

Down toward the thirties, colour begins to glow upon the gray outlines of Northern life, and in the twenties, strange scenes and astonishing peoples paint it over and over. Cross the Line, and now you may take the brush, and indulge your vagrant fancy to the full, for nothing that you can paint will be too bright or too strange. Below the equator is the world of the south, and here anything may happen, for here the new and the wild and the untried countries lie, and here, moreover, you shall come upon unknown tracts and places in yourself, on which, if you had stayed within sound of the roaring throat of Piccadilly, no sun had ever shone.

And as yet, we are scarce half-way on our journey. More weeks slip by, and, yellow, nude, and harsh, West Australia of the goldfields and the great unvisited plains lies on our port bow. More days, and sparkling Melbourne is passed, and Tasmania has sunk below the horizon, and still we are travelling on. . . . Sydney, bright and eager and curiously young (where have all the graybeards hidden themselves? or are they all at home in the old gray lands that suit their outworn souls?), is forgotten, and the great English ship is left at the quay, making ready for the homeward journey, and still, in another vessel, for ever and ever, as it seems, we are going on. . . . Seven weeks now since we sailed from Tilbury in a storm of parting cheers, friendly faces, wet with driving English rain, and with something 
more, growing white and far away upon the pier-and still the blue seas run in an unceasing river past our rail, and we sleep at night to the sound of beating waves. . . .

It is nearly eight weeks now, but the eighth will not be completed. One morning we are all waked early by the sound of the steamer shrieking for a pilot, and when we hurry on deck, we are confronted by a sparkling harbour, a green lagoon, and a pile of the most extraordinary and incredible mountain ranges ever seen outside the dreams of a delirious scene painter. There are peaks three and four thousand feet high, the colour of a purple thundercloud, jagged and pinked like broken saws; peaks like side-saddles, peaks like solitary, mysterious altars raised to some unknown god, and in the heart of the glowing violet distance, one single summit fashioned like a giant finger, pointing darkly to the sky.

Opposite the hills lies a pretty little town, under the shelter of rich-green wooded heights. A quay runs out from the land, and there are wharf officials, and customhouse men on the quay, and in the background welldressed men and ladies all in white, and carriages and in a word, civilisation-the last thing that we expected, here at the ends of the earth.

It is some time before the new-comer realises that Suva, the capital, is to Fiji in general as the feather in the factory-girl's hat to the rest of her attire. Such a splendid level as this is only attainable locally, and the rest of the country suffers by comparison almost as much as the decaying garments of Mary Ann from Bermondsey pale before the proximity of that marvellous erection of feathers and tinsel on her head. Still, to the traveller from home, who has probably arrived with undefined fears of "savages" about the beach, and the roughest 
of tavern accommodation in the town, the first impression is astonishing.

Suva, on landing, proves to be a good-sized town, with a long handsome main street, edged on one side by neatly cut grass, and great flamboyant trees in full flower of vivid scarlet, bordering the still, green, waveless lagoon that lies inside the barrier reef. On the other side stand shops with big plate-glass windows, clubs, offices, hotels. A little way out of the town is Government House, perched upon its own high hill to catch the trade wind-long and wide and deeply verandaed, with a tall flag-staff bearing the Union Jack on the roof, armed native sentries pacing at the avenue gates, and a stately flight of steps leading to the porch, to be covered with red carpet on great occasions. . . . And this is savage Fiji!

When we have chosen a hotel, disposed of our luggage, dined, and settled down to have a rest on the coolest veranda-for it is exceedingly hot, and the laziness of the Pacific world begins to press hard upon us-we may as well try to increase our understanding of the place where we find ourselves, by reading it up, until the heat and the sleepy swing of the long cane rocking-chair shall prove too much.

Fiji is a British Crown Colony, situated in the Southwest Pacific, lying between the 15 th and 22 nd parallels of south latitude, and between $\mathrm{I}_{57} \mathrm{E}$. and $\mathrm{I}_{77} \mathrm{~W}$. longitude. It consists of $x_{55}$ islands, with a total area of 7,400 square miles. Most of the land is contained in the two great islands of Viti Levu (Great Fiji) and Vanua Levu (Great Land), which account for 4, I I 2 and $2,43^{2}$ square miles respectively. These two islands are exceptionally well wooded and watered, and could, it is said, support three times the population of the whole 


\section{DESCRIPTIVE AND HUMOROUS}

group. Viti Levu is in every way the most important island in the archipelago. It contains the seat of government, the principal harbours, and all the roads, and much the greater part of the colony's trade. There is one town in the group besides Suva-Levuka, the capital of former days, on the small island of Ovalau.

The climate is certainly hot, though the thermometer does not rise to any extraordinary heights. During the three hottest months-January, February and Marchthe highest shade temperature ranges between $90^{\circ}$ and $94^{\circ} \mathrm{Fahr}$., and the lowest between $67^{\circ}$ and $72^{\circ}$, roughly speaking. In the cooler months of June, July and August, $59^{\circ}$ and $89^{\circ}$ are the usual extremes. The air is moist as a rule, and in Suva, at all events, one may safely say that a day without any rain is almost unknown. On the northern side of Viti Levu, the climate is a good deal drier, and in consequence less relaxing. Dysentery is fairly common, but there is no fever to speak of, and the climate, on the whole, is considered healthy. Mosquitoes are so troublesome that most of the better class private houses have at least one mosquito-proof room, with doors and windows protected by wire gauze.

One hears a good deal about hurricanes in Fiji, and the stranger might be pardoned for thinking that they are common features of the so-called "hurricane season." As a matter of fact, however, they are rare, many years often elapsing between one hurricane and the next. Between I 848 and I 90 I inclusive, there were only thirteen hurricanes in the group, and of these only six were really destructive. Most tropical climates would have a worse record to show if carefully investigated. Although the rainy months are damp and enervating, the drier half of the year, from April to October. is extremely pleasant, and not at all too hot. 
. . Not asleep yet? . . . The trade wind hums in the great vanes of the palm-trees outside the hotel veranda. It is very warm, and the flash of white foam on the barrier reef, between the flat tops of the quaint "rain-trees," and the red roofs of the lower town, is too far away to offer even a suggestion of coolness. Is it not too hot and drowsy a day to study Fijian geography and history?

No, for we are in the hot season, and every day for the next three months is going to be just like this, and if one only reads and works in a tropical climate when one feels like it, one will never get through any work at all. That is part of the "white man's burden," and pluckily he shoulders it as a rule. Most intellectual work in the hot season is done clear against the grain from beginning to end, after a fashion that would make the London city clerk stand aghast. Yet it is excellently done for the most part, and it does not, in Fiji, at all events, seem to tell against the health.

So, beginning as we mean to go on, we will look up the history books, and see what is the past record of this strange land into which we have come. We have already noted, passing down the street, the curious mixture of the population-whites, half-castes, Samoans, Indians, Chinese, and more conspicuous than any, the Fijians themselves, tall, magnificently built people of a colour between coffee and bronze, with stiff brush-like hair trained into a high "pompadour," clean shirts and smart short cotton kilts, and a general aspect of well-groomed neatness. They do not look at all like "savages," and again, they have not the keen, intellectual expression of the Indians, or the easy amiability of the Samoan type of countenance. They are partly Melanesian, partly Polynesian in type, and they form, it is quite evident, the 
connecting link between Eastern and Western Pacific. East of Fiji, life is one long lotus-eating dream, stirred only by occasional parties of pleasure, feasting, lovemaking, dancing, and a very little gardening work. Music is the soul of the people, beauty of face and movement is more the rule than the exception, and friendliness to strangers is carried almost to excess. Westward of the Fijis lie the dark, wicked cannibal groups of the Solomons, Banks, and New Hebrides, where life is more like a nightmare than a dream, murder stalks openly in broad daylight, the people are nearer to monkeys than to human beings in aspect, and music and dancing are little practised, and in the rudest possible state.

In Fiji itself, the nameless dreamy charm of the Eastern Islands is not; but the gloom, the fevers, the repulsive people of the West are absent also. Life is rather a serious matter for the Fijian on the whole; he is kept in order by his chiefs and by the British Government, and has to get through enough work in the year to pay his taxes; also, if the supply of volunteers runs short, he is liable to be forcibly recruited for the Armed Native Constabulary, and this is a fate that oppresses him a good deal-until he has accustomed himself to the discipline of the force, when he generally makes an excellent soldier. But all in all, he has a pleasant time, in a pleasant, productive climate, and is a very pleasant person himself, hospitable in the highest degree, honest, goodnatured, and clever with his hands, though of a less highly intellectual type than the Tongan or Samoan. Fijian solo dancing is not so good as that of the Eastern Pacific, but there is nothing in the whole South Seas to equal the magnificent tribe dancing of Vanua and Viti Levu, only seen at its best on the rare occasions of a great chief's wedding or funeral. The Waves of the Sea 
dance is one of the most celebrated; it is danced by several thousand men wearing long white streamers of tappa cloth (a native-made stuff beaten out of the inner bark of the mulberry-tree, and looking like fine white paper). These streamers, skilfully managed, suggest the crests of breaking rollers with extraordinary vividness, and the roaring song of the dancers closely reproduces the boom of the waves.

The history of the country goes back a very little way-only as far as 1643 , when Tasman discovered the group and named it Prince William Islands. He did not land, or make any explorations. Cook sailed within sight of Vatoa in 1773 , but did not visit any other of the islands. Bligh, after the mutiny of the Bounty, in I 789 , passed Moala during his wonderful boat voyage to Timor, and in 1792 returned in the Providence, and made some observations. In spite of these visits, however, and in spite of the fact that a number of Australian convicts escaped up to the islands about 1802, they remained almost unknown until D'Urville, in the Astrolabe, made a rather brief exploring tour in 1827 , and constructed the first chart. Captain Bethune in 1838 , the United States Exploring Expedition in 1840 , and a number of British vessels afterwards, completed the survey of the group. In 1835 the first missionaries arrived, and from this time onward the islands began to make progress toward civilisation. There is no need to repeat here the story of the cannibal days in Fiji, since mission literature has made this part of Fijian history famous all over the world-rather too much so, as the colonist of to-day declares. It takes a long time to uproot any fixed idea from the mind of the slow-going British public, and English people have not yet succeeded in realising that the cannibal and heathen days of Fiji passed away more than thirty years ago. To most of the home public, the 
Fijis are still the gloomy land of mission story, or else the "Cannibal Islands" of music-hall and nigger-minstrel humour-a place impossible to take seriously from any point of view, and certainly not a spot where any sane man would either travel for pleasure or emigrate for profit. Theirs is the loss, since the country is eminently adapted for both.

It is enough, then, to say that in the earlier part of the Nineteenth Century, the Fijian was the most determined cannibal known to savage history, and that murders of the white settlers and missionaries were frequent. By degrees, however, the untiring efforts of the missionaries, and the influence of the settlers themselves, few as they were, began to make an improvement, and in the early fifties the country was advancing rapidly toward a better state of civilisation, when the rise into power of the infamous King Thakombau, one of the worst monsters of cruelty known since the days of Nero, for a time held back the tide. Murders and massacres of the whites increased, war among the natives was continual, and there was small security for property. In 1855, however, came a serious check to Thakombau's power. The United States Government, incensed at the brutal murder of a number of shipwrecked sailors, demanded $£_{9,000}$ compensation, which the savage king found himself quite unable to pay. He offered to cede the islands to Great Britain in 1858 , on the condition that the indemnity should be taken over with the country and settled for him. England, as it happened, did not think that a fine colony right in the middle of the Pacific trade routes was worth buying at the cost of a decent countryhouse in the shires; so the offer was refused, and the richest prize in the South Seas went begging for more than sixteen years longer. 
The American Civil War proved the importance of Fiji's cotton industry, and was the cause of a sudden increase in the number of respectable settlers. Dangerous as the country still was, many families pluckily emigrated from Australia, took up waste lands, and began to make money rapidly. Some of them, it seems, thought that war and war prices would last for ever, since they lived splendidly on what they made, put down more and more cotton, and made no provision for the reaction that was bound to come. When it did arrive, many were ruined. Some left the colony, others lingered on, halfheartedly trying one kind of occupation after another, and failing in all. It is the remnant of these, and in many cases their children, who are the drag upon the wheel of the country to-day. They are the failure element, the unfit, the inefficient, and with the later importations of ne'er-do-wells, from which no colony is free, they make up an element of continual discontent and pessimism, not only discouraging to the enterprising new-comer, but actually hostile to him, in some cases, and bitterly envious of his progress.

The successes among the early emigrants, on the other hand, have in many cases done extremely well, acquired large properties, and formed the beginning of a native white population of the most desirable kind. Cotton-growing has long been dead in Fiji, but sugar, copra and other products have taken its place, and the children and grandchildren of the early settlers are in many cases quite as prosperous as their adventurous forefathers.

To return to the days of the American War and shortly after. A second check now came upon Thakombau's power. The warlike tribes of Tonga, a neighbouring group that had always been a rival of Fiji, began to 
give serious trouble. Maafu, a powerful chief, invaded the Fiji Islands, and it seemed as if a Tongan conquest were imminent. Thakombau, in alarm, called the whites to his aid, and arranged a constitutional government to support his waning power. It was to be carried out by white officials and ministers under himself as King, and would, he hoped, enable him to keep his country out of the hands of Tonga, without making any costly concessions.

The hope proved vain. After two years ( $187 \mathrm{I}$ to 1873), the mixed government broke down completely, and the King and his chiefs saw themselves confronted with a choice of two evils - to be conquered by Tonga, or to give up the country to Britain. They chose the latter, as the smaller evil, and in 1874 offered Fiji unconditionally to England.

England accepted the gift, and Fiji thenceforth became a Crown Colony. From 1874 onward there is little history to relate. History means trouble, and Fiji's troubles were over. Thakombau, retired on a good salary, and given enough royal honour to make him happy and content, ceased to annoy. He became a Christian, at all events nominally, and died, a good deal more peaceably than he deserved, in 1883 . The missionaries, Catholic and Protestant, had succeeded in Christianising the greater part of Fiji before the annexation, and the rest followed soon after. White settlers! increased, Indian labour was largely imported to work the plantations, as the natives of the islands did not care to engage; trade developed; a new town-Suva-was built, and took the place of the older chief town, Levuka, as capital of the group. A succession of British Governors, beginning with Sir Hercules Robinson, did their best to develop the country and improve the 
condition of the natives. In some cases their efforts were more well-meaning than wise, and left a melancholy legacy of mistakes for their successors to improve away, but, on the whole Fiji has been fortunate in her rulers.

The Governor of Fiji is also High Commissioner of the Western Pacific, holding jurisdiction over all British owned and protected groups in those seas, and also over British subjects living in groups owned by other countries, or not owned at all. These powers are by no means nominal; the position, indeed, is one of highest responsibility, and the cause of law and order in the islands generally has benefited much since the strong hand of British authority has extended its powers so far.

The Governor is assisted by an executive council of five, and a legislative council of twelve, six of whom are unofficial members elected by popular vote. The natives are governed through their chiefs, who are appointed by the Governor. There are several degrees of official chief, the smallest being the chief of a town called the Turango ni Koro. Over each district is a superior chief, with considerable power, called a Mbuli, and the whole country is divided into sixteen provinces, fourteen of which are ruled over by native chiefs who rank for the most part as princes, and are called "Roko Tui." The remaining two are under the control of British mayistrates. The chief of one province (Kandavu), is the grandson of Thakombau, and would be King of Fiji were the country not the property of Great Britain. He is quite contented, however, being very well off, and held in considerable honour by natives and whites. $\mathrm{He}$ is the only one of the chiefs who habitually wears European dress; the others preferring the national kilt or "sulu," worn with a shirt, and without shoes.

The present Governor, Sir Everard im Thurn, C.B., 
K.C.M.G., came into office in 1904. Although his time has been short, it has been long enough to prove that in him the islands have the ablest ruler they have yet enjoyed. Much has been done to improve the condition of the lower-class natives and repress the occasional exactions of the chiefs. Public works have been undertaken, obsolete laws removed, and representation in council granted to the planters. The vexatious ancient system of land-tenure, which was complicated and unsatisfactory, and a serious bar to settlement, has been reformed, and many minor improvements made, under circumstances difficult enough to excuse most rulers from attempting any reform at all. Fiji certainly owes much to Sir Everard im Thurn. Nor must the influence in the colony of Lady im Thurn pass without notice. There has never been a more popular governor's wife in Fiji than this exceptionally cultured and charming lady, who has so far identified herself with the interests of her South Sea home that she has even acquired the Fijian language, and speaks fluently to the native dignitaries in their own tongue when chiefs are entertained at Government House.

The decline of the native population is a matter that has occupied the attention of many governors, but so far it continues unchecked. It is not as serious as the fall that has taken place in the Cook Islands and other British dependencies, but nevertheless the numbers of the people, no matter what is done to ensure good hygiene in the villages, and to preserve infant life, fall by some hundreds every year. The Igor census gave the following result for the entire colony, including the outlying island of Rotumah: Europeans, 2549; half-castes, 1516; Indian coolies, $17, \mathrm{IO}_{5}$; islanders from other Pacific groups, I950; miscellaneous, 457; Fijians, 96,63 r. Total, I20, I28.

The reasons suggested for the decline are many- 
introduction of European diseases, increase of chest troubles owing to the wearing of clothes, over-indulgence in tobacco (especially in the case of nursing mothers), improper feeding of infants, \&c., \&c. No one, as a matter of fact, really knows why almost every Pacific race dies out by degrees through contact with the white, and certainly no one knows how to stop the decline. The causes do not lie so near the surface as might be supposed. Here and there, all over the Pacific, one meets with a stray island-sometimes part of a rapidly declining group -in which the population is more than holding its own, without any apparent reason. Niue is one example, Mangaia is another, and it has been claimed that the Tongan people are not diminishing, though -satisfactory proof of this is not at present to be had. In any case, Fiji is not among the lucky nations, and so far has the population declined even since the cannibal days, that large tracts of fertile land are lying waste and uninhabited in many parts of the group. Some of this is being taken up, with the assistance and encouragement of the Government, by those Indian coolies who do not take advantage of the free return passage at the end of the five years for which they are engaged to work in the plantations. The Indians make industrious cultivators and good subjects on the whole, and as they increase very rapidly, the time cannot be many generations removed when an Indian population will have replaced altogether the dying-out Fijian race. It may yet happen, however, that science will find some means of arresting the decay, and that one of the finest coloured races in the world will be saved from an extinction which every colonist and traveller would deeply regret. The Fijians themselves are, unfortunately, quite indifferent about the matter.

The trade of $\mathrm{Fiji}$ is by no means a negligible quantity. 


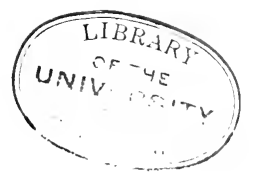




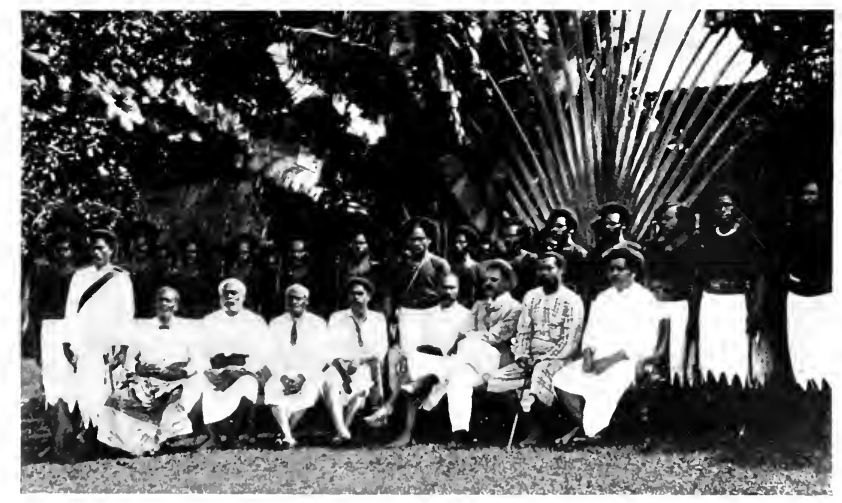

FIJIA CHIEF, ARMEI NATISE CONSTABLLARY BEHIND

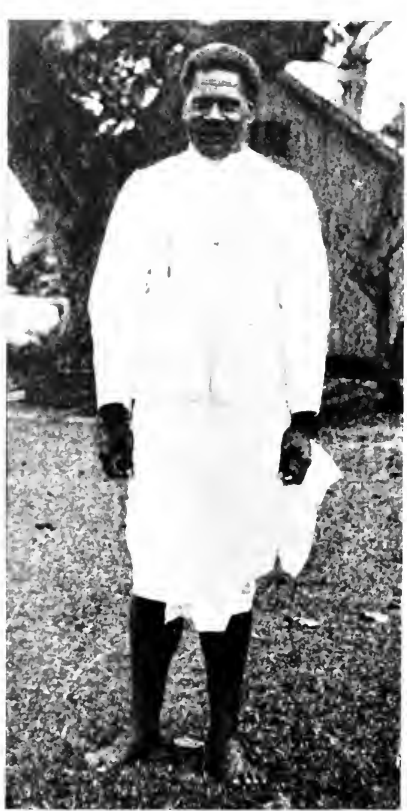

FIJIAN CHIEF

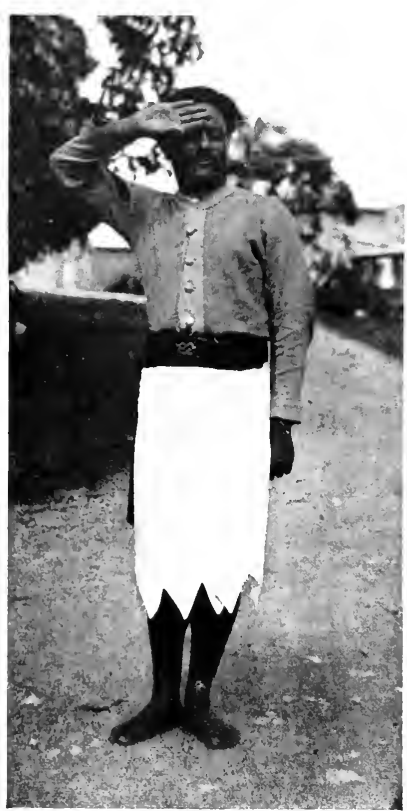

ARMEI NATIVE CONSTABULARY 
The value of the yearly exports amounts to well over half a million annually, and the imports are nearly as much. Sugar is the most important product. The Colonial Sugar Refining Company owns much of the good river-flat country, and employs quite an army of employees of all kinds, apart from the thousands of imported Indian labourers who cultivate the land. A good many independent planters cultivate cane for the company at a fixed price, and seem to do well on the proceeds. Bananas are largely grown, and exported for the most part to Australia. Peanuts have been tried lately, with some success. Tea and coffee are both grown, but do not usually attain to the best quality. Copra (the dried meat of the cocoanut) is a very important article of commerce, and many planters have done extremely well with it. Stock-raising is carried on with considerable success in Taviuni, about $\mathrm{Ba}$, and other parts of the colony. There are a number of minor industries and products which are still more or less on trial, among them vanilla and drugs of many kinds. The timber industry is important.

And now, having been serious for so long, we may look for a little amusement. We have not yet finished our study of Fijian social and economic conditions, but we can find all the humour we require without going outside it. Is there not the penal system still to consider? Certainly, at home, one does not look for delicate humour inside the walls of a jail, or expect practical jokes in the shape of a convict system. In topsy-turvy Fiji, however, the whole penal apparatus is one gigantic jest, and is regarded as such by most of the whites, and not a few of the natives.

To begin with, there is hardly any real crime, what there is being furnished chiefly by the Indian labourers 
employed on the estates of the Colonial Sugar Refining Company. The Fijians themselves, though less than two generations removed from the wild and wicked days of the Thakombau reign, are an extremely peaceable and good-natured set of people. In the fifties and sixties, and even later, murder, torture and cannibalism were the chief diversions of a Fijian's life, and the power of working onc's self into a more violent and unrestrained fit of rage than any one else of one's acquaintance was an elegant and much-sought-after accomplishment. This change, effected largely by the work of the missionaries, but also by the civilising influences of the British Government, and of planters and traders innumerable, is most notable. Nothing can be more amiable and good-natured than the Fijian of to-day; no coloured citizen in all the circle of the British Colonies is less inclined to crime. Yet the great jail in Suva, and the various smaller ones dotted about among the country police-stations, are always well filled; for the Fijian, being naturally rather thick-headed, manages, in spite of all his amiability, to run up against the British Constitution every now and then. There are laws for his guidance and restraint that do not exactly please him; and, as he cheerfully drives a coach-and-six, or its Fijian equivalent, right through them whenever he feels inclined, it follows that an interlude of jail is an extremely common incident in Fijian life.

"What are most of the prisoners in jail for?" I asked a government official one day.

"Saying 'Boo!' to a Buli," he replied; "that's about the commonest crime. You see, no Fijian is allowed to leave his village without the permission of the Buli, or chief of the district."

"What on earth for?"

"Well, the idea is that the village can't get on with- 


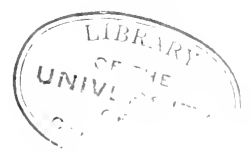




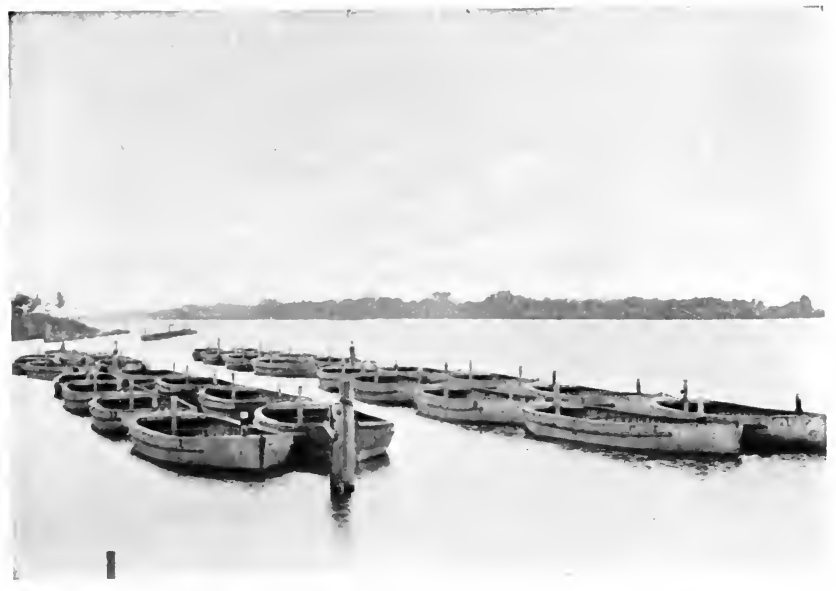

SUGAR BUATS, REIIA RIVER

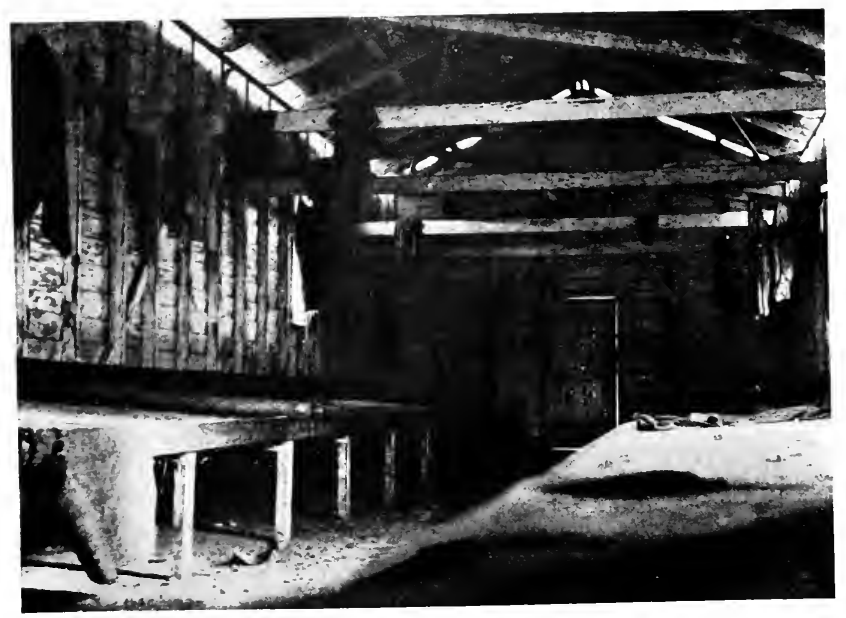

A FIJIAN JAIL 
out him. But sometimes he goes off without leave, and when the Buli sends for him to come back, he tells him to go and put his head in a bag-or words to that effect. So then the Buli has him arrested by the native police, and taken to Suva for trial and imprisonment. That is the law."

"Aren't there any other offences?"

"Oh, yes. Sometimes they don't pay their taxes, which have to be paid in kind, to encourage industry: so much tobacco, or maize, or timber, or what not. Then it's jail again. And sometimes they run away when they have entered into a contract to stay a certain time working at a special place. And just now and then-though very seldom-some man hits another over the head with a club for running away with his girl; so there's another case. One way and another, the jails are kept at work."

"Well, it seems to me cruel and tyrannical to make convicts of the poor Fijians for such trifles."

"Oh, is it? You wait and see!"

I did. I saw. And I felt, on the whole, that my sentimental pity was wasted.

The jail in Suva is a most imposing place. It presents a fine stone wall of considerable height to the view of the visitor coming up the road; and there is a great gate, and a small door to come in by, quite like a European jail. But when you have got inside, and begun to notice the buildings scattered about the courtyard-dormitories, solitary cells, cook-houses, and what not-it comes upon you with something of a shock that the imposing wall is nothing, after all, but a joke-one of the many jokes of the wonderful Fijian penal system. It extends round only three sides of the grounds, leaving the back completely open to the bush and the hills -as if the whole 
establishment were a toy to be set on the mantelshelf, and looked at only from the front.

"What on earth is that wall for?" I asked, in a state of stupefaction.

"To look pretty. Don't you think it looks pretty?" solicitously asked the friend who was accompanying me.

"Do they never run away?"

"Hardly ever, and if they do, they generally come back."

"Why do they stay, when they needn't?"

"Well, I think, because they rather like being in jail!"

This statement seemed almost too much to swallow at one time, but I found out afterward it was very near the truth. The Fijian attaches no disgrace whatever to being in jail; indeed, it would be hard for him to do so, since the larger proportion of his acquaintance have passed through that experience at one time or another. He regards it as a slight inconvenience; an interruption to his occupations at home, largely compensated, however, by the delights of a trip on a steamer down to Suva, and a sight of the busy capital. Furthermore, he is sure to find plenty of old friends in the jail, and they welcome him joyfully.

"A-wa-wé! Reubeni, is that you? Well, well, I'm glad to see you. Here, Wiliami, Lomai, Volavola! Here's Reubeni from Thakandrove! Come along, Reubeni, we're just going to supper. Why, you've come at a splendid time; most of us are gardening at the Kovana's (Governor's), and there's going to be a big festival in the grounds to-morrow, and a tug-of-war. You've never been to Suva, have you? No-well, it's a fine place, and very gay just now. I hope you'll enjoy your stay."

This, or something like it, spoken in Fijian, is the 
prisoner's welcome to the jail. He is lodged in a building fitted up with long shelves, on which he sleeps very comfortably, and is looked after by a warder belonging to the Armed Native Constabulary, who usually acts as a sort of general servant to the prisoners, preparing their food for them, and making himself universally handy. In the morning, refreshed and inspirited by a meal considerably better than anything he gets at home, the convict starts out with a group of friends, in charge of a warder, to the place where he is assigned to work. Probably he has been put on hard labour, but-unless there is any roadmaking or building to be done-the labour available is not very exhausting. The grass edgings and lawns of the town want a good deal of trimming, so the convict probably has a knife handed over to him, with a sharp, heavy blade, two feet long, and squats down on the grass by the border of the main street, to hack and trim at his ease all day. Perhaps his neighbour is a friend from home, sent to jail for breaking a labour contract; perhaps it is an Indian who has killed a Sugar Company overseer, and cut him into little bits. In any case, they squat side by side, dressed alike in neat shirts and "salus" of unbleached calico stamped over with broad arrows, working away in as leisurely a manner as possible, and thoroughly enjoying the gay sight presented by the busy main street. . . . There is a steamer in to-day; the pavement is dotted with tourists-British, American, Colonial-armed with guidebooks and cameras and the totally unnecessary pugaree that the travelling Briton loves to deck himself withal. The tourists look at the convicts and their knives apprehensively. Reubeni is a mountain lad, and his hair is very wild and long, and his teeth are big and sharp, and he looks cannibal every inch, though in reality he 
is as mild as milk, and the light of the local Sundayschool.

"James! James!" vociferates a lady tourist, fat and elderly and nervous. "Why did you not bring your revolver on shore with you, as I told you? I am sure these savages are most dangerous-and the road is literally full of convict murderers and thieves, all armed with daggers! Do let us go back to the steamer!"

But perhaps Reubeni has some other variety of "hard labour" assigned to him. The Government Office up on the hill-a great bee-hive of red-roofed buildings, full of rooms and "departments" - needs a good many messengers, and all day long one may see stalwart, jolly-looking Fijians in broad-arrowed suits loafing agreeably on the shady verandas, or strolling about the town, conveying letters to Government House, or the Commandant of the Forces, or the Club, or the Bank. Every letter means a pleasant "yarn" with the houseservants, and perhaps a lump of cold yam, or a bit of tinned meat, out of the kitchen, while the answer is being written. There may be money to send to, or from, the Bank, or from one department to another. The convict carries it, gets a receipt, and brings it back again. His acquaintances among the white people recognise him pleasantly as he passes.

"Well, Reubeni, you up here! What are you in for?"

"Not paying taxes, saka (sir)."

"That's very wicked of you: you won't go tc Heaven if you don't pay your taxes, you lazy beggar. Is this your first time?"

"Eo, saka (Yes, sir). I have never been in the King's service before." (Fijian term for being in jail). "How do you like it?"

"It is not a bad service, saka, we have plenty to eat." 
"Well, look me up when your time is out, if you'd like to engage in Suva; I want a house-boy."

"Savinaka, saka (Very good, sir). I will come; I think your service will be quite as good as the jail, saka."

One of the pet jokes of Suva is the home-going of Reubeni and his kind, every evening a little before six o'clock. The gates of the jail are closed at six, and a few minutes earlier gangs of prisoners can be seen collecting from every part of the town-some under the care of a warder, but many alone-all hurrying anxiously toward the jail. As the hour draws nearer, they hurry more and more, and many begin to run, with anxiety painted plain on their copper countenances. If they are not in at six o'clock, a terrible punishment awaits thema punishment they would do anything to avoid. Discipline must be kept up, and there is no mercy for the prisoner who neglects the closing hour.

What happens to him?

He is shut out of jail.

No supper for him -an unspeakable calamity thisno evening gossip, no bed Until to-morrow he is an outcast without a home. You may see him, perhaps, if you drive past the jail a little after sunset, crouching low on the threshold of the gateway, wiping his tearful eyes with the hem of his broad-arrowed "sulu," and presenting an excellent living picture of the famous line:

"Oh, who would inhabit this cold world alone?"

Poor Fijian!

I was staying with the resident magistrate in one of the Vanua Levu districts during my subsequent tour, and, hearing that there was a vanilla plantation some sight miles away, asked if I could go and see it. 
"Oh, certainly," said my host. "You can go on a truck down the company's tram-line-they allow all the white residents to use it-and I'll send a couple of convicts with you, as I can't go myself to-day!"

The convicts were produced-a pair of sleepy, wildhaired Fijians, in jail clothing-and the magistrate told them to push the truck for me down to the plantation, and wait till I came back to it.

"Savinaka, saka," they replied, saluting in military fashion, and off we set-myself in a kitchen chair perched somewhat perilously upon a flat, edgeless truck, the convicts standing one each side of me, also upon the truck, and "putting" it along with poles. They kept up an astonishing pace along the eight miles of line, being in excellent spirits over their job, which certainly was pleasanter than the monotonous rice-husking on which they had been at work. I should have preferred their being a little less happy, however, if it had made them a little less reckless, for they punted the.crazy vehicle along at fifteen miles an hour round every curve, and chanced the meeting or overtaking of anything else; the result of which was that, on one occasion, we swept round a corner "full bat" toward an advancing truck occupied by eight Indians going up to the settlement we had just left. It was a single line, and destruction seemed imminent; however, the Indians, seeing a "memsahib" on the truck that was roaring down upon them like a devouring lion, leaped wildly from their seats, and contrived by unearthly efforts to overset their own vehicle off the line into the ditch alongside, where it lay with its whirling wheels turned up to Heaven, looking extremely like a helpless, overturned beetle, as we rushed wildly past.

Arrived at the plantation, the convicts sat down on 
the truck, and feasted on biscuits and tinned salmon which I bought for them at the store (having been solemnly warned by the Government of Fiji not to dare to give them money). I spent an hour or two in the plantation, and returned when I was ready. The jailbirds, who could, of course, have run away a hundred times over if they had felt like it, were asleep in the shade, waiting my pleasure. We spun merrily home again, and at the foot of the hill leading to the house my two convicts delivered me back safely to my host, and I delivered them back to the same person. Whether they were in charge of me for the day, or I of them, is a problem that I have not yet been able to solve, even with the aid of mathematics, because, if things that are equal to the same thing are equal to one another, and if the convicts were equal to taking charge of me and I was equal to taking charge of them, then we were equal to each other-which means either that they were English lady travellers or that I was a Fijian convict; and both solutions seem unsatisfactory somehow.

One other form of hard labour inflicted on the Fijian convict is worth noting. The mails from Suva are frequently carried up-country, to distances of forty or fifty miles, by convict letter-carriers! They journey alone, always come back as nearly up to time as a Fijian can, and evidently see nothing anomalous in the fact of being thus made their own jailors.

One might have a worse billet, in a hard and mistrustful world, than that of a Fijian convict. 



\section{CHAPTER II}

\section{ON THE TRAIL}

Garden of the Swiss Family Robinson-Over the Hills and Far Away-The Pandanus Prairies-Fijian Luggage -The Curse of the Spotted Bun-A Tropical ForestBenighted on the Way

WHEN I had driven up to the top of the Flag-staff hill in Suva, gone to see the Botanic Gardens, boated up the Tamavua River, looked at Thakombau's monument, exhausted the attractions of the curio shops, and seen something of Suva society (which is tiresomely like society at home, though so hospitable and kindly that one must forgive it), somebody very kindly told me about the plantations on the other side of the harbour, and thereby started me on a quest after information spiced with amusement that lasted the better part of six months, and gave me what was, on the whole, the second-best, if not the best, time of all my life.

The sail over to the plantation was a journey of exquisite loveliness, for Suva Harbour is famous even among the countless beautiful harbours of the wonderful South Sea world. But it did not interest me very much on the return journey. I had been seeing and hearing things that made me think.

There seemed to be nothing that did not grow in the place I had been seeing. Unkindly discredit has been cast on the dear old "Swiss Family Robinson" and its remarkably catholic list of fauna and flora: vet it appeared to me, 
walking about the plantation-a mere private experiment, unsupported by much capital-that I had stepped right back into childhood and the pages of that marvellous book. Bananas, oranges and pine-apples were, of course, as common as dust. Allspice dangled on one green bough, fat red chillies on another. Turmeric, excellent for curries; fragrant limes, delicate vanilla, croton and castor oils, ramie fibre, erythroxylon coca (where the cocaine comes from), gum arabic, sisal hemp, cassia, teak, West India arrowroot, cloves, annatto, areca-nut palms, ginger, cocoa, papya, and a whole regiment of other useful or pleasant things, "flourished" (as the early Victorian novels used to say) "in the richest luxuriance." And all these plants, without exception, had been proved to do exceptionally well in Fiji. Many of them grew wild all over the country; others, imported (such as cocoa, allspice and vanilla), had produced seeds and beans of a quality surpassing anything else in the markets of the world. Withal, there were tens of thousands of acres all over the islands unused and unoccupied; white settlers and planters seldom or never came to try their luck, and the resources of this, the richest of all the rich Pacific archipelagoes, was not one-hundredth part developed.

As to the reason of this, Suva, the European capital, could offer me no suggestion, except the old, familiar statement that no one had ever tried these things, and, therefore, no one ever ought. A few Government officials, primed with figures that looked extremely useful, and, somehow, weren't, gave me quantities of information that left the matter just where it was before. It is a strange fact, and one I cannot explain, though I have often noted it, that Government information seems to lose much of its vitality in the canning process. It is like canned butter or meat correct in weight, good to 
look at, of excellent material, and yet, somehow, unsatisfying in the end.

So it came about that I made a resolve, and kept to it, in spite of the objections of Suva-Suva, which was clearly convinced, first, that I could not; secondly, that I ought not; and thirdly, that I should find it useless-to go through the interior of the islands myself and see just what the native and his life were like, and of what value the country still might be to possible settlers.

One or two white women, accompanied by Europeans, had seen a little of the native country in recent years; but none had gone very far, and certainly none had ever travelled alone, I was told. Were the natives cannibal now? Certainly not; cannibalism was as dead in the Fijis as painting with woad in England. Were they rude to strangers? By no means; they were the soul of hospitality. But the sum of objection remained the samethe objectors, who had never been ten miles from Suva themselves, maintaining that "it was too rough."

One can always find the man who really knows, if one takes time. I found him-a Government dignitary of brisk and authoritative presence, energetic to the ends of his smartly trained moustache, learned in the ways of wild countries, and (strange to say) knowing not a little of the country he was engaged in helping to govern. He did not feed me with statistics, but came down at once to fact.

"Rough? Yes, but not too much so," he said. "Certainly, go if you fancy it; you'll have a royal time. The natives are capital fellows; they'll make a queen of you everywhere you go, and you'll see some of the finest scenery in the world. Firearms? Well, you might as well have a Colt with you, as not; it's eas; tc carrybut you won't need it. . . . No trouble at all. 
Anything else that I can do? . . Well, good-bye, and good luck!"”

Then came the delightful preparations. I had never been "off the road" before, and everything that had to be bought was an added prophecy of enjoyment. The side-saddle, the leather saddle-bags for small articles, the minute steel trunk, two feet by one, for all my clothes; the mosquito-net and oilcloth-covered pillow, the tin billy for tea-making, tin cups and saucers, common knife and fork and spoon, common canvas shoes for rough walking, parcels of ship's biscuits, tinned meat, tea and sugar and salt-all spoke eloquently of freedom, and the "call of the road," and long, bright days under the open sky. And when I had engaged a time-expired native soldier of the Governor's armed constabulary force to act as interpreter and courier, and picked up a couple of carriers at $\mathrm{Ba}$, the "jumping-off place" into the unknown, I was absolutely inflated with pride, and felt that Stanley, Burton and Speke were not to be named with myself.

It would, of course, have been possible to walk throughout the trip. But Fiji lies between the fifteenth and twenty-first parallels of south latitude, and its hot season is no trifle. By riding, I could cover twenty to thirty miles daily of rough mountain bridle-tracks (there being no roads in the interior) without suffering from the heat, or feeling any fatigue, whereas the same amount of walking, in a tropical climate, would have been tiring and extremely hot. As for the men, forty miles a day would not have exceeded their powers; they were always on the heels of my horse, burdened though they were; and they travelled with a long, slow, wolf-like stride that never slacked or altered, up hill or down, no matter what the heat might be, or how sharply the rough track inclined.

$\mathrm{Ba}$, the last fortress of civilisation on the northern 


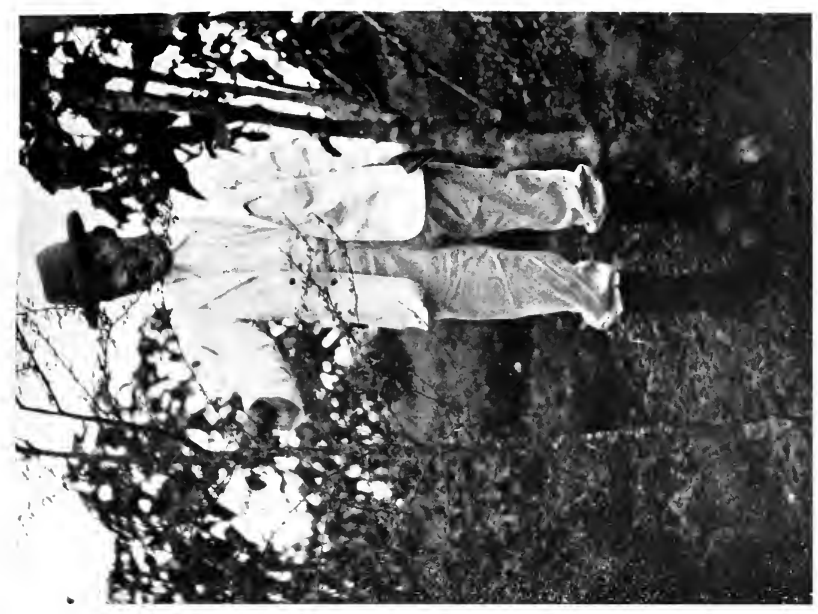

高

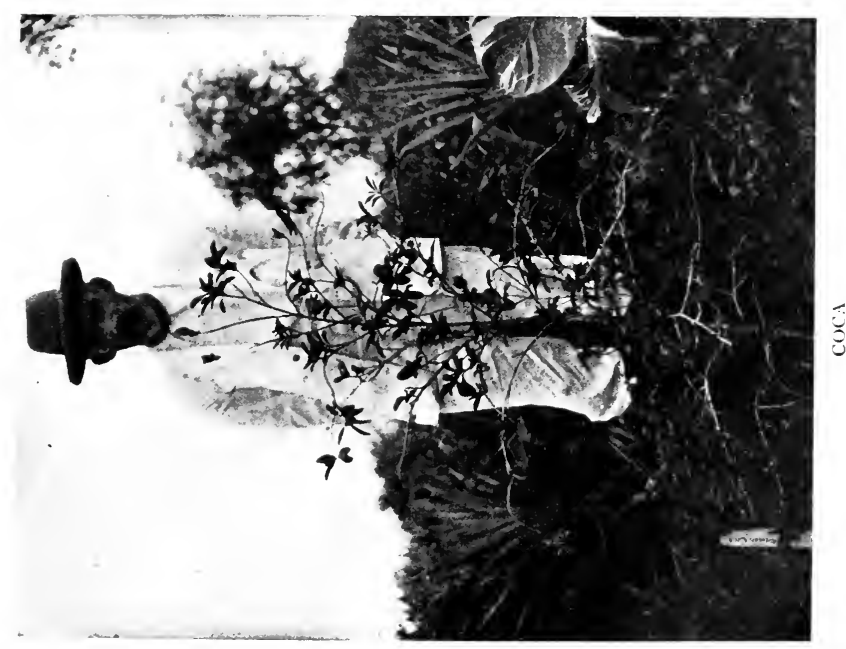


side of the great highland region I was to cross, is a halfFijian, half-European town; very hot in the burning days of March, very much plagued with flies, fairly pretty, and inordinately devoted to the interests of the great Sugar Company. There is no escaping the Colonial Sugar Refining Company in Fiji, save in the far interior. Thousands of acres are covered with the beautiful verdigrisgreen of the growing canes; hundreds of the white population are employed as overseers, mechanics, clerks and managers on the various estates, while, as for the Indian, Polynesian and Fijian labourers, they form a very large item indeed in the census returns of the islands. I have not the least doubt that the original pioneers of this enormously wealthy company were met with exactly the same cold-water-bucket comments and remonstrances as the smaller would-be planters of to-day. The "oldest inhabitant" (who is just as unbearable a nuisance in Fiji as in any English shire) must certainly have told them that sugar had never been grown in the Fijis, therefore never could be; that the cotton industry had failed because of the close of the American Civil War, and, on that account, all planters who planted anything would certainly be ruined; and that there was no possible market for sugar, if they did succeed in growing it. Also, that the oldest inhabitant had lived $x$ years in Fiji, and you couldn't teach him anything (which was painfully true).

The "C. S. R." has drawn its hundreds of thousands out of Fiji for many years now; but the oldest inhabitant is not a whit abashed. He had been rampant in Suva; he was genuinely distressed at my leaving $\mathrm{Ba}$ for the mountains. There was only wild bush and barren rock there, he said; I had better go back to Suva and take drives along the Rewa Road, if I wanted to be amused. 
But what mattered the oldest inhabitant, or anyone else, to me, that splendid morning when I started off with my three Fijians and the good Australian horse that a kindly resident had lent me, toward the lonely country of the brown men and women, away from white faces and white folk's unnecessary luxuries, into the wilds at last?

These first times! how one turns back to them again and again with a glow of kindly remembrance, in the hours when memory sits idle, feeding upon the honeycomb of stored-up delights! The first day in a foreign port with its strange brilliancy of light and colour, and music of Southern tongues-never so bright, never so musical again - the first night in the tropics under the silvered palms and the purple, warm-breasted sky-above all, the first day in the real wilds, alone with flowers of an alien race, whose presence scarcely breaks the solitude; the whole responsibility of the expedition lying upon one's own single pair of shoulders and the certainty of new experiences, adventures, perhaps even dangers, making strange music upon chords that have lain untouched through all a lifetime-such first times possess a freshness and a keen delight of their own, as perfect as first love itself.

The weather was faultless, although the sun beat hotly on the unprotected track. Fiji has one of the few really satisfactory tropical climates of the world. Its hot season is never too hot to allow of travelling in the middle of the day, and its cool season is no warmer than an English summer. It is true that in February, the month when I commenced my travels, the power of the sun is almost alarming; but sunstroke is practically unknown in the islands, and I rode all day with perfect safety, protecting myself from the scorching rays by a grass hat and a holland coat, worn over my thin cotton blouse. This is 


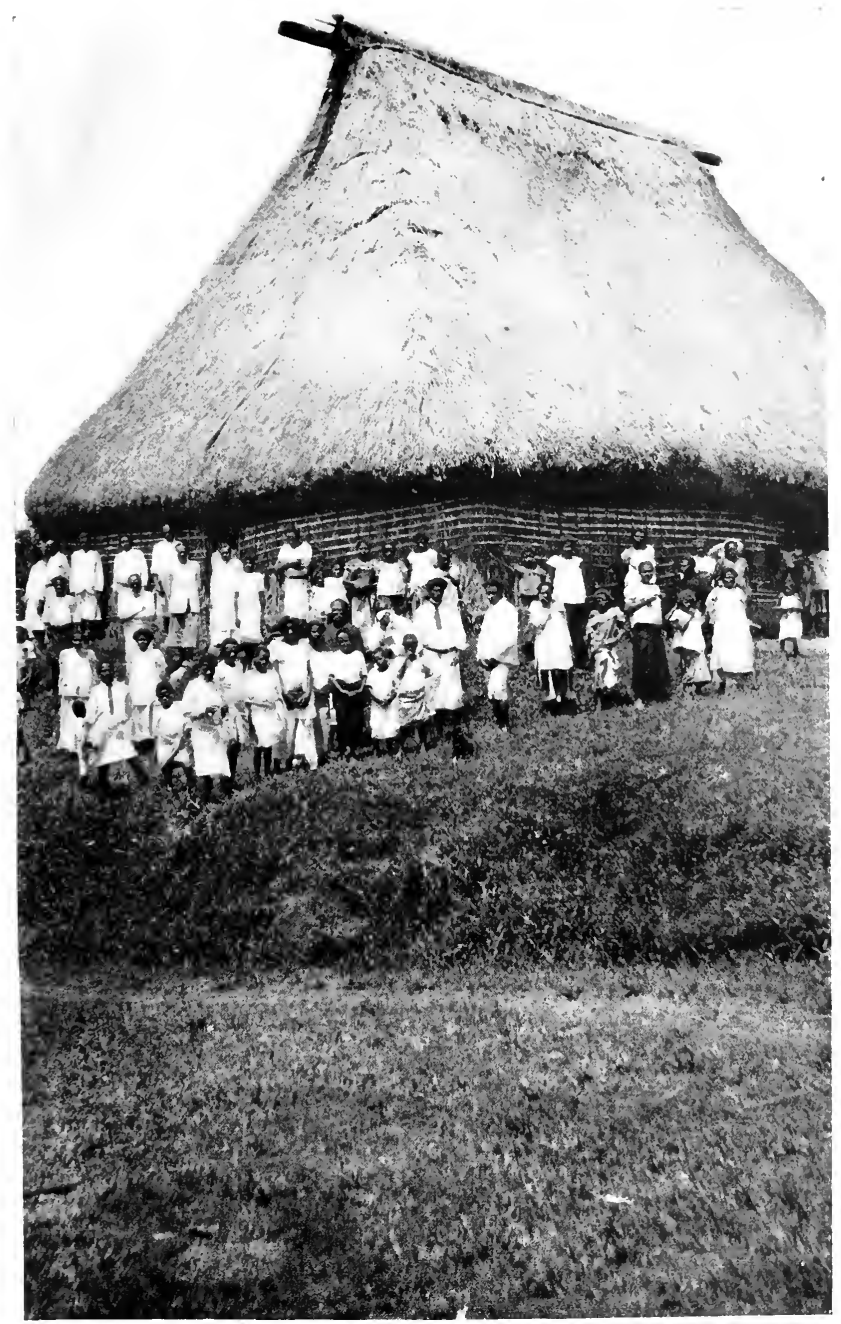

A Mountain house 


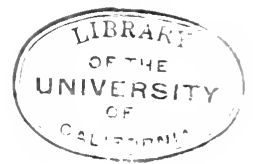


quite necessary for riding in the hot season; without a coat, one feels as though the flesh of one's neck, arms and shoulders would soon begin to crackle and cook.

But the molten-gold glory of the searching sun at high noon-the minute, photographic clearness of the "thousand shadowy pencilled valleys" on the far horizon hills-the fulness of light and life poured out by those blinding rays that strike down through the slender bush foliage as through glass, and bleach the very colour out of the shadeless, quivering sky-these things, to the traveller from the dim gray north, are worth all the heat and glare, destruction of hands and skin, that must be encountered. Enough sun, enough light, a royal profusion of God's most glorious gift; clear air like crystal; a far-reaching sweep of silent, sunny prairie-land; the warm wind in the feathered guinea-grass; the long, unknown track winding ahead into the heart of wild, battlemented, purple hills - this was the beginning of my hundred miles' march through the great island. A happy augury of happy days to come.

There is nothing under the northern star quite so quaint, so weird and witch-like, as the pandanus prairies of Fiji. The pandanus, or screw-pine, is an unnaturallooking plant at the best, even when young and tender. It begins its life in a most extraordinary screw-like shape, looking much as though some malicious hand had seized its long sword-like leaves, and twisted them round and round. Later, it straightens out, and grows a number of tall wooden stilts, on which it stands, firmly supported in all directions. Its foliage now consists of a number of drooping mops, inexpressibly mournful and depressed-looking. Among these mops hangs the fruit, very like a pine-apple, but not eatable (for Europeans), being made up of a number of hard red and yellow kernels, 
woody and fibrous in structure. It is, all in all, a most decadent-looking thing, strongly suggestive of the eighteen-nineties and Aubrey Beardsley-who, it is true, did not know or draw the pandanus, but who certainly ought to have been acquainted with such a kindred spirit of the vegetable kingdom.

All the hot morning I rode over rolling uplands of pandanus prairie, the air growing cooler as the heights increased, the threatening, dark hill-ranges still barring the sky in front. The men, striding tirelessly along in the rear, caught up with the horse every time I stopped to walk. They were a dandy trio, my three Fiji-men: neatly dressed in white singlets and coloured cashmere "sulus" finished off with a smart leather belt; their hair trained, clipped and oiled with the greatest care, and their personal luggage tidily packed away in Fijian trunks. A Fijian trunk is quite a curiosity in its way. It consists simply of an oblong kerosene tin, about eighteen inches by ten, cut in half lengthwise and the halves fitted over each other after the fashion of those Japanese travelling baskets that have become so common of late years. Inside, the Fijian carries his clothes, his "sulus" (a "sulu" is a piece of stuff two yards square, doubled and fastened round the loins to form a kilt) of cotton, cashmere, or flannel; his spare shirt or singlet, his bottle of cocoanut oil, looking-glass and wooden comk, with teeth six inches long, his tobacco, and all the rest of his personal property of every kind. Contact with the white man has not driven out the stolid common sense of the Fiji-man, so far as to induce him to burden his life with unnecessary possessions. Your carrier is provided for six months with the contents of that little tin. He will always have clean clothes and a smartly dressed head out of its minute store of goods; and, as for other wants, 
the ever-ready bush and river supply them. A razor? He will shave himself so clean with a chip of broken glass, or a piece of shell, that you doubt his ever having had a beard. A sponge? soap? tooth-brush? Green cocoanuts supply him with an oily, juicy husk that does the work of the first two, and as for the third, he rinses his mouth after eating, and that is enough to keep his magnificent teeth in repair, even if he does put them to uses (such as tearing open tins that resist the tin-opener, and husking cocoanuts) that make the white man's grinders shiver sympathetically in their sockets. He does not wear shoes, even in the fullest of full dress, and the only use for a pocket-handkerchief that he knows is to stick it in the front of his singlet, for style. He wears a night-cap - that is, a deep band of stuff intended to keep his marvellous hair erect-but any banana-tree supplies him with that. So finely has he cut down the superfluities of life, that he does not even possess an inch of cotton stuff to tie up a chance cut with. A bit of dried leaf, neatly tied on with banana fibre, will serve instead. With the inexhaustible bush to draw from, he is never at a loss.

About midday I felt hungry, and called a halt. Gideon, my personal servant and interpreter, came up for orders. There was a nice, shady little spot under a big rock, and it seemed an excellent place to boil the kettle; so I told him I would have some tea.

A Fijian's face is as plain a mirror of passing thoughts as a child s. Gideon's dark countenance expressed something like respectful scorn, if such an emotion were possible, as he replied briefly:

"No water stop."

I felt first cousin to a fool, as I shook my horse into a canter again. No water! The habits of the 
hotel-living tourist had not yet been fairly shed. How could I expect taps and filters on the Naloto Range?

Yet there was something curiously pleasant that day, and many days after, in the dependence on Nature herself that was involved in just such delays and searchings. No water for the children till Mother gave it; no lemonade, till Mother threw a dozen great, gold citrons or lemons out of her storehouse into their hands; no rope to tie up the bundles, if Mother's store of slender tough lianas was not at hand; no lantern for the dark, if she had not lit up the moon in time.

I was meditating thus, on the bank of a glassy little stream, half an hour later, when the boys discovered that nobody had got any matches for the fire; and down I came with a run. I did not feel like Stanley now. Stanley would certainly have remembered the matches, nor would he have forgotten to carry water, even if he had omitted from his outfit the bag of spotted buns with which the last trader I had visited had successfully tempted me. I did not feel that I ought to have had those buns. It was not like an explorer; it was sure to bring bad luck. And now there were no matches.

But Joni had got astride a bamboo that was lying on the ground, and begun hacking at it with his knife, carving a small, deep groove in its flinty surface, and carefully shaping a splinter he had cut off from one of the broken ends. Now Nasoni seated himself opposite, and held down the bamboo with all his weight, while Joni rubbed the end of the splinter violently up and down in the groove. The exertion was great, and he panted as he worked; but it was several minutes before a little spire of smoke rose up from the groove, followed, shortly after, by just a tiny petal of orange flame. Nasoni was ready at once with a bit of crackling dried leaf; and 


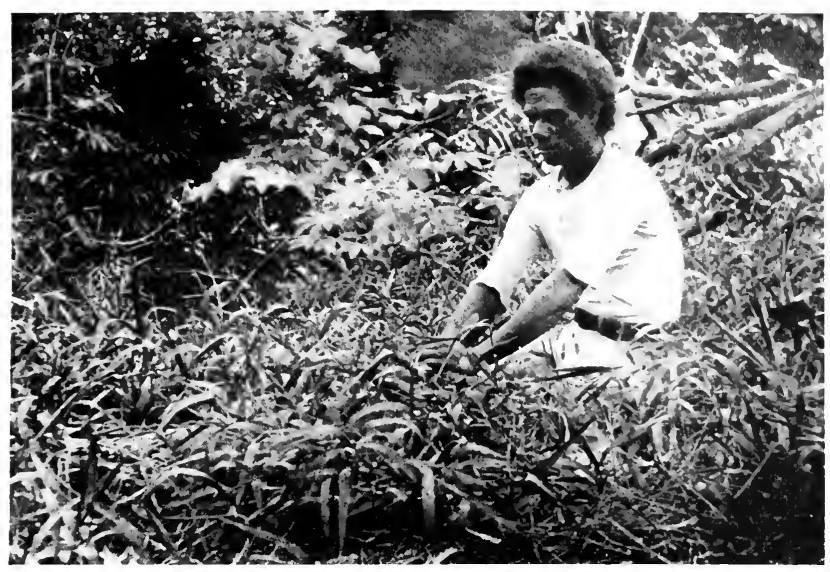

IONI MAKING FIRE

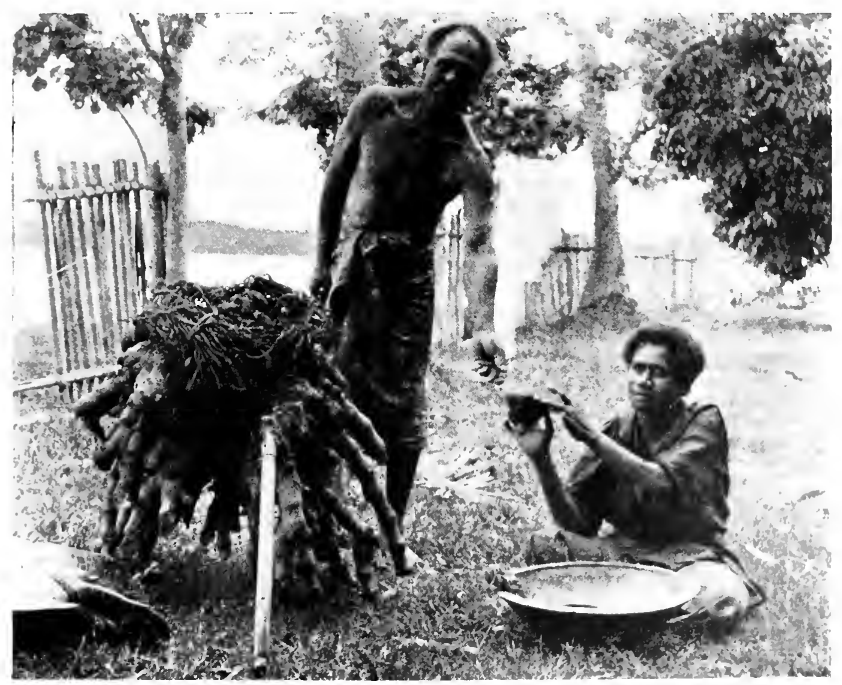

A ROOT OF YANGGUNA 


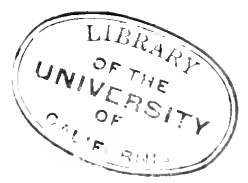


in another twenty seconds the fire was blazing and the billy was on, while the boys relaxed after their efforts, and tumbled themselves down in the grass, in dislocated heaps of happy laziness.

So I had really seen the famous South Sea method of making fire by rubbing two sticks together! I had always been rather sceptical about it, at best, and certainly did not expect to see a Twentieth-Century Fijian, who dressed in "store" cotton stuffs, and went to church five times on a Sunday, performing this famous savage feat. It was my first example of a truth most thoroughly rubbed in by subsequent events, that the Fijian's civilisation is only varnish-deep. Cannibalism has been abandoned, cruelty and torture given up, an ample amount of clothing universally adopted, yet the Fijian of to-day, freed from the white control and example that have moulded all his life, would spring back like an unstrung bow to the thoughts and ways of his fathers. This is a truth doubted by no man who knows the inner life of Fiji.

Taking things easily, and not at all troubled by the fact that I was not "making good time" (that malignant fetish of the average traveller), I found myself, in the afternoon, well up the slopes of the Naloto Range, and entering the forest. For the best part of ten miles I had ridden through land that was absolutely deserted; land where the great, rolling prairies stretched like a pale-green sea to right and left, unbroken save by the melancholy mop-headed ghosts of the pandanus-tree. There were no towns or houses, not so much as a stray native padding along the track, or a patch of yam- or taro-land, to show that the country was of use to some one. And all the earth was thickly clothed with dense, rich, reedy grass, six to ten feet high, excellent food for 
horses, cattle or sheep-and every mile or two, tinkling streams, or deep-voiced torrents, furrowed the heart of the valleys. Twelve miles away there was a port with calling steamers; three days' sail distant lay the great, barren, populous land of New Caledonia, ready to take any meat that fertile Fiji could send. Already, nearer to $\mathrm{Ba}$, more than one man had braved the scorn of the oldest inhabitant by raising cattle for Fiji itself, and accumulating a comfortable fortune. Why should these great wastes of grass lie idle? The native owner's, I knew, were ready to let, and had given good grazing land as low as a shilling an acre; there was no clearing required, and no difficulty in driving stock to market. Why should not-

Gideon, who began to find the day wearisome, if not tiring, here broke in on the current of my reflections by gathering and presenting a splendid pink orchid, perfumed with a scent of such exquisite novelty and delicacy that I could not make up my mind to throw it away, even when it got in the way of my whip and reins. There were large numbers of these about the edges of the track. I could not, however, help sneering conceitedly, as the afternoon wore on, at the want of accuracy displayed by most travellers, in describing a tropical forest. The "blaze of flowers" so often spoken of is not a feature of the usual tropical bush. Every variety of green is there, in choking, strangling luxuriance-exquisite tree-ferns like great, green, lace parasols blown inside out; huge, handsome trees with big, varnished leaves, or dangling pale-green tassels a yard long; tall shaddocks, casting down things that looked like oranges ten inches in diameter, and were only a bitter delusion, nearly all rind; a rare citron-tree or two, with rough-rinded yellow fruit; numbers of pretty shrubs and bushes; and-tangled 
through and round and under and over everythinglianas thick and thin, brown and green, running like the cordage of some gigantic sailing-ship from airy heights right down to the ground. This was the forest. True, there were flowers-one big tree was starred with waxywhite, perfumed tuberoses; a handsome bush had blossoms like a pink-and-white azalea; another bloomed like a meadow buttercup; scarlet salvia lit flames in dim green corners, and an exquisite lilac-flowered creeper tangled itself about the borders of the track.

But all these were swallowed up, as it were, in the overflowing life of leaf and tree, which shut out so much of the burning sun above that we tramped along in a cool green gloom. Why must the globe-trotter belittle the very real beauty of these tropic jungles by plastering it over with his own sensational falsehoods? It is lovely enough, in all conscience without the non-existent "blaze of flowers."

I was not the first to make this observation, as I found when I returned to Suva, and read the fascinating book of South American travel written by His Excellency the Governor of Fiji, Sir Everard im Thurn, C.B., K.C.M.G. I fear I quoted the classical curse about the people who capture our pet ideas before we secure them ourselves, when I found my remarks anticipated in this manner. However, the truth is a truth; let it stand.

For an hour or two the track was now so steep that I had to walk, letting the horse scramble after me as best he could. Then, when the sun was already setting (for I had delayed a long time on the way, gathering flowers and photographing), we came out into a narrow gap that framed in a minature picture of half the island of Viti Levu, or so it seemed. Here was the summit of the 3,00o-foot range, and somewhere in those wild, 
barren hills below we must find shelter for the night, since there was now no chance of reaching the town of Nambukuya that day.

The men told me that there was a small villageNandrunga-within a couple of miles; and toward this we made, scrambling and clattering madly down the mountain side, to cheat the growing dark. The black, monstrous peaks gloomed about us, sinister, strange and evil in the gray-green dusk; the ten-foot reed-grass waved its melancholy heads above us like funeral plumes; my three wild-eyed Fijians tramped silently in the rear. Among these very peaks, and in this valley that we were traversing, countless murders and ambushes had taken place, and cannibal feasts been held, in the stormy seventies. I was going to sleep in a native village, far from any white people; I could speak hardly anything of the language, and no white woman had ever before ventured through these regions alone-indeed (so far as I know), I was the first white woman who had ever travelled through these mountains under any circumstances. All this, in the uncanny dusk, among these wicked hills, fell rather coldly upon my heart; and I resolved to sleep with my revolver under my head, when rest and shelter should at last be reached. . . . It was absurd, dear reader, but I did not know it then. 


\section{CHAPTER III}

\section{NATIVE FOOD-A FIJIAN HOME}

Night in a Fijian House-A Colossal Bed-The City of a Dream-A Fascinating Fijian-How to Drink Yanggona-Wanted, a Stanley-Where are the Settlers?The Fairy Fortress

I THE pitch dark, we forded a river, allowing the 1 horse to find his own way in and out, and at last came up to a five-foot high palisade of thick bamboos, surrounding a cluster of dim, tall objects that looked more like haystacks than anything else. My men lowered the bars of a gate, and I rode into the village. All was dark and silent, but the men soon routed out the inhabitants of the biggest house, ran and looked for a light, and succeeded in finding a ship's lantern. This they lit, and then proceeded unceremoniously to take possession of the house, lighting a fire in the small square fire-pit near the door, "shooing" the sleepers out from under their mats on the floor, and depositing my various packages in convenient places. The inhabitants took all this quite as a matter of course, merely asking (or so I judged), who the marvellous apparition might be, and then squatting down outside the doorways to stare their fill, in stolid amazement.

While the men were making tea, and opening a tin of meat, I looked about me with interest, examing my quarters. The house was about thirty feet by fifteen or twenty. There was only one room. The roof was very 
high, and supported by a central post cut from a big bread-fruit tree. All round the walls were pillars, or, rather, pilasters, of similar wood, about four feet apart. The rafters were of bamboo, the ridge-poie of bread-fruit. Between the pillars of the walls was fine tapestry-work of reeds, which were laced together with black and red sinnet (cocoanut fibre) woven in pretty patterns. The floor was covered with a neat parquet of interlaced slips of bamboo, hidden here and there by the sleeping-mats of fine plaited rush or pandanus. There were three doors, one in the gable end, and one at each side, but no windows. I had been careful to enter by the side door, being warned by Gideon not on any account to go through the end door, which was for him and other kaisi (commoners), the side door being reserved for chiefs. The outside of the house, as I saw it next morning, was very neatly covered with reed-work, the roof being deeply thatched with dried grass. Like all mountain houses, it stood on an earthen platform about four feet high, faced with stones, and surrounded by a shallow ditch. Cocoanut logs, slightly notched, formed the only means of ascent to the doors. Not a nail was used in the whole building, everything being laced and tied together with sinnet.

Now some of the natives entered by the end door, carrying small plaited cocoanut-leaf mats, on which lay green banana-leaf platters full of baked yam. These they placed at my feet, bowing low as they did so. I was glad of the yams, for I knew by experience in other islands what a satisfying food these crisp white tubers make, and the mountain air had made us all hungry. The natives and my men sat at a distance, watching me eat, till I had done, and then divided the remains of the yam, also of my tinned meat and tea, among themselves. 
Scrupulously just and generous they were over these fragments of rare luxury, although the Fijian loves tinned meat and tea as his own soul. One man would take a bite off a small piece, then hand it on to the next; the recipient would have a bite in his turn, and immediately, with watering mouth, give the delicious morsel to someone else, and so it circulated till finished.

It was nearly time for bed now, so my men put up my mosquito-net on the bedplace, and told the Nandrungians that only the women might remain in the house for the night. This evidently impressed the Fijians as the funniest idea they had ever struck; the men cackled with laughter at the notion of anyone's objecting to sleep in a miscellaneous crowd of both sexes, while the women crowed with triumph at having the wonderful marama (lady) all to themselves. It is not often that a Fijian woman gets a chance of making herself prominent or getting the best of anything; she is simply a drudge and a slave, as a rule, eating the leavings of the men, doing all the hardest work, and pushed into a corner at once, if such a rarity as a white visitor passes through, because it is not modest for her to talk to, or even look at, strange men, also because she is a dog, a slave, and does not count. Now, the tables were turned, and the utter delight with which the women cleared the house, and ran about waiting on me after the men were gone, was something worth seeing. They screamed when I began to comb my hair, which was certainly unlike their own short stiff brush, and remarked, in a flattering tone, that it resembled the tail of a horse! They went into hysterics of joy over all my clothes, uttered strange savage "tck-tcks" of wonder at the riding-gloves I hung up to dry, and told each other that the marama wore "tarowis" on her hands, a word that 
I could easily translate without a dictionary. One young woman, shoebrush-haired, wild-eyed, and long of tooth, caressed my arm in a passion of delight, even going so far as to set her teeth gently in the flesh, and exclaim longingly, "Vinaka na kakana!" (What good food!) I knew that she was too young to have been a cannibal, and that her exclamation was only a compliment-somewhat left-handed, it is true-to my British skin; but the remark was interesting as an unconscious outbreak of heredity. The young lady's parents, a fine old couple residing in the next house, had, without any doubt at all, enjoyed many a hearty meal of human limbs, in the good old days, when the forearm was always considered the choicest and tenderest bit.

A Fijian bed is a curious resting-place, but not uncomfortable to a tired traveller. It is an immense platform, about three feet high, occupying the whole end of the house, and covered with six or eight layers of clean, cream-coloured mats, edged with tufts of red and blue wool. The foundation is made by screwing a tig log across the end of the room, and filling up the enclosed space with close-packed grass and fern. Pillows, made of a short section of bamboo trunk, lie about the platform; the Fijians place them under their necks, Japanese fashion, and protect their wonderful heads of hair from disturbance. Fortunately for comfort, I had my own travelling-cushion.

The women lay on the floor, and I slept well on the big bedplace, although I felt very much as if I had strayed into the Great Bed of Ware, and was in danger of losing myself, and although rats, cats, bat and scut, tering crawlies suggestive of centipedes created a sound of revelry by night all over the excellent ballroom floor furnished by the dais, until six o'clock thrust gray fingers 


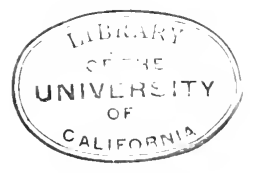




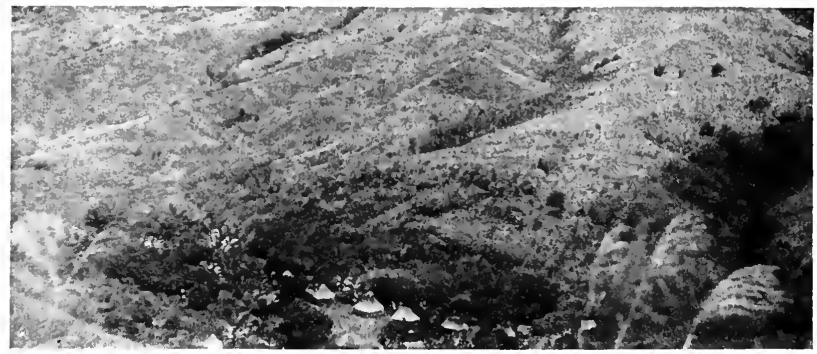

TINY TAMBALE

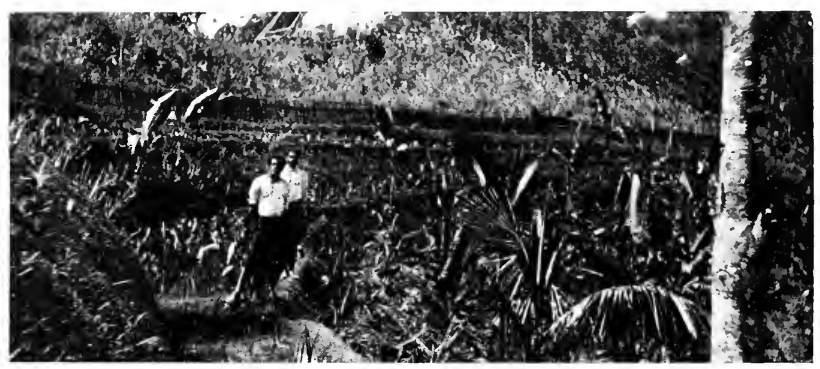

THE NDALO BEDS

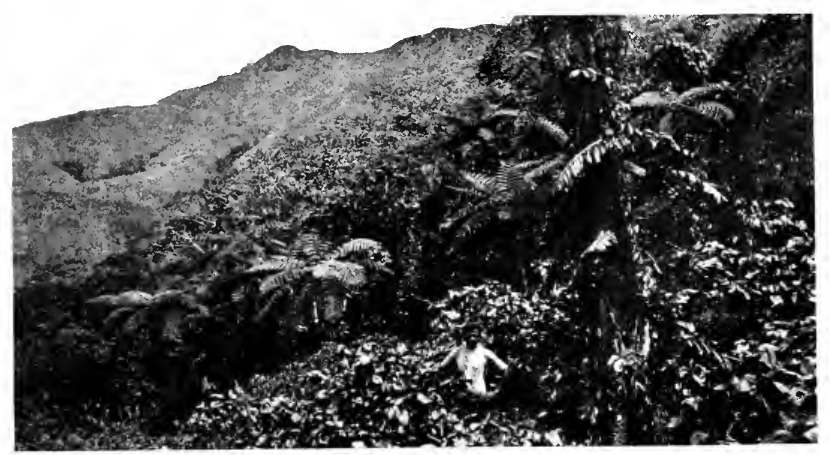

YANGGONA BUSHES 
under the narrow doors, and waked me up. The women, still exulting in their triumph, escorted me down to the river, and showed me a deep, cool hole to bathe in. While I enjoyed a dip, they sat on the bank and slapped their hands on the rocks, beating time to a strange, humming, monotonous chorus in which they sang of my many wonders and virtues. These impromptu addresses in verse are very common in Fiji, and men and women alike are most skilful in improvisation. It was rather a novelty to take one's morning tub to the sound of a hymn eulogising one's clothes, remote ancestors, rich possessions of tinned meats and biscuits, and gorgeous Turkey-cotton swimming-dress; but a tour through the Fijis is one continual succession of humorous novelties, and one soon gets used to them.

The little village looked indescribably quaint and pretty in the slanting rays of the early sun. It numbered only about a dozen houses, clustered on their tidy little green, like toys on a table. The curious stands on which most Fijian mountain houses are perched added to the toy-like appearance, and the immense beehive roofs of the older buildings stood up among the delicate young palms with the odd, almost sinister effect that is a feature of all these lovely hill fortresses. A strange mixture of opposing qualities, truly.

Everything was odd and new-the scanty sulus of the men and women, worn without upper clothing, for the most part; the long bamboos that stood in every house, to hold water, all the joints except the bottom one being skilfully pierced, so as to create a very useful water-vessel; the big, frizzled head-dresses of the men, so much larger than the neat, small coiffures popular in the coast towns below. The Fijian of to-day seldom or never dresses his hair in the enormous mop of ancient 
times, for the early missionaries insisted that all their converts should show their abandonment of heathen ways by cutting their locks. Still, the hair of these islanders is so extraordinarily thick, stiff and wiry, that it can hardly be dressed after any European fashion, and many heads may be seen in the mountains which, uncultivated and undressed, save for the popular bleaching with lime to a yellow tint, display a ragged halo standing loosely out for at least a foot round the face.

The Fijian who is careful of his hair-and most are -does not allow it to run wild like this. It is his chief object in life, first, to train his stiff locks to stand on end, and secondly, to cut and trim them into the neatest possible busby, some six inches high. At night, and when en déshabillé, he wears a compressing band, as religiously as an East End coster-girl wears her curlingpins. When the hair is long and erect enough, he takes a looking-glass and scissors, gives the latter to a friend, and holds the former himself, critically observing the friend as he clips and shapes the dense bush with wonderful skill. There are fashions in Fijian hair-dressing; at present, the favourite mode is to shape the hair off the forehead in a deep, slightly overhanging bevel, curved sharply outward at the temples so as to make a bush at each side of the head. The rest of the hair is rounded off so neatly that it looks like a block of black or yellow wood, several inches deep. Cocoanut oil, scented with flowers, is freely used, and the men constantly decorate their heads by sticking scarlet or white flowers into them, exactly as one sticks pins into a pincushion. I may here observe that Nasoni, anxious to make an impression on the hearts of the country maidens, turned up for the start that morning with his mahogany bush of hair adorned with two kinds of red flowers, three 
kinds of white, a bunch of green-and-white ribbon-grass, and an aigrette of fern! It rained a little after we started, but Nasoni protected his elegant coiffure with a giant taro-leaf, some four feet by three, held up umbrella-wise by the stalk, and did not get a drop.

The rain cleared off soon, and we covered some sixteen miles by afternoon, journeying for the most part along the crests of narrow ridges, surrounded by a sea of the most magnificent hill scenery in all Fiji. Never before had I witnessed the solid lap of Mother Earth tossed up into such a strange tumult as this. The wornout term "rolling mountains" exactly describes the general appearance of the Fiji highlands, for they seem ever about to break in colossal waves upon the valleys and rivers below. And the colouring, the marvellous blues-blue as hyacinths under a summer sky, blue as sea-water lying six fathoms deep over a white coral reef, blue as a carven cup of sapphire filled with the violet light of sunset-what pen, what picture, can hope to reproduce them?

For many miles there was no sign of human life, and then, looking down from a windy crest of upland we saw a tiny village, Tambale, nestling far below in a deep wooded cleft of the hills. We passed this by, but after came upon an occasional small patch of yam or taro or banana; and soon the dark red variegated crotons and dracænas, planted along the track, showed us that we were nearing Nambukuya, the principal "town" of the district, where the Mbuli, or local chief, had his dwelling.

I wish I could describe Nambukuya, as I saw it on that golden afternoon, sleeping among the slanting shadows of its rich orange-groves, in the round green cup of a highland valley. On three sides of the little town the hills rose up like fortress walls of purple 
porphyry, but on the fourth, the lip of the cup was broken, and through the break one saw, dim and delicate and shadowy pencilled, the far-off pale blue plains of half a province lying below. . . . Surely I had seen Nambukuya before, but not on this mortal earth. It was in the strange country guarded by the "ivory gate of dreams" that I had wandered down those shaded, scented pathways and entered this little city of perfect rest and silence, soundless save for the cool murmuring of the stream that leaped right through the town in twenty little crystal falls, shut in from all the world, save for that one far-away glimmer of distant lands below. Every one who has ever been young, and dreamed over a book of poetry on some endless summer afternoon, knows of just such a spot. Mrs. Browning's "Lost Garden," Tennyson's "Island Valley of Avilion"-

"Where falls not hail nor rain nor any snow,

Nor ever wind blows loudly, but it lies

Deep-meadowed, happy, fair with orchard lawns

And bowery hollows

-the sweet, sleepy "Garden of Indolence," the solitary mountain valleys of "Endymion"-all these I had wandered through in the days when birthdays were far apart, and the dream-world endlessly wide; but I never thought to find myself, years after, in the prosaic noonday of life, riding a mortal horse through the actual Fijian highlands, right into the visionary city of my childish fancies.

All the pretty toy houses dotted about the neat little lawns were quiet when I jumped my horse over the bars, and entered the bamboo fence; for the people had gone away to dig in the yam-fields, and cut bananas. Just on my left rose, tier after tier, a strange erection of 
terraces, decorated with handsome, large-leaved waterplants standing in an inch or so of clear water. From terrace to terrace, a tiny stream slipped downward, losing itself at last in the river below. Nasoni and Joni told me that this really beautiful piece of landscape gardening was a ndalo bed, where the ndalo, one of Fiji's most important roots, was grown in the slowly running water that suited it best. Seeing that I was about to photograph it, they hastily got into the middle, and struck becoming attitudes. (I may here remark that Nasoni, who was the biggest and very much the ugliest of my men, was evidently the beau of the party, from the Fijian point of view, for when we left the village a day or two later, Gideon and Joni were allowed to go without remark, while a plump young woman, in lilac sulu and an arsenicgreen pini, or tunic, followed Nasoni to the farthest outskirts of the fence, sobbing unrestrainedly, and hanging on his apparently unconscious arm, without a shadow of mauvaise honte. I am bound to say that Nasoni acted exactly as if she were not there, and walked away, when she finally loosened her clasp, without a single look or word. Like beauty-men of other nations, he evidently set a fair value on himself.)

Our entry into the village roused out one or two lazy sleepers, who hurried forward in great excitement, for word had gone on of our coming, and we were expected. The native mission-teacher's wife was sent for, and informed us that the Mbuli, or district chief, was away, so I must come to her house. She proudly showed me in; and, indeed, the house was an excuse for pride. Big as a ballroom, and cool as a cave, in all that burning heat, it had an immense floor-space of the cleanest possible mats gaily edged with tufts of scarlet, orange, green, pink, blue, violet, black and white wools (of European make, 
these last). The great dim roof rose far overhead, unlighted; but the three doors that pierced the windowless walls gave each a different view of exquisite beauty, spread out below the lofty platform of green lawn on which the house was built. The walls were three feet thick, covered inside with elegant reed and sinnet-work, and outside with a deep thatch of grass and leaves that made the house look like an immense bird's nest. Now, and many times after, I was struck with the common sense shown in the design of these Fijian houses, and the excellent way in which they shut out the heat. I have never once felt hot in a Fijian house, no matter what the temperature outside might be, although European houses are often oppressively warm in the hot season.

Great was the excitement when the villagers came back, and found that the long-expected traveller was really there. A bush town in Australia visited by an unexpected circus may furnish a feeble parallel; or a remote English village, upon which a black princess, with her suite, should suddenly descend. The material furnished for chatter and discussion was, of course, invaluable. The two great ends of a Fijian's existence are eating and talking; he is always ready for either in unlimited quantities. Five pounds weight of solid yam is the minimum allowance for a single man's meal, among all employers of Fijian labour; and the abnormal capacity for eating which this suggests is fully balanced by the appetite for talk possessed by these mighty trenchermen. Wherever I spent a night, the greater part of the village sat up to talk till morning. In the nearest houses I could hear the faint buzz going on for hour after hour, as I slept and woke, and slept again, and I knew that in every town the same eager catechising of my men was going on, and the same endless discussion of my hair, teeth, eyes, nose, 
blouses, ties, belts, pins, skirts, shoes, shoelaces, problematical "underneaths," manners, temper, religion, age, history, financial position, relations, intentions, possessions and characteristics of every kind, down to the buckles on my side-saddle, and the things I had been heard to say when I stepped on a nest of wood-centipedes. But the folk in Nambukuya were considerate and polite, in spite of their burning curiosity. They did not shove or push, and when I lay down on the mats to rest, they softly closed the doors and slipped away, one by one, leaving me with nothing but the murmur of the high hillwinds about the house-top for company, and gentle twilight to encourage sleep.

Later on, came a feast-baked yam, and the great blue roots of the ndalo, served with the inevitable murdered fowl that is always given to a guest in Fiji. They don't truss fowls in the Fiji Islands, but serve them up with wildly divergent legs and wings, ghastly screwed neck still decorated by the protesting head, beak wide open and blank boiled eyes astare. After I had fed, the Turanga ni Koro (head-man of the town), came in with a formal gift of uncooked yams and a great yanggonaroot, which he laid at my feet with an elaborate speech. Yanggona (the "kava" of the Eastern Pacific) is the universal drink of Fiji. It is the hard, woody root of a handsome bush (the Piper methysticum), which grows freely in the mountains. The Fijians prepare the root by grating or pounding, pour water over the pounded mass, and strain it through a wisp of bark fibre. The resulting drink looks like muddy water, and tastes much the same, with a flavour of pepper and salt added. One soon gets to like it, however; and, drunk in moderation, it is extremely refreshing and thirst-quenching. The Fijians do not drink moderately, I regret to say; they 
often sit up all night over their yanggona, drinking until they are stupefied and sleepy, and quite unable to walkfor yanggona, taken in excess, paralyses the legs for an hour or two, even though the head may be quite clear. The British Government has forbidden the ancient method of preparing the root, in which it was chewed and spat out into the bowl, instead of being pounded. For all that, yanggona is very frequently chewed at the present day, when no white people are about.

I understood native customs sufficiently to give back the root to the donor, with many thanks, and request that it should be prepared for the people. We had, therefore, a single brewing from a portion of the root, little ceremony being made over the drinking, although the people clapped their hands loudly at me when the first cup was brought over to me. This is a form of greeting used for chiefs. The Turanga ni Koro, a rather unimportant personage, of no lofty descent, was the only dignitary present, so the affair was necessarily informal.

In almost all the Pacific islands, kava (yanggona) is the favourite drink of the natives. Its connection with early religious ceremonies is obvious, since it is generally prepared with considerable solemnity, and according to a prescribed ritual. Women and youths are not usually allowed to drink it.

Having finished the first bowl (which was prepared in a tin basin, as the mission-teacher's house dare not own a real yanggona bowl), most of the natives withdrew to another house with the root and the bark strainer; and I am of opinion that they kept it up that night until every bit of the great root, which weighed at least a couple of stone, was finished. At all events, my men were sleepy next morning, and informed me, with a satisfied air, that Nambukuya was "plenty good place." 
I stayed in the little village over Sunday, and a very interesting Sunday it was. At daybreak, the "lali," or canoe-shaped wooden drum, was beaten, and the natives held prayers in their own houses, first praying, and then singing Fijian hymns-loud, determined, sonorous chants, that sounded much more like war-songs than pious petitions. Three times during the day they assembled in the church (a large native house) for more praying and singing, and again at night they held prayers in their own houses. No work was done, except cooking yams and killing a pig for a feast in honour of my arrival.

The women dressed themselves gaily in green, pink and lilac tunics and sulus, the men all turned out in spotless white sulus and shirts, with black ties. It was evident that the religious exercises of the day were thoroughly to their tastes, and not at all too long. Fijians cannot be bored, and one of their favourite occupations, at all times, is sitting down on the mats in rows to chant in chorus, for many hours at a stretch, about anything and everything that may come into their heads. As for an unlucky white person, entrapped into a Fijian church, he must simply endure until it is over, as best he may. He will not want to go twice.

In the afternoon, everybody lay about on the mats, both sexes rolling and smoking endless cigarettes made of Fijian tobacco wrapped up in a slip of banana-leaf, and chatting rather lazily and sleepily. There was a smell of roasting food in the air; the shadows were lengthening, the cool of evening coming on. What thing that lay beyond that encircling wall of wide blue hills could the heart of man desire? Was not this the Valley of Peace, where no one wanted for anything, no one quarrelled or nagged, no cold or hunger ever came, nor fear for to-morrow, nor regret for yesterday? How 
easily might one forget all the world outside, and dream away the last years of a stormy life, cast up in this quiet bay of nothingness and peace, out of the wild waters of the white man's fierce existence?

But I was strong and young, and the white man's world still called for me. And next morning, when the sun was just lifting above the hills, and the great, green banana leaves were crystalled all over with dew, and the plumes of the waving guinea-grass were frosted glass and silver, I mounted and rode away for ever. . . . Yet, perhaps, in the gray years to come, I may find the gate among the orange-trees once more; may come back when the heart is old, and the world has wearied, to rest here in the arms of the purple hills, until the end.

One must stop somewhere in the matter of descriptions; I cannot make a pen-picture of the day's ride that followed. Enough to say that it was very lovely, and that my mind was almost wearied with beauty before that thirty-mile march was ended. There were other things to think of besides the scenery, however. The track was mostly red clay, and slippery as greased glass. My good Australian horse, Tanéwa, knew every inch of the road, and civilly declined to carry me over any spot he knew he could negotiate better without my weight. Once, at the top of a long down-slope that looked safe enough, I urged him on, after he had stopped. He grunted, and went forward under protest, picking his way carefully, for the path was but a foot or two wide, and there was a big unprotected drop into a mountain gorge on the off side. Suddenly, he struck a slide of red clay, treacherously hidden by leaves. Away went his hind legs, and, with a louder grunt than ever, he sat down on the slope, like a horse in a circus, his forelegs squarely planted in front, his hind hoofs tucked under the girths. 
Most horses would have snorted and struggled, and probably rolled over the precipice, but Tanéwa, as cool as a green cocoanut (there are no cucumbers indigenous to Fiji), merely turned round his head to look at me as I sat on his uncomfortably shaped back, saying as plainly as a horse could say it, "Who was right? I suppose you will get off now?" I did get off, feeling very apologetic, and the good Australian rose deliberately to his four feet, and pursued his way downward, quite unmoved.

By this time, word of our coming had gone round the whole countryside, and at every village we came to the same ceremony took place. I would jump Tanéwa over the pig-bars, and cross the green, desirous only of getting away (for the path invariably led right through the villages). The Turanga ni Koro, in a clean white shirt and sulu, would rush out at the sound of hoofs, and waylay my men. Then Gideon, all one grin, would approach me, and begin:

"Missi Ngrims'aw!"

"Yes?"

"Turanga ni Koro, he say toa (fowl) an' yam in the pire, pish he cook. He like you stop, ki-ki (eat)."

Then the Turanga ni Koro would proudly lead the way to his house, instal me on a new mat, specially unrolled, and enjoy a good gossip with my men. Enter the murdered fowl, and the inevitable yam; perhaps a steaming leaf-full of plump river-prawns as well. I would cut a small piece off the fowl, and eat it for manners' sake, while my men, after I had done, would joyfully rend the remains limb from limb, and devour every bit, not to speak of a trifle of five or six pounds of yam apiece. Then I would make a small present, for courtesy's sake, and call a fresh start. After four feasts (counting the morning meal at Nambukuya), I began to reflect that 
neither Stanley, Burton, nor Speke would have allowed his men to make themselves sick with over-eating (for even a Fijian can eat himself sick on animal food, which he does not often get), and I resolved to put a stop to it. I wished very much, however, that Stanley had been around to tell me how to do it. I had an idea that he generally hanged his followers when they disobeyed him, but I had never hanged any one, or even seen it done, which was certainly a difficulty in the way. There is nothing like travel in rough countries for teaching you your own deficiencies, as I had already learned. I could write Latin verses, but I couldn't make bread-I could embroider on silk and canvas, but I didn't know how to grease my boots properly-and here was another simple thing, just the hanging of a Fijian, that I could not do, either. I felt it was like something in "Sandford and Merton"- -something with a moral to it-but could not quite remember what.

Under the circumstances, the best thing to do seemed simply to decline to stop at any more villages, and I did, though the disappointed faces of the villagers I left behind me almost shook my resolution. The plan seemed to be working all right, and I was getting rapidly on toward the Singatoka Valley, when, a mile or so after we had crossed a river, where a party of natives were cooking yams on the bank, I missed Joni and Nasoni.

"Where are those men?" I demanded sternly.

Gideon, with an ingratiating smile, replied:

"I think they stopping along water-get some-sings to eat!"

This was the last straw. I gave Gideon my opinion of himself, in what the popular novelists call "fine, nervous English" (it must have been, because it obviously made him nervous as to what might be coming next), and 
told him that it was entirely his fault for letting the men stay; also that I would not give them any tobacco money for the next Indian store, or any more stray handfuls of sugar to eat on the road; and that I was going to ride on now, and let them follow as they liked. The country was growing more level, so I put Tanéwa to a canter, and kept him at it for a good while. As a result, the three men were very tired and hot when they caught me up later in the day, and looked rather penitent. I was glad, on the whole, that I had not hanged them, especially when I heard Nasoni remark, with a chuckle, to Joni that they would get plenty of roast pig at Natuatuathoko, where we were to stop the night-for it seemed to me that Nature herself would probably attend to the matter of their extermination before very long.

All day, as I rode along, the same thought kept coming up in my mind. Why should all these miles and miles of fine highland country lie empty, untouched, uninhabited? The Fijians did not need them, and were ready enough to let, or even to sell, under the new laws which provide for the improvident native by giving the capital into the permanent charge of the British Government, and only paying out the yearly interest. The climate was splendidly healthy; the occasional forests only covered a small part of the country, and were valuable in themselves for their timber; there was abundance of water, and the bridle-tracks were everywhere good enough for driving stock down to the coast. It had been proved that horses and cattle did excellently all over the country, and sheep in the hills. The sales of Australian and New Zealand tinned beef and mutton in the country were enormous, in spite of a heavy duty. Anyone who started a cannery in the islands, so as to avoid the duty and undersell the imported article, would 
make a fortune. Further, there was a good export trade in beef only half developed. And apart from this altogether, coffee, sisal hemp, jute, and many other valuable commercial products, were known to do excellently in the hill country. Where were the settlers? and why did they not come?

I have never, as yet, been able to find a satisfactory reply to the latter question, except in the aggressive attitude adopted by the oldest inhabitant to all new blood and new-fangled ways, and, possibly, in the small attention paid to such matters by the Fijian Government, until very recently. Even at the time of writing, it is not at all easy to obtain reliable information about the exact amount of waste lands available for cultivation. I can only tell the would-be settler that there is certainly plenty of land to be had, and that details can best be obtained by going inland to look matters up in person. I hear that the Government is having a survey made, but it will probably be a long time in the making, as a government, like an alligator, requires considerable space and time to turn around in. In the meantime, a few of the rough facts which I obtained about this part of Fiji, in the early part of 1905 , from local residents of long standing may be of interest.

On the Ba River, about I 00,000 acres of native land, 600 feet above sea-level, is available. It is extremely suitable for stock-raising. Rents probably not more than a shilling an acre.

On the Tavua River, about I, ০০o acres of similar land.

Between $\mathrm{Ba}$ and Nandrunga, a stretch of land six or seven miles across, some hundreds of feet above sea-level, suitable for coffee, or for stock-raising. Quite uninhabited. Plenty of water.

Between Nandrunga, Nambukuya and Natuatua- 
thoko (over forty miles) the entire country, with one exception of a few small yam-patches about the villages, is unoccupied, and the greater part available as above mentioned.

Yanggona, which sells for $1 s .6 d$. a pound in Fiji, and is used in the pharmacopœa of almost every country in the world, grows wild among these hills, in the woods. Citrons and lemons of fine quality also grow wild.

I would like to add here, that the present state of Fiji-just beginning to open up for settlement, with lands as yet unsurveyed in great part, and much of the interior only roughly known-is just the period, in any country's history, when settlers light upon the best chances, and get on most rapidly. After everything has become smooth and easy, and the value of all the lands is accurately known, and the products that suit the country and the markets best have all been tried and exploited, the cream is off the milk-skimmed up by those who were enterprising enough to take the chances, and try to be the first in the field. Fiji is no place, as yet, for the young man who never had an enemy in his life, but, somehow, isn't wanted at home; who has a moderate capital, and a moderate amount of character, and can get along very nicely if some one tells him just where to go and what to do, and how to do it; who is excellent on a tram-line of habit and custom, but as incapable of making a fresh path for himself as the tram-car itself might be, off the line. Men of another stamp, who will help the colony to find itself, are what Fiji wants, and there can be no manner of doubt that it will have them, as soon as the public can be got to realise that the country is one of our most important Crown Colonies, that Fijians are neither dangerous nor cannibal, and that the climate is one of the finest and healthiest in the world. 
. . But, after all, who could be practical and statistical within sight of Natuatuathoko?

We were nearing it now, this mountain fortress town in the very heart of the highlands. The Singatoka River lay on our right, the hills were behind and before, but we were travelling now over a stretch of rich, level, meadow country, where the fine, soft grass rose waist-deep on either side, and the road itself was a wide, turfy avenue, bordered here and there by splendid orange and lemontrees in full fruit. By-and-by, the track took a sharp turn upward. We were leaving the river valley, to ascend the strange little hill on which the town stands, as upon a tower. Now the grassy road became steep and stony, and the orange-trees almost closed in overhead. And on each side, as I rode along, bushy crotons and dracænas, scarlet and black and yellow, made a quaintly ornamental hedge, while tall guavas shot above them, and dangled great golden eggs, bursting with the richness of the luscious pink pulp within, right over my lap. I accepted the generous invitation freely; and in the rear I heard a crunching and sucking that told me the ever-hungry Joni and Nasoni were "at it again." Well they might be, for nowhere in Fiji are oranges and guavas like these to be found.

Higher up, and still higher! The path was neatly edged with stones, and partly paved, but the horse scrambled and clattered a good deal, for the way was steep. Groves of exquisite bamboo, orange and lemon shut in the track so that one could see little ahead. But suddenly the way opened out, and before me stood an immense Fijian house, seventy or eighty feet high, the great roof crowded with men who were rethatching it, aided by a scaffolding of bamboo. They raised a yell that made even the sedate Tanéwa start and shy, and 
shook their knives in the blue air, high up under the sky. Then they began to scramble down the house like cats or flies, and made a rush for me and my men. Even so, thirty years ago, had the fathers of these men-some of the elders themselves, indeed-rushed to greet visitors to Natuatuathoko, with brandished weapons and terrifying cries. But in the old days, there was war-paint on their faces, the weapons meant strict business, and the cooking-ovens, in the village above, were hot to receive the luckless visitor, not to entertain him. To-day, the men of this mountain town, once the home of every devilish cruelty, were running and shouting, and swinging their cutting-knives about, simply to express their uncontrollable delight at my arrival. A white woman up here! a white woman alone! what a tremendous event, and what a source of mad excitement! Why, there was not a white face for fifty miles on either side of Natuatuathoko, and the magistrate himself only came round to hold his court, in the big house they had been thatching, once in every six months!

I feel inclined to say that "a hundred willing hands were extended to lead my horse into the town, and help me to dismount," because it is the proper, signed-andsealed sort of phrase to use on an occasion of this kind, and the Natuatuathokians certainly ought to have done it. But, as a matter of fact, they did not, being far too much occupied in staring at me to think of anything of the kind. When I dismounted outside the bamboo stockade, and scrambled over the stile into the town, they rushed to look at my side-saddle, crying out, "Sombo, sombo!" (Wonderful!) Then they stared at my habit-skirt, which I was holding up as I walked, and expressed their admiration of its length by loud "tcktcks." They told my men that I must be rich, to have 
such a long sulu as that, and that I was certainly an "Andi" (high chieftainess), because of my height, which was equal to their own. (In Fiji, the chief families are all tall, and a tall woman, in particular, is almost sure to. be of the blood royal of Bau, Thakombau's birthplace.) Following at a respectful distance, they accompanied me into the town; my men, as usual, enjoying the glory of the arrival exceedingly, and competing with each other in the size and splendour of the lies they told about me. I was the sister of the Governor of Fiji (a fact that would have greatly surprised His Excellency if he had heard it); I was also a most intimate friend of King Edward VII., who had specially despatched me from England to tell him what Fiji was like. Moreover, my father had so many cattle that England was too small to contain them, and I was therefore asking questions, wherever I went, about the amount of vacant grazing-land to be had in Fiji for these superfluous "bulimacow." (Bulimacow is the Fijian word for beef, and for cattle, singular or plural. A milch cow is a bulimacow; also a bull. The origin is obvious: confusion caused by asking the name of the strange creatures when they were first brought to Fiji.)

I did not pay much attention to these pleasing fictions, however, for I was now within the town, and Nambukuya at once fell from its pride of place in my heart. It was not the most beautiful village in the world; that honour was transferred to Natuatuathoko, henceforth and for ever. . .

- . Little enchanted town, how you linger in my memory, though I spent only a night and a morning in your wonderful citadel! How often I think of you, as I first saw you from the grassy orange avenue below, perched high upon your green pinnacle like a fairy 


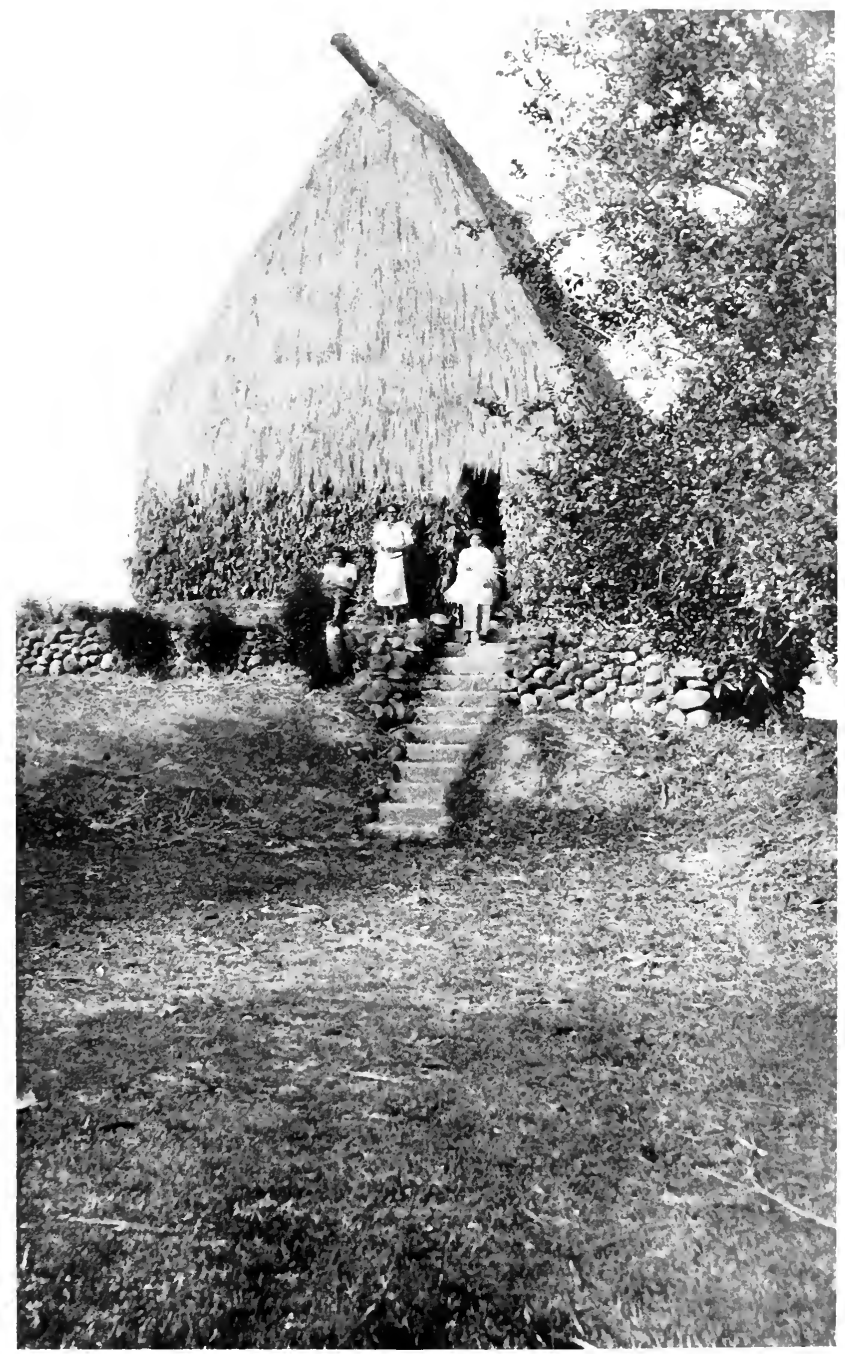

HOCSE OF THE TLRANGA LILEWA 


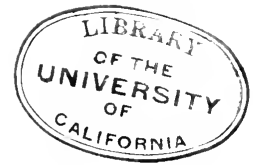


town in an old-world story-book! The tale seemed to tell itself, as Tanéwa plodded steadily along in the yellow sunset.

“. . . And they travelled all day long, through the black woods where the goblins live, and over the mountains of No-man's-land. And at evening they came to a beautiful river, that was deep blue, and the birds sang in the trees beside it. Then they saw the road that led to the magic city, stretching right before them, all green and soft, and the most lovely fruits grew beside it, and dropped on the path, with no one to pick them up. And the magic city stood up in the clouds, and there was a wall all round it, but if one stood at the gate, and pronounced the words, 'Open, Sesame!' it opened immediately.

And upon what did the magic gate open?

Upon a small grassy lawn, surrounded by a ring of about a dozen quaint little native houses; upon a tangle of heavy-fruited mandarin orange-trees, lemon-trees, guavas, scarlet-blossomed hibiscus, and graceful giant bamboo, framing blue distances in the most beautiful of natural arches and windows; upon an airy circle of clouds and shadow-dappled hills, and far-away faint-green meadows, ringing round the little fortress town with what seemed a vision of "all the kingdoms of the earth, and the glory of them." Very far below, the blue Singatoka wound like a ribbon about the base of the hill, murmuring sleepily and ceaselessly all day and all night long, in the stillness of the mountain air. They are strangely silent, these hill towns, even in the early morning and evening hours, when all the people are at home. The lightly treading bare feet of the mountaineers make not so much noise upon the grass as a ripe orange falling from the tree; children do not shout at play; there is 
no calling out to teams, or dragging of heavy boats, or sound of wheel or hoof, for countless miles beyond the mountain wall-only the high hill winds in the whispering bamboos, and the long murmur of the river.

The house to which I was conducted remains in my memory as the most delightful I saw in Fiji. It belonged to a chief of some importance-the Turanga Liléwa. It stood upon a mound at least twenty feet high, approached by a long flight of steep stone steps, and from every one of its three doors one looked down, in the early morning, upon a rolling sea of pearl-coloured mountain mists, islanded by sharp violet crags and summits. With the springing up of the clear white sun, these opalescent mists broke and shredded away to garlands of lightest thistledown, hanging about the dark-blue shoulders of the hills; the river turned to golden glass, the yellow balls of the oranges began to burn like fire, and sudden day broke upon the silent town. Yet, perhaps, it was more lovely still in the moonlight, the warm, wonderful tropic moonlight that painted all the widespread distances in delicate silver and misty blue, and frosted the dew-wet domes of the strange peaky houses with elfin touches of sparkling crystal. . . . If Nambukuya was a place for the old and weary, here was a place for the young and happy: for Romeo and Juliet, for Sidney and Geraldine, for wonderful story princesses, eloped from gloomy palaces to the wilderness, and a cottage, and love. . . . And there, in the middle of the village, was the cottage all ready-a cottage ornée, fit for a princess who had not yet learned to do without her high-heeled satin shoes and her nécessaire-quaint beyond description, with a European veranda, and an enormous high-pitched Fijian roof, and odd little rooms partitioned off from one another by cool walls of fitted reeds. It had been built for a former 


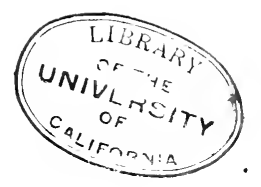




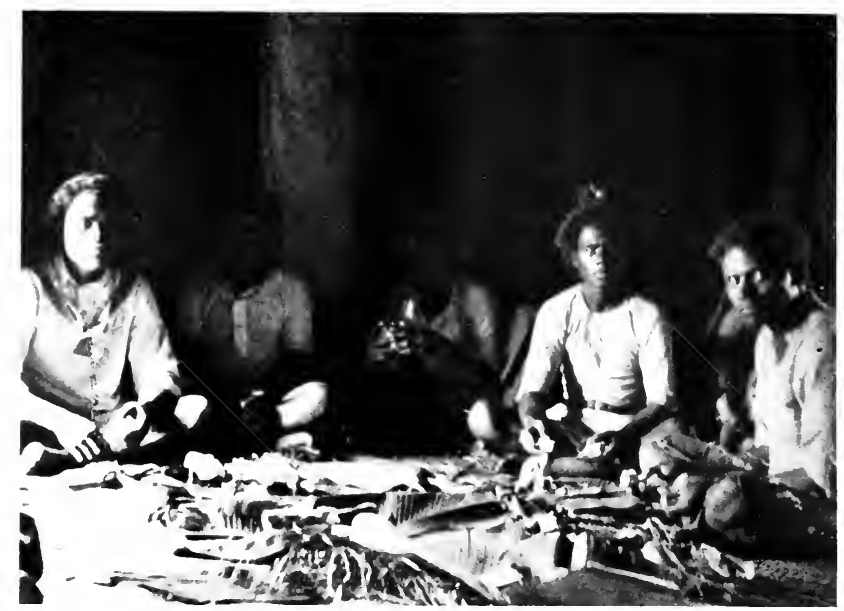

A IEAST BY THE WM

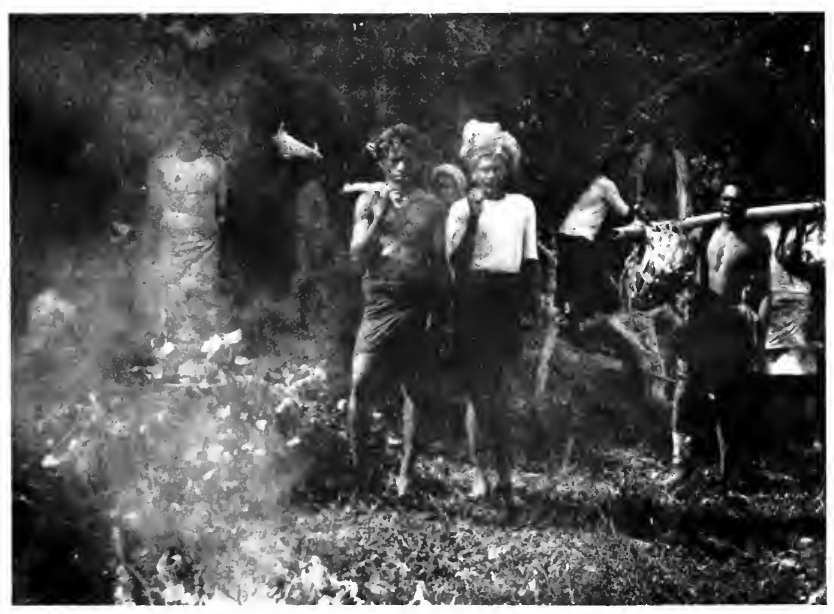

IBRINGING L'P THE Y.IIS 
white resident-the officer in command of the native garrison that used to occupy the town-and was still in good repair, being occasionally used by the district magistrate on his travels. An odd, delightful spot; a hothouse for strange fancies, and fantastic fairy imaginings born of long days' solitary travel and long hours' moonlight thought.

But, really, it is time to get away, for there is a big distance to cover to-day, and the men have finished their feast of yams and pig and fat river-crayfish, and the bridle is being forced upon Tanéwa's mildly protesting head once more. So it is "boot and saddle" again, and ride away, the richer by an exquisite picture of beauty, and one or two oddly comic experiences. Among these must be included the special honour paid me by the wife of the Turanga Lilewa, who proudly brought out a chair and table (evidently home-made), at which I was requested to take my dinner. Chairs and tables, in the mountains, are unheard-of luxuries, and the Turanga Liléwa is very proud of possessing these objects of art; so much so, that I had not the heart to tell him that he had got the relative heights hopelessly mixed-the chair being a giant of its species, while the table was not eighteen inches high. I ate my dinner on it, rather than hurt his feelings, but I felt inexpressibly ludicrous, and remarkably like a chicken drinking. 



\title{
CHAPTER IV
}

\section{HOSPITALITY}

\begin{abstract}
"Plenty Shark"-Introduction to a Mbili-mbili-Down the Singatoka River-A Meké-meké at MavnaThalassa
\end{abstract}

FTER Natuatuathoko, the journey became inextri-
cably involved with the Singatoka River. All day I was concerned with that stream, fording it more than once, climbing up and down the hills that bordered its banks, and at last cantering easily for many a mile through the beautiful river flats of the middle reaches, the richest land in Fiji. There is almost nothing that this land will not grow, and grow excellently. Sugar does well on it; vanilla would flourish in all the little valleys; bananas grow splendidly here and there, where an enterprising Chinaman or two has taken up land; cocoanuts bear heavily; cattle, if one may judge by the specimens feeding here and there along the banks, grow as beefy and big, as silken of coat and bright of eye, as any prize beast bred in English meadows. It may be said here, once for all, of the Singatoka River country, that the land is unsurpassable, that many thousands of acres are to be had, and that the rents asked by the natives are very low-only a very few shillings per acre in many cases. It is popularly said in Suva, by people who have never left the towns, that the bar at the mouth of the river is an insuperable obstacle to the development of the country. This however is not the case. The bar does 
prevent steamers from coming up, but the Chinese settlers seem to experience no difficulty in getting their fruit disposed of, by means of lighters, which convey it down to the sea, to meet the calling steamers. Nor is the bar necessarily a permanent obstacle, since something less than two thousand pounds will remove it, as soon as the Fiji Government sees its way to spend the money. The climate of the Singatoka is excellent; clear, bright and healthy, and not excessively wet. There are no fevers or diseases of any kind, not even malaria.

Villages were very few to-day, so the men did not secure more than one or two feasts before we reached the stopping-place for the night. We halted after a day's travel of only about fifteen miles, since heavy rain that fell in the middle of the day had delayed us an hour or two. The sun had just slipped behind the hill when we reached the lower Singatoka-a stream very different from the shallow, brawling waters we had left earlier in the day. This was wide and strong, dark agate green in colour, and exceedingly deep. The night was coming very rapidly; there was not a soul in sight, and no boat visible. My men tied up Tanéwa in the long grass (since he was to be sent back next morning from this side of the river), and then sat down and began rolling cigarettes. Whether we were going to get across the river before dark - whether we were going to arrive anywhere to-night-what we were going to do anyhow-did not trouble them in the least. That was "the white man's burden" (or, in this case, the white woman's)their burdens were my box and provision-bag, nothing more.

"Is there no boat?" I asked Gideon.

"No, sir," replied Gideon, with the utmost cheerfulness. (The Fijian generally addresses a lady as "sir.") 
"No ford anywhere?-no place we cross?"

"No, sir,"

"Then we'll have to swim, and pretty quick about it. It's getting dark."

"All right, sir," lighting a cigarette and rising to his feet.

I had dressed myself in expectation of some such contingency, and had only to remove my riding-skirt and shoes. This I was proceeding to do, when Gideon remarked conversationally, with a brilliant smile:

"Plenty s'ark here."

I stopped at the laces of the second shoe, and asked anxiously:

"What shark? All same Réwar shark stop here?" "Yes, sir. All same. Plentee."

This gave me an unpleasant sensation down the spine, for I had heard many things of the Rewa River sharkshow fierce they were, how they would swim up the river for fully thirty miles, how they bit arms and legs off careless bathers, as the records of the local hospital testified. And now I was informed that the Singatoka was infested in the same way.

Stanley wouldn't have minded those sharks, I felt certain. The men obviously did not. But I did, and I hesitated.

"Sa lakomai mbili-mbili" ("There is a "mbili-mbili" coming"), remarked Nasoni at this stage, pointing out across the water.

I looked about, half expecting to see some strange river-beast or fish rising from the glassy tide; but a much more welcome sight met my eyes - a small bamboo raft, coming across from the other side, paddled by a native. In a few minutes it was alongside-a mere bundle of sticks with a depression in the middle, and a sort of 
rough bow formed by tying the small ends of the bamboos tightly together. Such as it was, however, I welcomed it gladly, for Lemba-Lemba, an important town, was on the other side, and I had got to cross to-night, or drown.

Saddle and luggage were piled on the mbili-mbili, and I perched myself as safely as possible on one side.

In the gathering dusk I could just see white sulus flitting about upon the further shore; it was evident that we were expected. When the raft grounded, a big, jeteyed, jet-bearded native, with a fine, dignified presence, a neck and chest like a bull, and a voice to match, came forward and welcomed me as one having authority. I did not need to be told that this was the Buli, or high chief of the district, for the deference paid to him by my men at once informed me of the fact.

Good Buli of Lemba-Lemba! what a pleasant memory you left in the mind of the wandering marama, long after she had sailed away from your hospitable town. Here, at last, was someone with a head-kindly, hospitable and jolly, quick to give orders, ready to stir about-a relief indeed from the amiable dependence of the men. The ascent from the river to the village was almost unscalable that night, being nearly perpendicular, and so slippery with recently soaked red clay that it resembled a huge toboggan slide much more than a path. Even the bare feet and strong prehensile toes of the Fijians slipped on it, while I simply could not keep my footing at all. But the Buli roared like his namesake animal, and out of nowhere appeared two men armed with spades. These scrambled in front of me, cutting steps as they climbed, while another man, and the Buli himself, held my elbows, and hoisted vigorously. In this fashion, all in the dark, I came up to Lemba-Lemba, and was ushered into the 


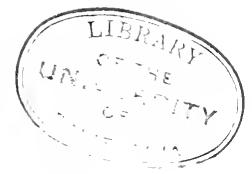




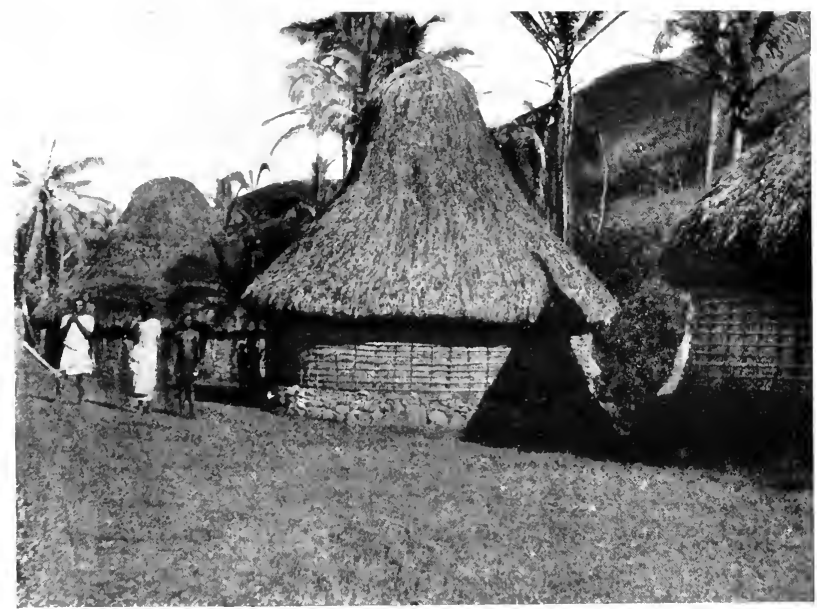

MORNING, LEMBA-LEMBA

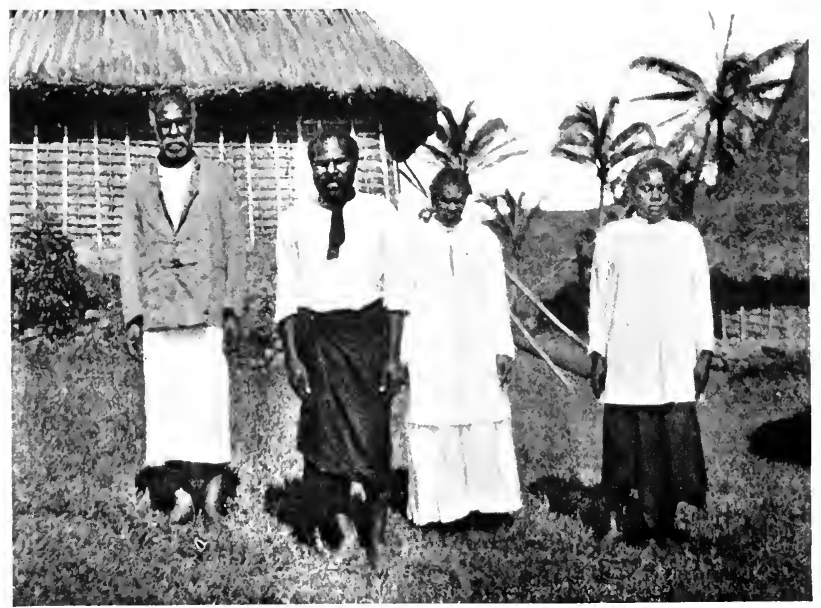

THE BULI OF LEMBA-LEMBA. WITH FATHER ANI) FAMILY 
Buli's own house, where supper was already waiting, hot from the cooking-pits-ndalo, yams, crayfish, cocoanuts, fowls, and a brace of plump sucking-pigs, cut up into joints. All this was laid out on a real table, with two real chairs, on one of which the good Buli took his seat, a perfect firework of eyes and teeth and glowing goodnature, while I took the other. He would not eat till I had finished, however, and all the time, according to custom, my hungry men squatted quietly on the floor, waiting for their turn. Many a time, both then and afterward, I longed to give the patient, tired creatures their food, as soon as I was helped myself, instead of keeping them waiting until my tea was made and my meal finished; but I knew that this was undesirable, and would probably make them unmanageable later on. One hard lesson that the white man or woman must learn with regard to Fijian servants is not to be too kind. They may be considered in private, but one must never openly show them that their comforts are a matter of thought; and the respect that they freely offer must not be broken down by any lessening of dignity on the white person's part. Like all savage races, they count kindness as weakness, and although I have not, personally, found them incapable of gratitude, I have found that an act of indulgence, such as a gift of tea or tobacco, or a little skilled care for some small injury, must needs be balanced by a certain manufactured hardness of demeanour, if it is not to form a ground for future laziness and carelessness.

This question of gratitude is a vexed one. Most of the other writers say that the Fijians possess no such feeling; and certainly, what they may have is of a quality different from ours. I have heard of a kindly old lady (a white settler in Fiji), who tended a young Fijian through a bad attack of dysentery, and succeeded, with 
much trouble, in saving his life. After he was well, he came up to her house, planted himself on her veranda, and demanded food and lodging. When she refused, he was extremely indignant, and asked her, in an injured tone: "Did you not save my life?" "Certainly I did," said the lady. "Then, of course, it belongs to you, and you must provide for me!" declared the Fijian. His benefactress, rather taken aback, tried to decline the responsibility as politely as might be, but the Fijian stuck to his point, and, only for the intervention of a Government official, who was so tickled with the originality of the affair that he carried the man off to Suva for a servant, the kindly lady would probably have suffered a good deal of annoyance.

This is one side. There is, however, another. I have known one of my men, to whom I had given an odd sixpence for tobacco, collect all my shoes, and take them off to clean immediately; and, on the journey through the mountains, my interpreter more than once refused tea for himself and the others, on the grounds that I gave them "plenty ki-ki" (food), and that I should not have tea enough for myself if they shared it. To see them afterward, when we had reached an Indian store, boiling their tea furiously over the fire till it was black and thick as treacle, and then drinking it, sweetened to syrup, with an expression of the most heavenly ecstasy on each black face, was to understand that they had, previously, made a real sacrifice.

The Buli shared my tea, on this occasion, with much delight. Gideon prepared a specially powerful cup, well stewed, for him. To present it, he squatted down on the ground before the Buli, lowered his head, and held up the cup, humbly saying: "Na ti, Turanga" ("The tea, O chief!") The Fijian "kaisi," or commoner, pays 
immense respect to chiefs, and never dares to address them unless squatting humbly on the ground at their feet. Only an equal addresses a chief while standing.

After everyone had fed, and was satisfied, the Buli put my men through a searching catechism as to myself and my doings, enjoying the good gossip as heartily as any old maid in an English chimney corner, and roaring with laughter over some of their replies. It was then explained to him that I should want the whole house to myself that night, with his wife to keep me company. The idea of being turned out of his chiefly mansion in favour of that unimportant item, his wife, struck the Buli as the greatest joke of the season, and his fat sides fairly shook with laughter, as he bade me good-night, and waddled down the cocoanut log out into the dark. I fancy he ordered Gideon to sit up in the neighbouring house and entertain him with conversation all night long (Fiji fashion), for the low buzz of talk, punctuated by an occasional bellow of enjoyment, was distinctly audible until daybreak.

In the morning, the Buli offered me a pressing invitation to stay a day or two longer; but time was not unlimited, so I rather reluctantly left the pretty town and its hospitable chief, giving two or three shillings in exchange for my lodging, and, as usual, finding that my small "tip" was considered extremely liberal. Now came a difficulty. Tanéwa had been sent back, according to previous arrangement, and behold, the boat we had expected to meet us was not there. It had gone down the river because of the "Bosi Vakaturanga," I was told. As the Bosi, or Council of Chiefs, was being held in Suva, a hundred miles away, it was difficult to see the connection, but the fact remained. The mbili-mbili must carry us down to Koronisingana; there was nothing else to be had. 
So, on to this bundle of sticks my baggage, my saddle, myself and followers were packed, and we began our slow drifting down the river. A proper mbili-mbili is not too rough a craft; it has a sort of fence in the centre, enclosing a comfortable seat, and is made with some consideration for the matter of keeping its cargo dry. But our conveyance boasted only a sort of rise or hillock on each side of the central hollow; and, as I sat with my feet in the latter, I could feel the water squirting up my ankles every time the men made a feeble stroke with the awkward bamboo pole. It had to be used as an oar, for the river-which I could see right under my feet between the bamboos, green, sunlit and clear-was much too deep about here to allow the raft to be punted along.

There was every opportunity for observing the country as we drifted by; and a very lovely country it wasrich flats along the river shores, thick with the finest grass, wasting away untouched, year after year; picturesque cliffs sheltering the stream; long, hot, damp gullies here and there, just the places for vanilla-growing; and always the murmuring green river, winding endlessly ahead, and the far, soft hills of hyacinth blue. So we drifted on, into the country that I did not know; and under the open sky, in the warm, fresh, river wind, life seemed very good.

We had had a feast of fowl and pig in the morning, and a lunch of tinned meat and biscuit about midday. But that did not trouble the men at all when we got to Koronisingana in the early afternoon, and found that the local chief had slain the fatted hen once again. I will swear upon my honour and conscience that they had eaten enough for ten already that day, before they sat down to two fowls among the three, and cleared them away, with ten or twelve pounds of 


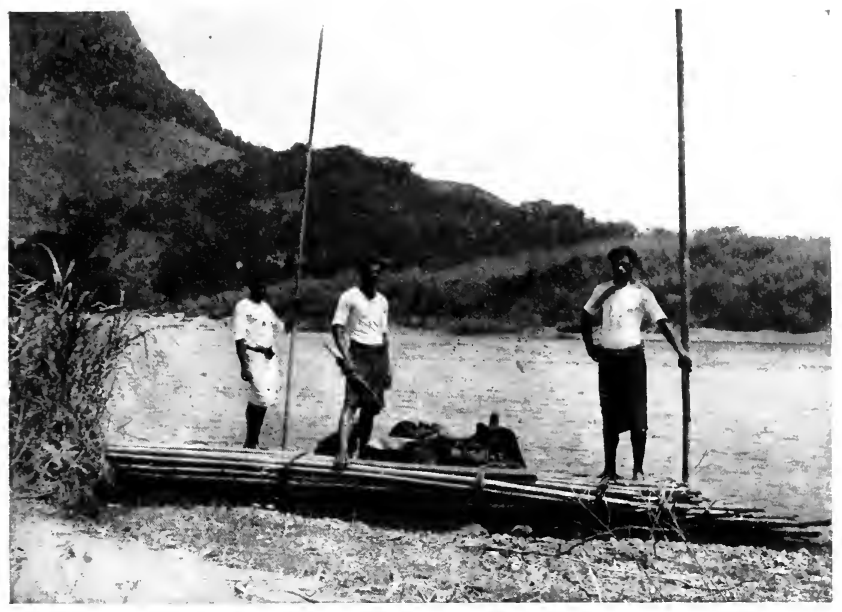

MY FOLLOWERS ON THE MRILI-MBILI

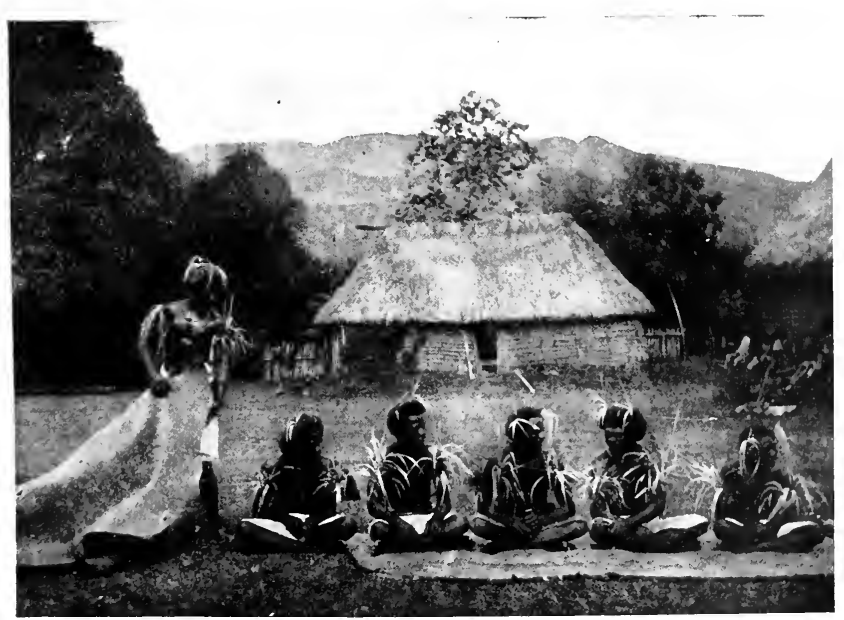

GETTING READY FOR THE MEKÉ-MEKÉ 


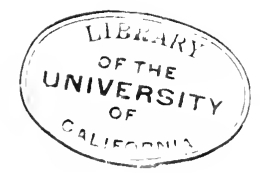


yam. When they had finished everything within sight, they got up, said it was a good town, and that the Singatoka people would all go to heaven; and then went off to bale out the boat I had hired, and transfer my goods from the mbili-mbili. I wandered about, looking at the pretty village, which was quite unlike the mountain towns-much more straggling; not in any way fortified, and less quaint in its architecture, since it wanted the high mounds on which the mountain houses stood. But the beauty of its trees and shrubs quite made up for any lack of architectural interest. Every house stood in a grove of many-coloured shrubs, and white and yellow flowers, with splendid tall cocoanuts and big, shady mangoes overtopping all. Paw-paws loaded with their delicious little tree-melons, stood by almost every door, and there were oranges there, too, as in every Fijian town.

The Buli's house had a European toilet-glass; and my men took full advantage of this, setting it on the floor, and squatting before it in turn, to oil, stick up, and decorate their hair. No London lady with a mass of artificially produced waves and curls is more anxious about her hair than a Fijian. In rainy weather, a smoked banana-leaf is often used as a waterproof cover for it, closely tied over the head. Those who do not dye the hair yellow with coral lime, or red with annatto, generally touch it up with soot to ensure its being of a dense blackness. It is, therefore, not so completely weather-proof as one might imagine, and is only kept smart by continual vigilance.

The boat leaked badly, and the men had to bale in turn all afternoon. This did not trouble them, however, since all native boats leak, and the baler is generally as active as the oar. We had neither oars nor paddles, 
the only means of progression being a bamboo pole. This was slow, so when we came to the shallows, Joni would get out, and run, knee-deep, behind the boat, pushing it gaily in front of him, for miles at a time-a method of progression entirely new to me, but apparently well known to the men.

Towns were scarce in this part of the river, and my followers only succeeded in securing a fourth feed of one fowl and a few pounds of yam, before we reached Mavua, the biggest town on the Singatoka, where the growing dusk obliged us to stop. How much they ate there, I should not care to say, being anxious to retain some character for truth-telling, in the midst of a scepticalworld.

The town could not be seen from the river, but as our boat turned in to the shore, and grounded near the bank, a Mavuan suddenly appeared from nowhere, dressed in an extremely small sulu, and armed with a knife three feet long. Seeing that we were going to land, he commenced a mad dance on the river flat, under the orange sunset, his high, stiff hair shaking about on his head like a bed of sword-grass in the wind, his knife circling round and round, while his huge mouth, every now and then, emitted a yell of the wildest excitement.

I longed for a better light, to snapshot this strange vision, and stranger welcome, but the sun was already below the horizon, so that I could not secure a picture that forcibly recalled-in appearance-the not-so-longago days of the death-drum, the strangling noose, and the "bokolo" (human body) served up smoking hot, with savoury herbs, for the sunset meal.

The amiable savage on the bank stopped dancing as soon as we reached the shore, and hastened to hand me out of the boat with a vigour that simply "yanked" me over the gunwale, two or three yards out on to the gravel 
flat. He then drove my rings into my flesh by an agonisingly hearty shake-hands, went and picked up the bundle of reeds he had been cutting, and ran ahead of us up to the town, whence an excited crowd issued at once to escort us in.

Another pretty village-another hospitable Buli; and something new this time in the way of houses, for the Buli of Mavua has one of the very finest houses in Fiji. It is about as large as an ordinary country church, or town hall, with a tremendously high-pitched roof, and a touch of European civilisation in the shape of two glass windows, which make it unusually light. The bedplace would accommodate three or four large families, and the yanggona bowl is the pride of the Singatoka. By its dark colour and thick, opalescent blue enamelling, I judged it to be an heirloom many generations old. It was the size of an ordinary spongebath, and was cut out of one solid block from a giant forest-tree. Such a bowl as this is greatly prized, and proportionately valuable, for collectors of island curiosities are ready to pay large sums in order to obtain a good specimen. Most of the chiefs, however, prefer to keep them.

At Mavua, I was entertained with an excellent mekémeké, or song and dance. There had been a small one at Natuatuathoko-a sing-song that lasted for several hours, beginning with some verses about myself, going on to celebrate the glories of the horse Tanewa, branching off after that into something about the Andi Keva, a coasting steamer, and subsequently chanting the saga of all creation, from Adam down to the latest Colonial Secretary, so far as I could judge. But that was rather an unimportant function, whereas the Mavua meké-meké was one "with all the frills on," got up, at some cost of trouble, by the young men of the town to honour my visit. 
It took place after the usual pig-and-poultry feast, in the morning. A number of the youngest and bestlooking men attired themselves in white sulus, rubbed themselves with scented cocoanut oil until their skins were like dark-brown satin, and tied bracelets of striped green-and-white ribbon-grass about their arms. They also placed aigrettes of ribbon-grass in their hair, and fastened bunches of brilliant coral-coloured flowers wherever they could be made to stay about arms and shoulders, or among the ribbon-grass in their yellow-dyed locks.

Thus attired, they looked a very smart and personable set of young men, much more pleasing in appearance than any other Fijians I had yet seen. The people of Mavua have a tradition that, early in the nineteenth century, a white man came to live in their town, and took to himself several Mavuan wives. The half-caste children of these, marrying among the pure Fijians, introduced a strain of white blood, the effects of which (or so they say), are felt to the present day. Certainly, the Mavuans are somewhat lighter-coloured as well as better-looking than the people of the other river towns. But I could notice no trace of white ancestry in the hair, which is as stiff and woolly as that of any other group of Fijian people.

A mat was spread on the ground, and the young men squatted on it in a row; one, placed at the rear, keeping time to the music by clicking two sticks. The performers began by slapping their hands in unison, and then launched out into an extraordinary and graceful sitting dance; heads, bodies, arms and hands swaying with one impulse, in perfect time. Sometimes they all swept low to the left, as if mown down by a scythe; sometimes they gathered invisible armiuls into their arms, or 
pointed at unseen sights; sometimes they raised an indescribable twitter and twinkle of all their bristling decorations, shivering and shaking as they sat. And all the time they sang, with strong, splendid, sonorous voices, a wild, sinister chant, that waxed louder and louder, fiercer and fiercer every minute. What brazen throats! what resonant lungs they had! The booming of the bass resounded like the "bourdon" stop of an organ, and the wild wanderings of the melody (if such it could be called) brought to mind the rushing of sea-winds in the huge fronds of the cocoa-palm, above the surf of a spouting island reef. For an hour or so they sat and sang and swayed, and then they stopped to clap in chorus once more, and ended. The words were indistinguishable throughout-not many of even the Fijians can tell the exact meaning of the verses used in one of the traditional ancient meké-mekés-and I could not obtain any explanation of the actions, but some of them seemed distinctly suggestive of fishing, and the river.

Of how we got away-of how we passed several towns and stopped (by earnest request) to feast at four, on pig, yam, crayfish, fat river-clams, and stewed fowls cooked with native peppers and shallots; of how the men plotted to stop at yet a fifth, and incited Gideon (who was a lordly person, and didn't have to row) to tell me that Nasoni was worn out with fatigue, and would be ill if I did not shortly call a rest; of how I sternly answered that Nasoni might rest in the boat, and Gideon (who laughed wildly when he saw how he was caught) should take his turn at the oar for once; of how the Buli stood at the foot of his river-stairs, in his best Sunday sulu, and shrieked to us to come up and have something to eat; of how we floated relentlessly past, like Elaine going down to Camelot, and wouldn't call; of how, at long last, we came toward the 
mouth of the river, near the open sea, and I got up on the seats, and said "Thálassa, thálassa!" (or, at least, felt like it); of how I reached a white magistrate's house, and quartered myself therein, and was hospitably welcomed, also given clean clothes, and tea with real milk in it-I cannot write in detail. Nor is it necessary to add (therefore I add it, since the superfluities of life are the only things anyone really cares to have) that Joni, Nasoni and Gideon picked up most of the guavas, and 75 per cent. of the oranges, that we met floating down the river from the trees on the banks; that they ate them, and that, furthermore, arrived at the constabulary station where they were put up, they consumed (in addition to one feast at Mavua and four coming down the river) all the tinned meat, biscuit, tea, yam and rice offered them by the Governmental authorities, as liberal rations for travelled and hungry men.

That they were ill, after all, I know; for they left me a day or so later (not in too good condition) when I hired a cutter to take me down the coast; and months afterward, I heard that "the marama had taken Joni and Nasoni away from Ba River down to the Singatoka, and they came back very sick, for she had worked them nearly to death!"

Before leaving the district, I heard that many thousands of acres of the best land in all Fiji were to be had on the Singatoka for banana-growing, tea, coffee, vanilla, or stock-raising; and that the complicated and troublesome native laws which had caused much difficulty about land tenure in Fiji were being swept away. By the time these lines appear in print, it will be possible for any desirable settler to obtain land at low prices direct from the Native Office in Suva, without any fear of offending and, consequently, living on bad terms with his coloured 
neighbours, and also without any doubt as to the security of his own title.

There is no necessity to tell how I got back to Mavua, and thence to Suva, seventy miles from the mouth of the Singatoka. There was a very rough sea, and a cutter, with a little dog-kennel forward, and a miserable creature that crouched within, for a wretched day and night. . . . But let us draw a rug over it, as I did. 



\section{CHAPTER V}

\section{PERSONAL IMPRESSIONS}

The Song of the Road-Fijian Fun-Night on the Wainikoro-The Noble Savage Fails-The Village Plate -The Lot of the Kaisi-Sharks Again-A Swim for $i$.

TORTHWARD of Viti Levu ("Great Fiji”), where I - had been travelling, lies Vanua Levu ("Great Land"), the second largest island of the group. It is over one hundred miles long, and thirty miles across. On the map, it looked interesting and easy; so I took a steamer up to Lambasa, the principal port, intending to see something of the island.

Six weeks afterward I came back, having travelled about a hundred and eighty miles in the interior; spent the best part of a month, in different slices of time, waiting for steamers; and learned, once for all, what being "off the road" really meant. Viti Levu was a mere summer's day picnic compared to Vanua Levu. Stanley (I cannot get rid of the comparison) would have liked Vanua Levu. He would have enjoyed the total absence of bridges, the fine profusion of swamps and gullies, the days when the men had to keep their knives always ready to hack a path through choking lianas, the mornings when it rained horribly, and one had to go on, and get soaked; the evenings when one had to put up in a house without any doors, each open doorway serving as a sort of operabox for a score or two of greatly excited and interested 
natives, looking on eagerly at the performance inside. He would have liked to eat ancient biscuits soaked through with rain, and thoughtfully wrapped up by one of the men in a spare sulu, only half soiled-he would have enjoyed rough-washed clothes, cleaned by himself in a river with a scrap of toilet soap-the acquirement of a permanently scarlet nose would not have grieved him as it grieved me, and I am quite sure that he wouldn't have got surly and unamiable every time it was necessary to dirty his clothes with wet red clay.

I do not apologise for writing about the mere personal impressions of this trip, because many books of travel have taught me that the modesty which omits them is mistaken. Most people like to know how a traveller in out-of-the-way regions feels and thinks; without such details, the account becomes a mere dose of undiluted geography.

There were some small risks in the Vanua Levu journey, but no great perils; many little hardships, but no starvation, fever, thirst, dangerous heat or cold. The only real difficulty was the responsibility, which, hour after hour, and day after day, lay somewhat heavily on my unaccustomed mind, new to uncivilised travel. I wanted to see and understand the resources of the country for myself, and to this end, it was necessary to select the best tracks, from data furnished by a mass of incoherent native statements, badly translated-to decide where to go, in a country where each rare white settler knew his own neighbourhood, and very little beyond-to keep my horse from breaking his legs, or getting drowned, every hour in the day, prevent my men from running away, and keep myself in good condition on a diet of tinned meat, dry biscuit, and milkless teaall these were tasks that called for a good deal of energy 
small though they might appear to those real explorers whose feats I was faintly copying, as Early Victorian ladies used to copy fine steel engravings in pale niggling pencil-work. Yet I enjoyed the trouble, enjoyed even the inconveniences, after a fashion, since they were richly paid for, in the pure gold coin that Nature mints for sailors, campers, and gipsy wanderers alone. Some need, so exceedingly deep down in the roots of humanity that one cannot even define or name it, seems to be satisfied by wanderings such as these. I $\mathrm{t}$ is a need not felt by all (though lying latent in very many who never suspect its existence, until sudden changes of circumstances call it out), and those who do not experience it find it hard to understand. Yet it is one of the strongest forces in the world-hunger, love, the lust of battle, alone can rank with it in power over humanity. The "Song of the Road"-the "Call of the Wild"-and other terms coined by an analytical generation for this nameless power, describe it more fairly than the trumpery tinsel names of the guide-books describe the miracles of the awful canyon lands of western America. But those who know what it is to come home to Earth, understand the meaning of the call, although at the very coming, she lays a cold finger on their lips for welcome, and says, "You shall know, you shall enjoy, but you shall never tell.

After the monotony of Society in Suvaafter the days under galvanised iron roofs, and the chatter about infinite nothings, and the long-tailed frocks worn in shaded, scented drawing-rooms-came the out-ofdoors again; "boot-and-saddle" once more (it hurt my sense of the dramatic unities to think that I didn't wear boots, but shoes), and again the rough, half-known 
country of the kindly brown men. Lambasa is the only oasis of civilisation on Vanua Levu, and even it consists merely of a Colonial Sugar Refining Company estate, with what Goldsmith would have called "all its busy train" of Indian and Solomon Island labourers, and white managers, overseers, clerks and mechanics. There is a store or two, also a Government Armed Native Constabulary Station, and outside, the wilderness. No roads, no towns save some Fijian villages, no white men, except single specimens at intervals of several days' ride; no regular mails, no stores, save a little shanty or two at very wide intervals, kept by Indians or Chinese. Even the native villages are far apart; you may journey twenty miles without seeing one, whereas in Viti Levu there is always food and shelter within ten miles at farthest.

Nor are the people of Vanua Levu like the people of Viti Levu. Farther away from civilisation, and less under the influence of their own chiefs, they are rougher and wilder in every way than the natives of the greater island. In Viti Levu, any native I might chance to meet on the road at once removed his headband, and laid down his bundle from his shoulder (both acts of respect), whereas, in Vanua Levu, parties of Fijians travelling along the bush tracks would stare boldly and rudely, swagger past with their head-bands in place, and even keep their bundles of food on their shoulders while passing -which, in a Fijian, is simply an act of deliberate rudeness and defiance. Nor did my men remonstrate with them for their discourtesy. A Fijian, at best, is only outwardly submissive to the white race. He is a craven at heart, and therefore easily kept down by the British rule; but loyalty to an employer is not one of his virtues. Attack from these natives was a thing barely within the 


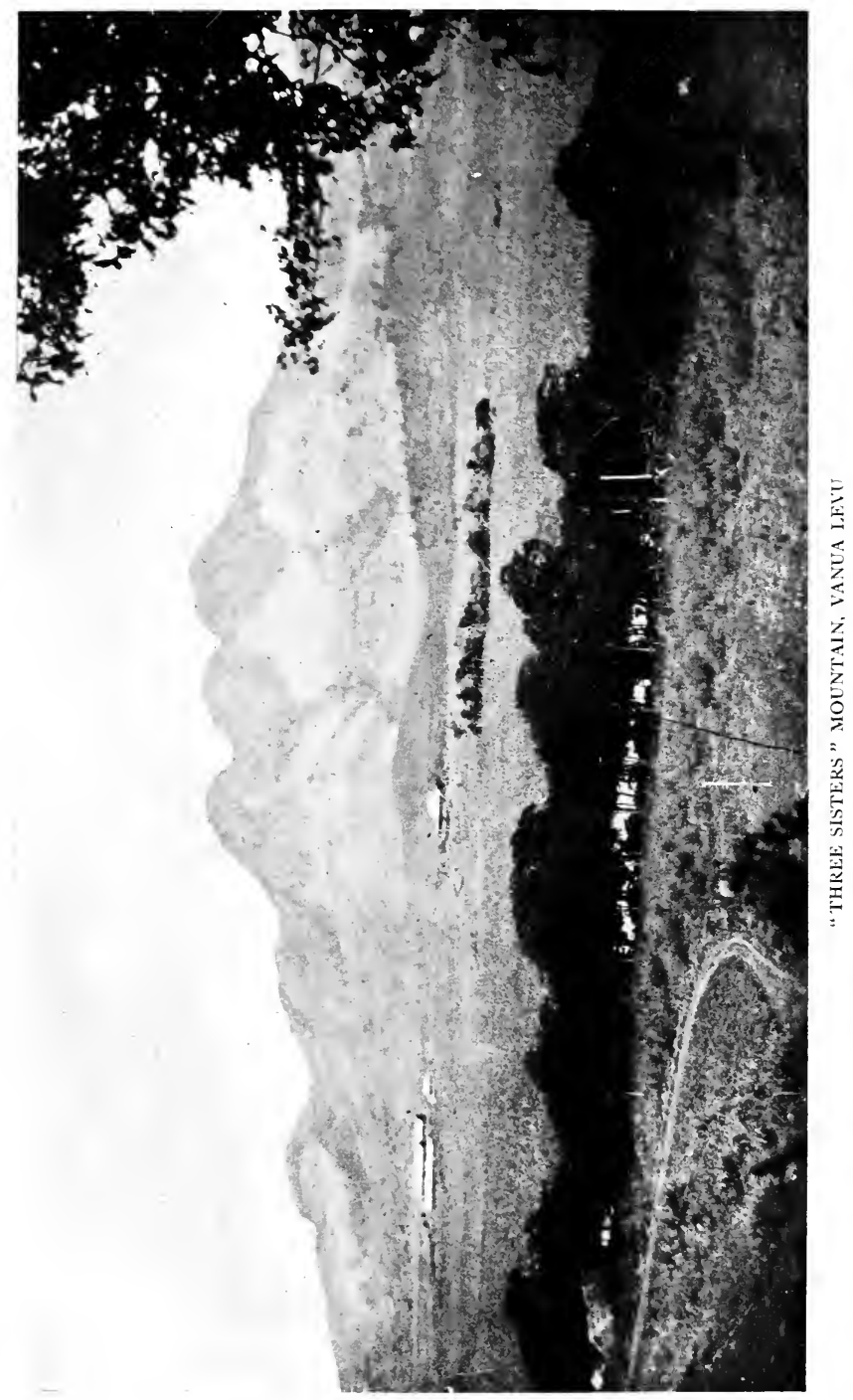




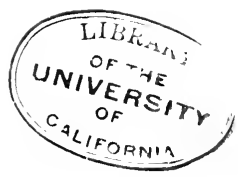


bounds of possibility, so I did not fear it; but I knew that if any trouble had occurred, my three big Fijians would simply have run away to avoid being concerned in it, and left me to see it out by myself.

Hearing that there was a good deal of excellent native land available at Wainikoro, some twenty-two miles from Vuo, where I landed, I secured a horse, and engaged a couple of carriers to accompany myself and Gideon, my special interpreter and servant, whom I had brought on from Viti Levu. The horse belonged to the local Buli, and had every vice that a native horse can have. He shied, in a manner that I can only classify as virulent, deleterious and disconnective; he bit like a rat at bay; he kicked at me one-leggedly, like a misogynistic ostrich; he was thick in the wind, didn't like hills, was afraid of slippery places, and endeavoured (apparently as a matter of principle) to wipe me off against every cocoanut-tree he met. Such as he was, however, he was the only means of travel available, so I engaged him for a few weeks, and trusted to time and care to improve his manners. The men named him "Somosomo," and always addressed him by his title. I asked what it meant, and they told me, "Fiji flower, plenty good flower" - which led me to infer that either their knowledge of horses was small, or their charity large; for if Somo-somo was the flower of Fijian horse-flesh, it did not say much for the remaining steeds of the colony.

The Flower did not like my side-saddle, first of all; secondly, he entered a protest against that unexpected outrage, my riding-habit; and thirdly, he objected very strongly, in gross and in detail, to myself. These prejudices having been overcome in some degree, and a start made from the hospitable house where I had been entertained on my arrival, we got on our way to Wainikoro. 
The chiefs of Vanua Levu would not allow their men to go away for more than a few days, so (as a Buli, or chief, has power over all the men in his district, and none of them can leave it without his permission), I had several different sets of carriers during my journeyings, instead of keeping the same men right through, as in Viti Levu. This was not so good a plan, as the men were making less money, and were therefore much more prone to desert me, and to lag carelessly behind, over country where they could easily have beaten my horse. On the way to Wainikoro, I saw little of them, except at meals. There was no question in Vanua Levu of the demoralising Capuan luxury that I had experienced on the Singatoka. Villages were far apart, and poor, and though the contents of my purse obtained sufficient food for all, there was no superfluity.

Half the day's journey to Wainikoro lay through "The Company's" fields of bright-green sugar-cane. Afterward, we came into woods beautiful as all the Fijian forests are, and most pleasantly cool. The track was about a couple of feet wide in most places, and so steep that a good deal of walking had to be done. Gideon was in his element, with a new audience for his boastings and braggings about me. I caught odd fragments of conversation, as we journeyed on, that told me my social status was increasing. In Viti Levu, I had merely been an intimate friend of King Edward's. Here I was an "Andi," or princess, according to Gideon: I had bags full of gold, and a hundred boxes of clothes in Suva-he had carried them up from the steamer himself. I was such a great lady that I lived on tinned meat and biscuit every day, and constantly had tea with sugar in it, and I was splendidly generous, as befitted such a personage; for every now and then I would give 
as much as sixpence to buy tobacco for the men (Fijian tobacco, of which one gets a good handful for that sum), and I often gave away whole quarter-pounds of sugar, just to eat as they liked. I had a revolver that would kill twenty men at half a mile, and I had fought all through the Boer War (in which struggle the Fijians took the warmest interest), shot hundreds of Boers, and cut their heads off afterward. . . . With these and other fictions did my henchman entertain the gaping carriers, who evidently swallowed every word and, in consequence, respected their informant all the more, in that he was privileged to be the servant of such a celebrity.

I was not sorry that the men stayed out of sight a good part of the day, for I could enjoy the beauty of the scenery better when quite alone, and it certainly was very lovely. Once the track broke suddenly out of a grove of feathery ironwoods into the staring sun, and dipped downward toward a wide green plain bordered by brown and purple hills, with just one line of distant mountain peaks rearing their blue battlements on the horizon. . . . Only a range of mountains, covered with reeds and forest here and there, rough and uninteresting, no doubt, when one reached it, with ups and downs and gullies and thickets just like the ground about my feet, and yet . . . And yet, if I could write all that those distant summits said to me, as they lay sleeping in the still yellow light of the waning afternoon-all that the eternal hills, far away and blue and utterly out of reach, have said to countless souls since the beginning of time-I should speak with the tongues of men and angels, and tell what human lips have never told, and never will.

I turned the horse down into the valley, and soon 
the woods shut in the path again. But for long after, as I rode through the quiet forest, with no company but the murmuring hill-river at my side, two lines from some half-forgotten poet kept chanting in my mind, sadly, as befitted the lonely land and the waning day:

\section{“. . . The heights of heaven \\ Where I shall never win."}

Sunset was near, and sunset, in these latitudes, means dark. I waited for the men, and told them they must hurry. It was well that I did so, for we came soon to a place where the track disappeared in a bog, and "Somosomo" had to be coaxed and driven over the narrowest part, where it was quite safe for him to cross, although he could not be induced to see the matter in that light at first. After ten minutes' dragging and yelling and beating, he was compelled to make the attempt, and landed safely on the opposite side, not without a flounder or two that made me glad I had had the sense to dismount. Then one of the carriers opened a window into that strange storehouse of contradictions and oddities, Fijian character, and showed me the queerest curiosity it had yet furnished-a specimen of Fijian sense of humour. $\mathrm{He}$ had watched the horse being got over with a perfectly grave countenance, but as soon as it was fairly across and I was mounting again, he went to the side of the track, carefully picked out a soft piece of grass, laid aside his load, and, flinging himself down on the ground, began to roll and kick and screech with a mad, violent, almost terrifying laughter, that surpassed any effort in that direction I could have imagined in my wildest dreams. That any human being could laugh like that, and not kill himself, was in itself a most astonishing thing. $\mathrm{He}$ choked, he crowed, he howled, he let out wild, eldritch 
yells that woke all the echoes of the black, sinister valley along which we were travelling; he lay on his face and kicked, he lay on his back and writhed, he gave himself over body and soul to a very devil of laughter. And, at intervals, he screeched, in a voice half choked with cackling; "The horse wouldn't go over. It wouldn't go over."

It took some time before I realised that I was merely witnessing a Fijian struck with amusement, not a man dying in a fit. When I did realise it, I called him a commoner of the fourth degree (which is Fijian vituperation), and told him to get up and come on. But I have never yet been able to make out where the fun came in.

I had brought no watch on this journey (having unluckily lost mine overboard from a ship, a little while before), and I had been trying to learn to tell the time by the sun. It sounds simple enough, until one attempts it and then one discovers that even in tropical latitudes the sun is not exactly in the centre of the sky at noon; also, that it seems tc travel much faster at the beginning and end of its journey than in the middle. After a good many day's practice $l$ found myself able (judging by the sunset, which was about six o'clock), to tell the time within half an hour or so; but I never got any nearer. As for the natives, they have extremely little knowledge of time in any case, and are never troubled at the prospect of being benighted on the road. That, again, is "the white man's burden," not any business of theirs.

We did get benighted on this occasion, and extremely unpleasant it was, trying to bring Somo-somo safely over the various bad and boggy bits in the dusk. Dark had fallen by the time we reached the Wainikoro River, which I knew to be near the town-and behold, there was not a sign of a human being, and no boat! 
A lovelier spot I had never seen, even in beautiful Fiji. There was no moon, but the wonderful tropic starlight burned in the purple sky with such a clear radiance of its own that the wide glassy river, edged with feathered reeds, the splendid palms, lifting their dark coronets eighty feet up among the stars, the orange-trees on the further side, dropping their juicy globes now and then into the waveless mirror below with a dull, dead-ripe splash, all were plainly visible. It was like a daylight scene viewed through a piece of deep violet glass. The stillness was intense; the palm-trees on the banks stood motionless as ebony-coloured plumes on a catafalque; the black river moved by without a ripple. A spot where one could have dreamed and wondered for hours; where Oberon and Titania, in the magic starlight, might have.

"Sa senga na kakana, saka" ("We have no food, sir").

A Fijian has no poetry in his soul-especially if he has also nothing inside the most vital part of his mortal machinery. My poetical musings were scattered at once, and I came down to the plain prose of night, hunger, an impassable river, and the men wanting their supper.

We had only a few biscuits left-the tinned meat was unavailable until we reached a town, as none of the men happened to have a knife. (I don't think Speke or Livingstone would have forgotten the tin-opener, as I did.) I gave out the biscuits, reserving rather less for myself, in the dark, as I knew my hunger was more easily satisfied than theirs; but the men seemed to guess what I was doing, and gave back part of their share determinedly. A Fijian woman would have had to manage with the scraps they left; a white woman was as good as a man to them, and men must share equally.

We could do nothing but wait for a native to pass; so the men made a fire to keep the mosquitoes off; walked 
up the cocoanuts like flies, and threw down half a dozen green nuts, husked them on a sharp stick stuck in the ground, opened them, and handed them about. Then they lay down about the fire to eat and drink, while I walked up and down the river bank, waiting for a native.

It seemed as if no one was likely to come; but after half an hour or so, I heard a crackling in the woods on the far side. The noble savages ought to have heard it before I did; but they never noticed it, being intent on sucking cocoanuts, and when I pointed it out, they said it was probably a pig. When the dark form of a native, very slightly clad, appeared like a slim shadow on the opposite bank, I called the men up again, and pointed across. "That is not a pig," I said. They laughed; and one more delusion about the "noble savage" vanished from my mind. If he couldn't tell the time by the sun, never knew when it was going to rain, and did not know a man's footstep from a pig's, it seemed to me that he was not fit for his part, and ought to be hissed off the stage.

Gideon, at my direction, yelled to the man and asked if there was a boat or a canoe. No, there was neither. They had a canoe, but it was away up the river, and wouldn't be back till to-morrow. The men laughedthey always did when we came to a dead-lock-and sat down at once to smoke. I hustled them up again, and told them to unsaddle Somo-somo, and lash a few sticks together to put my luggage on. We should have to swim for it.

They did as they were told, and I went down to the river's edge to reconnoitre. I tasted the water-it was brackish. Now, if there is danger of sharks high up in the Fijian rivers, there is very much more close to an estuary. I did not like it.

"Ask that man if there are any sharks," I told Gideon.

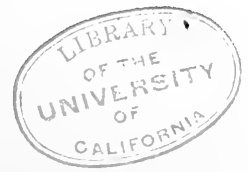


"No shark stop!" he replied confidently. As neither he nor the carriers had ever been within twenty miles of the river, and as Fijians are absolutely reckless about sharks, I did not set much value on his remarks, but called over to the native on the far side, in rather bad Fijian:

"Sa senga na ngeo?" ("Are there any sharks?")

Instead of the loud, comforting "Seng'ai, saka" ("None, sir") which I hoped for, came a complicated reply I could not translate. Gideon's version was: "He say sometime shark he stop, sometime no stop."

This was not good enough. Facing the astonishment of the native, and the amused scorn of the men, I declared I would not swim; that they must get the canoe; that I was a great chief, and would assuredly kill somebody if the Wainikoro people didn't go and capture that boat, and bring it along, alive or dead-and other things to the same effect. The men's amusement at my fear of sharks broke up into fright, and they yelled to the native to get the canoe-get anything-for this was a terrible marama (lady), and there was no knowing what she would do unless pacified.

There is no power on earth like that of ill-temperreal or manufactured. In an hour's time, the canoe appeared, and Gideon hastily packed my goods and myself on board. Across the Wainikoro we went, followed by the small, meek, dripping head of Somosomo just above the water, and in another half-hour I was installed in the usual native house, with the usual gaping crowd at the doors, and the usual fowl and yam preparing. Fowl is the one thing that a Fijian eats off a plate, instead of a leaf. He does not care to lose any of the precious water it was boiled in, so he always serves the murdered bird on a tin plate, which in many cases 


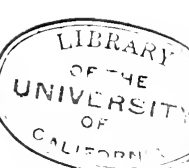




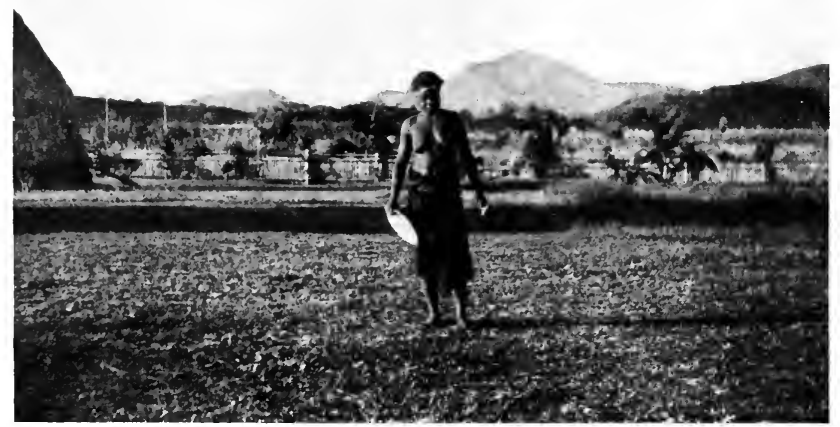

THE VILLAGE PLATE

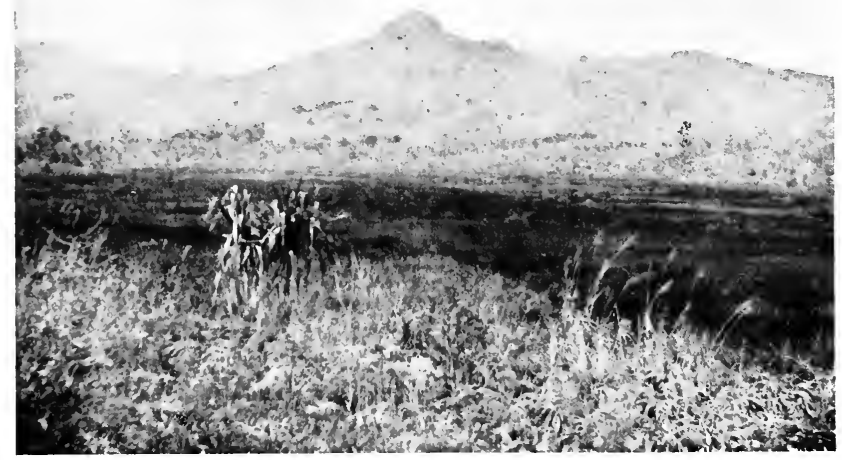

UNPEOPLED COUNTRY 
belongs to the village at large, and is sent about from house to house, whenever a feast is in progress. There was the usual fuss about hunting up the village plate while the food was preparing, and at last it was brought triumphantly in. Next morning, as I left, I saw it being hurried to the native teacher's house, by which I concluded that godly men from another village were expected, and entertainment was being prepared for them. Yam and ndalo are the common food of the people, fowl and pig being rare luxuries, except among the chiefs. In these days, the British Government keeps some curb on the exactions and tyrannies of the native rulers, and they cannot treat the "kaisi," or commonalty, as high-handedly as of old. Yet, even so, the lower classes live plainly and poorly, while the chiefs annex everything that takes their fancy, in the way of food, order the "kaisi" about like dogs, and compel them, as a matter of course, to work for their superiors without pay. In Vanua Levu, which is nearly all wild unbroken country, with very few white residents, I saw Fiji in the rough, and it did not seem to me that the lot of the kaisi was at all a happy one. Thirty or forty years ago, their chiefs could slay them at pleasure. Now they must respect life, at least; but the kaisi is not allowed to have a soul of his own. He cannot leave his village without the chief's permission; he must work without pay as much as his superior desires, building houses or boats, or cultivating the communal patches of yam and ndalo. Ambition is impossible to him; born a kaisi, he must remain one, and cannot hope for improvement in his lot. Something of this is reflected in his ways of living and even his expression of face. In the other Pacific groups I have visited, a village at dusk is bright and merry, sounding with music and laughter, and full of lights. In 
Fiji, the towns are dark and silent at night; there is little singing, and the amusements are of a quiet kind, cardplaying and yanggona-drinking being the chief. The Samoan, the Tongan, the Tahitian, or Cook Islander lives for pleasure and amusement-picnics, travelling parties, continual dances and songs, games of every kind enlivening his day and night. Chiefs, in these other groups, are less oppressive, and the communal system, with its care for the tribe, and harshness to the individual, is much less strictly carried out. But in Fiji, the kaisi has not much heart to invent games and amusements. He can be a jolly fellow enough in his own way; he is exceedingly good-natured, readily pleased, and delighted with a joke. Still, at bottom, he has a spring of darkness and melancholy that is ever ready to rise and overflow the surface sunniness. His fathers lived lives of gloom and terror, always under the shadow of the war-club and the braining-stone, and within sound of the terrible "lali," or death-drum. When a chief died, the kaisi were slain in dozens, and thrown into his grave, because-“"a chief must have grass to line his tomb, so that he may lie soft." When a war-canoe was launched, it went down to the sea over hundreds of writhing human bodies, whose life-blood stained its keel, and whose death-yells sped it on its way. Living men were placed in the holes that received the supporting pillars of every chiefly mansion; human bodies, frequently alive, were daily forced into the red-hot cooking-ovens that supplied the meals of the chief. What wonder that the shadow of these hideous days - which can yet be remembered by the older menshould still rest upon the younger generation?

I left Somo-somo peacefully grazing at Wainikoro next morning, and went off to look at a stretch of country immediately beyond, which I had been told was good 
land for planters. What I saw was a patch about four miles long, and apparently not much less in width, composed of low, grassy flats, and pandanus prairie; all natural land, but practically cleared. I heard that there was a good deal more of the same kind further along the coast. No one could tell me what the probable rent might be, but it could not exceed a very few shillings an acre.

Next day, the horse was saddled early, but we could not get away at once, as one of my men had gone off to a meké-meké in a neighbouring town, and had to be fetched. It was well on toward noon when we got to the river again - a few hundred yards higher up this time but, nevertheless, at a spot where it was wide and deep -and found that the canoe had been taken away again! It was irrecoverably gone this time-gone out to sea on a fishing excursion, sure to last till next day at leastand there was not even a raft to be had.

Could not the men make a raft? I asked Gideon.

Gideon, indifferently chewing sugar-cane, said there was no bamboo about here. Could they not make one of anything else? Gideon was not much interested; did not think so, sir; didn't know what they did when they wanted to get things across the river dry. Did not know anything. Obviously wanted to sit down and smoke.

With the calmness of despair, I extracted my swimming-dress from my box, and went off into the wood. Returning clad in "rationals" and a cloak, I told Gideon to follow me with my goods, and to keep them dry, somehow, anyhow, on pain of frightful retribution. Then I left the cloak on the bank, waded across the shallows, feeling unconscionably cold and shaky, but assuring myself that I wasn't a bit afraid, and plunged into the fifty yards' stretch of deep water. 
I never swam like that before; I never shall again. Imaginary sharks chased my horribly conspicuous red swimming-dress and white English skin right up to the bed of greasy mud on which I landed. I was half up the bank before I remembered that my clothes were on the other side, and that Gideon in all probability would rather die than bring them to my side of the river, since it is strictly "taboo" for a Fijian man to bathe at the same time as a woman. So I sat in the mud, and screamed to a native woman who was watching the proceedings from the farther shore; and she (having no fear of sharks, as I, miserable craven of a "papa-langi," had), put my things on her head and came over at once. And I took them into the bush and dressed, reflecting that Cook would have made a raft; La Pérouse wouldn't have minded the sharks, and Sir Samuel Baker would never, never have forgotten to tie his clothes on his head before he started across.

So, very humble, I mounted Somo-somo, who was steaming and dripping in the sun, and rode away, back to civilisation, as represented by the solitary house of the kindly white magistrate and his wife, who had entertained me at Vuo. It was a long day's ride and a pleasant, and never, while my mortal frame hangs together, shall I forget the wild pineapples that the men discovered beside the track in a baking, sun-smitten little valley. We were all hot and thirsty, and the fruit, though it was as warm as if just taken out of an oven, was delicious -rich, wild-flavoured, and so juicy that the men and I had to go back to a stream and wash, after eating a pineapple apiece-with one over for Somo-somo, who sturdily begged for his share.

I heard afterward that the Wainikoro River certainly had sharks, and that recently, just below the spot where 


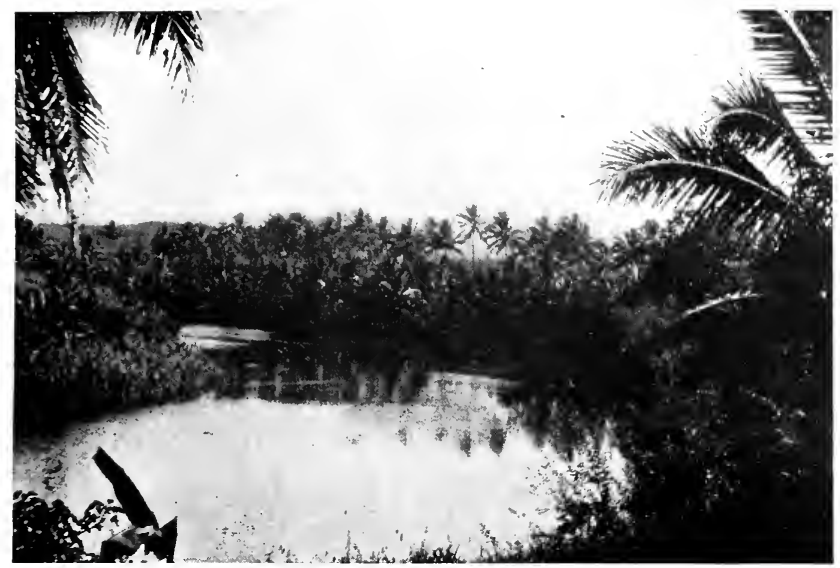

THE BOATLESS WAINIKORO

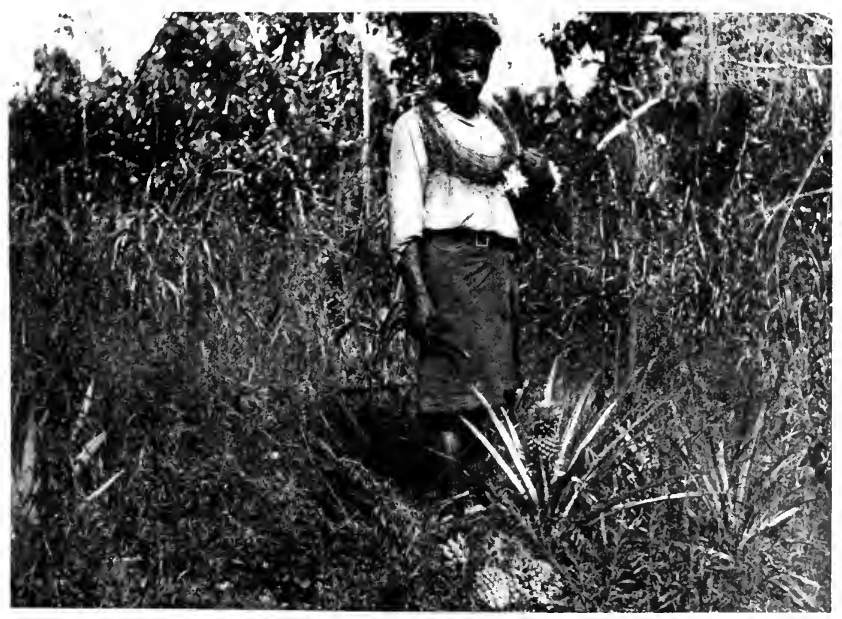

THE WILD PINEAPPLES 
울 
I swam across, a native man and woman, crossing with a dog between them, had seen the dog taken down by a shark before their eyes. It is well known, of course, that brown or black people run much less risk from sharks than white; which may explain the stolidity of the Fijian mind regarding these horrible creatures. The river-sharks are not large-only six to eight feet, as a rule-but they are quite capable of biting off a limb, or inflicting a fatal injury. 
. 


\section{CHAPTER VI \\ CONTRASTING SCENES}

Off to the Ndreketi-Fijian Smart Society-A Native Princess-The Sugar-cane Dance-Getting BoggedThe Use of Bad Language-The Ndreketi RiverA Splendid Timber Country-A Native DiaryTruth about Tropical Forests-How to Live on Nothing a Day

$T^{H E}$ next trip I decided to take in Vanua Levu was 1 a much longer one-up the Ndreketi River, and into its forests, to see the timber country. The river was only about fifty miles from my starting-place-a two days' journey, if the tracks had been good--but it took me four days' travel to get there. Only thirteen miles could be covered the first day, because of a tidal river, that had to be crossed late in the afternoon or not at all. Tambia, my stopping-place for the first night, can be cordially recommended to all future travellers as an excellent place to let alone. We came in at dusk, and were at once surrounded by the usual crowd; but it was not a pleasant crowd on this occasion. Nearly half of them seemed to be suffering from unpleasant skin diseases. One or two were scaly like fish; several were marked with horrible Fijian "thoko"-a disease that shows itself in flat, button-like eruptions, turning byand-by to formidable sores-some had open ulcers, all black with flies, on arms and legs; and not a few were generally sick and decrepit-looking. Their clothes- 
-only a loin-cloth apiece-were unspeakably dirty, and every unoccupied moment seemed to be spent in hunting through each other's huge frizzled heads for certain small game; which, when found, were immediately eaten by the finder!

This unsavoury gang pointed out the Turanga ni Koro's house, and I entered by the side door; the men, as befitted their low estate, going in by the door at the gable end. This, as I have said before, is an important piece of etiquette in Fiji, the side doors of the houses being strictly reserved for chiefs and distinguished visitors. Even at the present day, a kaisi who entered by the side instead of the gable door, would probably be thrown out again with considerable violence, and in old times he would certainly have been clubbed.

The chief of the town was not in when I arrived. I let the men put down my baggage, and seated myself on the "tabu kaisi" mat (forbidden to commoners), which the women at once spread at the upper end of the room. The house seemed to be clean, but I did not like it. It smelt close and heavy - a faint yet curiously revolting odour seemed to cling about everything in the place. I could not make out the cause, nor could I call up any recollection of a similar smell, even from the varied experiences of the last few months. I wondered greatly, but my wonderings soon came to an end, for the Turanga ni Koro appeared in a few minutes, and limped across the floor to welcome me, leaning on a stick. His foot, half hidden by a rough scrap of bandage, was almost dropping off ; the bone was visible, and the odour.

"Gideon!" I said, turning to my indolent headman, who was lying on the floor, chewing sugar-cane.

"This man got leprosy!"

"Huh?" 


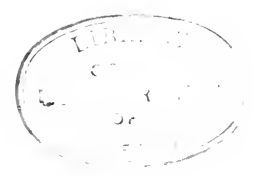




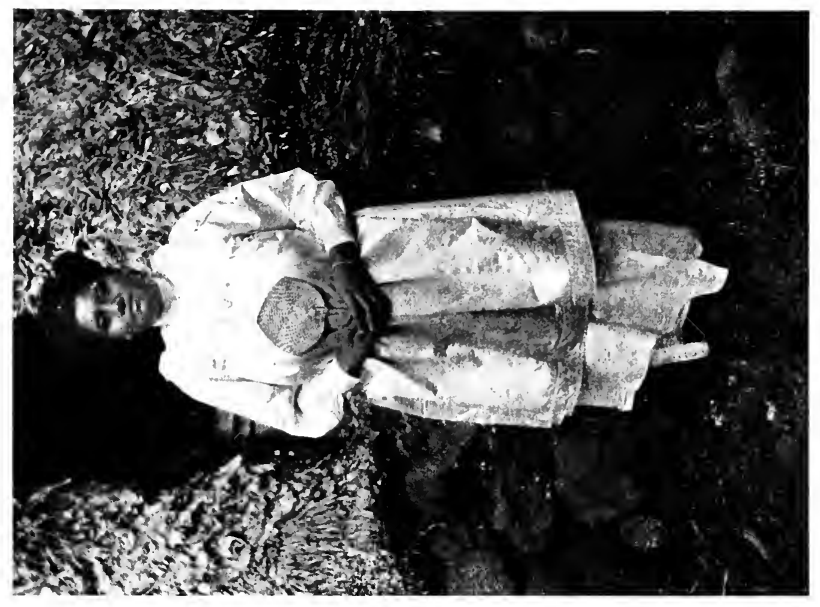

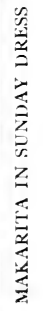

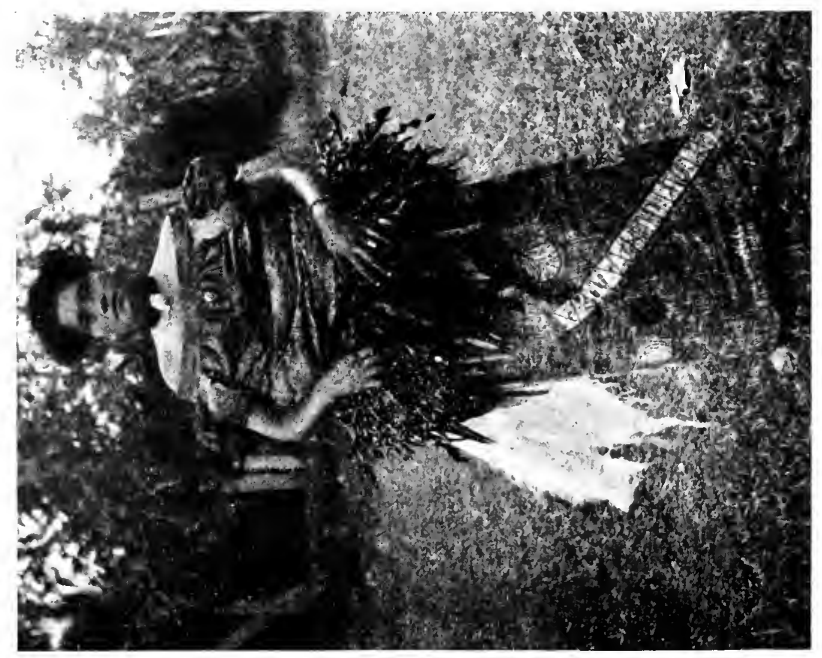


"This man leper?-all same sick Indiaman, Suva?"

"Yes, sir. All same," replied Gideon, taking another plug of sugar-cane. He had seen cases of leprosy among the Indians in Suva, and I knew he was almost certainly right. That anyone could object to a leper as a host and entertainer did not, however, enter into his view of life. The Fijians are absolutely reckless about such matters, and cannot understand the meaning of infection, which, like the sceptical American farmer's wife, they take to be merely "an idee in folk's heads."

I was sorry for the man, and still more sorry to hurt his feelings, as I knew I should do, in leaving his house; but leprosy! the mats and dishes and bed belonging to a leper-the floor over which he trailed that fearful stump. . . ! No, it was impossible!

I told Gideon to inform the chief that I could not possibly stay in the house, because of his sickness, although I was very sorry to leave it. Gideon told him, and the chief, sitting on the floor, bowed his head sadly, and said in a low voice: "Savinaka!" ("It is well!"). I got up and retired, with a few incoherent politenesses; the men turned a small, passably clean family out of another house, and I slept fairly well, enveloped in my closed mosquito-net of fine lawn, till morning. Needless to say, I was very early indeed on the way again.

Nanduri, ten miles further on, should not by rights have been a stopping-place; but who could have resisted it, especially after Tambia? A big, handsome town of several hundred inhabitants was Nanduri, with a wide, grassy main street, and clusters of the prettiest little houses imaginable running away all round it to hide themselves in clumps of orange, palm, hibiscus and flame-coloured crotons. The Roko Tui Macuata, or Prince of Macuata, lived here, also a few minor chiefs. 
The tone of society in Nanduri seemed as high as in Tambia it had been low. Clean clothes were the rule; nearly all the men and women had shirts and "pinis"; there was no visible skin disease, and the town actually enjoyed the luxury of water laid on in pipes from the river above! The white magistrate who ruled over that district had had the pipes laid down, on one of his periodical visits; and the people had taken very kindly indeed to the labour-saving arrangement of stand-pipes all along the street, and a shower-bath on the largest green. This latter was in constant use all day long, the natives delighting in the cool cataract that descended from a perforated disc overhead, at the turning of a tap. The publicity of its situation did not, of course, embarrass them at all, but they had some glimmerings of European ideas and customs in such matters; and therefore, for sheer style, they had enclosed the shower-bath -with a bird-cage of bamboo bars!

The Roko was away; but his wife, Makarita, received and entertained me right royally, giving me the largest of the Roko's three fine houses to stay in, feeding me on fowls, pork, and the best of river-crayfish during the whole of my three days' stay, and organising various meké-mekés for my entertainment. Makarita's marriage, which took place only a year or two ago, was quite a pretty little romance. The Roko is neither young nor lovely, but he is a prince, and therefore should, by rights, have married into some branch of the Thakombau family - the descendants of King Thakombau, last monarch of Fiji, under whom the 1874 cession of Fiji to Britain took place. Indeed, a suitable lady had been selected, and the Roko was thinking it over, when he happened to meet Makarita, a girl of good but non-royal family, and a great beauty, after Fijian fashion. He fell in love 
with her at first sight, and shortly married her, against the wishes of all the Fijian "smart set," and the open remonstrances of his own district. The marriage has proved a happy one, and the "beggar maid" fills her position as King Cophetua's partner with dignity and grace. I photographed her in three costumes-mekemeké dress, with mats and arrowroot-fibre kilts wrapped round her into something very like a crinoline, and cocoanut oil all over her body; ordinary day costume of brown cashmere (and very good cashmere at that); and "best dress," composed of a pink satin "pini" or tunic, sulu of white-brocaded silk, gold locket set with pearls, and long gold chain. Shoes and stockings, of course, she never wore, and her thick, stiff hair was trained upright, clipped and neatly bevelled off at the edges, in native fashion.

The wretched Somo-somo seemed to be a little sick; Gideon had been kicked by him, and was rather lame; Nanduri was exceedingly pleasant-and so I stopped three days, much to the delight of the men, who "went out" a great deal, in this fashionable town, and enjoyed themselves exceedingly. There were card-parties, where euchre and whist were played with furious excitement from eight o'clock P. M., until three A. M.- - stakes nothing but the glory of winning. There were yanggona parties, where the men met to drink, and talk, until daylight and paralysis of the legs (the effect of excess in this drink) set in together, and they had to be propped up against the wall, still talking, while the women fed them with roasted bananas to drive away the effects of the orgy, and enable them to walk home. There was a dance one night at a town two miles away, which simply cleared out Nanduri; and there were also daylight meké-mekés, performed for my amusement by the boys of the town. These last were the only festivals I witnessed, for Makarita 
politely warned me that the other entertainments were "no good for me," and I took the hint, and remained at home. It is unfortunately true that festivities got up by Fijians are not, as a rule, possible for any white woman to attend, as they usually end in indescribable orgies.

The passion for card-playing common to Fijians of every class set me wondering what the result would be if any one introduced bridge to the natives of these islands. Judging by what I know of them, I should suppose that it would sweep like a devastating plague over the country. Work would be at a standstill, and sleep and food would be taken only in snatches, while the natives gave themselves up heart and soul to the new game. They are excellent card-players, and they know no medium in their amusements-witness the law that had to be passed shortly after the introduction of cricket to the islands, forbidding the game to be played except on certain days of the week, because the Fijians had taken to it so ardently that they would do nothing else.

The boys' meké-meké was both pretty and original. A number of very bright and attractive little brown lads dressed themselves up in white sulus, and armlets of red and white flowers. They then commenced a clever pantomime dance, singing as they danced, to keep time. I was told that it was the "Sugar-cane meké-meké," representing the growth of the sugar-cane. In the first figure, they all squatted low on the ground, shaking their heads, with shut eyes, and murmuring slowly and softly an unintelligible sentence that sounded like "Eratchikéveechi, eratch-kéveechi!" Gradually they all stood up together, growing taller and taller, and as they grew, they waved their arms, and trembled all over from ankle to crown, like the tall tasselled canes waving in the wind, and still they kept on chanting, louder, faster with every 


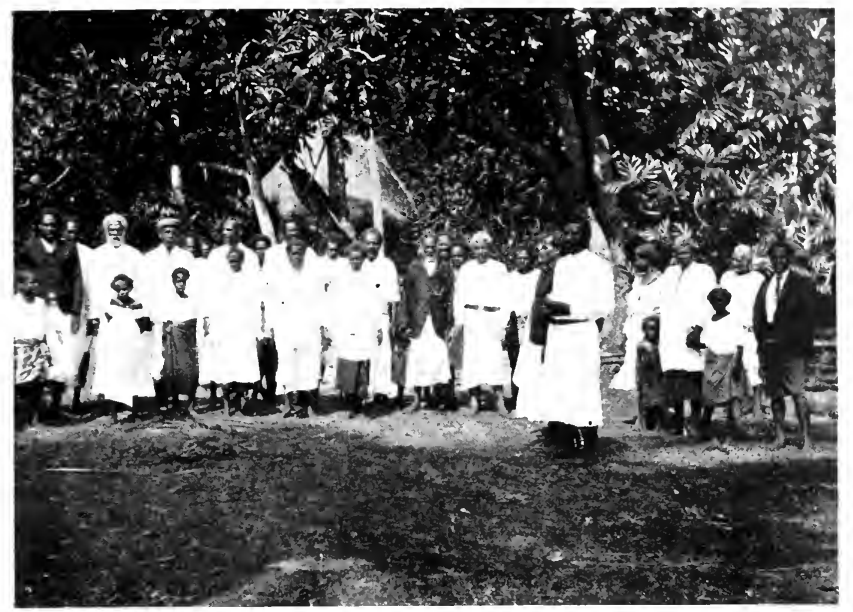

SUNDAY MORNING IN NANDURI

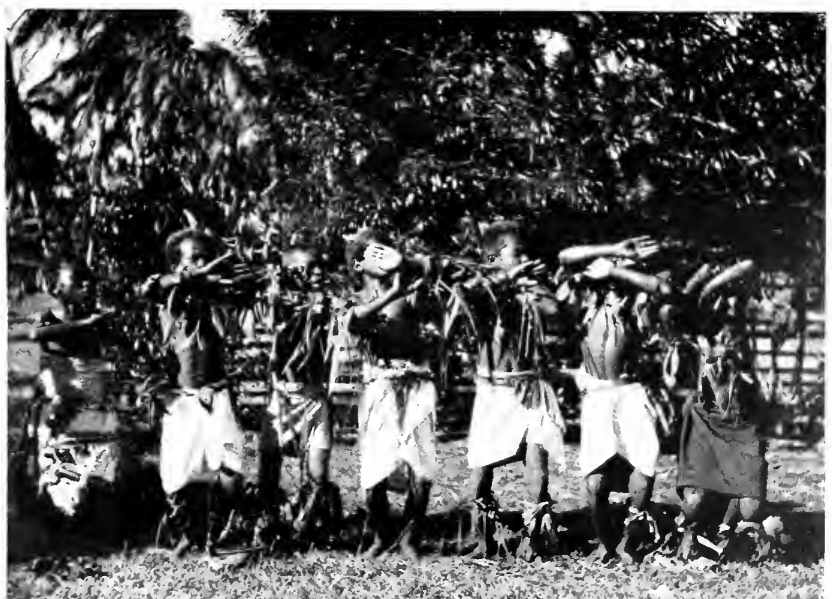

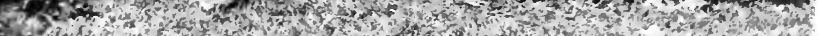
THE SLGAR-CA.IE DANCE 


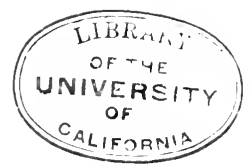


figure: "Eratchi-kéveechi, eratchi-kéveechi!" There were several figures that I could not make out, for want of proper interpretation, but I succeeded in understanding that one figure, which represented a series of hearty fights (and nearly broke up the dance, through the fervour displayed by some of the little actors), was meant to picture the exactions of the chiefs, who compelled the "kaisi," willing or unwilling, to come and cut their crop.

When the dance was over, I gave the boys some biscuit and tinned salmon, and left them amicably sharing the small gift with at least forty friends, Fiji fashion.

Nobody wanted to leave Nanduri, myself least of all; but the Ndreketi was far ahead, and Somo-somo was well again; so a start had to be made. Away in the slanting early sun I rode from the pretty townaway from all comfort, all decent food, all safe roads, all kindly natives, and, apparently, from all good luck as well. I lost my purse the first day, and though an honest youth from a half-caste village (a curious spot, that village, if I had time to write about it), found and brought it back, later on, the loss caused delay and vexation incalculable. Two days' hard travel it took to cover the thirty miles between Nanduri and Tumba, on the Ndreketi. The first day, Gideon all but hanged Somo-somo by tethering him with a slip-knot. The next day was a series of perils for the unlucky brute, and anxiety for me. If I had known all that lay ahead, assuredly I would have sent him back, and walked, but the misleading accounts I got of the country ahead induced me to push on. There was no road, no real track even. We travelled by bare indications in the shape of crushed branches or trodden grass; smashing through miles of liana-knotted bush by the aid of knives, struggling through marshes, scrambling up and down hills as steep 
as a house-roof, and slippery as butter, and worst of all -encountering streams every mile or so. Every stream or river was at the bottom of a perpendicular gully with greasy clay sides, down which the protesting horse had to be pushed and dragged, while I walked over on a cocoanut $\log$; some of them were deep and rapid, and many had dangerous bottoms of soft clay. And now, after a fashion that was exceedingly unpleasant, came my opportunity of learning what the people up in Lambasa had meant when they warned me:

"Don't get your horse bogged!"

It does not sound very alarming, and I had supposed that "getting bogged" was merely a case of floundering into a soft bit, a rapid dismount, and a dirty habit, while the horse got over by himself. Alas! it was considerably more.

I had just dismounted to let the men lead the horse down a gully that looked much like those we had passed, and was scrambling up the far side, after crossing on a log, when I heard a terrified yell from Gideon: "Missi $\mathrm{N}$-grimshaw! Horsie lie down, by-n'-by he n-dead!", Turning round, I saw poor Somo-somo, having missed the jump at the bottom, plunging and struggling madly in the gully, which was filled with treacherous mud. He had already sunk up to his belly; his eyes were starting from his head, and he snorted fearfully through his dilated nostrils, in the very extremity of terror. The men hauled helplessly on the reins, screaming at each other, and shaking with nervousness; it was clear enough that they thought the days on earth of the poor "Flower" were ended. They were perfectly useless, and I had never seen a horse in such a plight, and had not even heard what ought to be done. The banks were hopelessly steep; it was not far off dusk; the nearest village where 
help might be obtained was two hours away-and all the time, poor Somo-somo, whom I had really grown fond of, was dying a horrible death, staring wildly at me in vain hope of help, and breathing now in long-drawn, painful snores of agony. . . . I would have given twenty pounds for liberty to sit down on the bank and go into hysterics. If there had been anything human with a head on it about, I certainly should have done so, for the sight was indescribably painful, and the feeling of helplessness still worse. But my three men were three children of Nature, which meant three useless babies in trouble of any kind, and Somo-somo's life hung on me.

I told one of them to take a stick at once, and test the depth of the mud. The horse had now sunk to half-way up the chest. Fortunately, the test revealed that he had touched bottom, and would go no further. The danger, however, was none the less, I knew that he might struggle himself to death, and guessed that his head would sink when he became exhausted. As for the men, they were squatting down to their eternal cigarettes, quite prepared to watch the horse die, and, with true savage cruelty, to laugh over its expiring struggles as an excellent show.

"Horsie he n-dead, by-n'-by," was all the answer I got to my orders, when I told them to get up and try to help.

. . Then I lost my manners. It does not matter what I said. There is a kind of English that every Fijian understands and obeys. I gave them that English, reproducing it phonographically from my recollections of the sort of thing the South Sea Islander mates used to say to the cargo-workers on the quays. I missed the real style of it, no doubt, but what I gave them was the 
best I could do, for a first attempt, and it seemed to touch the spot. They got up and went to work.

I told them to haul on the head-rope, and lift the horse's quarters with saplings. I made them cut down a considerable section of bush, and fling it wholesale in front of the poor "Flower." I compelled them to batter down the perpendicular bank of solid clay, and cast it on to the sticks and boughs, at the same time making a practicable exit. I worked them like mules for over an hour, and scolded like a turkey-hen all the time. At the last, a piece of fairly solid standing-ground was manufactured, and Somo-somo, filthy, exhausted, terrified and trembling, got out with one final struggle, and stood on the bank, swaying on his feet, and looking like death. But he was saved.

There was a long walk through the twilight and the dark then, and a big, unseen river-the Ndreketi at last-to cross in the starlight, carried almost on the necks of men who were walking shoulder-deep. In a strange, dim valley, half a dozen natives started up out of nowhere, and offered me food-bananas, cocoanuts, odd little packets of porridge, made from ndalo roots, sugar-cane, and cocoanut cream, tied up in green leaves. I took it thankfully, and Somo-somo, who had been walking behind me, relieved any fears I might have had about his recovery from the late accident, by suddenly projecting a yard or two of dirty neck over my shoulder, and grabbing the biggest packet of porridge for himself. He was always well fed under my care, but his manners, none the less, were those of a shameless buccaneer.

The welcome sound of a white man's voice, calling out of one of the endless gullies, told me at last that I had reached the neighbourhood of the little settlement I 
LIBRARi

OF - $4 E$ UNIVERSITY $O F$

$C_{A L \text { IFAnOHI }}$ 


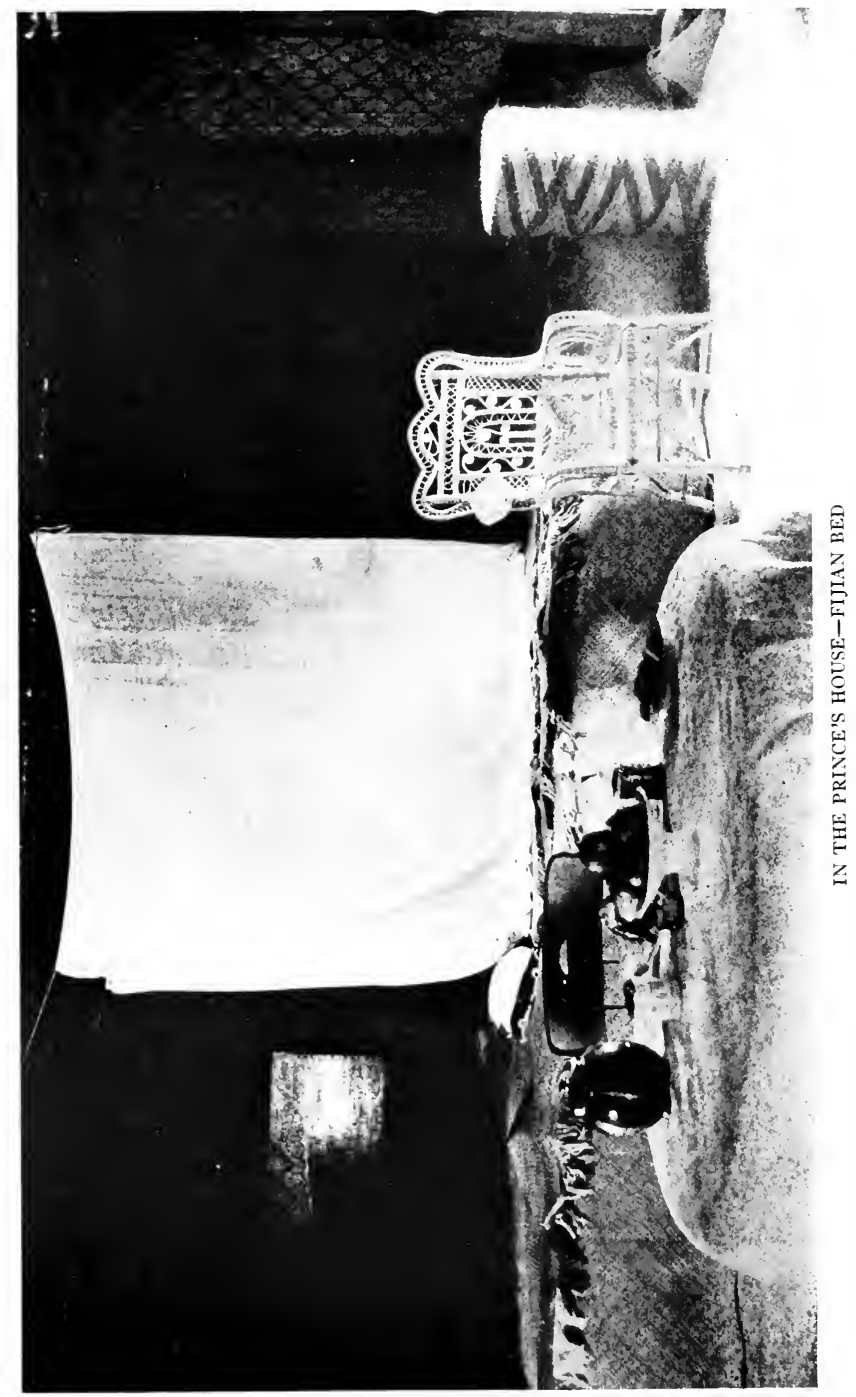


had been aiming for since I left Nanduri two days before. In another half-hour, I was enjoying a real meal at a real table, in the smallest and cosiest of the three "white" houses that, together with a sawmill and its buildings, formed the settlement of Tumba.

Here, as everywhere else in Fiji, I met with the kindest and most ungrudging hospitality. The white settlers of the Fijis are surely the most hospitable people in the world. A dirty, untidy hungry stranger suddenly appearing from the wilderness is welcomed as a longinvited guest, given the best of everything, almost fought over by several eager hosts, and pressed to stay as long as possible. His entertainers apologise for not being able to feed him on every civilised dainty known to Suva or Levuka, and hope he can put up with a room that is furnished less luxuriously than the guest-chambers of a big hotel. They neglect their business to "show him round," press gifts of curios, plants, shells, etc., upon him when he is leaving, and send him away with a hearty God-speed and a hope that he will come back again soon.

And the return for all this? Read most of the books of travel that have been written on the Fijis, or other islands. Note the sneers at rough accommodation and primitive living; the unkindly fun poked at people who have, perhaps, dropped a few of the customs of great capitals; the "paying off scores" against generous hosts who have managed in some way to incur the wrath of consideration-loving guests-and wonder then, as I wondered, that island hospitality should still be what it is. A Fijian who eats and rests under the roof of another regards such hospitality as a sacred claim, to be liberally repaid in kind if opportunity should arise. A white man takes all he can get, and laughs at his entertainers; would not dream of "knowing them at home," if he should 
ever meet them there; and regards the sacredness of the eaten bread as a fancy only fit for savages. Truly, we do not seem to send our best a-voyaging in strange countries.

The timber industry was what I had come up to he Ndreketi to see, and exceedingly interesting I found it. There are no woods in the world more beautiful and valuable than the woods of Fiji, athough want of capital, and, to some extent, want of enterprise, has prevented their becoming widely known. "Bua-bua," the boxwood of the Pacific, is vey common, and grows to an immense size. It weighs 80 pounds to the cubic foot, is very hard, and most durable. The "cevua," or bastard sandalwood-a strong-scented, very durable woodgrows freely, in logs one foot and two feet in diameter; and the real sandalwood is also found, though not plentifully. Another useful wood is "vesi," which grows two and three feet in diameter. It is much like teak, hard, heavy, and extremely lasting in the ground or out of doors; it is also rich-coloured and very easily polished. The "dakua" is one of the most valuable woods; it much resembles the New Zealand kauri pine, and grows to a large size, sometimes six and seven feet in diameter. It contains a great deal of gum, and quantities of this can be taken out of the ground wherever a tree has been. The timber is useful for almost any purpose. The "yaka" might be called the rosewood of the Pacific, if it did not also, in some degree, resemble mahogany. It is a wood of the greatest beauty, being exquisitely marked and veined, and taking a high polish. This is a wood that certainly should be known to cabinet-makers, and no doubt will be later on. The "savairabunidamu," a curious dark-red wood, is extraordinarily tough, and can be steamed and bent to almost any shape-a valuable 
quality. The "bau vundi" is a kind of cedar, very workable, and most lasting. A singularly beautiful timber is the "bau ndina," which is deep rose-red in colour, tough and firm, and suitable for engravers' use. Besides these, there are more than sixty varieties of other woods, all useful or beautiful, and most to be found in great profusion. The quantities available are very large; a great proportion of Vanua Levu and Viti Levu, and nearly the whole of many outlying islands, is covered with dense forest, untouched so far, except in two places-the small island of Ngeo, and the lower Ndreketi River, where sawmills have been established. It was the latter place that I visited. The upper reaches of the Ndreketi are untouched, and there is valuable timber along the course of almost every Fijian river, within easy reach of rafts and steamers.

At Tumba Mills, most of the timber is obtained from the forest eight miles farther up the river. I journeyed up the Ndreketi in a boat one day, to see the timber cutting, being conyeyed by four natives from the mill, and attended by Gideon, who acted the distinguished stranger, lounging on the seats, and entertaining the rowers with long tales and many boastings. By this time I had learned a good deal more Fijian than Gideon supposed me to possess, and I could understand something of what he said. One long serial story that occupied nearly an hour, and was listened to with the deepest attention and interest, excited my curiosity, after a while, and I tried to make it out. . . . It was neither more nor less than an exact inventory of everything we had had to eat since we left Lambasa!

"On Monday," it ran, "we had lots of yam, and rice with sugar, and tea, and four biscuits each, at the magistrate's, before we started. And on the way, there 
were some oranges; and Rubeni got a lot of cooked chestnuts from some people we met. Then, by-and-by, the marama had lemons and water at a stream, and I got the sugar she left in the cup, to eat. There was a good town presently, where the Turanga ni Koro had killed a pig, and we ate most of it, but the marama had tinned meat, because she said the pig was sick when it was killed. What did that matter? At Tambia, where we slept, we got two plates of crayfish, and yam, and a cup of tea the marama didn't finish. We stayed three days at Nanduri, and that was good, for the first day we had two boiled fowls among us, and yam, and ndalo, when we came in; and next morning there was broken biscuit the marama left, and the end of a tin of jam, before breakfast; and for breakfast . . ."

So it went on, day after day, disposing of Vanua Levu first, and then going back into the history of the journey through Viti Levu, six weeks before-a marvellous feat of memory, and a most curious enlightenment on certain points of native character. I enjoyed the odd exhibition very much, until a sudden recollection sprang up among the tangled oddments of three years' travel, and brought to my mind a conversation $I$ had heard between two highly educated and greatly travelled white men, on the smartest of the Cunard liners:

"Milan? yes, they do you very well there, if you know where to go, but if you don't-However, the Hotel-makes up for everything. We got real English food there, the genuine article, beefsteaks not scorched or stewed, good bacon and eggs, excellent joints and puddings-what does one want more? We stopped over at Marseilles. 'Try the bouillabaisse there-do, old man! Over estimated? Not a bit. Couldn't be! Last time I went by the Mediterranean route, we found time 
to run up to Venice, but you won't catch me there again. Look what they charge you for soda-water! and at the $\mathrm{Z}$-Hotel, where there is food fit to eat, the drains are murderous; while the $\mathrm{Y}$ - gives you oil in everything, and makes soup out of the roasts. No more Venice for me!'

Was there much to choose, after all, between the Fijian and the Briton?

The forest, or "bush," when we reached it, was delightfully dim and cool, after the glare of the river. A rough "skid road," crossed over with logs, had been cut through it down to a cliff above the river, over which the timber was slid into the water. Teams of ten to sixteen bullocks hauled each log from its home in the forest to the river highway, and once in the water, the timber was floated or rafted, according to its weight, down to Tumba Mill.

The "bush" here has very few flowers. There is little light under the overarching roof of lofty boughs, where the sun comes only as a thin trickle of stray beams, sifted through the canopy of close-set green. Orchids are found at times; and I heard rumours of strange, rare blossoms, unknown to botanists, appearing here, and in Taviuni, a great island not far from Vanua Levu. (It may interest men of science to know that in September, I904, some white settlers in the latter island found a single specimen of a flower never seen there beforea huge single blossom, shaped like a vase, and larger across the top than an ordinary soup-plate. It grew close to the ground, had apparently no leaves, and was very much ruffled and fluted at the edge. The colour was a grayish-lilac, with a large, dark-brown, cone-shaped pistil in the centre.)

“. . . Oh, the wonders of a tropical forest! the tough lianas that barred our way at every step, and 
had to be slowly and painfully hacked through-the brilliant honey-birds hanging like living gems on the rich blossoms - the marvellous chameleons, three feet long, that crept sullenly away at our steps, changing colours as they went! We could hear the fierce, wild boars and dangerous wild cats crashing their way among the thickets not far off; myriads of beautiful birds darted through the air; serpents and centipedes crept at our feet, and formidable ticks let themselves down from overhanging boughs, and buried their jaws, through all our clothes, in our flesh.

The above, I know very well, is what the reader expects, when hearing about tropical forests; so I have done my best to write the kind of thing that is popular. It will out, however. I didn't see all those thingsthough they were undoubtedly there, and I suppose, therefore, I ought to have seen them. Stanley would have seen them; so would Burton or Livingstone, or any decent traveller. The wild boars and cats would have come up to call on him at once, instead of keeping ten miles away: the snakes (harmless all) and chameleons would have come out of their holes, and off their high branches, and sat in his lap, or he'd have known the reason why. Even the ticks would have shown their ugly faces, and submitted to be photographed, like criminals in jail. But as for me, all I saw was a flight of parrots, gorgeous green and blue, with red necks, squawking away across a clearing, and a nest of wood centipedes-hideous, ill-smelling creatures, the size and shape of large sausages -on which I nearly trod. It would not have mattered if I had, as they were not the active, biting kind but the sluggish sort that is only dangerous to a bare foot or hand, which they burn as if with carbolic acid wherever the skin touches. These loathsome creatures must live in 
the shade; the sun is fatal to them. If a wood centipede stays out too late at night, and is caught by the morning sun while crossing some unshaded bush track on his way home, he dies at once, and leaves his corpse rotting in the cruel rays, as a warning to all won't-go-home-till-morning bush people.

Venomous centipedes are met with in Fiji, but they are not very common, and their bite is more painful than dangerous. I have found them under my bed, and about the bathroom, in Suva houses-ugly beasts seven or eight inches long, black, with red legs and feelers, horribly active, and very ready to bite if touched-but I never saw them in the bush. The only scorpion I saw in Fiji came out of one of my own trunks; it was about three inches long, and I shook it out of a nightdress just as I was going to put that garment on. I saw one tick, hanging on my horse's neck, as I rode back to Lambasa from the Ndreketi. The wonderful stick insects of Fiji, familiar in all home museums, are found on nearly every cocoanuttree. They are very ill-smelling, and squirt a fetid fluid at one's eyes, if handled. Leaf insects I never saw, except when the natives caught and brought them to me; but all the guava-bushes have them, although a white man's eye can seldom distinguish them from their shelter. They are most miraculous and uncanny creatures, absolutely leaves endowed with the power of motion, so far as the most scrutinising eye can see-for even their legs and heads are a precise copy of stalks and small leaflets. Honey-birds-dainty little black-and-white creatures that hang on the scarlet hibiscus blossoms, and dip their beaks into the honey-vessel of the flower-I only saw about the suburbs of Suva; and wild boars, cats, fowls, goats, or cattle I never got a glimpse of anywhere. This is not what is expected of a traveller, I know, and I humbly 
apologise for my deficiencies, offering only the excuse that, like George Washington, I cannot tell a lie, even when I ought.

A white man cannot, as a rule, find his way about the Fijian bush, but a native is never at a loss, even if he is new to that part of the country. He will slash his way through, with the heavy knife he uses so cleverly, at an easy two miles an hour, and he will never be at a loss for food and drink, even though the cocoanut palm is absent from the forests of the interior. If there are no streams, there is a thick ropy liana which oozes good water when cut; and eatables are never wanting. Almost everywhere, the flat, arrowy leaves of a certain trailing vine advertise the presence of plump yams underground; wild potatoes are also found, and several other excellent roots-among the best being the sugary root of a tall thin shrub, conspicuous enough for even a white man to see at once. There are also plenty of chestnuts, and one or two kinds of berry. It is small wonder that, in a country such as this, the native should be accused of indolence and want of enterprise. If the roadsides and commons of England grew roasts of beef and loaves of bread (yams, potatoes and chestnuts being fair equivalents of these, for a Fijian), we might find less industry anong our own working classes. And certainly, if every man owned or shared enough acres of land to make him independent of outside employment (as is the case with nearly all Pacific islanders), most people would think as little about the "sacred dignity of labour"-for some one else, at some one else's starvation prices-as does the provoking Fijian of to-day, who will not go and improve his mind by toiling twelve hours a day in a big company's plantation, for money that he doesn't particularly want. 
<smiles>C1CCCCC1</smiles> 


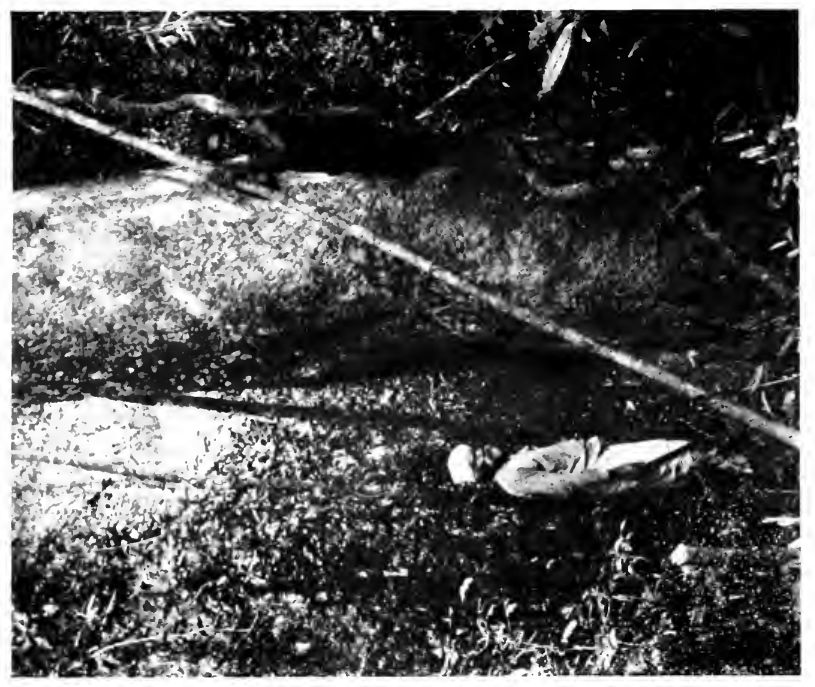

-1
$=$
$=$
2

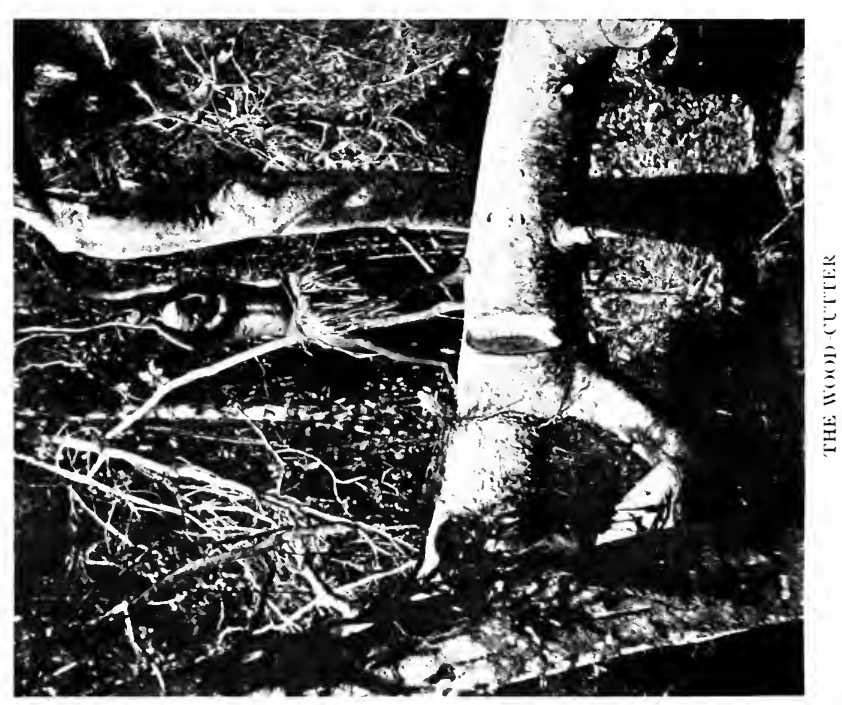


Land cleared from bush, about the Ndreketi, is said to be extremely suitable for cocoa planting. There is also a good deal of naturally cleared land available.

Returning from up-river, I spent a pleasant day or two "loafing" about Tumba, watching the little steamer from Suva coming up to ship timber, and seeing the big dakua logs run through the mill. The steamer is about I 80 tons, and could go at least eight miles further up than she has any occasion to do at present, since the river, though not very wide, is extremely deep. 


\section{CHAPTER VII}

\section{INDUSTRIAL SURPRISES}

At the Back of Beyond-The Last of the Cannibals-A Pleasant Old Devil-The Plague of Fleas-When Gideon went Wild-Nanduri once more-The Vanilla Planters-Cattle-ranching in Fiji

THE Ndreketi, or, more correctly, the Senganga 1 district, is truly the "back of beyond." Here, in the dense forests, and the lonely, little-known bush villages, traces of heathenism still lurk concealed, in spite of the fact that all the natives of the district are nominally Christian, and attend Sunday church, conducted by a native teacher, with praiseworthy perseverance. The "luveni wai" worship, though persistently combated by the Government, has never yet been fairly uprooted. This, so far as I could ascertain, is a strange mixture of heathen "miracle play," devil-worship, and murder. The natives taking part in it work themselves up to an extraordinary pitch of frenzy, during which one of them becomes filled with the spirit of a god, and declares himself to be invulnerable and immortal. During my stay in Fiji, a case of attempted murder was tried in Suva, which rose directly out of the "luveni wai," as practised in the Senganga district. One man threw a spear at another, to prove that the latter was really a god come down from heaven, and therefore immortal. The "god," however, came off second best, being badly wounded, and crippled for life, by the spear. The other was sentenced 
to several years' imprisonment, as, apart from such accidents, it is illegal to perform the "luveni wai" at all.

"Tembe-tembe" worship, which is devil-worship pure and simple, is known to exist, although carefully concealed, about the Ndreketi. There were one or two men about Tumba who enjoyed the reputation of being devil-priests on the sly. One interesting character, who was always hanging about the house, was known as Tha Levu (Bad Lot). He is a hereditary devil-priest, and is sometimes suspected of following his ancestors' footsteps, though this may be mere slander.

$\mathrm{He}$ is a very clever and civilised personage, with an excellent English education, acquired during a term of eight years' penal servitude in Suva, which he has not long completed. In I 894 , there was a cannibal outbreak within a couple of miles of the place I visited. A chief who had been oppressing the people was murdered and eaten, with all the ancient religious rites, by Tha Levu and two other men. The others were supposed to have influenced Tha Levu, who was only a young man at the time, so he was let off with eight years' imprisonment, while his companions were hanged. He has now been back in his native village for a year or two, and is a person of considerable importance, much admired by his neighbours. On one occasion, while I was passing through the village, it came on to rain, and Tha Levu politely asked me to shelter in his house. I went in, and was entertained with courteous English conversation, and photographs of Government House dignitaries. Subsequently, Gideon, who was a perfect sieve of gossip and chatter, informed me with sly giggles that Tha Levu was "plenty good man, plenty big man!" and that he had told my men all about the cannibal feast; said it was first-class fun (as far as I could understand), and that he 

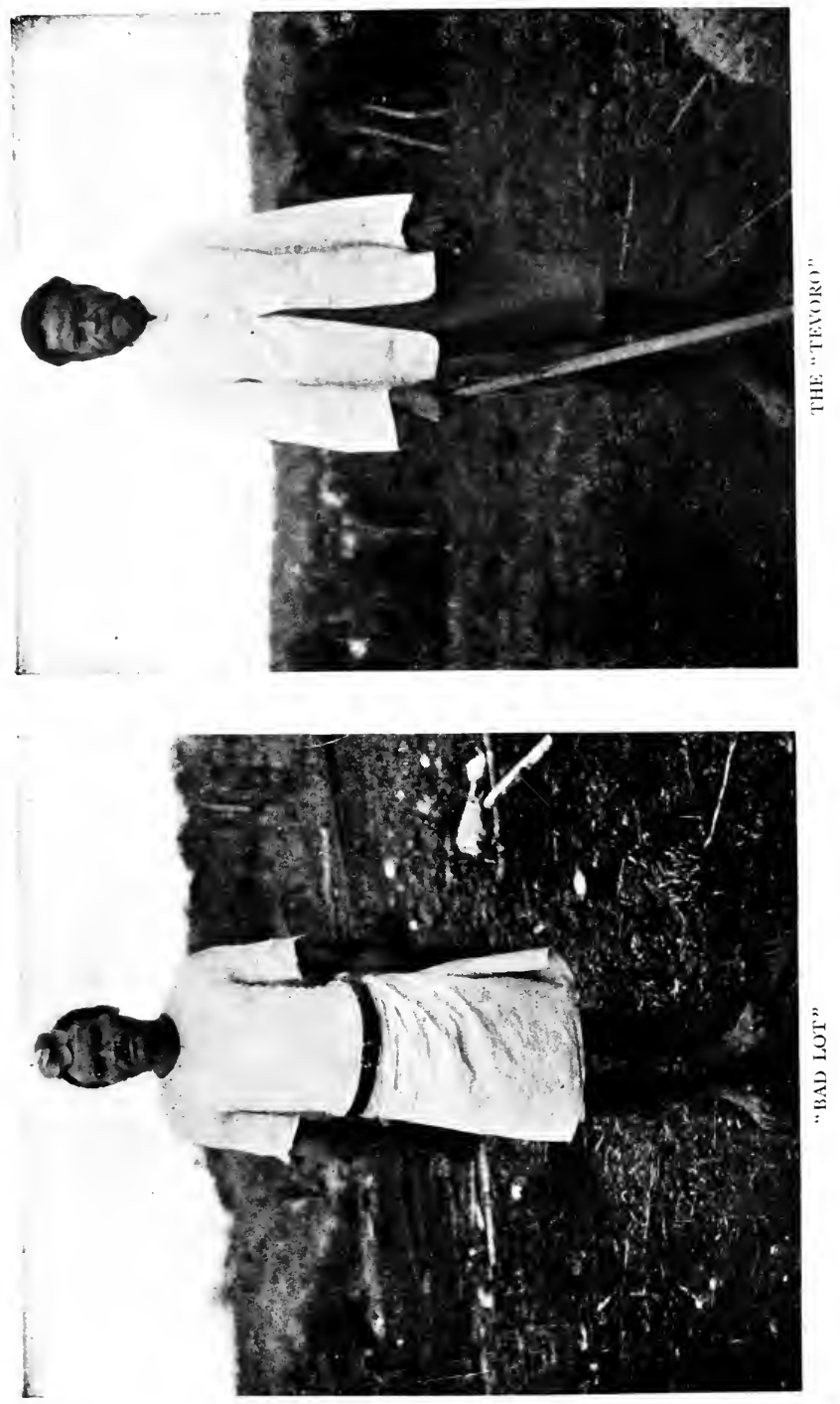


$$
\text { 을 }
$$


only wished he had a chance of doing it all again! It was perfectly obvious that Gideon and the others admired him inmensely, and considered him the biggest hero they had ever met. I told Tha Levu that I thought his name fitted him to a hair, and that I would like to take his photograph to send home to England as the biggest villain in Fiji. Mr. "Bad Lot" grinned delightedly, and at once dressed up his head with a huge yellow allamanda flower, to do the occasion justice. I photographed him as he stood, and hope the English-speaking public will admire him half as much as he obviously admired himself.

I much preferred a pleasant elderly gentleman from across the river, who came up to call one day, dressed in a nice white shirt and a heliotrope velveteen sulu, and told us conversationally that he was a "tevoro," or devil. He seemed rather a superior sort of devil, on the whole; if he had horns, they were hidden in his stiff, upright hair, and his tail was certainly not visible. Being a devil, he told us, he had power over certain other devils, among them, the demons who governed fleas, centipedes, beetles and other objectionable creatures. He had heard that my host was looking for him (which was true), to ask his advice about the plague of fleas that made the house almost uninhabitable; so he had come across the river, and would be glad to do anything in his power, because the white man had often employed his wife to do washing, and had paid her well.

What could he do? we asked.

Well, said the kindly devil, he could drive away all the fleas for us, for they were bound to obey him as their master; and he would do it at once, if we liked. But we must first assure him that we believed in this power. If we disbelieved, it would paralyse him, and he could not work. No one else had the power but himself. Any 
man could do the simple things he was going to do; but, except in his hands, they would have no effect; and even he could not make them effective, if he was not helped by our belief.

We all assured him that we did believe in his powertruthfully enough, for we had heard of his performances before this, and knew that, however he had done it, he had driven away the fleas most successfully and permanently from the house of the junior partner a year earlier.

The "tevoro," thus reassured, called up Gideon, and told him to help him in moving all the furniture clear of the walls. Gideon, gray with fright, and shaking all over, obeyed him, and then bolted straight out of the house to hide himself in the cowshed. The "tevoro" went into the yard, picked up a common piece of bamboo, and lit the end of it. He then returned to the house, and walked three times round every room, close to the wall, keeping his body bent double, and holding the burning end of the bamboo about a foot from the line where the reed-work walls joined the earthen floor. All the time, he muttered softly to himself in Fijian. My host, though a good Fijian scholar, could not understand what he said.

Every time he passed one of the two doors, he went out into the yard, and snuffed the end of the bamboo on the ground, afterward making a neat little dirt-pie of the snuffings, and leaving it on the earth. The whole ceremony did not take more than a quarter of an hour. At the end, he stood up, and told us:

That the fleas would all go away.

That they would not all go at once; some would go that night, and the rest to-morrow. (A rather notable point, I thought.)

That they would not come back. 
That we might never trust him again, if all this was not true.

Then he accepted a present of a shilling and some tobacco, and went smiling away. I never saw the amiable "tevoro" again; but he was certainly a nice old devil.

All that he had promised came true. That night, the fleas were much less annoying than before, and the baby, which had been enjoying very broken rest, slept better. Next night there was not a flea in the place, and the poor baby's little bald head, which had always been spotted as if with measles every morning, was white and smooth again. If we grown-ups had been "suggested" into thinking there were no fleas about, the baby, at all events, could not have been influenced, nor could we have been mistaken in the marks.

There was nothing in the bamboo to drive away the fleas, for it was picked up in the yard, just as it lay; nor are these active creatures so easily alarmed as to be driven away by the sight of a little flame. Furthermore, if by any sleight-of-hand some native drug had been used, it would have taken effect at once, and not driven the invading armies out in sections as the "devil's" proceedings certainly did. I leave the problem to other heads to solve, confessing that I find it insoluble myself.

It was time now to be making my way back again to Lambasa, for the Suva steamer would soon be due there. But an unexpected obstacle arose. Tha Levu's society, and (I suspected) the influence of certain midnight gatherings in the forest, where the Wesleyan religion was considerably at a discount, had gone completely to Gideon's head, and he was getting beyond control. A more curious jump-back toward the primitive type I had never seen. My civilised, obliging, English-speaking 
courier, with the bright, intelligent face and sunny smile, had utterly disappeared, and in his place I had a slouching young savage, sullen, disrespectful, and careless, with a flattened, stupid face, unlit by any spark of good-humour. He took no care of my belongings, transmitted my orders incorrectly to the men, and disappeared for hours at the time when he was most wanted. This could not go on. I did not wish to go back to Lambasa without an interpreter, as I knew too little Fijian to get along comfortably; but I made up my mind to give Gideon a lesson. The white men of the settlement became interested in my dilemma, and offered to "talk to him" for me; but I knew that any such delegation of authority would only make matters worse. So I waited until he slouched up to the cook-house one morning, insolently late for something I wanted him to do, and began my sermon.

It does not much matter what I said. It was picturesque, and there was a great deal of it, dealing mostly with the lofty eminence of my own position in life, the many great deeds which I had (not) performed, and the horrible things I did to people who offended me. I ran rapidly over the weak points in his own career, vilified his ancestry, and suggested that it would be gross flattery to describe him as food for cannibals himself. I told him that he was to leave my service that instant, and pictured briefly but vividly the crawling ignominy of his solitary return to Lambasa. By this time, my big Fijian was crying loudly into the chopped cocoanut prepared for curry, and knuckling his wet eyes with his huge black fingers. I told him that I did not care if he cried himself dead; that he did not belong to me any more, and, in fine, that he was to go at once, and never let me see him again.

"Where I going, Missi N'grimshaw?" sobbed the 
forlorn creature. I made the obvious reply. It convinced him that I was in earnest, and, rejecting the small pile of gold coins, representing his wages up to date, that I tried to hand him, he trailed out of the house, and collapsed in a miserable heap near the veranda. All day long he sat there, asking me, whenever I passed: "Missi N'grimshaw! 'S all right?" and receiving the same invariable answer: "No! go away." His anguish of mind rose to full height when, later on, I went down to the river, and on board the timber-carrying steamer for afternoon tea. It seemed to him that I was going away at once to regions unknown, and he hovered about the bank, his face lined and drawn with despair. This tour had been the glory of his life, and he could not face the disgrace of being cast down before all Vanua Levu, after all his boasting and peacocking. A Fijian's grief is like a child's-absolute and intense for the moment, and rejecting all thought of consolation-and, moreover, his vanity is the very weakest spot in his armour. Small wonder, then, that the culprit's wretched, anxious, tear-swollen face almost softened my unkindly heart. But I did not call hin up till night, and then I only asked him; "Are you going to be good?" "Yes, sir!" he said eagerly. "Then you may tell me that you are sorry," I said. He looked down, and his face grew sullen again, for a Fijian hates above everything on earth to say that he repents-such an admission is intermingled with various old customs that give it a significance unknown to whites. I turned away to the house. Gideon, seeing his last chance going, called out; "Missi N'grimshaw!" "Well?" I asked, half turned away. Very slowly came the reluctant words: "I so-ry."

"All right, Gideon," I said. "You can go round and get your supper, and have the horse readyat seven to-morrow." 
It was all right. He ran like a mongoose to the cookhouse, his face split up with smiles; and thenceforward, till the end of the trip, I had no trouble with Gideon. A day or two later, at Nanduri, he came to me and told me that he had been "levu lia-lia" (very mad) at Tumba, and that he was "tha" (bad). I agreed with him cordially, and asked him why he had acted in such a manner. The question seemed to have a certain academic interest for him; he debated it seriously, and then said that he thought the bad people in the woods had made him bad, too!

That is all of Gideon. I dismissed him finally in Suva, with his wages and a decent testimonial, and saw him go off to buy a heavy blue serge coat, in which to torture and delight himself of a Sunday; a sulu of black French cashmere, at eleven shillings a yard; quantities of tobacco, sweet-stuff, fresh bread, sugar and other civilised luxuries dear to the native heart. Wherever he is he is a great man by reason of these possessions, and his important journey, and is, no doubt, happy and content.

My kindly hosts warned me, when I left Tumba, that it would be well for me to wear my revolver round my waist, when travelling back, instead of having it conveyed in the baggage. (No-I know Stanley wouldn't have done that; but then, he did not care how his jackets sat, and didn't object, either, to looking like a cowboy on a spree.) They said that my Ndreketi carriers were a rough lot; that Gideon might break out again; and that, in any case, the prevailing customs of the devil-worshippers had given a bad tone to society up the river. So I carried the weapon in my belt, and felt indescribably foolish, but perhaps a little more peaceful at heart than I should otherwise have been-for, after the week up the river, I 
could not feel quite certain that one of these impulsive children of Nature might not be moved suddenly to heave a rock at the back of my head, should the fancy take hin as we plodded along.

The bad place where Somo-somo had got into trouble was temporarily bridged by the villagers for me, and I got safely to Nanduri in a couple of days, without any adventure worse than ten hours of drenching rain. My men were bitterly disappointed when I pressed on to Lambasa, after a single night's stop at the Brighton of Vanua Levu; but I wanted to see the vanilla plantation at Lambasa before the steamer left, so was deaf to their cunning hints about Nanduri, and melancholy sighs.

Lambasa, a day or two later, that I found Gideon secreting certain torn scraps of paper, and a broken ink-bottle, that I had thrown away. He was much embarrassed when I asked him what he wanted with such rubbish, and only murmured shamefacedly that he "plentee learning write, school, Suva.

. . I shut my eyes, skipped a racial and moral gap of some thousands of years, and felt firm ground underfoot. In certain things, the black and the white (like "the Colonel's lady and Judy O'Grady") are "as like as a row of pins."

"You can have some of my paper and envelopes to write to your friends, Gideon," I said in a lordly manner. "It's a penny to Nanduri by the Government post. Here-you can have a stamp. One envelope?"

"Thankyouverymuchdeedsir," replied my courier, all in one word, and getting up to salute, military fashion. "Seven umvelose (envelopes), seven samps, I liking thankyousir!" 
No wonder Nanduri was popular!

I was very much interested in seeing the vanilla plantation, for this is one of those new departures that have irritated the oldest inhabitant almost to frenzy. Somebody in Viti Levu once failed with a vanilla plantation. That was enough for the oldest inhabitant. $\mathrm{He}$ solemnly cursed vanilla, throughout the rolling ages, evermore; and to any tentative inquirer his sole answer was and is: "Don't be a dam fool. It's been tried!"

Nevertheless, a certain enterprising man and his wife, who were getting rich very slowly indeed keeping a country store, resolved to brave the displeasure of the oldest inhabitant and his numerous relatives, and try whether the magic bean might not do for them what it had done for others, in South America and the West Indies. So, in the face of some actual opposition, and continual ridicule, they expended their little capital of $£ 25^{\circ}$ on the leasing of eight acres of warm, sheltered valley land, and the planting of 9,000 cuttings of good Mexican vanilla. For three years, with the assistance of one Fijian, and occasionally a couple of Indians, the industrious couple kept their plants weeded and tended, and, latterly, looked to the fertilising of the flowersa rather tedious business, done every day by hand, in the earliest hours of the morning. And at the end of the three years the reward came, for the plants were yielding splendidly, and were expected to give about 9,000 pounds of dried bean, bringing an average price of ros. a pound. The fruits of the first season were just coming in when I visited the plantation, and the lucky young couple were counting up their gains, present and future, with joyful hearts. Some of the old settlers, both of Suva and of Vanua Levu, were exceedingly grieved-not, of course, because the plucky pair were making money, but because 
they were sure that there was something wrong somewhere, and it couldn't possibly be themselves, so it must be the vanilla-or the planters-or something, anyhow! Had they not been saying, all these three years, that the chemical substitutes for vanilla had ruined the price; that the cost of labour ate up all profits; that the climate wasn't right, and the market bad?-and there were these people actually doing all the important work themselves; the husband getting up at break of day to oversee the weeding and to fertilise the flowers, with a little occasional help; the wife attending to the scalding, and the sweating in the sun, of the gathered harvest-the beans turning out splendid in quality, and fetching up to 24 s. a pound, with a safe average of Ios. - and the whole enterprise simply "humming!" It was disgusting-so they felt.

Mr. C. kindly gave me all the particulars I wanted, and furthermore, showed me over his pretty little plantation and modest drying-yard. The beautiful, thickleaved vines were trained over young castor-oil shrubs, in one or two shaded valleys, where the sun was not too fierce, and hurricanes could not damage the crop. The work did not seem very hard; indeed the planter has not yet given up store-keeping, in addition. According to Mr. C., there is no reason (except the oldest inhabitant) why vanilla should not do well in Fiji.

"But remember this," he added, "it's the poor man's friend-not a gold-mine for companies. Hired labour, of the kind one gets in Fiji, won't do. You must work yourself. Care, care, care-that's what vanilla needs; care and common sense. A man with a family has a great advantage; he can set his boys and girls to work."

"Girls? In this climate?"

"Certainly! Vanilla's often cultivated by ladies alone, with a little help for the weeding, in the West Indies. The 
fertilising of the flowers is exactly the work for a woman's fingers-just a pinch, and a touch with a match-and it's done in the cool of the morning. The curing of the beans couldn't hurt a baby, if it had brains enough to do it. There's no great mystery in that, either; a good handbook, or a few talks with a practical planter, should set anyone in the right way. Yes, my wife and I are satisfied with the results of our venture-we may well be. Of course, it could be done on a smaller scale, and still pay very nicely indeed."

Cattle-ranching on a large scale is not exactly the kind of thing one expects to find in a South Sea island, but Fiji is full of surprises. It was only one surprise more, therefore, when I received an invitation to visit a large cattle ranch on Taviuni, belonging to one of the oldest and most respected settler families of Fiji. The $\mathrm{T}-\mathrm{S}$ have been in Taviuni for thirty years, and fortune has favoured them greatly. If one needed a refutation of the common idea that no one can grow rich in "The Islands," this Taviuni family furnishes a ready instance to the contrary.

Taviuni is one of the larger islands of the group, being 2 I 7 square miles in extent. It is supposed to contain the most fertile land in Fiji, and to have the most beautiful scenery. The latter claim is hardly just, though the island is very lovely. Anyone who has travelled much about the group will certainly uphold the claims of the Tholo West country (Singatoka and highlands) against all other.

One gets to Taviuni in a little inter-insular steamer, which may take a day, or the best part of a week, on the journey, according to the number of islands that have to be called at. On most of the islands one finds a "reigning 
$\because$.

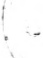




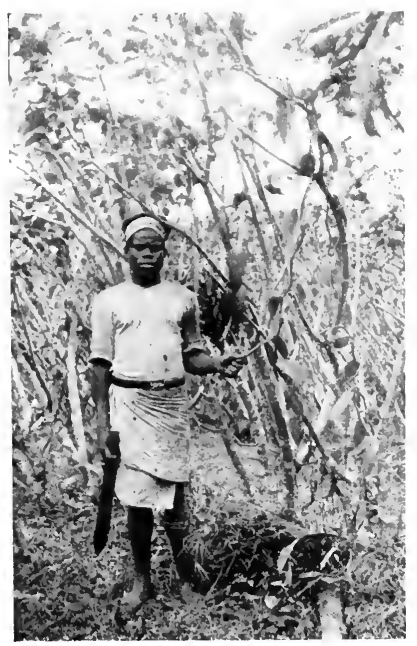

VANILLA

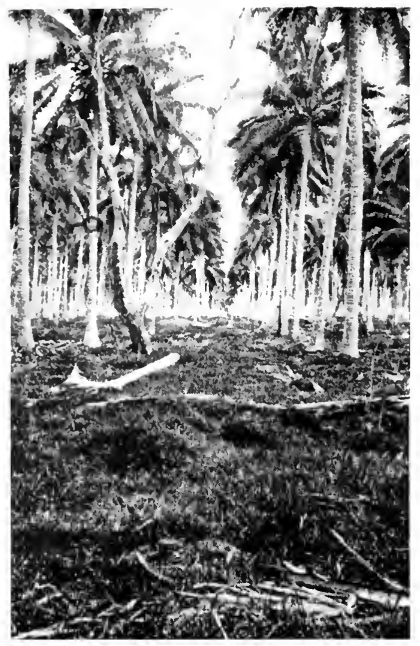

UN A COCOANUT PLANIATIUN

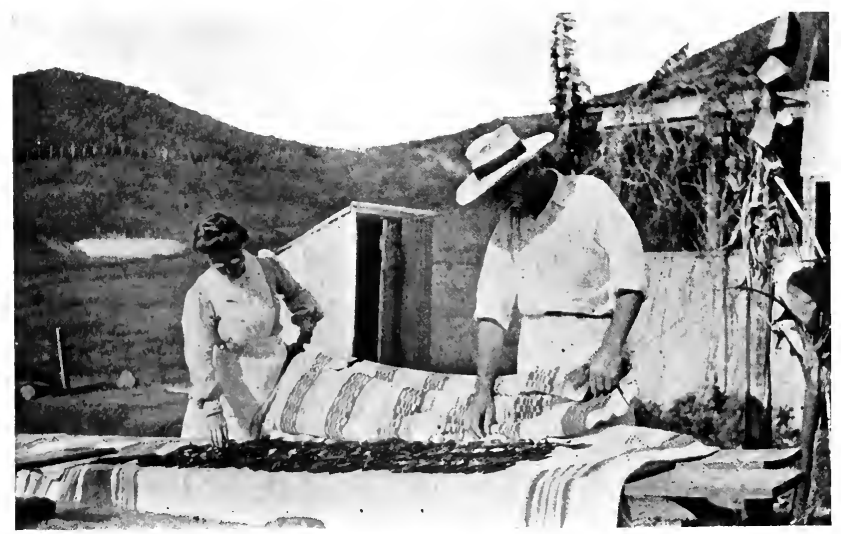

DRIING VANILLA 
family" of white settlers, who own the place, and make their living by planting on a large or a small scale. Copra is the invariable crop. The labour is nearly all imported Indian, since very little agricultural work can be had from Fijians.

If the steamer stops long enough, an invitation is generally sent to any passengers there may be, asking them to come ashore and lunch or dine. The outer islands are lonely places, and white society is always at a premium. Most of the settlers' houses and surroundings, in spite of the isolation, are wonderfully well kept up, and there is a standard of education and refinement among the planters themselves that is astonishing to anyone who has travelled in the larger British colonies, and seen to what unfortunate depths the isolated settler and his family too often descend. Indeed, it is a matter worthy of very special note, that all over Fiji the white settlers, old and new, might for the most part pass as towndwellers taking holiday in the country, so far as general good manners and education are concerned. Exceptions to this rule are nearly always due to native or half-caste marriages, and these are not at all common. As for Suva, it is quite the finest and most up-to-date city in the whole Pacific (with the possible exception of Honolulu), and there are many important Australian and New Zealand towns that fall far behind it. Assuredly, Fiji is no backwater in any sense of the word.

The great success of the $\mathrm{T}-\mathrm{s}$ of Taviuni has been attained by a combination which they were the first in the islands to try-cattle and copra, worked together. The palms on the estate number about sixty thousand, planted for the most part in regular rows forming arcades of extreme beauty. Several thousand head of cattle are generally run on the place, the number varying a 
good deal from time to time. Every boat carries away large numbers of beasts to Suva, which consumes the greater part of the meat produced by the estate.

The copra is produced by the usual simple process of the islands. The nuts are husked and opened, and the kernel cleared out, by the native labourers. In wet weather, the cut-up kernels are dried in artificially heated sheds, while during the dry season they are spread out on high platforms in the sun. This is all the preparation required, beyond bagging. Not a complicated process, certainly, for an industry that pays so well.

Cattle do very well in Taviuni, as in most other parts of the Fijis, and I have never seen better beasts than the mob of some thousands that I assisted to drive into the stock-yards on a certain memorable day of my stay. My hosts had kindly offered me a mount, and told me that they did not think the riding would be more formidable than cross-country work at home; so I accepted. . . and was more sorry than I should have cared to say, an hour or so after the start from the pretty homestead in the early morning. For I then discovered what a good many British riders have had to learn in the colonies, that taking a horse across any number of English fields and fences has nothing in the world to do with taking him (or letting him take you, as is more likely) over the broken ground of a rough and wooded tropical country, in company with a few thousand extremely excited cattle which have got to be driven all in one direction, to a place some miles away.

My mount was a stock-horse trained, and a very highspirited young thoroughbred to boot, who wouldn't be ridden except with a light snaffle, bucked when one held him in, and could do feats in the way of step-dancing at full gallop among boulders, gullies, tree-stumps, and 
sudden deep holes, that made one suspect him of relationship to a kangaroo. I never saw anything like it before, and I have almost ceased to believe, at this distance of time and space, that it ever happened. Horses do not, and cannot, tear full gallop over country that has not a level inch, that has as many holes as a honeycomb, and as many stumps as a hairbrush, that is cross-barred with gullies, and peppered with loose rocks. . . . I must certainly have dreamed it. Yet it didn't seem like a dream; you cannot dream that the skin is coming off the insides of your fingers, and the bend of your knee, and find, a week after, that the traces of the vision are still plain to be seen-you cannot, unless you have the imagination of an Edgar Allan Poe, figure to yourself what kind of a noise some thousands of cattle make bellowing all round you - and you certainly cannot, if you are an unlearned female, evolve out of your own consciousness the sort of thing that men say to cattle under these circumstances, when they think they are safely out of hearing of the visitor-but aren't.

No, the horse and his surroundings were real enough, though unusual. It would not do to take an expensive English hunter out to such a place, and trust him to follow an Australian stock-horse. Your hunter would be hounds' meat before he had gone a hundred yards, and as for his rider.

I did not get thrown that day, but no one saw the occasions on which I escaped by the skin of a pommel from blank disaster; no one saw how often my head was in the scrub, and my heart in my mouth. I never thought to get back alive. If the reader wants to know why, let him take a young spirited stock-horse out rounding-up cattle in an extremely broken and woody country, for the first time of asking-and he will have news to 
tell me, however much he may fancy his riding. It may be objected that I could not have driven half-wild cattle in a strange country. I certainly could not, but my mount could, would, and did. And if anyone wants to know how it felt, let him imagine himself riding an extremely active collie over fifteen hands high, driving a dozen rebellious flocks at once in and out of a tangle consisting of Stonehenge, Dartmoor, and the New Forest, all hashed up together-and he will have some idea.

I did drive cattle that day to some extent; at least, I looked as if I were doing so, though as a matter of fact, I was cursing the horse and saying my prayers by turns. None of the beasts attacked us; I should not have been sorry if they had, because then I could have stopped squabbling with the horse myself for a little. It was his mathematical accuracy of eye that was the worst of him. $\mathrm{He}$ had been ridden by a man hitherto, and he knew exactly how much space to allow for the half of a man, when twisting and turning through scrub like an impressionist dancer circling among her own draperies. But he did not know how much to allow for the whole of me, and every time he whisked round a tree on the near side I just saved myself by the fluff of my habit. . . . If I went cattle-driving every day for a week, I should be conspicuously pious at the end of it-or else conspicuously dead.

When we had ridden the cattle up to the stock-yards, and the men were driving them in, one of my hosts came up to me, and politely congratulated me on my riding. (If he had only known . . . but he was too well occupied during the ride to observe anything save the fact that I was still alive.)

"I'm glad you've had a good time," he said. "Round- 
ing-up is really great fun you know, and we always like our visitors to see it."

"But mostly," he added, as an afterthought"mostly, you know, they fall off!"

"There, but for the grace of God, goes John Bunyan," I murmured, as I slipped out of my saddle.

"I beg your pardon?" said my host.

"I was only saying that I hoped there would be sodabuns for tea," I explained untruthfully.

"It does make one hungry," he agreed.

Planter life in Fiji, in these days, seems to be approximating closely to what one has heard of planter life in the West Indies, in the prosperous times of the earlier Nineteenth Century. The comfortable houses, the consideration of "appearances" that really means the highest self-respect, the taste for literature and music, the generous hospitality and free-handed entertaining, the pretty, though simple dress of the women, the manly, open-air character of the men, the absence of stress or hurry-all these things tend to make the planter class of the Fijis representative of a dignified pleasant era that one almost fancied had passed away from British colonial life. Fiji is certainly not as other colonies. A colony, generally speaking, is purely English, like India, its people being, in consequence, impatient of their surroundings, and only eager to get home for good-or it is purely colonial, like Australia, with a new set of national characteristics, which may be better or worse than the characteristics of the home English, but are at all events quite different. Fiji, however, has steered a course of its own, and is Colonial and English at the same time. It is hard to understand why, for the settler in these islands, early or recent, seems always to have come with 
the idea of making the country his permanent home, and to have carried it out in most cases; furthermore, he is usually proud of his country, and ready to defend it against all comparisons. The fact, however, remainsFiji is more English than any other colony south of the Line. A Briton may be pardoned for thinking that it is none the worse. 


\section{CHAPTER VIII}

\section{AN ANGLO-FRENCH DILEMMA}

The Mysterious Islands-Where No One Goes-What Happened to the Cook-A Fairy Harbour-Extraordinary Vila-History of New Hebrides-What France intends

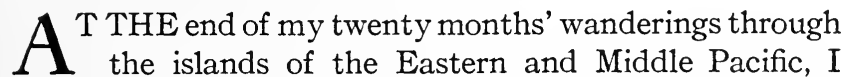
found myself in Sydney, where everyone was talking about the New Hebrides.

It was September, 1905. The Anglo-French Convention, so Australians hoped, would get to work on the New Hebridean question almost immediately, and settle all the thorny problems that had been perplexing and impoverishing the settlers. There had been fresh murders in the islands, and a punitive expedition was talked of. The "White Australia" cry, which had insisted on the passing of vexatious tariff laws against all New Hebridean produce, was now being answered by a bitter wail from white Australians up in the islands, who could not make butter for their bread under the new enactments. Altogether, the New Hebrides were providing much food for talk and guesswork.

It was an odd fact, under the circumstances, that no one really knew anything to speak of about the place. The New Hebrides are not very far from Australia-only about I, 500 miles northeast of Sydney - and they are by no means an insignificant group, since they extend over seven hundred miles of sea, and some of the islands are sixty 
and seventy miles long. Further, there is one monthly boat direct from Sydney, and another that goes round by New Caledonia. For all this, and for all the fact that Australia understands the group to be the weakest spot in her sea surroundings and defences, the great southern continent knows almost nothing as to values, prospects, and present conditions of the place. . . . True daughter of her little northern parent, this big Australia, inheriting the weaknesses as well as the virtues of her mighty mother. For when did the stay-at-home English accord to their far-off colonial interests more than a stepdame's grudging share of interest and help?

I wanted to know a great many things about these mysterious, murderous New Hebrides, where the interests of England, France and Australia seemed to be clashing in a manner altogether inexplicable, but none the less astonishing. Questions, however, only succeeded in reaping a remarkable crop of know-nothingness, don'tcareishness, and simple lie. Therewith was always politeness, for the Australian is nearly, if not quite, as courteous to women as the American-but only two Sydney people could tell me anything at all about the place, and their accounts were gloomy. I was not to suppose that the New Hebrides were like Fiji. There was no law, no government, and next to no regard for human life. The natives were murderers and cannibals to a man; I should be shot, if I went; if not shot, eaten; if not eaten, killed by fever. Yes, a few travellers had been, though it was not a tourist place by any means; but they had all kept to the steamer right through the trip, and only taken short walks ashore. If I persisted in going, I had better do the same. But I should do much better to stay in Sydney, and occupy the time taking trips about the harbour, which really was 


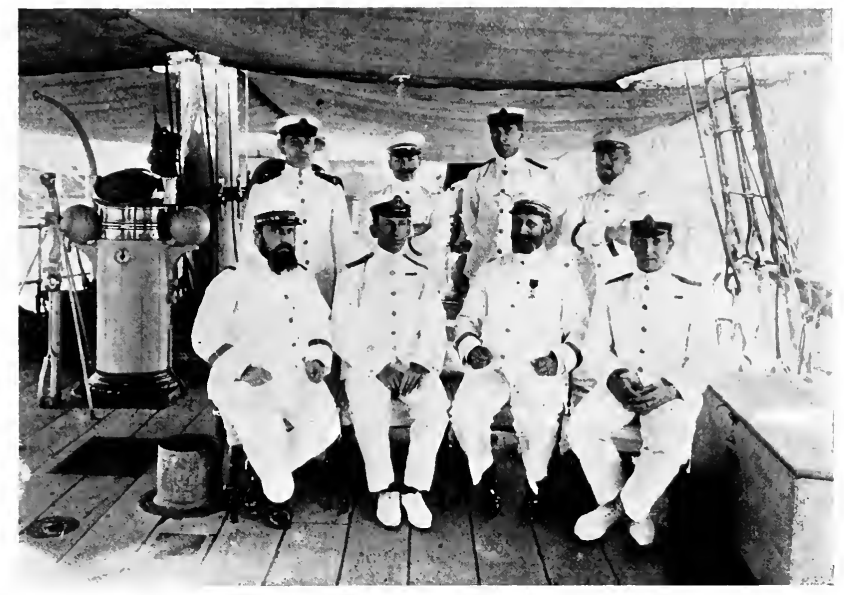

THE ANGLO-FRENCH NAYAL COMNISSION

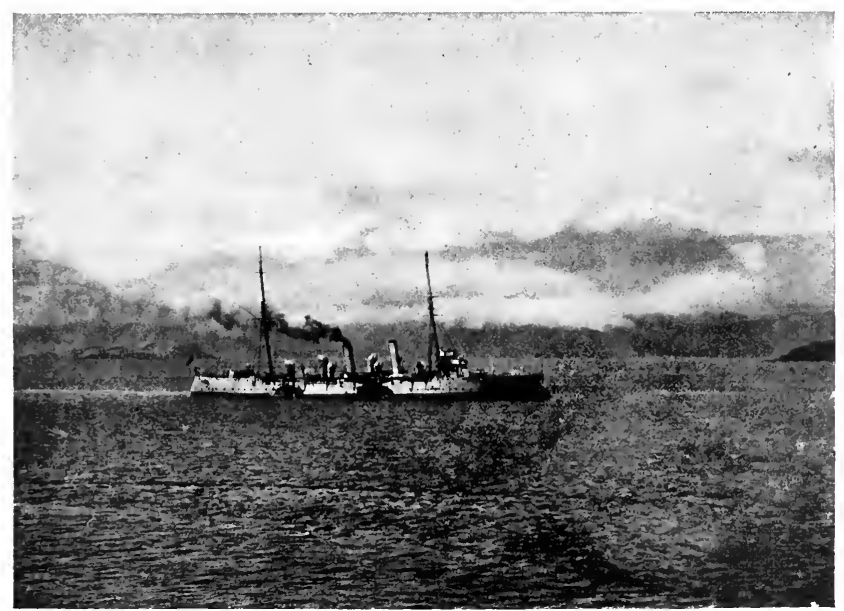

H. M. S. "PEGASUS" 


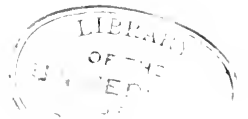


I had an engagement, and I could not stay to hear about that harbour. People who have been to Sydney will know why. But I had already heard quite enough to decide me to follow the traveller's excellent rule of contraries, and go to the New Hebrides forthwith. All the really "good times" I have had, in the course of many thousands of miles' wanderings about odd corners of the globe, have been obtained by the simple plan of avoiding the places which every person should make a point of seeing, and seeking those from which one is most carefully and earnestly warned away.

The truth is that in the places where "everyone" goes, almost no man sees with his own eyes. It is impossible to do so, unless you are a savage or a genius; and most of us are neither (though a select few, in the course of history, have even contrived to be both). The celebrated spot, whether it be Lake Como, or Niagara, or the Taj Mahal, Jerusalem at Easter, or Japan in cherryblossom time, is like a photograph upon which a countless number of others, all more or less similar, have been superimposed in the well-known "composite" style. One can only see the famous place through a dim haze of Brown's, Jones's, and Robinson's historic British feelings about it, outlined with touches of Smith the great traveller's writings. In the whole blurred, worn-out picture, each man's personal impression counts for just another touch of shade set upon a shadow that has long been there; just another high light lost in the edges of a high light that has been in that precise place for centuries. . . . It is impossible to admire by the battalion, and yet enjoy to the full that sense of an individuality enlarged by experiences absolutely new, that is the real heart of travel-pleasure. And this, perhaps, is why 
most people, if they would only acknowledge it, find celebrated places a little disappointing.

Of the regions where "nobody goes," this much may certainly be expected-they will be fresh. You will not know beforehand exactly what you are going to see, but it is sure to be interesting, for where the foot of the tourist does not tread, strange customs and old ways flourish undisturbed, and windows are opened into worlds far other than our own. Also-I cannot tell the reason, but I am very sure of the fact-there will certainly be something that is just as good as the hackneyed attractions to be found along the beaten roads of travel, if not far better -something very well worth going to, but fenced off from desecrating tourists' feet by the barriers, whatever they may be, that have made of the place a land where "nobody goes." Many and various are these barriers, in different places-extreme remoteness, want of comprehensive shipping services, bad climates, fevers, absence of roads, of hotels, of proper food, liability to destructive hurricanes, danger from uncivilised natives-these are among the commonest causes. The New Hebrides group has them all-yet it well repays every scrap of trouble, every hour of hardship inflicted upon those who invade its fastnesses; and the beauty and mystery and horror of the place will assuredly stamp their seal for life upon the mind that has once experienced them.

From the steamship company that maintains a happy-go-lucky service about the group, I obtained much kindly help and counsel. Even their people did not know anything to speak of about the interior of the islands, but they gave me useful hints about quinine and the like, and what clothes and other goods not to take, and where I should not go, and how long I should not stay. . . Advice about the 
islands seemed likely to resolve itself into a series of negatives.

It was an eight days' voyage up to Vila, in a decent little steamer that had only two passengers-island traders both-besides myself. As we were in tropic seas, and in a wild and strange part of the earth, interesting things should have happened during that eight days. They did not-save for the fact that the cook got drunk and struck work, two days out, and that the rosy-faced, smiling little captain went down to his cabin, mixed a deadly draught of all the most abominable and powerful drugs in the medicine-chest, poured together at random, and went forward toward the regions of the galley with the fearful brew in his hand-always smiling.

I do not know why one of the mates said there was a belaying-pin missing out of the rail, not long after; for the wise passenger does not intrude himself or herself into matters that are outside the passenger province. For the same reason, I must acknowledge ignorance as to why the cook did not die. I only know that there was a wild, weird dinner that night, whereas we had feared there would be none, and that until Vila was reached, the cook, unlike the captain, "never smiled again."

But even this eight-day voyage in an island steamer that takes no heed of the gospel of Clark Russell, comes to an end at last, and there arrives a morning when the sea is bright with the pale-blue dazzle of sun-smitten tropic latitudes, and the flying-fish are glancing and skipping about our bows, and Vila Harbour-surely the loveliest of all the fairy harbours in the wonderful island world-is opening out before us.

Very blue and green and vivid and tropical; very exquisitely set in peaky hills, and gemmed with 
enchanted islets resting like scattered emeralds on the turquoise plain of the bay-very far indeed above the poor art of the mere word-painter, even if word-painting were commonly read, which it is not-such is Port Vila, a harbour that may fairly take its rank with such celebrated beauties of the shipping world as Rio in Brazil, the Golden Gate of San Francisco, or exquisite Papeëte in Tahiti, the island of dreams. And it is well that the harbour and approach are what they are, for the town itself-the capital of the New Hebrides-comes with something of a shock on an unaccustomed eye.

Washington, capital of the United States, has been described as a city of magnificent distances. Vila, capital of the exceedingly disunited New Hebrides, may, in parallel fashion, be described as a city of magnificent omissions. It is principally remarkable for what is not there. Its splendid hotel, its handsome Town Hall, its pier and promenade, its public buildings-are still in the quarry. Its main street can be distinguished from the surrounding bush, with care and a pioneering axe, since it has something like a dozen different buildings, distributed over the course of a mile or so. The other streets consist of crazy-lettered boards, planted about uninhabited wilds, and declaring, in the teeth of probability, that this particular section of guava bush or cottonwood scrub is the Boulevard de Something, or the Avenue de Something Else. That is Vila.

On the summit of a high peaky green island, out in the bay, stands a big gray bungalow that shows prominently among the palms. This is the residence of the British Commissioner, Captain Ernest Rason, R. N. It is fashionable, in the New Hebrides, to live on an island by yourself, if you can, partly for coolness, and partly because the impulsive manners of the natives, in certain 
parts, are more easily kept in check when one can always see them on their way to make a call, and get out the afternoon tea and the Winchester rifles in good time. Most of the mission stations, and many small native villages, are situated on separate islets, about various parts of the group. It is a quaint custom, and adds much to the picturesque quality of the scenery.

(One of the passengers is trying to make the others believe that he saw the following house-agent's advertisement in a Sydney paper, not long ago:

"NEW HEBRIDES GROUP.-Most eligible residence for gentleman's or trader's family, now in the market. Exceptionally well situated upon the summit of an island $1800 \mathrm{ft}$. high, with splendid outlook over the adjacent cannibal country. The residence is well out of poisoned-arrow range, and two hundred yards out of shot of Tower muskets, but tenants possessing magazine rifles can enjoy excellent native shooting from their own door. The mansion is thoroughly up-to-date, and is replete with every modern convenience, including bullet-proof bedroom shutters, excellent hurricane cellar, and handsome, airy fever ward. Good dynamite fishing all round the estate. Monthly post, and yearly man-of-war. The punitive expedition season is full of picturesque interest, and mixed Governments flourish luxuriantly all the year round in the circumjacent country."

Was he speaking the truth? Well, I should not care to undertake a decision on that point. Strange things happen under the Southern Cross. But I do not ask any reader to believe more than he feels inclined for.)

The New Hebrides are a good-sized group of islands, thirty-five in number, varying from a few yards or acres to a couple of thousand square miles in extent, and covering a space of eight hundred miles of sea. The native population is variously estimated at 60,000 to I००,০০০, and there are about three hundred French 
settlers, and less than two hundred British and colonials - most of whom are missionaries.

The islands are extremely beautiful, and remarkably fertile. Three crops of maize a year can be raised with little trouble. Coffee is largely grown, and there is none better in the Pacific. Millet, for broom-making, grows readily and pays well. Copra can be produced in the New Hebrides to better advantage than in any of the British Pacific colonies, the Solomons only excepted. Eighty nuts a tree is considered a very good average over the greater part of the South Seas. In the New Hebrides, the figures I received seemed almost beyond belief, but even allowing for much exaggeration, it seems certain that the average yearly crop of nuts must be quite twice as large as in Fiji, the Cook Islands, or Tonga. I saw more than one tree that had three hundred nuts at once upon it (as I was informed; I did not count them, since that would have involved going up the tree with a paint-pot and a brush to mark them off), and I heard of one or two that had four and even five hundred.

This is a more important matter than might appear at first, for the copra trade is the true gold-mine of the Pacific. The oil that is expressed from the dried nutkernels is used in many different departments of commerce, especially soap-making, and the demand constantly exceeds the available supply-so much so, that the well-known firm of Lever Brothers have been buying up large tracts of land in the British Solomons, to keep their factories supplied.

On the whole, though they are mostly uncleared as yet, these islands are quite worth having from an average trading point of view. But they own other advantages, less apparent on the surface-to us, though evidently not to others. 
For no less than fifty years, a tug-of-war, more or less polite-at present, on account of the entente cordiale, decidedly "more" - has been going on between ourselves and France over the possession of the New Hebrides group. I really cannot say why England has not allowed France to take them over long ago-it is, however, certainly not because she understands either the true significance of the question, or the inner meaning of the attitude assumed by the rival claimant, for the absence of all attempts to support British interests in the islands, and the easy manner in which every point of importance was passed over on the occasion of the late Anglo-French Convention, furnish only too much proof to the contrary. One inclines to suppose that John Bull has simply let matters slide, so far, because he does not care to be troubled, and it would be troublesome to come to a decision one way or the other.

Here is the history, in brief, of the disputed group. It was discovered by the Portuguese De Quiros, in I605. The subsequent exploring, charting, and naming was carried out for the most part by Captain Cook, though the French captains, Carteret and De Bougainville, also visited the islands during the Eighteenth Century, and explored certain parts. The islands were given their present name by the great English explorer, who, on the same voyage, discovered and named New Caledoniaa rich and valuable country which was allowed to pass without opposition into the hands of France, in the early Nineteenth Century. Before this annexation, no one seemed very anxious to acquire the New Hebrides group, but from the occupation of New Caledonia, the lesser place began to come forward. Up to $\mathrm{I} 878$ the settlers and missionaries were almost entirely British. In that year, however, an agreement was entered into with 
France to recognise the independence of the islands, France herself undertaking to do the same. (It is a fact worthy of note that, in spite of this, six years later France was negotiating with Germany to make arrangements by which Germany should agree to the establishment of a French protectorate over the group.) In I886, France proposed to exchange the small island of Rapa, in the Eastern Pacific, for the right to annex the New Hebrides. Lord Granville was willing to accept the proposal, but the Australian Premiers remonstrated so strongly that it was finally refused.

From 1878 onward, an infusion of French settlers and missionaries began to flow into the New Hebrides, and every effort was made by the French Government to strengthen their hold on the country. The result has been that the French population now outnumbers the British; that the commerce of the group is heavily handicapped where English and Australian settlers are concerned, and is heavily subsidised in favour of the French; that British interests are everywhere going to the wall, and that the French are openly expressing their intention of acquiring the whole group, now that the Anglo-French Convention has so obligingly agreed to uphold the status quo ante. That, they declare, is all they wanted; time will do the rest.

And now for the inner meaning of it all. Why does France so ardently desire to obtain possession of a rather unimportant island group in an out-of-the-way place, that she spends many thousands of pounds a year in the subsidising of traders, settlers, and steamer companies, and brings all the heavy artillery of her famous diplomatic powers to bear on the maintaining of a paramount position among a handful of cannibal savages?

For three excellent reasons: First of all, because 


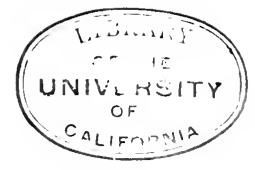




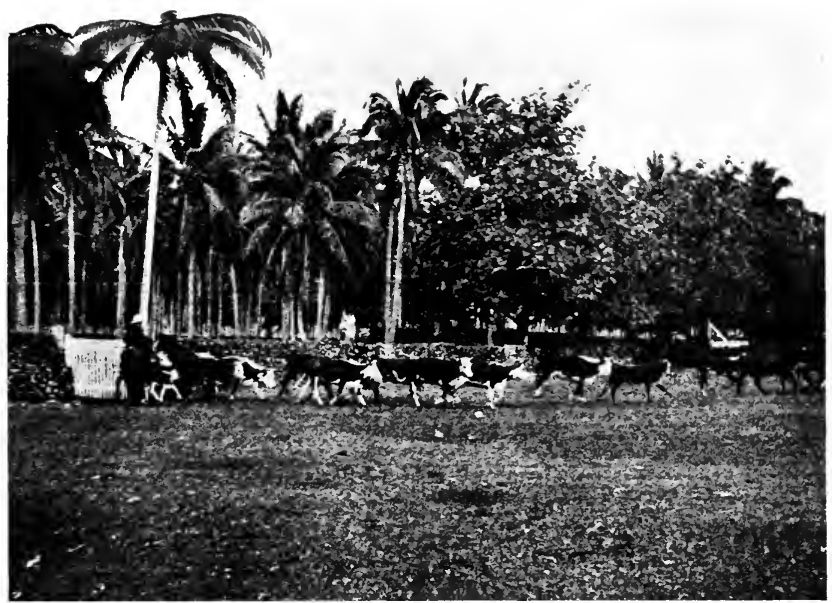

ENTERING THE STOCK-YARDS

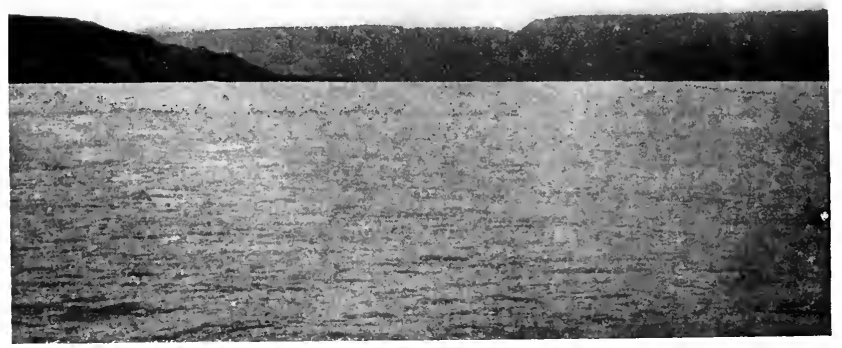

HAVANA HARBOLR. EFATE 
New Caledonia-that rich plum among island countries, a land three hundred miles long, containing almost every precious and semi-precious metal-cannot be securely held without the New Hebrides group. The latter is eminently fitted for the establishment of a naval base, and contains three magnificent harbours, which neither New Caledonia, nor any place within thousands of miles, can match. Secondly, the opening of the Panama Canal route will bring the islands so much nearer to the great trading highways, that they will become more important than they are at present, both from a strategic and a trading point of view. Thirdly, New Caledonia is not a grain-producing country; the New Hebrides group is, and the other needs it as a permanent granary.

All in all, the problem resolves itself, for France, into the fact that the permanent loss of the New Hebrides will probably mean the loss of New Caledonia as well, and, incidentally, of an excellent site for a naval base. For us, it means that the loss of our rights would place a hornet's nest belonging to a rival power at the gates of our most important, and least effectively defended colony, that British trade would be driven out of the group, and that a stronghold which is really needed by us as an offset to the naval base lately established by Germany in New Guinea would be taken from us.

At present, the islands are in the most uncomfortable and unsettled state it is possible to conceive. There is no other place in the world where an uncivilised coloured race is to be found in an entirely self-ruling condition, owning no real master, and not even "protécted" by any of the great Powers. At the time of my visit last year, Monsieur Borde, the French Commissioner, and Captain Rason, the British, could not pass laws, or hold courts of justice; and there was actually no law 
of any kind in the group. If a native murdered a white man, the only redress was of the "might-is-right" pattern, and was usually applied by the next man-of-war that happened to come along. If a white man injured another in any way, there was no legal redress at all. It was certainly a curious experience to stay in a place where murder, assault, or robbery were perfectly permissible diversions, for any one who might fancy such forms of amusement, and still more curious to see the quiet and orderly manner in which life actually went on, without the usual machinery of law and government to keep it in order. Even the New Caledonia ticket-of-leave element, of which there was more than enough, did nothing worse than get drunk, and scandalise the Grundian proprieties. All this, too, in spite of the fact that rifles stand loaded in the house of every white settler, "in case" - and that disputes over the ownership of land are unpleasantly frequent. . . . A strange state of affairs -Alsatia and Arcadia combined. There ought to be a useful moral attaching to this, I am quite sure, but I have never been able to find it-which is a pity, because morals of all kinds, in the tropics, are like ice-valuable, scarce, and evanescent, and therefore not to be wasted.

In the spring of 1906 , some time after I had left the islands, the Anglo-French Convention, at that time sitting in London, came to certain decisions about the New Hebrides. It was arranged that a mixed commission should consider the various disputes about the ownership of land in the group, and that courts of justice should be held for the trial of offenders, when necessary.

Regarding the question of annexation, no progress whatever was made. It had been hoped that some division of the islands, at least, might have been proposed, but the entente cordiale evidently stood in the way, 
where vexed and thorny questions were to be discussed, and the upshot was that in all essential matters, the islands were left as they had been before-no man's land at present, and France's land by-and-by.

There is no use in commenting on such a state of affairs, since the conclusions to be drawn therefrom are plain enough to anyone interested in matters of the kind. But it is, perhaps, worth while observing that the effect on the progress of the islands toward civilisation is, apart from political questions, entirely blocked by the absence of all real authority over the natives. I do not think that the most fervent advocate of the rights of the natural man could uphold the claims of the untamed New Hebridean to the freedom of his forefathers, or sentimentalise in this case over the "noble wild man" doomed to bow beneath the yoke of an oppressive civilisation. The New Hebridean, in his native state, is neither more nor less than a murderous, filthy, and unhappy brute. Tamed, cleaned, restrained from slaying his acquaintances either wholesale or retail, and allowed to live his life in peace on his own bit of ground, he is a passable poor relation of the Maori or the Zulu, and can even get on comfortably with his white neighbours, growing and drying copra for them to buy, or doing a little casual plantation work, and so collecting enough money to furnish himself with tobacco, matches, soap, cotton-stuff for the minimum of clothing that he wears, ship's biscuit and tea and a bit of tinned salmon now and then, a rough lamp for his hut and oil to burn in it, and a pot or two for cooking. These are practically all the luxuries of civilisation that the average islander has any desire for, but their possession marks an immense stride in the scale of progress for the "reclaimed" native who gets so far. 
At the present date, there is the merest fringe of such life, scattered about an impenetrable mass of utter barbarism. The missionaries, in sixty years' work, have contrived to tame down completely a few of the smallest islands, and to make a little impression here and there upon the edges of the larger ones. But, in spite of the work done by missions, the fact remains-patent to all who have seen the islands as they really are, both on and off the steamer routes-that the New Hebrides will never be completely tamed except by force. Once that is done-once the power of the mountain and bush tribes is thoroughly broken, and their prestige among the lowlanders taken quite away-the work of the missionaries will go on toward something more like an encouraging result than it can show to-day. The lives of the white settlers will be safe; property will be secure; trade will be uninterruptedly carried on, and the group will be twice as well worth having as it is to-day; while into one of the darkest spots on the surface of the earth, the light of civilisation and decency will have been carried.

I do not wish to minimise the work of the missionaries, though one must allow that there is a good deal less of the martyr about it, even here, in the worst of the Pacific Islands, than the popular fancy imagines. But one would certainly wish to see it carried on hand in hand with the work of a strong and able government, which could forbid the sale of poisonous spirits to the natives, disarm the tribes, compel traders to cease selling rifles and ammunition, and impartially punish all offenders, white or black. This has been done to a great extent in the British Solomons, and could be done in the New Hebrides without any real difficulty if they were once annexed or partitioned. 
Various proposals have been made by Australia and New Zealand from time to time, with the view of settling this long unsettled matter. Australia has certainly little right to talk, since she has of recent years practically ruined British trade in the New Hebrides, by imposing heavy duties on all island produce that enters her ports. However, one of her propositions, made a couple of years ago in an unofficial manner, was that New Zealand should give over the Manihiki Islands to France, for the undisputed possession of the New Hebrides. No one seemed to be aware that the suggestion was entirely impracticable, and even insulting to France-since the Manihiki Islands consist simply of two small coral atolls, each a mere strip of barren land circling about a central lagoon some four or five miles long. Mr. Seddon, just before his death, suggested the exchange of Mauritius for the group. This was a better idea, but it missed the main point of the difficulty - that the New Hebrides and New Caledonia must be considered dependent on each other, and that any offer of exchange should be based on an acknowledgment of this fact. In any case, the French refused to consider it.

French opinion in the group is plain. Whatever the official utterances of France may be as to the absence of all desire to annex, they are not upheld by the colonists, by authorities in New Caledonia, or by the local press. All these are loud in urging annexation, and jubilant over every move that tends toward the desired end. Pressure of an unobtrusive sort has been put upon British colonists of late. The English or Australian settler often finds his way a hard one, unless need or greed drives him to discard his nationality, and take out French papers of naturalisa-

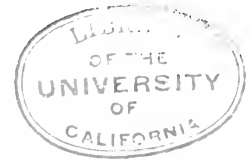


tion. Then all is smooth. Duties are in his favour, instead of against him, subsidies help him out, enemies become friends. . . The astonishing thing is that the British colonists, so far, have taken next to no advantage of this state of things. Their flag is an expensive luxury, but they stick to it. 


\section{CHAPTER IX}

\section{THE NEW HEBRJDES}

New Hebridean Natives - Life in an Explosive MagazineThe Delights of Dynamite Fishing-The Sapphire and Snow of Méle-On a Coffee Plantation-Plan to Eat a Planter-The Recruiting System-The Flowering of the Coffee

DOLITICS apart, it was the Islands again, and I was glad, for I had learned to love the island world. Yet it was not the Islands as I had known them, in the dreamy Eastern Pacific, and in quaint Fiji, the link between East and West. Where were my island friends, my sunny-faced, subtle-minded brown Tongans and Samoans-gay Aitutakians, Raretongans, Manihikians, pleasant folk of Kandavu and Mbau, comical Niueans, lovely women of far Tahiti, with their rose and lilac tunics, their welcoming songs, their merry laughter? I1l substitutes indeed were these ugly creatures with flat savage features and unkempt hair, paddling silently about the ship in ill-made log canoes, wearing scarcely a rag apiece, and staring at the strangers with sulky ungenial faces? Most of the men had rifles on their shoulders, and bandoliers of cartridges across their naked chests. All were silent, sullen, ugly.

The Islands-yet not the Islands, as I had known them, for $\mathrm{my}$ island friends were not there.

Coffee-coloured gentlemen of the Western IslandsFijian chiefs with manners that would not disgrace a 
royal drawing-room, and wise, kindly, well-bred faceswho could classify you in the same scale of creation as these gorilla-like creatures? It is true that in Vila, nearly all the natives one sees have been civilised and Christianised, after a fashion, at the hands of the Presbyterian or Catholic missionaries. But in many cases the Christianity is wearing very thin, and constant association with the unregenerate heathen of the plantations, who are usually recruited from the cannibal islands further north, does not tend to strengthen what little piety the converts possess. The popular idea of the New Hebridean, for a wonder, comes very near the truth. He is supposed to be, and is, treacherous, murderous, and vindictive. $\mathrm{He}$ is to the full as sensual and indolent as the Eastern Islander, and lacks almost every virtue possessed by the latter. $\mathrm{He}$ is almost inconceivably clumsy and stupid in a house, or on a plantation; almost devoid of gratitude, almost bare of natural affection; ready to avenge the smallest slight by a bloody murder, but too cowardly to meet an enemy face to face. Yet there are a few things to say in his favour. $\mathrm{He}$ is wonderfully honestso much so, that in the bush districts, a coin or a lump of tobacco found by the wayside will never be appropriated by the finder, but will be placed in a cleft stick at the edge of the track, for the real owner to take next time he may chance to pass that way-and if the possessor never returns, the "find" will remain where it has been placed until some white man, or some "civilised" native from a plantation, passes by and appropriates it.

In some cases, the New Hebridean is found capable of receiving education, filling the post of plantation overseer, or learning to be a good house servant; though 
such instances are very rare. The people of Aneityum and Erromanga, being Christianised and civilised as far as is possible to the race, have reached a general level about equal to that of an intelligent English child of five or six; Vila is quite a civilised spot, as far as it goes, and in none of the Christianised districts of the group is any malicious attack to be feared by the traveller.

For all that, the capital and the small settled districts on the other side of Efaté are not quite the safest places in the world. People who are nervous about firearms assuredly cannot enjoy a happy existence there. Every native has a gun, and almost every one carries it-loaded, cocked, and slung about at every conceivable angle. It is only intended for pigeons and flying-foxes, but that it does not bring down nobler game any day in the week is emphatically a matter more of "good luck than good guidance." Some weeks before my arrival, a Vila trader, peacefully parting his hair before the glass, was interrupted by a rifle bullet, which sang across his room, and buried itself in the wall beside the frame of the mirror. The trader, not being troubled with nerves (few people are, in the New Hebrides, else they would not be there), calnily finished his toilet, and then picked the bullet out of his wall, as a trophy. Not long after, the Vila missionary gave a party, and asked some people over from the mainland. They arrived rather late for tea-giving as explanation the fact that they had been peppered with rifle bullets coming across! As they could not make out where the shots were coming from, they thought it best to take a round, though convinced that no malice was intended. This kind of thing is fairly frequent; but little harm has yet been done, and no one seems to mind.

"It is rather like living in a nursery full of naughty 
children, all armed with cocked and loaded guns, which you mustn't take away from them," observed the British Resident Commissioner to me one day.

It was rather more like living in an explosive magazine, to my mind. As the islands belong to nobody, and the British and French Commissioners are only there to hold a "watching brief" for their respective countries, without possessing any real governing power, the native is free to follow his own uncivilised will, in the midst of stores filled with firearms, ammunition, and explosives of many kinds-all of which are specially intended to charm the hard-earned plantation wages out of his pocket. (Yes, he has a pocket, though sometimes it comprises almost all his clothes, with a boar's tusk on the breast, and a pig's tail in each ear, for style.) Dynamite, for fishing purposes, is sold by the stick as freely as tobacco, and handled without the smallest care. Percussion caps, loose gunpowder for the old-fashioned muskets that so many natives own, cheap sulphur matches, and cartridges of many kinds, seem to be necessaries of life to most of the islanders, and are stored anywhere and anyhow. It is not much to be wondered at that one-armed and one-handed men are rather common sights about Vila, nor that the piles of squared coral stone that mark the native graveyards, under the seaward-looking palms by the shores of the green lagoon, should hide beneath their rudely fashioned cairns the tale of many a worse disaster.

"Dynamite fishing is real good sport, but it's a nice job, mind you," observed a member of the Australian trader family with whom I had arranged to board during my stay in Vila. "I'm pretty good at it myself, but I've seen things happen. . . . There's some of them at 
it now; there's always a few out. Come on the back veranda and I'll show you."

I went out as requested, and saw the commonest sight of Vila Harbour-a canoe lying in the water near the shore, a native putting a match to something, and throwing it into the sea; a dull booming explosion and a fountain of updriven water, and then a scrambling and scooping over the side of the canoe.

"So that's dynamite fishing?"

"Yes. Capital fun too. You put a bit of fuse on to the end of a stick of dynamite-a short bit, mind you-and then you light it and chuck it away. It kills a lot of fish, if it explodes close enough to the water. The natives cut the fuse too short, sometimes, they're that careless, and then things happen. One wants to cut right, and throw right. If the fuse is too long, the sea will touch it before it's had time to explode the cap; and if you throw too far away, the explosion's over before it nears the water. Some fellers they "sky" the stuff, so's they can let it have a longish fuse, but I know a cove who skied it too straight, and got it right in the boat again. What happened? Well, what 'd you expect? . . . The sharks were handy about, and they cleared up the mess. Another feller, he bit the ash off the fuse with his teeth, and the native boys that was left in the boat didn't think it worth while bringing of him home without his head, so they took the boat and scooted to their own island. I know all about it, though, and you'd better come out with me if you'd like to learn. It's worth your while, too, for you can't do it in most islands; governments, when there is such a thing, always puts a stopper on it right off."

There is a trader in Vila to-day who has a very poor opinion of the courage of Englishwomen-I shall not 
say why. But-I have never learned to fish with dynamite, and I am still happily possessed of both my arms, and all my head. And, now that many months have passed since I sailed away from the explosive New Hebrides, I find myself able at last to avoid the insane tendency to pick up my skirts and hurry inland, that used to beset me at first, whenever I saw a harmless boatful of fishing excursionists, gliding along a placid British shore.

But, after all, Vila and its surroundings were not what I had come to see. So, after a week or two spent in the "capital," I decided to leave behind its stores and street, its lumbering drays laden with sacks of maize and coffee for the steamer, its Continental-looking restaurant and café, its smart, sallow, well-dressed women (a Frenchwoman will "make her toilet" even in the Cannibal Isles) - and ride away into the bush, where the coffee-growing count $y$ was, and one might see New Hebridean plantation life at its worst and best.

The morning was dim and pearly, and the harbour lay in long unruffled levels of crystal-gray, under the shadow of green, gold-crested islands, when

No, I cannot tell a lie. That was certainly the time of day, and the scene that should have witnessed our setting off. It would have been, in any decent book. But we didn't set off in a book, my two English planter escorts and myself. We set off in the actual dust of the scorching Mélé road, at half-past eleven instead of six, just when the sun was at its very worst, the green islands gray with heat, and the harbour almost too glaring to look at, from under the brim of a wide-leafed plantation hat. And if anyone wishes to know why, that person had better try how long it takes to get 
three people and three horses off in the morning, when there is a big journey ahead. If he has tried, he will not need to ask.

Undine Bay was our destination, thirty miles away, and we all carried our goods with us-baskets and saddle-bags containing clothes, food, billy-cans, and other et ceteras, so that we looked, as we cantered along the dusty track in single file, like Alice's White Knight multiplied by three. Our horses were nothing to boast of. Mine, not to embroider upon the humble truth, was a cart-horse, nothing more. Indeed, one might well have wished him less, for he was certainly over sixteen hands, and had the paces of a hippopotamus, but he was the only four-legged beast to be had for hire in Vila, so choice there was none. Of his various iniquities during that long, long, burning ride-of his utter disregard of whip, heel, or rein-his iron neck and jaw of cast steel-his unpardonable habit of trying to scrape me off, like an inconvenient barnacle, under the boughs of thorny lemon-trees-his blunder-headed trampling on, after a million-hooked "bush-lawyer" vine had fished for me anl caught me, and was tearing agonising bits out of my flesh-his heavy-hoofed slidingdown nightmare descents, and low-bred, snorting panic in deep boggy fords-of all these, I shall say nothing The "gentlemen of England, who sit at home at ease" -on properly broken horses, and never know from the cradle to the grave why you carry a tomahawk in bush riding, and what happens if you, or your escort, don't use it quick enough-these pampered people would not understand. . . Yet we who have experienced such things are the happier, for it is in the Anglo-Saxon blood, gentlemen; and some of you who read unis page without understanding, will come to your own one day with 
the creak of the high-pommelled saddle under you, and all about you the scent of the unbroken forest where no man's foot has passed. Then you, too, will know.

I had travelled the South Seas over and over before I came to Efaté, but never from Papeëte to Penrhyn, and from Tutuila to Savage Island, had I seen such colouring as I saw that day on Mélé beach, where we rode along the shore before we turned into the forest. It was an immense beach of powdered coral, miles long, and hundreds of yards wide, and it was so exceedingly white in the raging sun that its scoops and shadows were blue of ultramarine, like the shadows on a plain of snow. You could see the colour of the air as you rode across this wide white plain, and it was blue, clear blue, as though you swam in water. Sapphire and snow was the whole marvellous picturethe foreground was one huge sweep of blinding white, the mountains far away were blue, the sea was blue the sky was blue-the shallow lagoon was shot with unnameable hues of changing hyacinth, and Mélé island, floating on a crystal plain, was one entire and perfect turquoise. . . . A very miracle of colouring, flung down by Nature like a gauntlet of defiance in the face of the luckless traveller whose trade it is to juggle with words- "Draw that; tell that that, if you can!" ran the challenge. . . . Spirit of wonderful Mélé! I have not told, for I could not.

After we left the beach of Méle, we rode for ever and for ever, or so it seemed, through the bush, over narrow foot-tracks that only admitted our party in Indian file. The light was $\operatorname{dim}$ and green most of the day, for the New Hebridean "bush" is true tropical forest, and the sun cannot pierce its dense roofing of 
leafage and knotted liana. Great banyans, their outrunning branches supported by companies of closeranked pillars, made strange imitations of shrines and temples in the shadowy depths of the wood. Enormous trees, whose names I never knew, shot up dark colossal trunks with plank-partition roots buttressed as high as our heads. Leaves of the wild taro plant, sappy and juicy, lifted giant hands of green, as large as a tea-table, on nine-foot stalks. Strange reddish figs, odd pink and yellow berries, showed in the undergrowth, some poisonous, some good for food; and wild nuts and almonds of many kinds, without a recognised name, crackled on the ground under our horses' hoofs.

At night, nearing our destination, we plodded across a plain of dry rustling reed-grass, where wild boars, feeding upon wild yams, crashed and snorted aside at the sound of our horses' hoofs. Roast pig and roast potato, fat parrots and wood-pigeons; cocoanuts, almonds and fruit in the woods; fish from the lagoon - when the uncultivated land and unrented sea provide so much as this for the mere trouble of taking and cooking, can it be wondered at that labour for the white man's plantations has sometimes to be recruited by methods that do not exactly send up a sweet savour to heaven?

Plantation life in the New Hebrides, however, is peaceful and pleasant enough-on the surface. When you live very many miles from your nearest white neighbour-when you and your black labourers are cut off from all the rest of the earth by a belt of densest jungle on one hand, and a bar of sailless sea on the other-it comes about, for the most part, that you grow to be easily pleased, and contented with little. The planter's wife and family are far more to him than 
the city man's; they are all his social circle-it is his own sons who smoke and talk politics with him in the evenings, and his own daughters who make concerts with the old harmonium and the new violin, and hang out spring exhibitions of pictures on the walls, and get the new books and magazines down from Sydney to make a small "home literary circle," all under the one galvanised-iron roof. And the mother-well, there is time to recall the long-gone hours of youth, in these endless island days; and women, for all the fever and the climate, and the hard work over hot stoves that cannot be left to the charge of native servants, don't lose their charm in the isolated plantation life as fast as they lose it in the rush and strain of society. . . . Yes, they keep their complexions better in Melbourne or Wellington, and there is a smarter twist to a ribbon, down there, and a more fashionable coil of the hair, but . . Nature knows many things she does not tell to the city-dweller, and it's not so lonely in the bush after all, for a married pair who learned long years ago that they have made no mistake. For the others--well, you do not find them in the lonely forest homes. $\mathrm{He}$ is trading somewhere along the coast; she is with her friends in Sydney, because the children must be educated, and the islands never suited her health, in any case. There is nothing like the bush for testing to its farthest limit the strength of that "silver link" and "silken tie."

Very early, in the brief cool hours of the day, the planter and his sons are off on their horses, after a cup of the fresh perfumed coffee made from berries gathered in the woods below. All morning they are walking and riding about, overseeing the labour, giving orders as to pruning, planting, gathering. At 
midday they ride home to a bath and an early dinnersalt meat, tinned meat, or a bit of goat for a treat; wild tomatoes and peppers; a pudding made from the arrowroot that grows in the garden (and if you think, you people in Europe, that you get real arrowroot when you pay for it, come to an island plantation and learn the difference); oranges and bananas, also from the garden; baker's bread, made by the ladies of the house, who are the only cooks. . . . One is not luxurious, on a coffee plantation, but there is all a man may reasonably want.

The heat of the day is now at its worst, and the planter takes a nap in his long chair, while his wife, tired with cooking, dozes on the cane sofa. The daughter says she is going to have an attack of fever, but will be out for tea-and goes off to her own room to spend an unhappy few hours of sickness and shivering. Every one expects a dose of this kind now and then, and takes it as all in the day's work. There is not much fever on this especial plantation, but on others lower down it is so bad that a yearly visit to the colonies is a necessity, to keep the owners in passable health.

Evening sees the men back from a second ride about the estate, the daughter recovered, tea on the table, the sun down, and the short tropic day over. Byand-by there will be music; at present, there is talk. Not of "news"- the green rampart of the forest and the blue bar of the sea shut off all the outer world, and save at steamer-time once a month, empires may rise and fall, and kings may die, but the plantation knows not of it. The talk is of the happenings of the dayand startling enough some of them are, to a stranger ear.

"That big chap from Sou'-West Bay is sick-tree fell on him." 
"Is he? The fellow that tried to axe me last week?" "Oh no, not that one. It's the fellow you found sneaking behind the cook-house on Sunday morning."

"Hope it'11 keep him out of mischief, then; he's as cheeky as they make them. He'd no business at the house."

"Hadn't you better shift your bed?" asks one of the ladies, sugaring his tea.

"No, rather not! sick or well, he's a rotten bad shot."

I ask for an explanation, and am told that the labour imported at a wage of forty shillings yearly from the wild cannibal parts of the group, grows unmanageable at times, and is prone to avenge small slights by shooting its employers-preferably after dark, through the bedroom window.

"No one likes that fellow, I think," says the daughter of the house, conversationally. "Why, it was only the other day that I caught Ata, the kitchen-girl, putting rat-poison in his rice to kill him. I'm afraid she's an ill-natured girl herself."

"What did you do? and don't you think she may poison you some day?" asks the guest with interest.

"Oh, I boxed her ears, and threw away the rice. She won't poison us; of course, we keep the poisons locked up-I really don't know how she got at that!"

"Our boys aren't a bad lot, but I do think young $\mathrm{X}$ - might be a little more careful with some of those he's got," observes my host. "He lives down in the bay, you know. An Aurora man of his has laid for him twice with a tomahawk-fellow that has murdered three natives already-and $\mathrm{X}$ - has him as houseboy, just to show him he doesn't care. Of course, one doesn't want to send away a good strong boy because he's made a swipe at you with an axe, or lifted a gun 
at you, but it's more sensible not to have him in the house when you live alone, as he does."

"Q- was uncommonly near getting it from one of his lot," observes the son, spooning guava jelly liberally on to his plate. "It was quite a funny thing. Seems they'd planned to shoot him from the scrub, and take his body off into the bush to eat ( $Q-$ never could make his men respect him, to my mind), and I'm blessed if the cunning beggars didn't clear a path ready to carry him away; cut it all but the last yard, and left that to hide the opening. Well, Q- had a friend who happened to turn up in a boat all the way from Vila for a call, that very day, and the two of them were walking about the estate together the whole afternoon; and every time the beggars hid in the scrub tried to pot him, the friend happened to be in the way! $\mathrm{Q}$ - heard all about it afterward, and he simply roared. So, when they found it was no go, they got tired and cross, just like they do, and they agreed they couldn't be bothered to shoot him, but they'd steal his boat and run away. And they did, and $Q-$ never caught them. Funny story, wasn't it?"

It was just the day after this, that an invitation arrived from the plantation of the gentleman whom I have called $\mathrm{X}-$, to luncheon at his house. It was within fairly easy riding distance, so all my host's family took a holiday, and we rode down in a body. Mr. X- was a young Oxonian, not twenty-four years of age, who had been through most of the Boer War, and found himself unable to settle down to an office life at home, afterward. Accordingly, he bought a plantation on Efaté, and started out, with the assistance of two other youths (all three under age at the 
time), to handle some dozens of untamed cannibals, run a good many acres of coffee and millet, and, like the virtuous youths in the stories, to make a fortune. The fortune, owing to the duties lately levied against all New Hebridean produce by Australia, has not yet come, and the white partners have taken up other employment. But this adventurous young Englishman remains alone among his men, managing the plantation without help, and quite convinced that good luck is not far ahead. . . . These are the things that mere schoolboys of the British race can do, when you take them away from the grandmammas and aunts at home, and turn them loose in the wilderness to shift for themselves.

We had lunch, and a very good lunch too, in the planter's little one-storied bungalow-built by those three adventurous boys a year or two ago, when they first took up the land. They lived meantime in a refuge close to the site of the present house-a cavern that might have come straight out of the illustrations to a Ballantyne boy's book-big as a church, hung with tapestry of trailing green vines at the mouth, and fitted inside with a natural table and beds of rock. Did ever three lads in their teens enjoy a more complete realisation of a "story" life?

The lunch was not at all badly served, by a fierceeyed, sullen fellow in a very clean shirt and kilt-who, as our host triumphantly assured us, was the muchdiscussed murderer himself.

"That's what you call local colour, I suppose," said one of my hosts, evidently pleased to have the institutions of the country shown off for my benefit. (The murderer snatched over my shoulder for my empty plate. He was a good waiter, but rather brusque.) 
I agreed that it was.

The "blackbirding" days are gone in the New Hebrides-the gay old times when recruiting schooners simply kidnapped the men they wanted, and sold them outright wherever they chose. Nowadays, the menof-war, and the High Commissioner of the Western Pacific (who lives in Fiji, six or seven hundred miles away), keep a general look-out over the labour trade, and any captain who carries off unwilling natives by force runs serious risk. Further, the French and British Commissioners at Vila have made certain regulations (which is very funny, when one comes to think of it, because there is no legal machinery, at the time of writing, for enforcing them), and these regulations enact that the plantation labourers shall be sufficiently fed, honestly paid, and allowed to return to their own islands at the end of their three years' engagement. If not-well, there is, so far, no court and no prison in the islands. One must suppose that the Commissioners would simply "tell the man-of-war of you. if you don't behave." They might do worse. A naval captain has remarkably extensive powers, in such out-of-the-way places, and what he hasn't, he takes.

Still, in the lonely jungle clearings of these great islands, the planter is able to act very much as his character inclines him to do. Who is to tell?

My hosts were kind to their labour, though they did not treat them with any approach to sentimental indulgence. But there were other stories. The British settlers are not all saints, and the French planters are not taken from a good class, for the most part-indeed, there are whispers of ticket-of-leaveism here and there. Some are good fellows, humanely inclined, some arenot. Let it be allowed that the New Hebridean is 
a devil, and a murderous devil at that-it does not improve even a devil to underfeed him, abuse and flog him for the smallest cause, and count his life worth nothing more than the few pounds you have paid the schooner captain for recruiting him. And there are plantations on Efaté where all these things are done; there are dark stories of natives kicked or beaten to death, or so ill-used that they have been driven to kill themselves; of children "recruited" in far-off parts of the group, and sold into actual slavery for life; of house-servants so badly treated that the decent French and English settlers will hardly enter the bungalow where they are employed. In truth, a solid, settled government of some kind is badly needed, on parts of civilised and Christianised Efaté.

It would be untrue to say either that the labourers are enslaved, or that they are absolutely free. A New Hebridean from the wilds of the bush goes off with the recruiting schooner very much as an English rustic takes the shilling-for the most part, because he wants to get away from home at any price, and does not care what comes after. Like the rustic, he is usually rather sick of his bargain when he fully understands what he has done, and would be only too glad to get out of it if he could, before the end of his three years' term. Fear of being murdered by some personal enemy in his own village is the commonest cause of his offering himself to the schooner; sometimes, however, the small wage of two pounds or so a year is the attraction, if he sees no other way of obtaining that vital necessity to a full-grown New Hebridean - a rifle and a stock of ammunition. Sometimes the recruit is forced into the bargain by powerful relatives, who desire to secure the presents commonly 
given to the family of each man. Often enough, he is more or less deceived by the flowery representations of plantation life furnished him by the recruiting captains, who commonly, though not always, obtain a ten-pound bonus for every man they deliver. Under proper conditions, however, and vigorously overlooked, there is no reason why the New Hebrides labour trade should not be carried on in as just and satisfactory a manner as the Solomon Islands labour trade with Fiji. There will always be men ready to engage for the plantations, especially if the wages and food could be made a little better than they are; and with effective supervision, the blots that at present disgrace the system would vanish. Even as things are, a good employer will find the same men re-engaging now and then on his plantation-though very seldom without an interval spent in their own islands, at the end of the first three years.

I had only been a week or two with the hosts who had asked me over from Vila (entire strangers to me, but exceedingly kind and hospitable), when a message came over from another plantation to the effect that the $\mathrm{R}-\mathrm{S}$ had had the visitor long enough, and they were to send her over to the S- - , for it was their turn now! The $\mathrm{S}-\mathrm{S}$ were total strangers also, and, like the $\mathrm{R}-\mathrm{S}$, had only incompetent native servants, so that the arrival of a guest meant considerable trouble to the family themselves. But the hospitality of the islands passes lightly over such trifles-even over the circumstance of having to turn a daughter out of her bed, and leave her to sleep on the floor, while the stranger guest, cuckoo-like, occupies the couch from which she has been thrust away!

It was on the S- plantation-one of the loveliest spots in an island where every prospect was certainly 
pleasing, and only the plantation hand was vilethat I saw for the first time the wonderful picture of fleeting beauty presented by the flowering of the coffee.

A coffee plantation, at any season, is very like a huge ornamental shrubbery. Its pretty bushes, with their polished dark-green leaves, are quite unsuggestive of commerce, and the scarlet cherries, of which the coffee "bean" forms the stone, light up the close-set foliage as effectively as the holly-berry lights its tree. But the flowers are the true glory of a plantation. Once a year they appear, and they last for three days only, from the bursting of the bud to its withering away-for but one day, in perfection. All at once, the whole shrubbery breaks into sprays of heavy snow, and the air is filled with a cloying hothouse sweetness-the coffee blooms are out! A little like stephanotis, a little like gardenia, sweet as tuberose, white as orange-blossonthere is surely nothing in the tropics more lovely than the fair and fleeting coffee flower. Who first thought of bending such a poetic tree to the uses of commerce? Who divined that the ugly little stone in the scarlet fruit that was child of the wax-white coffee flower, would make a drink fit for the gods? - . . I shall like coffee all my life the better for having seen its beautiful beginnings. Even the ugly untidiness of the pulping-pits, where, in the season, the berries are crushed and stirred under a stream of water, to detach the stones, and the arid desert of the drying-trays, scorching in the sun, cannot altogether deface the memory of the lovely blossomtime, when all that Milky Way of scented stars breaks out in the tropic dawn, to its one day of perfect life.

Successful as some of the New Hebridean planters have been, one cannot conscientiously recommend 


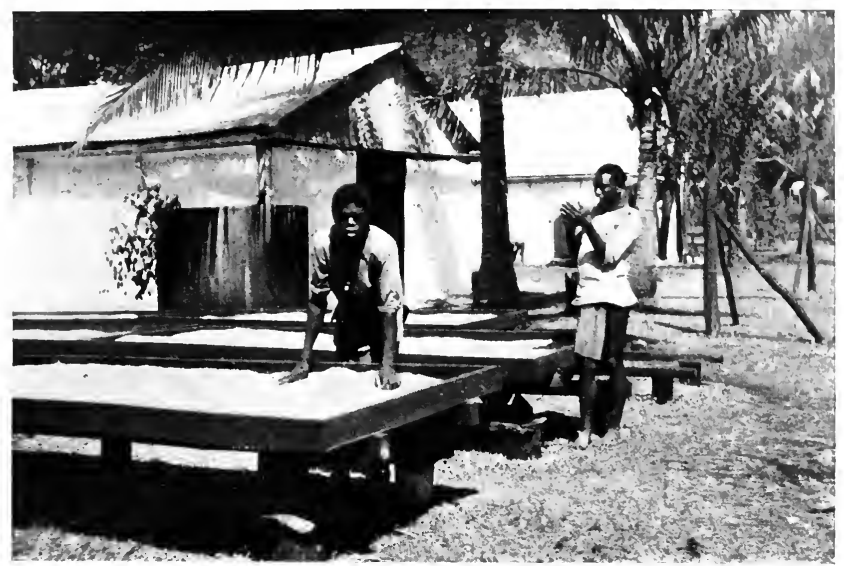

COFFEE-DRYING

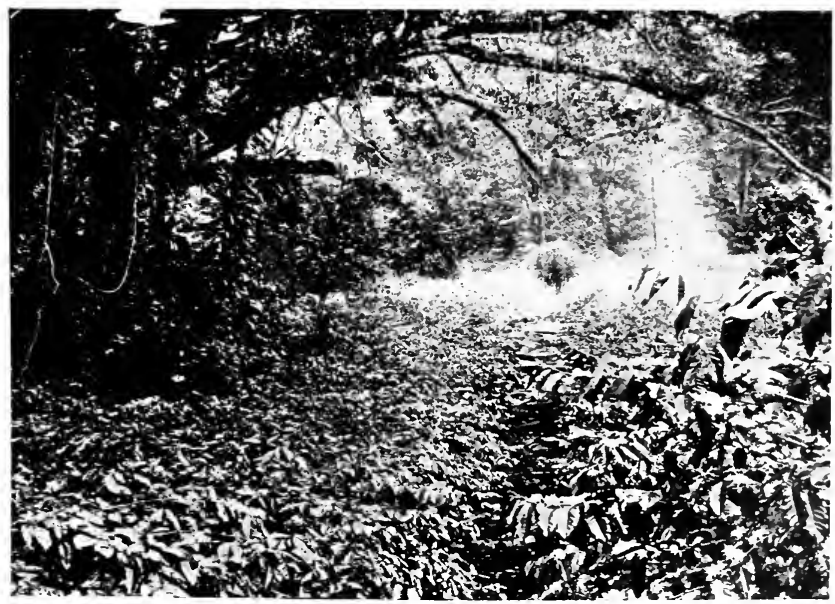

COFFEE IN FLOWER 


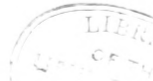


British youth to emigrate to these islands at present. Business is certainly not on the up-grade. The murderous Australian duties, imposed at the cry of the "White Australia" party (I did mention them before, good reader, and I shall mention them yet again), have ruined many, and are only too likely to hand over a number of new citizens to France, in the course of the next few years, if naturalisation continues to be made as easy and profitable as it is at present. Tenure of land is not too certain; tenure of life no better. The waste lands made available for use by the gradual lessening of the native population cannot be touched, since the New Hebridean will have none of the white man if he can help it. The island fever-a bad form of malaria -is a considerable handicap, though it could be much reduced by proper precautions, and by an antimosquito campaign similar to that at present being carried out in West Africa. On the whole, settlers must be recommended to keep away, until something further has been done about the vexed matter of ownership. When that is once settled, one can honestly advise enterprising young Britons to secure whatever may be available of the rich island lands. If not developed by the purchaser, they will at least sell again at a profit later on.

English travellers, on the other hand, if they are of the right kind, may be assured that they will find nuch enjoyment in a New Hebridean tour. I do not assert that nervous maiden aunts, or stout old gentlemen devoted to their dinners and their clubs, would enjoy the somewhat lawless atmosphere of the New Hebridean group-its "plentiful lack" of roads, its occasional shortage of fresh food, its fevers, lonely places, and unfriendly natives. But those who do not mind undergoing some discomfort and risk, for 
the sake of marvellous scenery, many adventures, and some of the strangest sights in the whole world, will do well to try these islands when they are tired of the Congo and the Amazon, and big game shooting in the Rocky Mountains. And let them not believe the people who assure them that they cannot and must not "stop over," or go inland, for they certainly should and can do both of these things.

Since the above was written, certain changes have taken place in the administration of the islands. It would be too much to say that they are entirely peaceful and safe, or that order is satisfactorily established, but much has been done toward both ends. The liquor traffic among the natives has been practically suppressed by the summary action of the British and French men-ofwar, who have stopped and overhauled every vessel carrying supplies of spirits, and confiscated the cargo. The uncontrolled shooting among the natives has received a strong check by timely displays of force. In Tanna, ' where tribal fighting was worst, peace has been practically established for the first time in the memory of living men. Disarmament is proceeding rapidly all over the group, through the systematic confiscation of all gunpowder and cartridges imported by either English or French, the native weapons being thus rendered useless to their owners. In all these matters, English and French have worked successfully together, and feelings of rivalry appear, for the time, to have passed away.

At present (April, 1907) the administration of the group stands on a somewhat uncertain footing. The Commissioners, English and French, have no clearly defined position, and not much power. The signing of the Convention, however, and the agreement to a joint Protectorate, have handed over the nominal respon- 
sibility for order to the civil arm, so that the rough and ready (and usually most effective) justice of the men-of-war will not in future play any very notable part in the pacification of the islands. It is obvious that one of two things is necessary for future peace-more lawmaking and law-enforcing powers for the civil authority, or a freer hand for the warships. At the moment there is some cause to fear slipping back. Illegal recruiting in especial, which has been a trouble in the group, but which, for the time at any rate, has been effectively checked by the vigorous action of the naval authorities, is likely to create further difficulties in the future unless a strong hold is kept upon the offenders.

Nothing in the history of the New Hebrides is more striking or in its way more instructive than the tale of the breaking-in of Tanna. It took place in a single day of October, r 9o6, a year after my own visit. The natives, who had systematically disregarded the threats and warnings sent them from time to time, and continued their tribal fighting regardless of risk to the whites, awakened one morning to find H. M. S. Pegasus lying off the east side of the island, and the French warship Vaucluse keeping guard on the west. In helpless terror, and certain that their last day had come, they sent messengers down to the mission-house to discover what hope remained. They were told that a meeting of the chiefs was desired on the mission ground that day, and that if they valued their lives they would come. A crowd of some fifteen hundred people, including six hundred armed men, answered the invitation, and sat or stood in rows on the rising ground of the mission enclosure, to hear what their fate might be. The British leader, Commander D'Oyly, addressed the crowd through an 
interpreter, and told them that it was the will of the two great nations that tribal fighting should cease. The island was surrounded, and no mercy would be shown to the people if they did not enter into an agreement to keep the peace. In reply, a Tanna warrior begged to know whether the British chief was "speaking strong." They had heard that kind of thing before, he intimated, but nothing came of it. It was explained to him that as Malekula had been served, so would Tanna be treated unless the required submission was made. The illustration was pointed enough, and the chiefs came in and swore to end the fighting-only too eager to make it clear that they gave in as fully and freely as possible. Since then there has been peace in Tanna. Many chiefs who had never seen each other's faces have met and even become friendly, though but a little while ago they were stalking each other's tribes in ambush and in the dark, murder their only thought. If the present state of affairs proves lasting, Tanna will be fit for settlement in the near future-and it will repay it.

Regarding the much discussed Convention, it has now become known that the hurried signing of the agreement was necessitated by the unexpected intervention of a third Power, which was discovered to be making large purchases of land in the group, with the view of acquiring a controlling interest. This made immediate action inevitable. None the less, it is to be regretted that matters had to be hurried through in such a manner that the vital questions of interest in the different islands, possible exchange, etc., could not receive consideration. No real progress will be possible until a definite conclusion on these points has been arrived at. 


\section{CHAPTER $\mathrm{X}$}

\section{MALEKULA-AN UNCANNY PLACE}

Bound for Sou'-West Bay-The Wandering Steamer-The Marriage Market in Malekula-An Avenue of IdolsThe Unknown Country-A Stronghold of SavageryTen Stick Island

A FTER a few weeks the steamer came in, and my A experience of plantation life ended. I was bound now for Sou'-West Bay, in Malekula, but it was not so easy to reach that spot as the local maps led one to suppose. From letters written at the time, the following extract is taken.

"It was 65 miles, as the crow flies, to Sou'-West Bay. The steamer, being neither a crow nor an eagle as to speed, covered the distance between Saturday afternoon and Thursday morning of the next week. This is rather below her usual gait among the northern islands, but still good.

"Time does not exist north of Efaté; the ship strolls lazily about from store to mission-house, from planter's to trader's, like a society woman trying to kill the hours making calls. She stops as often as a suburban train, during the day, and at night sleeps the sleep of the lazy in a comfortable bay. Mrs. Missionary Smith has a new blouse and a packet of hairpins up from Sydney-the steamer stops and delivers them. Mr. Planter Jones wants the vessel to call and take his boots down to Australia for resoling-the vessel kindly does. Sumebody 
wants to give a dinner-party, and invites everyone on board to go-the steamer politely makes that spot her stopping-place for the night, and everyone is pleased. There is no limit to the company's obliging amiability.

"Like the mysterious something in the children's riddle, that went 'round the house, and round the house, without ever touching the house,' we went round about Epi, until it seemed as if the island had hypnotised the ship, and would not let her away. We called at nineteen hundred and seven ports on this island (I speak from memory only; it may have been one or two under-or over), looked in on Ambrym and Paama for a few minutes, and then began doing Malekula with the thoroughness of a Cook's tour. We were now in the country of the real heathen, but the stops were so short (we had 4,302 to make, I believe, that it was impossible to see anything. At every port of the 4,302, and at every other port on the trip, we took up, or landed, or had brought on to the boat to visit, at least one white Presbyterian mission baby.

"It rained Presbyterian babies throughout the whole tour. They lay on saloon sofas sucking bottles, they flopped on smoking-room seats chewing bananas, they toddled up and down perilous unprotected decks, and attempted to commit suicide over precipitous rails, and wiped their small hands on newly painted ventilators, and cleaned it off on officers' white and gold coats, and held noisy synods of their own in private cabins, with boxes of sweets representing the mission funds, and a loud diversity of opinion as to the proper application thereof. I like to be accurate, above everything, and therefore I do not care to estimate the probable infant Presbyterian population of the New Hebrides as over four or five thousand; but that 
<smiles>[CH]</smiles> 


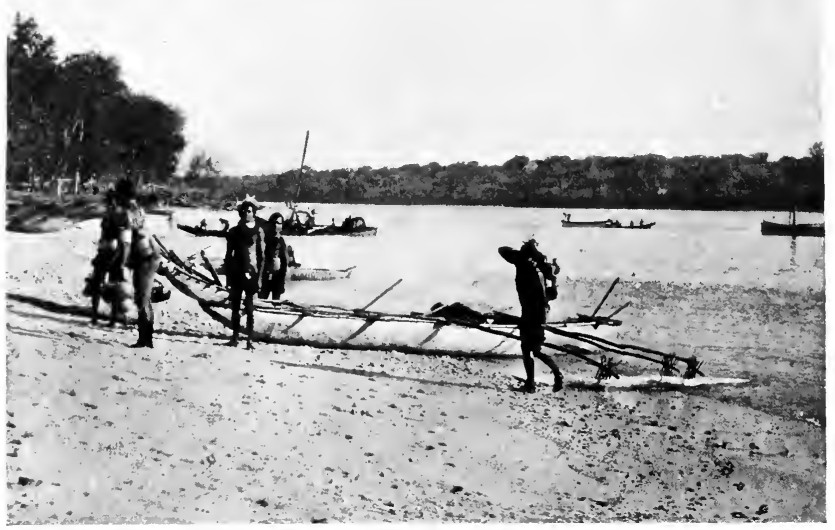

THE REFUGE ISLAND OF WALA-NATIVES COMING HOME TO SLEEP

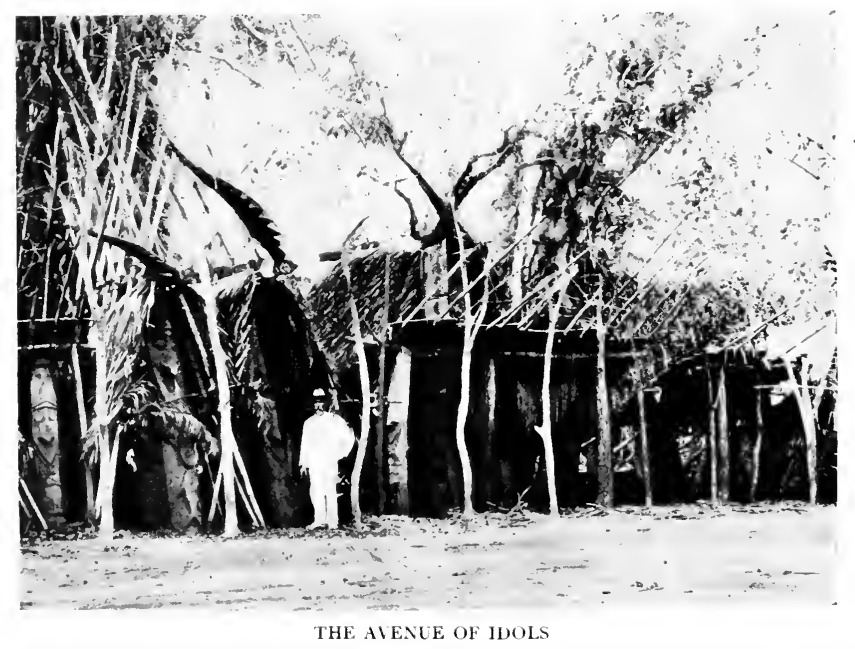


is certainly enough to pacify any possible doubts as to the supply of future missionaries, grown on the premises.

"On referring to the mission maps I find that the total number of mission stations in the group is only forty-five. There must be something wrong somewhere. I cannot pretend to disentangle it. The climate of the New Hebrides is notoriously destructive to the memory, and the thermometer as I write is fast

' reaching the point at which the capability to be exact melts out of the human mind. Before it quite reaches that figure I must make haste to state that things are as I said-more or less-that the Presbyterian baby is the principal product of the islands, copra and coffee coming a good way after; and that President Roosevelt, if he undertook a trip in the Tambo or the Malaita, would return to the United States even greener with envy than with sea-sickness.

"Dates disappear, and times melt away, within sound of the lazily whispering cocoa-palm. I do not know when we came to Wala, a strange little island off the coast of Malekula, where we stopped long enough to see several interesting sights. Enough that we did arrive there, and left again late at night, having been lucky enough to see what hardly any tourist has time, as a rule, to visit-the Sing-Sing ground.

"Wala is a tiny island, closely covered with thick bush. One can easily walk all round it in half an hour, and it lies only a few hundred yards from the mainland of the great island of Malekula, over thirty miles long. Yet five or six hundred natives sleep on Wala every night, spending the day on the mainland attending to their yam plantations, or pigeon shooting, and coming home about four o'clock in a huge fleet 
of canoes, every canoe loaded with yams and other food, and decorated with a rifle set up in the bow.

"The Malekulan never stirs abroad without his rifle-sometimes an old army Snider, occasionally a new magazine rifle of excellent pattern, costing a good many pounds. $\mathrm{He}$ is always more or less at war, after the New Hebridean fashion, which is murder, plain and plump. No one is ever supposed to die a natural death; poison or witchcraft is always assumed to be the cause of decease when a man passes away from sickness of any kind, and such a death demands revenge just as loudly as an actual shooting. So it comes about that the whole of Malekula is engaged in carrying out one enormous 'vendetta' - all by means of treachery and ambush. Every Malekula man goes in constant fear of his life; if he has not shot anyone lately, or fallen under suspicion of charming somebody's life away, there are sure to be a dozen or two such injuries scored up against his village in general, and one man's death is as good as another, provided he belongs to the obnoxious tribe.

"For this reason the Wala men seek safety from the fierce bush tribes of the interior by sleeping on this little fortress isle, that lies safely out from land. The neighbouring island of Rano is unfriendly, and always picking off stray Wala men when the canoes meet at sea; but that is better than running the gauntlet of thousands of fierce bushmen, or so the Wala men think.

"Most of the islanders were away when I landed on Wala, and went for a sight-seeing walk, under the guidance of a passenger. A few men who had come home early wandered about the shore, wearing the national dress of Malekula, which consists of a cartridge belt of woven pandanus fibre, drawn tightly round 
the waist, a boar's tusk suspended round the neck, and a pig's tail in each ear. One man, with his five wives, was just coming up from his canoe, the women carrying heavy loads of yams and babies. They wore a small sash round the middle, and a few beads, trade and native. The man was evidently a noble. Only a Malekulan lord can afford several young, attractive wives, for a wife costs from ten to twenty-five pigs (pigs being the recognised currency), and it is the possession of pigs that fixes a man's rank in the aristocracy of the country. To become noble a man has only one thing to do-kill pigs and give feasts. Eight or ten pigs thus sacrificed will give him the lowest rank; a hundred will make him something like a duke.

Anything equivalent existing among the heathens of London, or possibly the wild tribes of Sydney? Of course not. . . . These tropical climates plant strange fancies in the brain.

"This system of coinage creates a curious difficulty, the like of which I have certainly never heard in any civilised country-at least, I think not. A man is generally old and ugly before he has amassed a large number of pigs, and so acquired command of the wife market. He picks himself out the youngest and nicest-looking wives, consequently the most expensive, and buys them. That is all right. But then starts up some fine young fighting man, with hardly a porker to his name, and the expensive twenty-pig wife takes a fancy to him, and runs away to the bush with him, and everybody laughs at the old Crœsus, and calls him a fool. Truly, an extraordinary state of affairs, causing the Christian traveller to lift up pious hands of thanksgiving for the benefits enjoyed by his own race, among whom such sinful absurdities are unheard of. 
"The New Hebridean wife is very hard-worked, and not too kindly treated, but she has one source of satisfaction. as a rule-the price that was paid for her.

“" I cost twelve pigs,' Mrs. Frizzyhead No. I boasts to Mrs. Frizzyhead No. 4, who is a new acquisition, and inclined to be cheeky. No. 4, who is painting her forehead jet black with burnt cocoanut, and drawing a line of red ochre down her nose, pauses in her toilet to say contemptuously, 'I cost fifteen!'

"Mrs. Flatface, the sole joy of old Mr. Flatface, from the bush, here chips in:

" ' I cost twenty, and two of them were big, as big as a whaleboat from the steamer!'

"The Frizzyhead ladies subside, and wait till they can catch young Mrs. Blackleg coming up from the yam plantations, with a baby in her arms and a hundredweight of yams on her back, to revenge themselves by telling her that she only cost ten pigs, and is a low creature anyhow.

"We pass the 'hamal' by-and-by-a large, ornate reed house, with a high gable roof, an extremely small door, and no windows-where the men sleep and live by themselves, when they feel so inclined. It is surrounded by a high stone wall, and is strictly 'taboo' for all females. It seems to be a kind of dim prototype of the civilised club, and is evidently very popular among the men, for when they are at home there are always a few lounging about the enclosure, or peering out of the door.

"Did I get over the wall, and stand where no female foot had ever stood before? No-although I was sorely tempted to do so-for my companions were so much against the idea that I had to wait for a future 
chance. I photographed the place instead, and went on to the Sing-Sing ground.

"This was the strangest and most uncanny place ever conceived outside of a nightmare-a bare, gloomy alley, about a hundred yards in length, shadowed by dark, overhanging trees, and faintly lit by stray gleams of the declining sun. Along one side ran a perfect graveyard of small, rough tombstones, or what looked like them. These were altars for sacrificing pigs-and other things. It is not very often, nowadays, that the other things are available; still, the resident missionary found it necessary to interfere only the other day, and use all the influence he possessed to prevent the holding of a projected cannibal feast; and there is reason to believe that not a few natives have been eaten here of late years, strictly on the quiet.

"Opposite the stone altars, looking indescribably weird and evil in the red rays of the declining sun, stood a long range of drum-idols, carved out of hollow tree-trunks. They were of all heights, from two or three feet up to thirty; they all had black, skull-like, empty eyes, and wicked grins; their faces were carved into ghastly wrinkles, and many of them had long tongues hanging derisively out of their mouths. The crowning horror was the strange black bird, or bat, placed upon the head of nearly every one. These birds were very fairly carved, and as big as albatrosses; dead-black in colour, with a few narrow white lines on the wings. Hovering grimly above the uncanny idol-faces, their beaks bent down, their gloomy wings outspread, they seemed the very spirit of Nightmare itself.

"All the idols were hollow, with deep clefts in their sides, so that they would give out a heavy, booming 
noise when beaten. They were supposed to represent the departed ancestors of the natives; and the nightmare birds, perched high up on the idols' heads, figured, most fittingly, the dark spirits of those who were thus commemorated.

"In the vacant space before the idol-drums the natives hold their dances, at certain times of the year, and also their feasts. Almost at any time the mocking faces of the idols may laugh cruel scorn, and their drum bodies thunder wild rejoicing, over the dying agonies of men slaughtered for cannibal feasts on the rough stone altars that border the Sing-Sing ground. All Malekula is determinedly cannibal, although the influence of the various mission stations about the coasts has caused the apparent suppression of man-eating in places where the white people might actually see it. All the bush villages are known to indulge in cannibal feasting every now and then, and-'not once or twice, in this rough island story'-a white man has furnished the filling for the cooking-pot.

"What goes on in the farther interior no one knows, for no white man has ever been to see; but from the reports of the natives it seems evident that man-eating is so common as to terrify the milder cannibals of the coastal districts from ever venturing across the wider parts of the island.

"There was yet another strange thing to see before we left Wala-the collections of boars tusks belonging to the chiefs. These were displayed on a long stand, that exactly resembled eight or ten bazaar stalls joined together. There were some hundreds of them, placed in long rows-how many exactly I had not time to count, as I heard that the canoes were just coming home from the mainland, and I wanted to be on the 


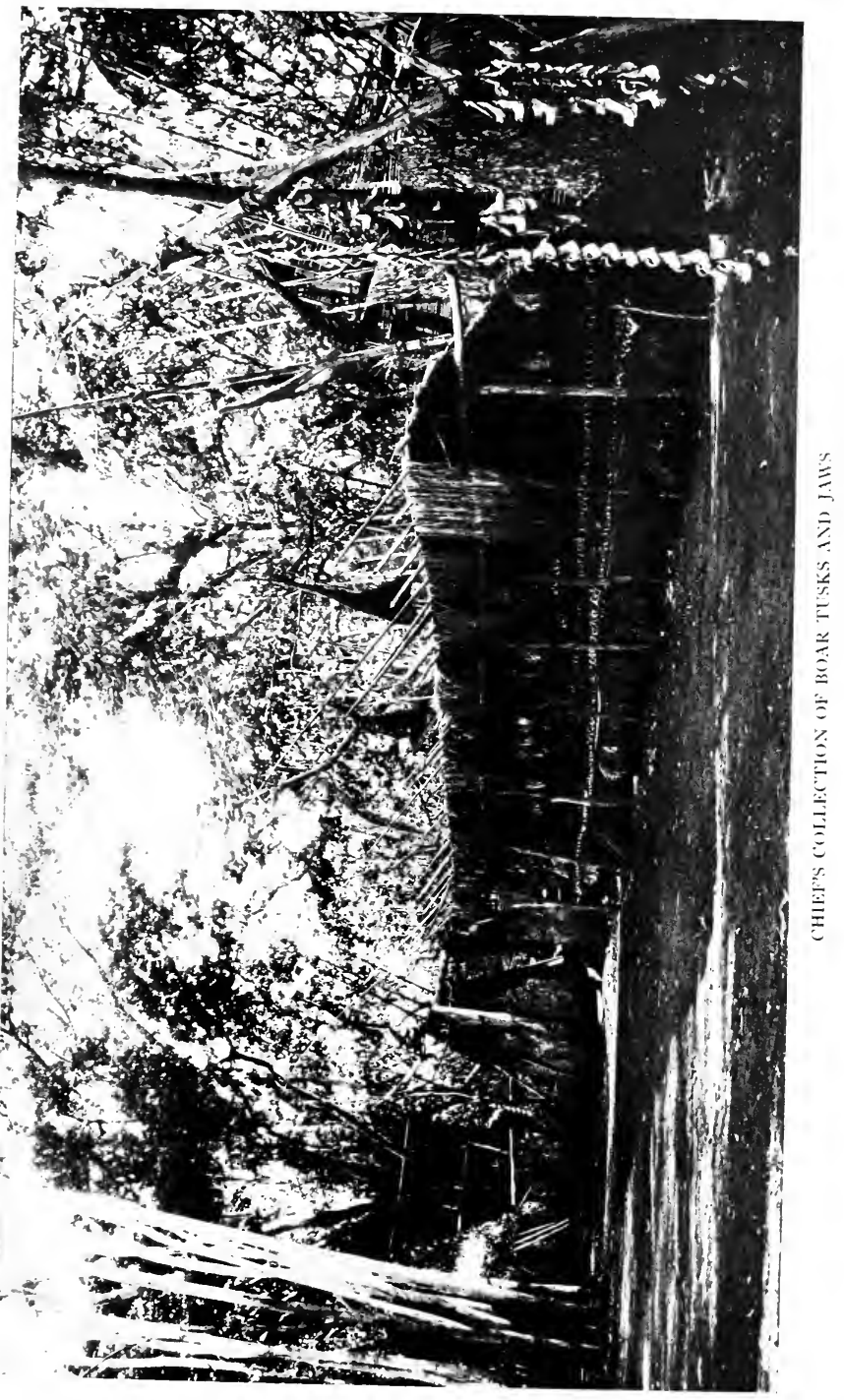




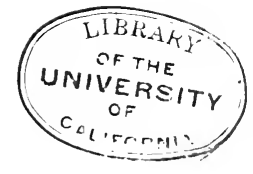


shore to meet them. Many of the tusks were curved into a complete double circle. These are greatly prized, but are only obtained at the cost of much suffering to the unlucky pig that furnishes them. $\mathrm{He}$ is tied up in a house, and never allowed to wander forth, for fear of destroying his tusks. From each side of the jaw the teeth that oppose the tusk and prevent its going too far are removed, so that in time it grows right round through the unlucky animal's flesh, and provides a splendid double armlet for the native who owns the pig.

“There were also several large bouquets of pigs' jaws, neatly tied together, hanging up on the stall. These were patents of nobility, representing so many pigs killed and feasts given, in order to attain chief rank.

"On the burning white shore, as I came out of the bush, the canoes were beginning to come up in scores, returning from the day's work on Malekula mainland. The Wala people decorate their canoes with some taste, a good deal of carving being seen. They are also great builders of war canoes. One or two of these lay on the shore as I came down on my way to the steamer. They seemed large enough to hold fifty or sixty men, and were partly dug out, partly built up, the upper pieces being neatly laced and tied together. These great canoes, however, are very seldon used."

Sou'-West Bay, another part of Malekula, to which I was now bound, is a place of an evil reputation. Murders of the whites have always been frequent here, and the last was not many months old when I landed. The steamer put in for half an hour to take up copra, and land cargo. She seldom stops longer, and her calls are somewhat irregular.

The place, as I saw it first, seemed to match in its 
appearance its odd seafaring name and wicked reputation. A wide stretch of water, with little shelter; ominous overhanging cliffs and rocks; a beach of black volcanic sand, torn by thunderous rollers. On the shore, assembled, the whole white population of the district-the Presbyterian missionary and his wife, one married and one unmarried trader, and a French missionary priest. This was Sou'-West Bay.

A few natives were hovering about the trees near the beach-creatures of appalling ugliness and evil, carrying a loaded gun apiece, and absolutely naked save for a cartridge belt. There was nothing to be feared from them, however. Sinister as is the history of Sou'-West Bay, I understood the New Hebridean well enough by this time to be quite certain that open daylight attack, with a steamer in the offing, was the last form of sport likely to attract him.

I had trusted to the hospitality of the islands in making a stop here, and I was not mistaken. The Presbyterian missionary at once invited me to stay with himself and his wife as long as I liked, and I and my baggage were swept off to the neat little house above the beach where the Rev. Mr. B- has his home. The steamer was away again almost immediately, and only a trail of black smoke on the far horizon marked the disappearance of our last link with civilisation.

Of this, one of the most interesting spots in the whole New Hebridean group, the travelling world, so far, knows nothing at all. When a stray wanderer does by any chance drift up in the Sydney boat, he has neither time nor, apparently, desire to take even a walk about the bay. Perhaps it is as well, however, that the time-tables do not allow of any exploration, for the Malekulans of this part are not company for 
everyone, being impulsive by nature, and apt to commit breaches of manners which, no doubt, they are the first to regret in cooler moments-after the bones are picked, and when the smoke of a man-of-war coming to tea and talk with them becomes visible over the cottonwood tree-tops.

Malekula, or Mallicollo, as it is commonly called in the geographies, is the unknown country of the New Hebrides. Though only about sixty miles by thirtyfive, it is still for the most part unexplored, and the white settlers and missionaries, of whom there are only a few, all have their dwellings round the coastline, or on the outlying islets-as at Wala. For a very few miles inland, something of the country is known, and the island has twice been crossed at the narrower ends. But the great tract lying in the interior is still untouched. What may be there, nobody knows, although half a century has passed since the first settlements of missionaries and traders on the shores. There are all kinds of wild traditions current, as is generally the case where unknown lands are in question. It is said by the natives of the beach districts that a tribe of pigmies inhabits the interior; and this has apparently some evidence to support it, since one of the medical missionaries assured me that he had himself seen a man from the interior who was only four feet six. It sounds like further proof, when one is told that the coast tribes declare these pigmies are extremely vicious and hostile, and that they are expert in the use of poisoned arrows-these being well-known characteristics of dwarf races, as observed in other lands.

There is at all events no doubt as to the character of the forest tribes as a whole, since they furnish quite sufficient proof of it from time to time, in their sudden 
descents to the coast, where they burn, slay, and destroy wholesale, retreating again to their mountain strongholds unpursued and unpunished, for the most part. They hold the tribes of the coast in constant terror, and no money would procure a guide into the interior, even with an armed force to guard him.

This is one of the reasons why the island is still virgin ground to the explorer. But there are others. It seems at first sight that an island which looks on the map as if it could be crossed in two days' march should not remain long unknown. One very good reason, however, lies in the fact that, commercially, it would pay nobody to go. There is practically no land in Malekula worth having. The country is known to be hilly, broken, and irregular in the highest degree, cut up by mountain ranges rising to four or five thousand feet, and covered with the densest forest. No one wants the interior. That is a second reason.

Another lies in the fact that the scientific explorer is barred off by the question of expense. An armed force would be a necessity to any expedition, and it would richly earn its pay. Some losses would be certain. Fever could not be escaped; the hostile tribes would fight hard, and poisoned arrows silently sent out from the bush, or poisoned spearheads cunningly concealed in the pathway, just where they would be most likely to pierce an intruding foot, would certainly account for not a few of the travellers. For this reason, a force out of all proportion to the apparent need of such an expedition would have to be taken, fed, and paid. Progress, also, would be extremely slow, and here expense comes in again. So far as anyone has penetrated, the country is so exceedingly irregular, precipitous, and densely wooded, that only a few miles a day would be 
covered at best. When the crews of the French and English warships, Pegasus and Mcurthe, marched eleven miles inland, and back again, in a day and a night of October, I905 (much the most important journey into the interior that has yet been made), the exertion was so great that several of the men fell out from sheer exhaustion, before the first half was done. It may be judged how much ground an ordinary expedition would be likely to cover in a day, since this is the very best that a body of trained, picked, and powerful man-of-war's men could do, carrying only bare necessaries for the march.

The tribes of the interior have, in many cases, never been down to the coast, or seen a white man's face, but they have nearly all managed to obtain rifles, and where these are missing, poisoned arrows supply their place. They are quite determined to allow no invasion of their country, either by white people or natives from the shore. The attitude which they maintain has a decided influence over the natives of the other islands, and the murders and massacres of white people which the Malekulans have successfully carried out from time to time, have had a bad effect over the whole group. For this reason, Malekula is one of the first places to which any established government would turn its attention, if the islands were annexed. Something has already been done by the French and English warships, acting together; but the place cannot be thoroughly taken in hand, under existing circumstances, and in consequence remains exactly what it was in the days of De Bougainville and Cook - a hell upon earth of cannibalism, murder, and infamy unspeakable. For be it known that the truth, or half the truth, about the lives of these savages 
can never be told. Any book which depicted them all in all as they are would be fit for nothing but to be burned at the hands of the common hangman. Darker spots upon the surface of the earth than Malekula there cannot be; worse fiends in hell or out of it than most of the natives not the wildest imaginations of madhouses could picture. And there description must cease.

About the little mission-house in Sou'-West Bay, heathenism and cannibalism surge like tides of a stormy sea breaking upon a solitary islet. It is small wonder that the Presbyterian mission and the Catholic alike, one many years old, the other comparatively new, have been able to do very little. The representatives of both churches have had the narrowest possible escapes for their lives from time to time; and things have been so bad for the traders that a man-of-war called in 1904 with the object of taking them safely away, should they so wish. One accepted the offer, the others remained where they were, and simply "chanced" it until things quieted down.

In Sou'-West Bay, close to the entrance, lies the only piece of land in the group that belongs to Great Britaina small wooded islet of considerable height, only a few hundred yards in circumference. The story of its acquisition is an amusing one. Sou'-West Bay has always been considered the best place in the islands for target practice, by the man-of-war patrolling the group, and this small islet was used as a target so frequently that it seemed in danger of being gradually shot away.

The chief who owned it protested, and wanted compensation. The captain of the man-of-war, who understood New Hebridean nature, knew that these 


\section{MALEKULA-AN UNCANNY PLACE I9I}

claims would be a ceaseless source of blackmail unless they were settled once for all; so he bought the island outright for the British Crown, paying ten sticks of tobacco for it, and everyone was satisfied. The place, since then, has always been known as "Ten Stick Island." 



\section{CHAPTER XI}

\section{MALEKULA-THE OUTER MAN}

How Bilyas made itself Strong-The Slanghtered TradersInto the Unknown Country-The Cannibal ToiletNew Fashions in Murder-The Ignorant White Woman

$7 \mathrm{HE}$ mission-house stands in the middle of a clearing; 1 behind it, wave after wave, rise the unconquered heights of the mysterious forest land, clothed in densest green. One burnt and barren spot, some two miles above the settlement, marks the former site of Bilyas, one of the very worst of the villages near the coast, which had been destroyed by the British and French warships, Pegasus and Meurthe, three months before my visit. The story-one of a good many similar tales relating to Sou'-West Bay-may be given as an example of the rest.

About August 1904, the men of Bilyas, a hill fortress notorious for giving trouble, declared their intention of "making themselves strong." This expression, in the mouth of a Malekulan native or tribe, is best translated as a wish for self-advertisement-a desire to be widely talked of. It is on such occasions as this that the white people are really in danger, for the murder of a white man or woman is considered a plucky and creditable performance among the tribes, and is likely, on that account, to be selected as a means of securing the desired advertisement. 
In this case, the Bilyas men, who apparently wanted to do the thing thoroughly when they began, openly declared their intention of killing the crew of the first recruiting schooner that should come into the bay. Very shortly afterward, a French vessel appeared, and sent out her boats. The Bilyas men were rather disappointed to find that the Frenchmen-thinking it was "better to be a coward for half an hour, than a corpse for all your life" - had stayed on board the ship themselves, and sent out the boats manned only by natives from another island. However, they resolved, at least, to make a "bag" of the latter. Now, it is not so easy as it might seem to entrap and murder the crew of a recruiting boat, for they always work in pairs, one carrying out the negotiations on the beach, the other remaining some distance off, and keeping the natives on the shore covered with their rifles, for fear of treachery. The recruiting boat itself is usually, though not always, armed as well. The Bilyas men, however, were famed even among the Malekulans for their high degree of accomplishment in the fine art of treacherous murder, and they proved themselves equal to the occasion. They greeted the recruiters most civilly, and told them there were several men who were willing to engage. There was a little polite conversation, and then the men of Bilyas began discussing the bonuses that were to be given to the relatives of the enlisters, according to custom. They asked for guns, and demanded to see all the rifles that were in the boat, throwing open the breech of each one, apparently to examine it, but really to see if it was loaded. Now the native crew had very foolishly trusted to the covering boat, and brought no loaded firearms themselves, so a11 the rifles were empty. This was good, so far. 
"Send away that other boat of yours; we are afraid while they cover us with their guns," said the plotters, acting under the orders of a cunning old chief who was leading the party. The boatmen, misled by the friendly tone, signalled to the boat to draw away.

It seems that after this, their hearts began suddenly to fail them, for though they spoke no word, the old chief read their faces, and said in the Bilyas dialect to his followers: "Be quick, for these men are beginning to fear us." He spoke with a smiling face, and held the boatmen in conversation, using their own tongue, while the Bilyas men closed in.

"They are thinking of going," warned the old chief, still smiling, as he watched the faces in the boatfaces now paling fast under the shadow of a fear that was clutching at every heart. . . . "Now!" he cried, dropping all disguise-and the men of Bilyas fired. Three of the wretched victims dropped dead; one fell dying; the rest escaped out to sea. . . . So Bilyas "made itself strong."

A week or two later the Meurthe came in, burned a couple of villages (the inhabitants having fled into the bush), and steamed away again. In July of the next year-1905-she returned, sent an armed expedition up into Bilyas itself, and killed four natives. A French sailor, however, was killed also, and, owing to some confusion about prisoners, the force retreated in some disorder, leaving things on the whole much worse than they were before.

As there were two or three outstanding murders of white traders to avenge (the cases of Sarguey, Gardemer, and others), the British and French now took the matter up together, and on September 3 rd, about three weeks before my visit, the Pegasus and the 
Meurthe sent a combined expedition inland, under the leadership of Commander H. D'Oyly, of the Pegasus. This force was not intended to take life, unless in selfdefence, but merely to warn the natives, and clear out a hornet's nest that had long given trouble to the whole bay. The work was done very thoroughly, the town and all its contents burned, and the power of Bilyas thoroughly broken. None of the actual murderers were captured, either then or at any other time. The real offender never is captured in such cases, but the common (and very effective) course of justice followed by British warships is to make things so hot in general for the criminal's tribe, that it is discouraged from any other attempts at cheap advertisement for some time to come.

The murder of the Frenchman Sarguey took place in April 1904, and was not unlike the other. In this case, there was no one who wanted to "make himself strong"- - only a desire to secure goods without paying for them. Sarguey had gone up in his cutter a little beyond the bay to a spot called Lumbumbu, to buy yams and pigs from the natives, who happened to have a superfluity of both, and were willing to trade. They were quite friendly to him, and when he took his pretty white-sailed cutter up into the bay below the village, and ran his dingy ashore into the midst of the crowd collected to see him land, everything seemed as fair and promising as the brilliant day and the lovely island itself. But when the men of Lumbumbu saw the boat all full of trade goods, they grew very covetous, and began planning among themselves how to secure all these riches without parting with their own goods. Sarguey had two loaded rifles in the boat, carried as men carry firearms all over the New Hebrides- "in 
case" - and the men saw that these must be got out of the way. So they told the Frenchman that one of them would go away with him in his cutter, as he had got into trouble, and wanted to recruit for the plantations; and the Frenchman could take him anywhere he liked. This meant a profit of several pounds, so: "All right," said the trader cheerfully, "I'll take you, my man; jump in."

"But my family-you know I must have a rifle for my family, or thev won't let me go," objected the recruit anxiously.

"Well, I'm not out recruiting, you see, and I haven't got any trade rifles with me," said Sarguey. "I'11 send them one later."

"That would never do; I'll have one now, or I won't go," declared the man sulkily. "Give me those you have in the boat, to look at; perhaps they're good enough. But I won't go if they are not."

Now a recruiter can get ten pounds for a good man down at the plantations, if hands are scarce, and the rifles were not worth two pounds apiece. Sarguey turned to hand them over for examination.

“. . . Master, take care!" warned one of his own boatmen; "I think they mean treachery!"

It was too late. The rifles were scarcely out of the boat before the whole pack fell upon the Frenchman like wolves. One shot him in the back, another clubbed him on the head, and the rest began to loot the boat, with horrid yells of joy. The native boatmen, terrified out of their lives, swam off to the cutter, and took refuge there. They were not followed; so, after the murderers had gone their way, and left the bloodbespattered body of Sarguey on the shore, the frightened crew ventured back to the lonely beach, and brought 
their master out to his ship. He was still breathing when they found him. The rest of the story was told as follows to the mission folk, in the pigeon English that serves as a connecting-link among the Babel dialects of Malekula:

"Head belong him, he break plenty. He tell me takeum cutter big-fellow hospital, Ambrym. We tell: 'What name (why?) we go Ambrym, you no good, you dead.' He tell: 'No, all right.' By-n'-by he speak wantum one-fellow water, two-fellow water; we give. No wantum more. By-n'-by he go finish (died)."

However, the Sou'-West Bay people, though treacherous and cannibal, are not in the habit of killing white people "on sight." They may kill you, as they killed Sarguey and others, if they see their way to a clear profit by your death, or they may use you as a means of advertisement as explained above-or they may put an end to you by a sly bullet from the bush, if they have taken a dislike to you, and think that your presence is bringing down bad luck on the crops. But, if they have no personal objection to you on the whole, and they do not suppose you have been using spells to call down a curse on the country, and no native has happened to die a few weeks after you misguidedly gave him five grains of quinine for fever-why, then, being suitably introduced, you can beard the Malekulan in his mountain den, if you feel inclined, and come off none the worse.

This was, at all events, the opinion of my kind host of Sou'-West Bay, who, hearing that I was anxious to get a peep, if possible, at some of the mysterious bush towns, offered to escort me up to one that he had never visited himself, and that was entirely unknown to any white person. It was about six miles 


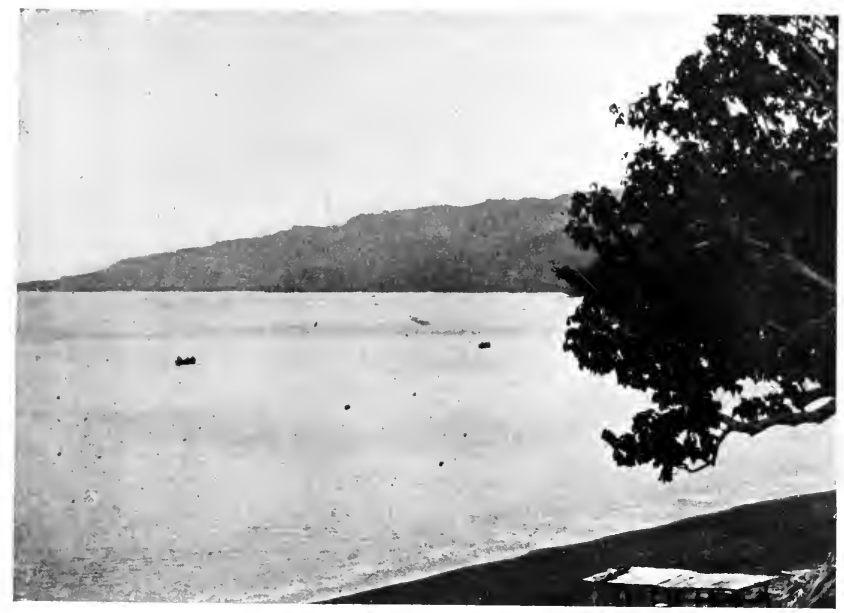

AFRAID TO LAND-SOU'-WEST BAY

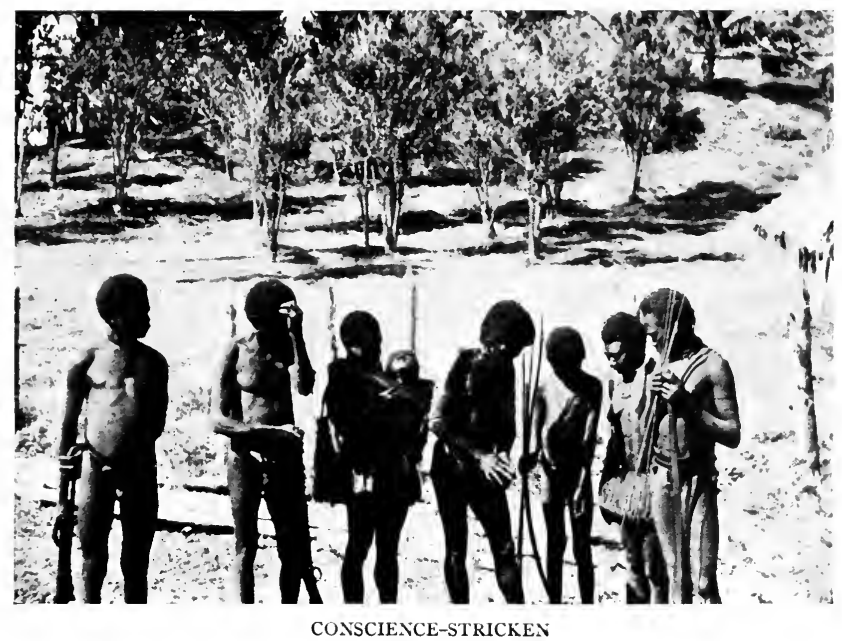




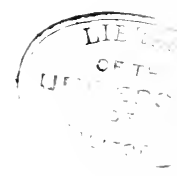


inland, in the real fighting country, and it certainly could not have been reached by the man-of-war's people, had they been there, otherwise than with a strong force and a couple of Maxim guns. Mr. B-, however, thought that if he and I were to go up quite unarmed, and only accompanied by a couple of boys to find the way, and if we did nothing that might be likely to annoy the natives, there was every probability that our insignificance would protect us, so that we should not be molested in any way. An idol dance was to take place in this forest stronghold in a day or two, according to the rumours current about the beach, and Mr. B- was sure that it would be very well worth seeing.

I was quite sure that it would, also, and besides, who would not have jumped at the chance of such an exciting adventure? So we started off very merrily in the early morning, taking a couple of mission natives to find the track for us, and carry our food, and wearing the lightest of cotton clothing, and the shadiest of hats, to protect us from the raging sun.

We had some boating first, up a narrow winding arm of the sea, dotted with exquisite green islands-a very home of the fairies, lovely and silent enough to let one forget that its actual frequenters were hideously painted naked savages. Who was the first teller of "travellers' tales" to vilify the beautiful mangrove? Why does every wanderer slavishly repeat the old fables about its ugliness and gloom? Spreading a close rampart of glossy pale-green leafage, starred with small white flowers, above the china-blue water of the lagoonweaving quaint reed-work of interlaced black stems and roots, underneath the brave show of gloss and colour-shooting up here a single spire of leaf through 
the empty water, there a far-out little islet like a black basket full of bright leaves-the "horrible" mangrove and its "ghastly" foliage provided half the beauty of the lagoon. It is not a wholesome or a healthy thing to have about; but if one is to deny the beauty of anything that is dangerous or evil, one must rule out a large proportion of the loveliness of this perverse yet pleasant world.

By-and-by we landed, and then, leaving the fiord behind, we walked four miles farther inland, up toward the mountain town. Four miles! what is that to any healthy Briton? A mere stroll; a saunter scarcely deserving the name of a walk at all. Four miles of hard white English road, of bracing breezes. . . just an appetiser for dinner, no more.

But four miles in the New Hebrides is something else.

To begin with, there are no roads. There is usually a track, some few inches wide, but one cannot even keep it without a guide, and it is generally slippery and boggy, for the annual rainfall, in these islands of the blest, is reckoned by yards instead of inches. Then there is no level ground. Either you are struggling up the side of a slope so steep that you have to use your hands, or you are sliding with clenched feet and fingers down into a pit of destruction. The land seems to be composed entirely of gorge and gullies, and the track never appears to lead along them, always across. Also, there is little air, and not much light to speak of, because the overhanging canopy of densely knitted leaf and liana shuts off both. Then it is hota good deal hotter than the orchid-house at Kew, and a good deal moister, and before you have gone a mile, you are as wet with mere heat as if you had been dropped bodily into the sea. It is long odds, too, that you 
have a touch of fever hanging about you, and island fever takes all the stiffening out of your bones, and weights your brain with lead. . . . Four miles is four miles, to an unseasoned visitor, in the hot season; still more is eight miles eight. Some weeks later, I walked thirteen miles, over very bad country, and survived the feat; but more than that I never attempted while in the New Hebrides. It is only about some part of Efate, and in the interior of Tanna, that riding is possible. Elsewhere, almost all the travelling is done by boat, so as to reduce the inland scrambling to a minimum.

The scenery-it is an unpoetical comparison, but really I cannot help it-was almost exactly like a transformation piece in a pantomime. The enormous wild taro leaves, great green parasols with the rare sunlight dripping through, standing up on tall thick stalks higher than a man-the scaled and diamonded palmtrunks, the close-set banyan columns, garlanded with long drooping fringes of delicate creeper; the immense nameless roots and buttresses of giant trees, projecting themselves like the edges of "flats" upon the winding pathway - the bird's-nest ferns, pale orchids, and knotted lianas, perched aloft in the "flies"-all these needed only the usual troop of posturing nymphs to bring the very sound of the orchestra, and smell of gas and velvet and orange-peel up before one's senses.

Instead, just as the pathway opened out upon the most theatrical of "glades," we came upon a score or two of young Malekulans clothed, as usual, in their native impudence and a cartridge belt, and very busy indeed making up themselves and each other for the dance. One had just completed his head-a very neat arrangement in powdered white wood-ash, giving him 
an extraordinary resemblance to a negro barrister who had somehow omitted to put on his clothes. A rival had contrived to leave alternate stripes of his own black wool, and to fix on a large black rosette of close-felted vegetable fibre above the centre of his forehead. The forehead itself was painted shiny black with burned cocoanut. Another had used the same invaluable pigment to darken his eyebrows, and circle round his eyes, so that he presented a curiously theatrical appearance, only a little marred by the broad red stripe down his nose. Some had fastened plumes of cock's or parrot's feathers, glossy black or vivid green, into their woolly hair; others arranged scarlet flowers in it with some taste, and all were striped about the face with warlike vermilion paint in different patterns. A pig's tail in each ear was evidently the crowning touch of elegance, and boar's tusks, worn locket-wise upon the chest, seemed the height of the mode. Most of the men had charms done up in greasy little packets, hanging on a very dirty sinnet string round the neck, as a protection against murder. These, it may be noted, were carefully adjusted on the back, not on the breast, for a Malekulan always attacks in the rear. Small water-worn stones are the charms most commonly used.

All were armed with rifles, and if the ammunition of the rest was to be judged by some specimens I saw, every one was loaded for elephant at the least. As the largest indigenous animal in the islands is the fruit bat (excepting the wild boar, which is probably an introduction, and is not at all dangerous), it seems fairly obvious that the noblest of all animals was the game for which my friends were prepared.

There was nothing noble about themselves, however, 


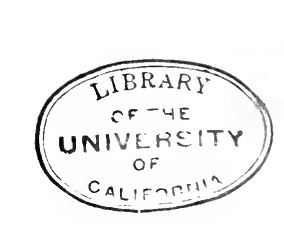




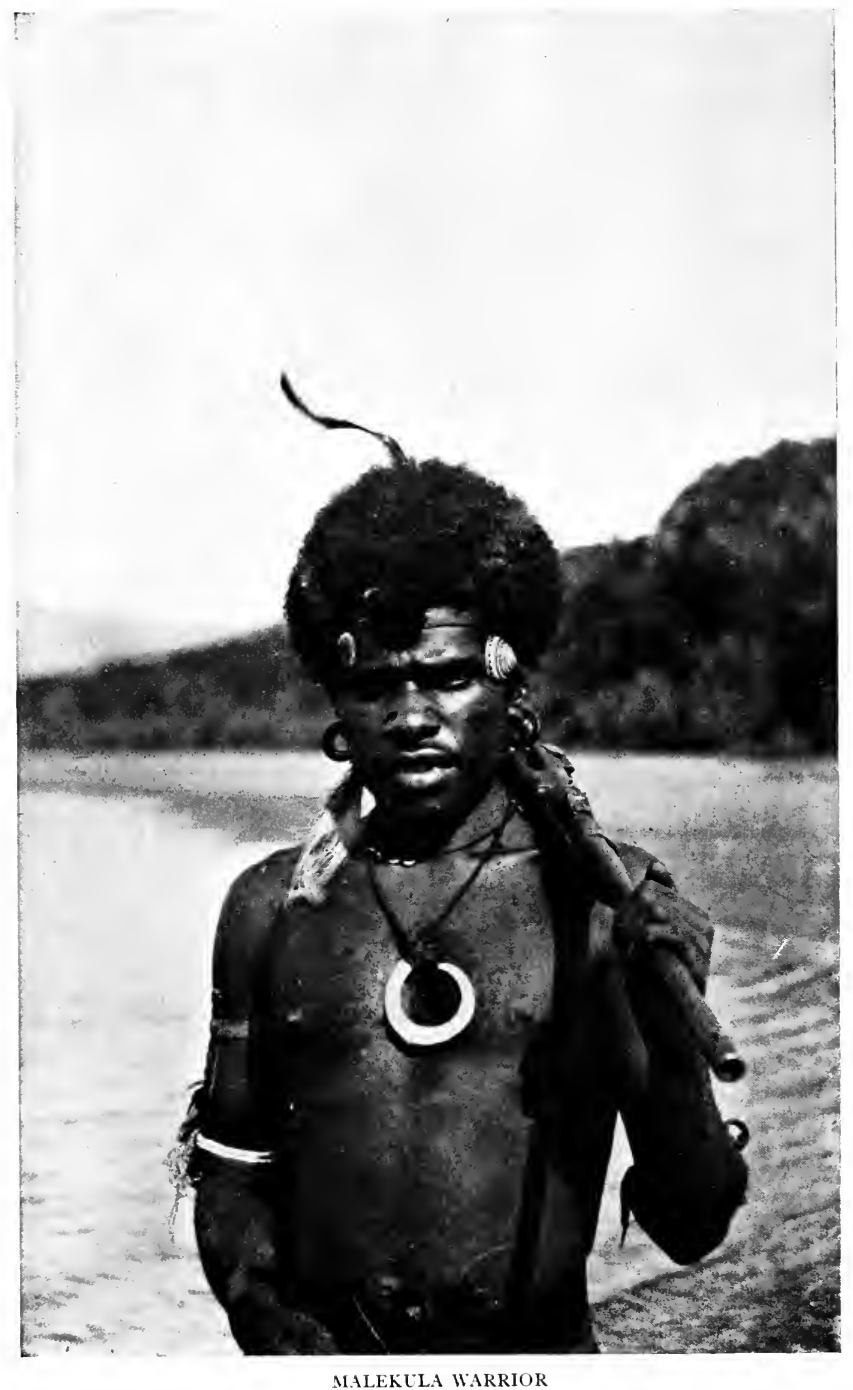


for a more ill-looking crew I had never seen. Nor does the Malekulan's expression belie his nature. As already suggested, he considers murder a fine art, and treachery the highest of accomplishments. Cannibalism he thinks a proof of a fine manly character, infanticideusually compassed by the simple method of throwing unwanted children into the forest to die, or burying them alive-is a recognised social custom. He trusts, and is trusted by, no one, for he walks in the continual fear of death, and with murder always lurking in his own heart. In truth, the "Shadow cloaked from head to feet" spreads, night and day, its gloomy wings over evil, beautiful, mysterious Malekula.

A new fashion in murder, by the way, had come in some time before my visit to Sou'-West Bay, and this was the manner of it. You contrived to get on friendly terms with your enemy, and began to talk to him. Your gun, of course, was held under your armpit as you talked, cocked and loaded as usual, because that is a thing that no gentleman would think of objecting to, when your arms were held harmlessly down by your sides. And while you talked, discussing the last pig-killing, and the yam crop, and the likelihood of a hurricane, you kept carelessly shifting the gun about under your armpit, till it was at the proper angle to cover your enemy's heart. So, while you still talked pleasantly, and still kept your innocent hands well in view, another native diplomat, acting as your confederate, slipped up behind you and pulled the trigger. . . Very neat-and very Malekulan.

These warriors interested me greatly, by reason of their demeanour, which presented quite a novelty in my experiences of island travel. Some of them had probably been "recruited" for labour in other parts of 
the group, and must have seen white women; but many certainly had not. Now, about out-of-the-way places in the Eastern and Southern Pacific, the sight of a stranger, especially a woman, creates almost as much excitement as a flying-machine would do. Crowds follow the visitor, and the liveliest and minutest curiosity is expressed about all his or her belongings, peculiarities, and manners. Life, indeed, for the time being, is lived under a social microscope, and every word or action is noted with the deepest interest.

Not so with my friends the Malekulan fighting men, in the gloom of the dark-green forest. From a safe distance, they regarded us with a sort of sullen curiosity, not unmingled with fear. They did not smile; they did not approach to question our native boys. They stood or squatted in groups, leaning on their guns, and watching us uneasily under their lowering brows.

The missionary and I were hungry now, and we sat down and ate, while the Malekulans, waiting for other parties to join them, stood in the shade of the darkest trees, and touched up each other's faces-always keeping an eye upon us. We could not offer them any of our sandwiches and cake (as etiquette would have obliged us to do in other island groups), for Malekula is honeycombed with caste superstitions, and no man will touch food prepared at a fire used for cooking that of any other caste. Labourers on a plantation, preparing their evening meal, may be seen lighting almost as many fires as there are men, sometimes, before they will cook their food. . . Another of Malekula's many mysteries. Whence comes the caste idea, among such a degraded race? Whence, again, certain Jewish ceremonies, which are almost universal? Whence the four or five distinct racial types, and the six or seven entirely different 
languages, in this one island? Whence, above all, the purely Caucasian face that appears in certain of their oldest images? Why do the "hamals" or sacred houses, show an architectural skill never displayed in the miserable huts of the coast-though rumour says the towns of the interior are well and handsomely built? What is the truth about the pigmy men? What is the real significance of the figures of the "frigate" bird, that seem so closely interwoven with all their religious ideas? . . . Nobody knows; and, so far as I was able to ascertain, nobody cares very much either.

I went over to the group of fighting men by-and-by, to examine their decorations, and, if possible, converse with them a little through the medium of our boys. They seemed sullen and fearful, however, and disinclined to speak. A few women soon after appeared with loads of yams, and stopped to rest. They were evidently terrified at the sight of me, and most of them would not come near me. Those who did come regarded me with a scowling suspiciousness which I was far from returning, as I knew their presence meant that everything was right. More than once in just such mountain fastnesses as these has a too-venturous trader or recruiter, who had come up with an armed guard of his own, received warning that mischief was at hand by the sudden disappearance of all the women; and more than once the warning has been too late.

I picked up the basket of yams which one of the women had laid down, and tried its weight on my shoulder. It was amazingly heavy, and though I was nearly a foot taller than the wizened little creature who had been carrying it, I should not have cared to take it very far. The women of Malekula are bent and misshapen with the enormous loads they are obliged to carry, 
and their expression is, if possible, more degraded than that of the men. Pleasure of any kind is a thing unknown to them-there is nothing for them to enjoy from the pandanus-plait cradle slung over the mother's shoulder to the grave, which is only a hole scratched in the surface of the earth, unnamed and unremembered-if, indeed, anyone takes the trouble to bury the poor little corpse at all. I shall never forget the face of a bushwoman (who came down to the mission-house some days later, from another village, carrying yams for her husband to sell) when I gave her a pink ribbon and tied it round her neck. A sort of sacred joy seemed to overflow her whole countenance, and lift her far above the things of common earth. She seemed to feel ennobled and exalted by this wonderful thing that had happened. That she should have had something given to her-she, a woman! -and that it should be this marvellous piece of loveliness, this nameless thing of beauty! Surely the skies were going to fall! She was all one ecstatic grin until she went away, evidently treading on air and feeling six inches taller; and I was glad to know that her husband could not take the treasure away from her, as anything that had been worn by a woman might never afterward be allowed to disgrace the form of the superior sex.

The basket of yams was not an easy thing to handle, owing to its irregular shape, and I was careless enough to let it slip and fall to the ground, while I had it. Thereupon from all the fighting men rose a roar of laughter like the bellowing of a herd of bulls. I had not known they could laugh before, and I certainly did not want them to do it again. I asked for an explanation, and received it from one of our boys, in pigeon English of singular quaintness. ("Mary" is the pigeon English for "woman.") 
"Mary belong Malekula man; she carry yam all-atime," the youth explained. "Yam he break very quick, suppose you no put him down very good. You make him capsize, that-fellow yam; all a Malekula man he say: 'That-fellow Mary he no savee carry yam'-he plenty laugh."

It was my horrid ignorance, then, that had amused the Malekulans - the gross want of education I displayed in dropping breakable yams on the ground. Luckily, none were actually broken. "What sort of a woman is this-what use is she, that she cannot carry yams. Where was she raised? Who let her out?" were their obvious comments.

One does not enjoy being pilloried for ignorance, even in the wilds of the New Hebrides. I was quite glad when the procession moved on.

Later we came to a halt. Most of the men had gone on in front of us, and we could hear them singing and dancing in the village above. A dozen or so were loafing about the pathway, waiting for their turn to go up and join in the performances. Our native guide would not let us go on for some time, only answering our questions with: "Very good you no go firs'; that-fellow stop behin'. By-n'-by he go on, then you coming."

When the fighting men were all safely past us (I do not, and did not at the time, believe that they intended any treachery; our boys were rather a nervous and overcautious lot), we followed after, on the way to the town which now lay not very far above. 


\section{CHAPTER XII}

\section{MALEKULA-THE INNER MAN}

How a Malekulan Town is Defended-The Idol DanceFintimbus and the Pig-Gregorian Chant in the Wilderness-What are the Malekulans? - An Interview with a Cannibal Chief-The Lost OpportunityNo Admittance to the Temple-A Marvellous Mummy - The Bluebeard Chamber-Making of a Conical Skull-The Captain's Story

$7 \mathrm{HE}$ approach to the town was remarkable. For 1 some time before we reached the fence, the narrow foot-track ran double, and in places treble. One could not have found the right way unaided, save by chance, since the pathways wound about in a puzzling fashion that was evidently designed to mislead. At the last turn below the village, a cluster of bullet-marks showed conspicuously on the bark of a big tree. It looked rather as if the crack marksmen of the place were fond of practising long shots from above on this point-a good one for the effective picking off of undesired callers.

The town, when we reached it, we found to be approached through a narrow opening, very easy to defend in case of attack. It was surrounded by a stockade, and looked, on the whole, not the most peaceful place in the world. At the far end stood a single tall gabled house, the village hamal or temple. The other houses were a mere collection of miserable huts, roughly built of reed and bamboo, and with no walls to speak of. An open 
space in the middle surrounded a cluster of great drumidols, with the usual uncanny skull-like faces. A boy was beating these, so as to make a terrific din; and round and round the idols, in the brooding heat of the damp, gray afternoon, rushed the natives, running at full speed, and singing loudly as they went.

There was something curiously familiar to me in the whole strange, wild, horrible scene, although I had never, with my bodily eyes, looked on the like before. It was the very atmosphere of dreams that I felt-bad dreams of the restless small hours, when a wearied brain had revenged itself upon an overtired body by opening up a picture-book of ghastly nightmares, and fluttering the leaves from midnight until dawn before the sleepbound mind. The very air was thick and cloudy, like the air of dreams; there was only a stray gleam of sunlight every now and then, painting sharp Rembrandtesque effects among the shadows, as the ugly black figures fled endlessly past. The silence of all except the singers added to the illusion. Women stood far off in rows, dressed out with armlets of white pearl-shell, bead necklaces, and a small pandanus-woven scarf round the waist. They held a tall reed in each hand, and leaned on it, as they shuffled their feet silently, stupidly, noiselessly. Men, with an inch-wide belt of crimson fibre, set in an emerald-green satin strip of pandanus leaf, about the waist, and countless adornments of tortoise-shell cuffs, bracelets, and earrings, stood in motionless groups all over the village, looking at the dance. The drums thundered endlessly; the naked figures fled ceaselessly, with bent heads and rushing feet, round about the idols, while the wild, monotonous chant went on and on and on, as if it never would end. The heavy air, and probably a touch of the fever that is never very far away from the 


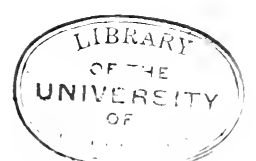




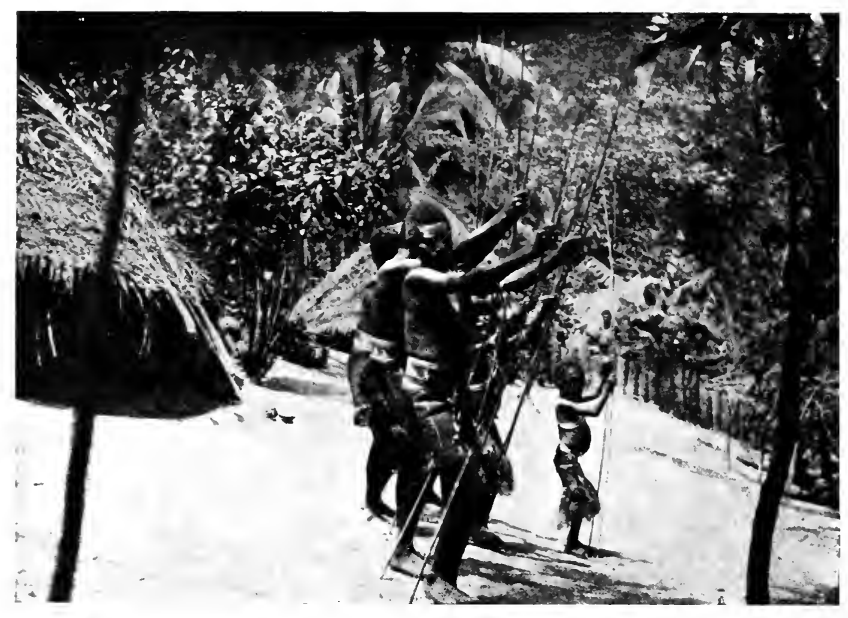

THE WOMEN'S DANCE

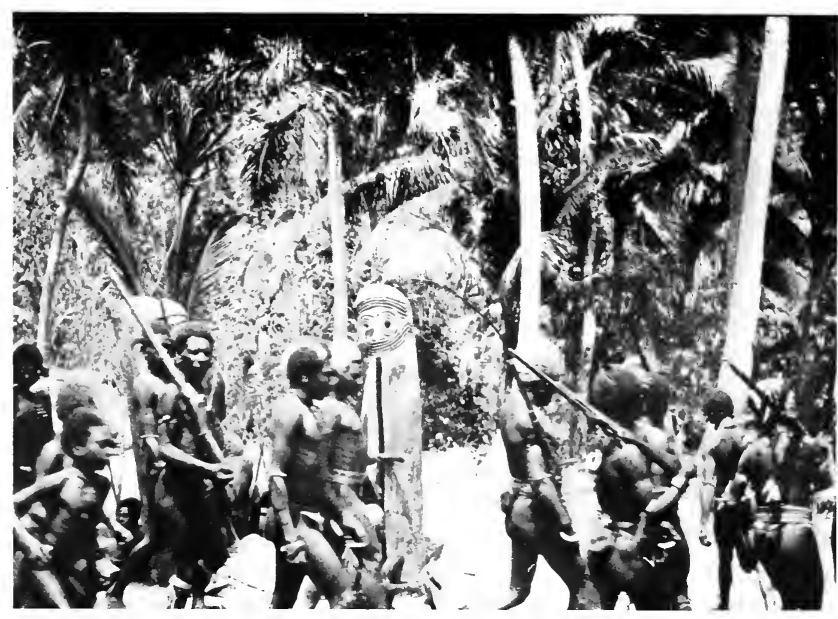

DANCING AND SINGING 
1Sıand traveller, added to the dream-illusion, until I could have sworn that I was somewhere at home tucked up (rather too warmly) in bed, and struggling with an unpleasant nightmare that would, of course, dissolve and vanish as soon as somebody came to call me.

Hour after hour, the dance went on; and the heat grew worse and worse, and the yelling of the chant, and thundering of the idol-drums, seemed to paralyse one's very brain. . . . I shall never be sure whether I did not dream the dance of Atamat and Fintimbus, which took place some time-any time-I cannot tell when-in the course of that bewildering afternoon.

If I did, I dreamed as follows. That Atamat, a notorious cannibal chief and a famous murderer, with a face like an iron devil, and limbs like the trunks of trees, came out by himself, and danced a solo dance over about half an acre of ground. The chant had ceased, the drums were silent; in absolute stillness he performed his dance. His bare feet made no noise upon the dusty earth; like some evil shadow, he flitted soundlessly over and over, and across and across the dancingground, using very little in the way of actual steps, but showing wonderful lightness and agility, although his immovable countenance and far-seeing eyes never for a moment altered or relaxed. At one period of the dance, it seemed evident that he was representing a bird of prey; and the representation was certainly excellentit was impossible to misunderstand the steady sailing motion, arms slanted or outspread, the short rising flutter, and the quick dart or pounce. If I mistake not greatly this is a cannibal dance, and used at sacrificial feasts for the way in which the dancer's evil eyes glanced over his audience, and the significance of the sudden short rush, were exceedingly suggestive. Atamat is a 
notorious cannibal himself, and there is certainly not a man in his village who has not tasted human flesh; for when such a dainty is on the menu, it is very carefully shared out all round, even the small children getting a bone to pick, to "make them strong."

("He plenty good ki-ki, one-fellow man," confessed an old man on the beach one day. "Plenty good, Missi -all same one-fellow chicken!")

There was no fear of a cannibal ending to-day, however; for all the women were in sight, and moreover, the Malekulans are modest about this little weakness of theirs. Like Kipling's hero, "They do not advertise" (when whites are about), and if they had contemplated a bit of baked man as a treat, it would not have been brought out. Nor is cannibalism an everyday occurrence. If a man is shot his enemies do not let his body go to waste, provided they can get hold of it, and revenge often fills the cooking-pots, but deliberate killing for the sake of eating is not common.

But the second part of the dance was still to come. Atamat had not long finished his solo, when a loud sound of chanting was heard in the distance. Nearer and nearer it came, and at last into the town at the head of a brave following stalked a young chief of some importance, named Fintimbus. With him Atamat immediately resumed the dance, his countenance as inexpressive as ever.

A pretty fellow was Fintimbus, according to Malekulan ideas. He had a head like a black feather-mop, adorned with a big green parrot-tail; his lips occupied half his face, and his skull was shaped like an egg. He was handsomely dressed in elbow-deep cuffs of solid tortoiseshell, a trade cartridge-belt, a boar's tusk worn locket wise on his breast, and a pig's tail in each ear. On his 


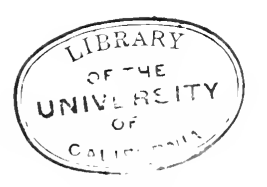




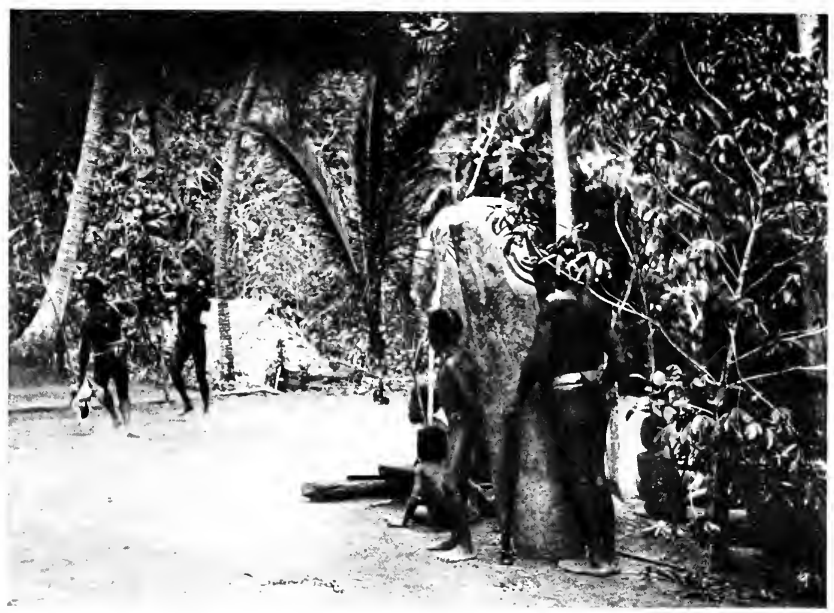

THE DANCE OF ATAMAT AND FINTIMBUS

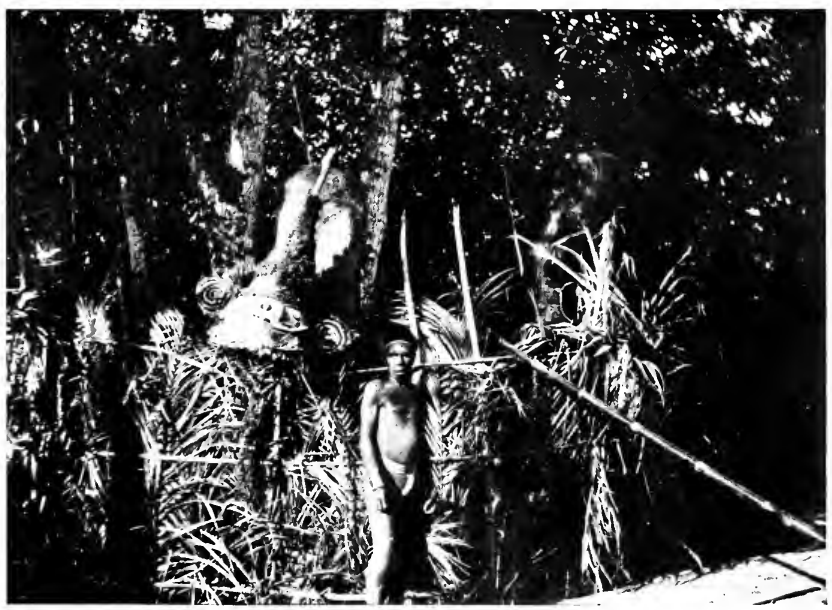

A DANCING MASK 
shoulder he carried a large black pig-alive-and with this singular cotillion favour he began gravely "setting to partners" to Atamat, who had now provided himself with a big bouquet of palm leaflets and crimson gingerflowers, and a conch shell a foot long-both things being extremely sacred in character, and also acceptable as I. O. U.'s for a pig in case you didn't happen to have one handy about the house. Fintimbus, it seemed, had made an offering of the pig he carried to Atamat, and the latter therefore was bound to furnish a "promise to pay" in return. The whole thing, I knew, had a symbolic meaning of some kind, but no one, then or thereafter, could tell me anything about it. . . . Alas for that scientific expedition that has never been to Malekula! Even an ignoramus like myself can understand that many dark points in the history of primitive races might receive light from a patient investigation of this tangled mass of nationalities, languages, and customs. Why, why, why? I kept asking myself through all that marvellous afternoon. . . . Why were the flowers, after being offered, laid reverently at the feet of a little idol that stood in a shrine by itself-why were the pigs considered sacred-and why, in the name of all things that drive men insane, was the dancing chant of this wild, degraded, unmusical people as like Gregorian chant as one pea in a pod is like another? I should certainly think I had been crazy when I fancied this, were it not that my missionary companion remarked himself that he had often thought these chants exactly like the sort of thing one heard when passing by some Continental cathedral!. . . No-there was no mistake. No choirsinger could fail to recognise that steady rise and fall, those sad minor cadences, those stately yet monotonous intervals. . . I do not say that the heathens of 
that cannibal town sang Gregorian chant as we know it, while they danced with cocked and loaded guns round the idol-drums in the square, but I do say that the two things were cousins, and not far-off cousins at that. If anyone wants an explanation, I can only recommend him to go to Malekula and look for it, and pray for better luck than mine.

Atamat and Fintimbus danced, I think, for about an hour, and then stopped. I do not know why they stopped; there seemed no reason why they should not go on for ever. It seemed to me then, as they had come to an end, that I ought to seize the opportunity of interviewing such a celebrated personage as this notorious chief, so I went up to him, and tried to carry on a conversation, with the help of a mission boy who didn't know Atamat's language at all well, and certainly knew very little of mine.

Atamat is not what the suburban lady would call a "nice gentleman." He does not wear clothes, he has no manners to speak of, and he has a way of looking right through you, as if he saw something unpleasant just behind you, but didn't think it, or you, worth mentioning, that is rather disconcerting. I offered him my hand; he took it, looked at it, and gave it back, with a countenance devoid of any expression whatever. I gave him some tobacco; he grabbed it without looking at me, bit a piece off, and turned his shoulder on me. I wanted very much to ask him "How it feels to be a cannibal" - but I was quite sure the boy was not equal to that, so I told him I thought his dancing very good. At this, he burst out into a wild chant celebrating his own virtues and excellences, handed a yam and a taro to the boy as a return for my tobacco, and walked off, still chanting. And that was all the notice he took of my insignificance, then or afterward. 
$E$ 


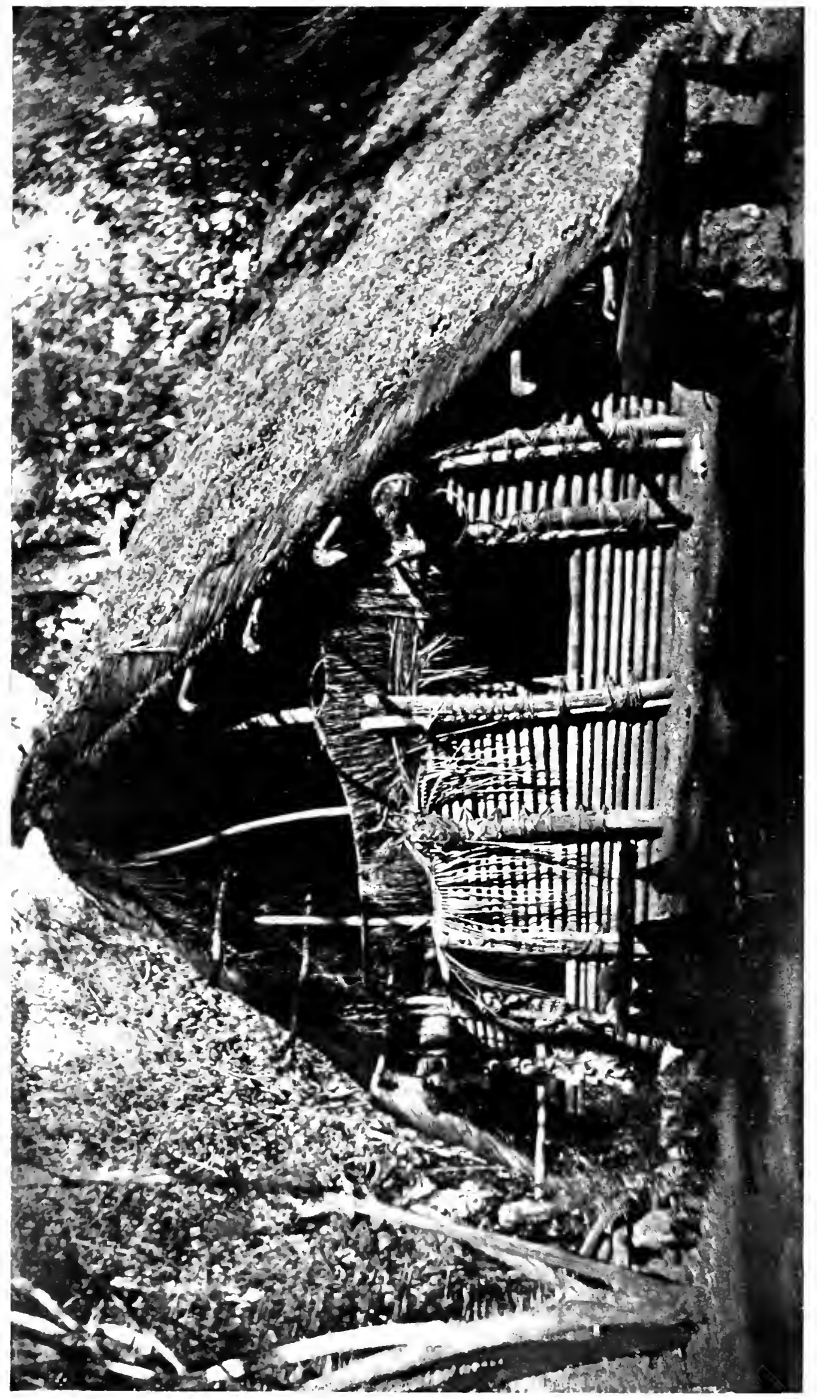

产 
An enormous tusker pig was then led in, as an addition to the coming feast, by a procession of much be-painted men, who entered the villages talking slowly, and singing as they went. The dance had now gone on for several hours. I was decidedly bored, and our guides were getting anxious to be away, as it seemed evident that our presence was not enjoyed, though not actually resented. Sullen unsmiling faces had watched every movement we made since we entered the town, and there was an atmosphere of "To-what-do-we-owe-thispleasure?" that was both unflattering and chilling. Of one thing I was quite certain, long before the afternoon was over-that Mr. B- had been in the right when he asked me not to bring my little revolver with me, and told the mission boys to go unarmed, like himself. The Malekulan is above all things suspicious, and the close watch kept on our movements was evidently intended to detect our intentions up there. Our only way of assuring the people that they were harmless, was to bring no possible means of doing harm.

I think the desired impression was conveyed, for just before we finally made up our minds to start home, a sinister-looking personage swaggered up to us, and said in fairly comprehensible pigeon English something or other about "the Frenchman." Mr. B-turned to me and remarked: "That's a celebrated character -the fellow who killed poor G-.".

"Yes, I killum all right," said the man with childish vanity, watching to see the effect of his words. I wanted to secure a photograph of the criminal who had eluded the pursuit of English and French men-of-war alike for several years; but this was no simple bushman of the hills, and he quickly got out of range of my camera. 
Indeed, he slipped away into one of the huts, to be quite safe. . . .

. . It was several weeks after, and I was talking to a British naval officer, in a civilised house near Vila.

"Why," said the naval officer, almost tearing his well-groomed hair with disappointment- "why on earth did you not bring him down with you when you had him?"

. . Six miles from anywhere, up in the fighting country, in a town unknown to whites-Mr. B-, myself, the boat-boys, with a pen-knife and two hatpins among us for arms, against two or three hundred murderous savages, provided with rifles, and very easy to offend. . . I am content to acknowledge that I thought the order too large to execute, and think so still. If one had been Deadwood Dick, or Captain Kettle, and had lived in a book, where all things are possible, the outlaw who thus amused himself by defying the whites would certainly have lived to repent his rashness. $\mathrm{Mr}$. $\mathrm{B}$ - and I would have hypnotised the two or three hundred warriors, tripped up and secured the murderer by means of a timely display of "jiu-jitsu," and made the boatmen carry our capture down to the shore-or else we should have timed our visit to come off just as an eclipse was due, prophesied its arrival, and assured the tribes that the sun would never come out again unless they gave up the murderer to us to take away. That would have made an excellent chapter, and proved in a flattering manner that two Britons are equal to two hundred niggers any day in the week.

But I did not live in a book then, dear reader, though I am living in one now-so I let the outlaw go, and strapped up my camera for departure, only concerned about the fact that we should be very late for supper, 
at the rate things were going. And then we walked single file out of the wolf-mouth entrance to the cannibal town, and started away down to the coast once more.

The dance we had been seeing, I understood, was the last of the dancing season. It is only at certain times of the year that the Malekulans get up these fêtes. The missionaries say that there is some connection with the gathering of the yam harvest; and, so far as I could ascertain, there seems certainly to be a flavour of heathen "harvest thanksgiving" about the proceedings.

Circumstances obliged me to make a much shorter stay in Sou'-West Bay than I should have wished. I was acting as correspondent for a colonial newspaper that wanted an account of the native troubles at that time prominent in the group; so a week or two was all I could spare for the wonders and mysteries of the Bay district. Two other days, however, were full of interest almost equal to that of the "harvest thanksgiving" afternoon.

On one, we went to a curious little village on the borders of the inland fiord or lagoon. You came to this village by two well-defined separate paths, approaching it in different directions. One was intended for men, the other for women. The tribes of the valley-who spoke a language quite different to that of the tribes of the hill above-did not allow women to walk upon the same pathway as the "superior" sex. Further, in this part, every married woman was distinguished by a dark gap in the ivory-white teeth of her upper jaw, where the two middle incisors had been knocked out with a stone. This extremely unpleasant substitute for the wedding-ring is found in various parts of Malekula. The operation is performed by the old women of the tribe, who greatly enjoy the revenge they are thus enabled to 
take on the younger generation, for the injury once inflicted by their elders upon them.

Our party, it may be noted, took the men's path going up to the village. A native woman would have been promptly knocked on the head if she had committed such a sacrilege, but we knew that, so near the coast, the people would not resent my walking over the tabooed ground, and it is always advisable, among savages as degraded as these, to emphasise the fact that the white race must not be expected to conform to native regulations.

There was no getting round the "regulations," however, in a matter of very much more importance-the question of seeing inside a hamal, or sacred house. A village right on the coast, where the people had quite a decent reputation, possessed a remarkably gocd hamal, and I was very anxious, the day we visited the place, to go inside. . . . It might have been scientific ardour, or it might have been feminine curiosity-I could not undertake to say. Anyhow, I wanted to get in very badly. But the natives would not hear of it. Mr. B- asked, I entreated, we both offered bribes. The men were firm. I should not go in, they said. I should not even put my head inside to look. Mr. Bmight go if he liked; not the woman, on any account whatever.

Mr. B - went in, and came out enthusiastic in praise of what he had seen. He had been into many hamals, he said, but never had he found such carvings and such mummies. The latter were there in bunches, hanging up against the walls and roof-tree. It was a terrible pity I could not see them, for no museum in the world contained a specimen, and very few people even knew that they were made. But the men all had guns, 


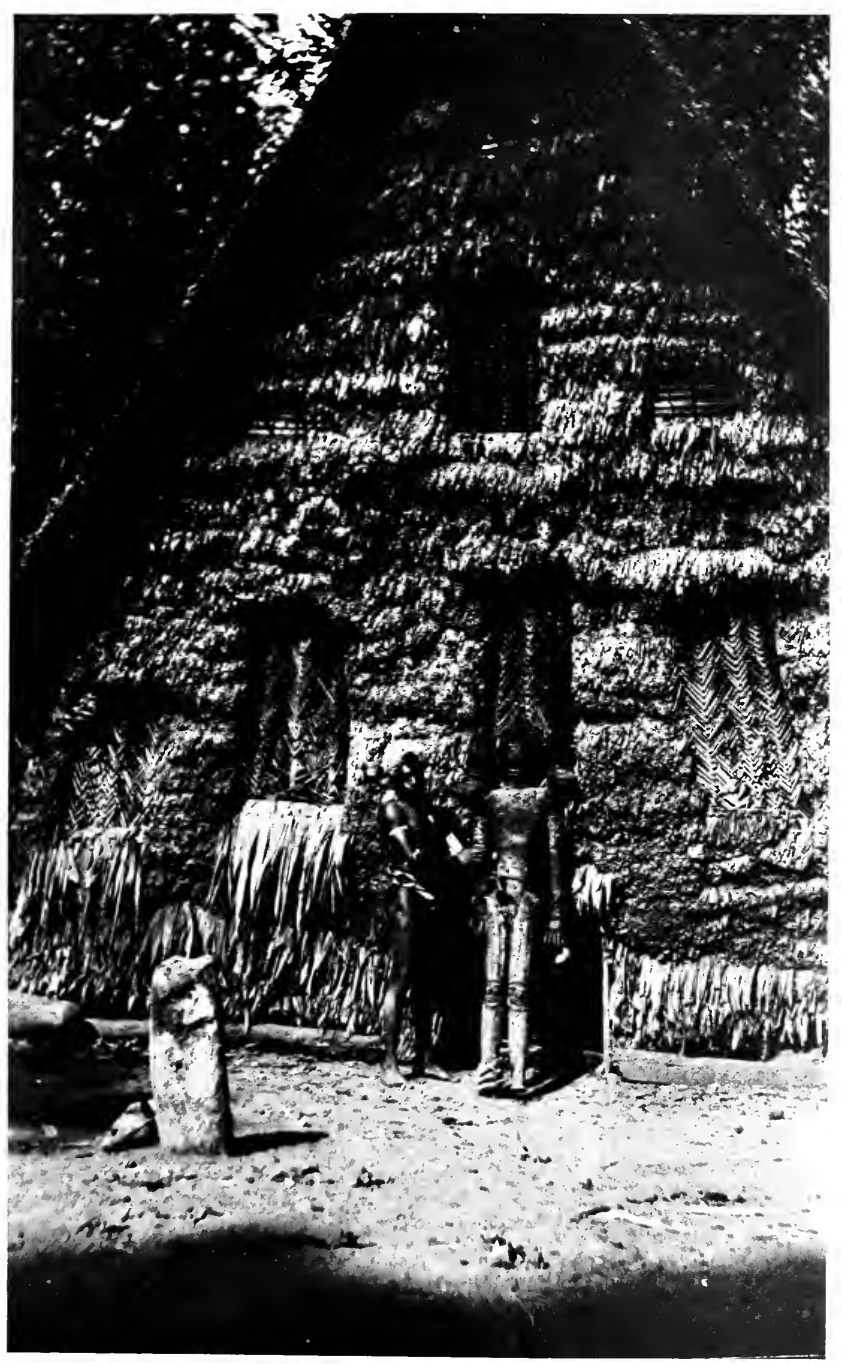

IBRINGING OLT THE MUMMY 


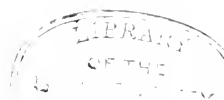


and they were extremely emphatic about the question of my entry. It was clearly no use.

We then set to work to persuade the villagers into at least bringing out one of their mummies, that I might photograph it. At first they refused flatly, but a good deal of worrying, and a little plug tobacco, at last brought success. One rather good-natured-looking youth (he belonged to the highest type of Malekulan, a fairly wellfeatured kind) went into the hamal, and produced a wonderful thing, which he set up against the gable, warning $\mathrm{Mr}$. B- not to let me come too near, or touch the sacred object.

It appeared to be the stuffed skin of a man, fastened on poles that ran through the legs and out at the shoulders. The fingers of the hands dangled loose like empty gloves. The hair was still on the head, and the face was represented by a rather cleverly modelled mask made of vegetable fibre, glued together with bread-fruit juice. In the eye-sockets, the artist had placed neat little circular coils of cocoanut leaf, and imitation bracelets were painted on the arms, The face and a good part of the body were coloured bright red. The ends of the stretcher poles were carved into a curious likeness of turtle heads. Standing up there in the dancing light and shade of the trees, against the high brown wall of the hamal, the creature looked extraordinarily weird and goblin-like. It had a phantom grin on its face, and its loose skinny fingers moved in the current of the strong trade wind . . . it certainly looked more than half alive.

Well, I was glad to have seen it, but it is certainly not the sort of object I should care to decorate my own hall with, as I understand a local resident has done with one that he was lucky enough to get as "loot" during a recent punitive raid. That is the only occasion on which 
one could secure a specimen of these remarkable mummies. No money would tempt the natives to part with one, voluntarily.

I may here add that I did succeed in seeing the inside of a hamal later on-near Uripiv, along the coast, if my memory is not at fault as to the name. It was during the leisurely tour in the steamer down toward Vila again. The hamal was near the shore, and I came upon it during the course of a walk with one or two passengers. It was not nearly so handsome as the building in Sou'West Bay, but as it stood by itself, and as there was nobody near except a few unarmed old men and a woman or two, it presented a chance which I should have been sorry to miss. I hastily got over the bamboo fence and went inside, in company with the other passengers. It was very dark, and at first we could see nothing, but by-and-by we were able to perceive a number of skulls carefully laid away on shelves, like pots of jam, and a dozen or two mummies, hanging up on the supporting posts of the roof. Some of these were like the figure I had seen in Sou'-West Bay; others seemed to be simple skeletons covered with vegetable padding painted red. There were also adzes, killing-mallets, and drum-sticks of various sizes, curiously carved into the likeness of semi-human faces, and painted roughly in colours. The whole place smelt far from agreeably, and I did not want to be caught, in case the old men went off to tell tales, so I came out after a few minutes, and went down to the ship again, as it was getting near sailing time. Afterward, I heard that my sacrilege had been seen, and that it was in consequence very fortunate for my health that I had the steamer waiting outside to take me off.

I am inclined to think that if ever I go back to Male- 


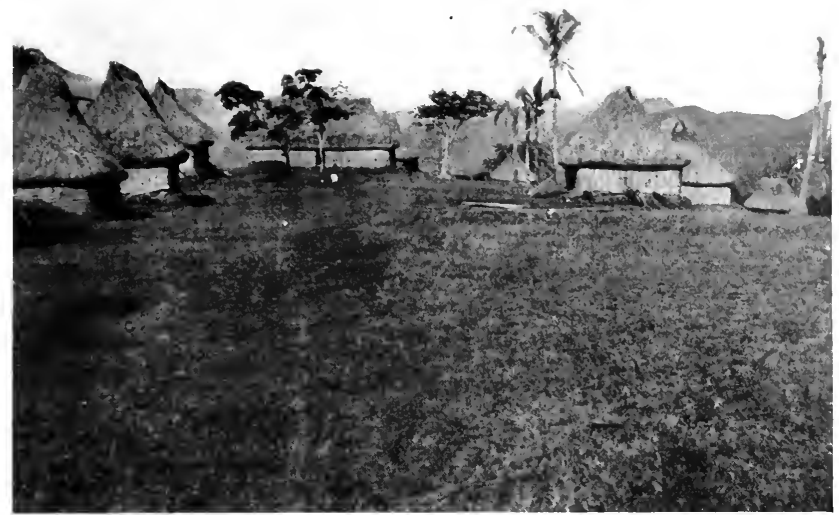

TOWN OF LEMBA-LEMBA

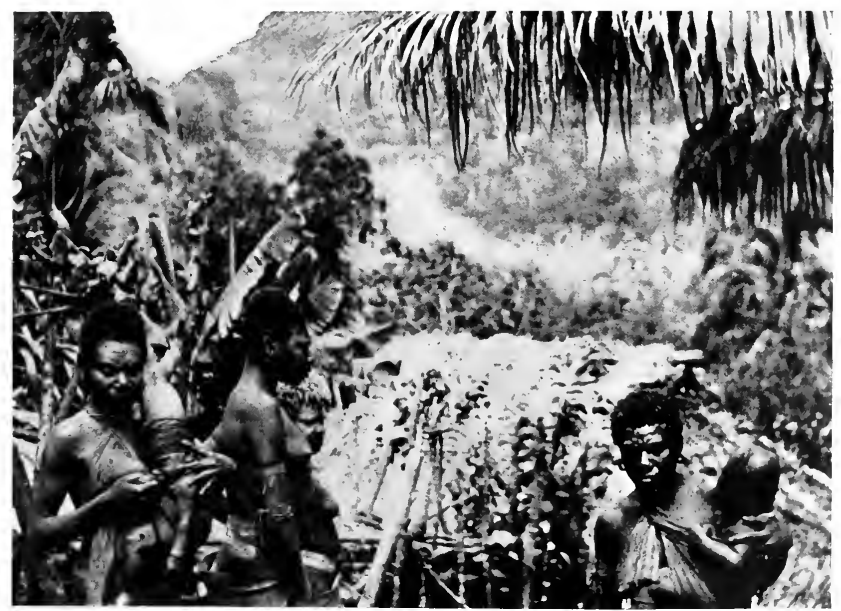

INFANT HEAD-BINDING 


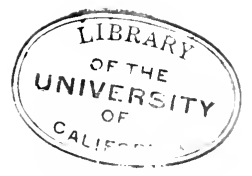


kula, I shall do well to avoid the neighbourhood of that hamal. But anyhow, I saw the Bluebeard chamber!

It was while I was staying with the kindly and hospitable $\mathrm{B}-\mathrm{s}$ (there are four families in the New Hebrides whom I shall always remember with infinite gratitude. and the $\mathrm{B}-\mathrm{s}$ are one) that $\mathrm{I}$ had the chance of photographing what I believe has never been photographed before-the making of a conical head.

A good many years ago, certain men of science who had procured skulls from all parts of the world were struck with the extraordinary egg-like shape of some that came from Malekula. No one knew much about the people who owned these remarkable heads, and Science, forthwith, erected rather a pretty theory on the basis furnished by the skulls, placing the owners on the lowest rung of the human ladder, and inferring that they were nearer to the ape than any other type at that time known.

Later on someone happened to discover how it was that the skulls came to show this peculiar shape, and the marvel vanished, when it was known that compression in infancy was the cause. It is still, however, a curious thing enough. Several other nations compress their infants' heads, but none seems to attain quite such a striking result as the Malekulan, in those districts where the custom is systematically practised. A conical head, when really well done, rises up to a most extraordinary point, and at the same time retreats from the forehead in such a manner that one is amazed to know the owner of this remarkable profile preserves his or her proper senses--such as they are. I could not hear, however, that the custom was supposed to affect the intellect in any way.

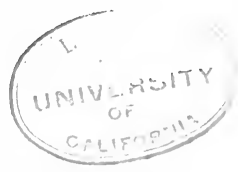


("It would be hard to affect what they haven't got," observed a trader, on this subject.)

The conical shape is produced by winding strong sinnet cord spirally about the heads of young babies, and tightening the coils from time to time. A piece of plaited mat is first put on the head, and the cord is coiled over this, so as to give it a good purchase. The crown of the head is left free to develop in the upward and backward fashion that is so much admired. One fears the poor babies suffer very much from the process. The child I saw was fretful and crying, and looked as if it were constantly in pain; but the mother, forgetting for the moment her fear of the strange white woman, showed it to me quite proudly, pointing out the cords with a smile.

She had a normally shaped head herself, and it seemed that she had suffered by her parents' neglect of this important matter, for she was married to a man who was of no particular account. A young girl who was standing beside her when I took the photograph, hađ evidently had a more careful mother, for her head was almost sugar-loaf shaped. It is interesting to know that this well-brought-up young woman had married a chief.

Malekulan skulls are considered rather valuable curios in these days, and it is hard to obtain one. I succeeded in getting a native of Sou'-West Bay-never mind how-to steal one for me out of a temple. I do not know what happened after, but I am quite sure that my coloured friend took good care of his own valuable skin.

The captain of the steamer rather envied me my acquisition, when I came to go away. He had one, but it was not such a good specimen. The story of its acquisition, however, is worth repeating. 
"I wanted a skull for some time, but I couldn't hear of one," said the amiable sailor. "However, last trip but one, a fellow with a sack came up in a canoe and said he'd something for me. I told him to come aboard, and blest if he didn't tumble out on the deck a raw new head, eyes in and hair on and all! 'What the, etc., etc., do you mean,' says I, 'bringing that filthy thing on to my ship?' 'I think you wantum one-fellow head,' says he. 'So I do,' says I; 'but I don't want a dirty thing of that kind; it's a nice clean skull I want,' says I; 'and what's more, my man,' I says, 'I'd like to know where you got it anyhow, for you're a pack of murderers, the lot of you.' 'Oh, he all right, he right,' says the fellow in a terrible hurry; 'plenty all right, I tell you! Pappa belong me, he go finish yes'erday, and I bring him head; I think you give me big-fellow tobacco!' ('My father died yesterday; I have brought his head; give me a great deal of tobacco.')"

"I did get a skull after all, next trip," he added, reminiscently, "and I put it into a basin of carbolic to soak, though it looked all right. And, as I'm a living man, if a cockroach the size of a mouse didn't run out of each eye, and one out of the nose, and there they sat on the top of the skull and grinned at me! . . . Where are you off to? It isn't near tea-time yet!" 


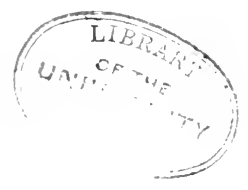




\section{CHAPTER XIII}

\section{MALEKULA-PAGAN AND WARLIKE}

Idols of the New Hebrides-The Famous Poisoned ArrowsThe Threatened Schooner-The Breaking of Navaar -An Ill-natured Sea-Chief

N THE subject of the idols of Malekula there is at least a volume to be said, but it must wait for speakers more competent than myself. I did not go up to the New Hebrides to make scientific observationsfirst, because I was not qualified to do so in a manner that could add anything worth having to scientific knowledge in general; and secondly, because I went to the islands partly on business, and largely for funtwo objects quite incompatible with serious research, even if I had been capable of the latter.

For all that, no one possessed of a decent education and an average share of curiosity could journey through these mysterious, little-visited islands without constantly "wanting to know" (like Rosa Dartle) a hundred things that no one can tell; and most of them are connected with the images of idols. The missionaries, for whom I have every respect, are unable as a rule to help. The magnificent opportunities which they, and they only, enjoy in these islands would make any scientific man tear his hair with envy-embittered envy, too, since no use, as a rule, is made of these rare facilities by those who possess them. I do not see, however, that the missionaries are to be blamed. Their education, 
being strictly specialised, has not been of a kind to lead them to take interest in such matters, or to realise their importance; moreover, their case, as they put it themselves, is reasonable. They are too busy, they say, destroying all these customs and beliefs to waste time in studying them, and too much interest displayed toward them would hamper their real work, by leading the natives to suppose that "heathen" ideas were worth consideration. One may respect such a position, while strongly disagreeing with it.

Some missionaries, however, have been sufficiently interested in the strange customs about them to take notes that may be really useful, especially in time to come, when the advancing wave of civilisation shall have swept away much that survives at present. Among these is Mr. Watt Leggatt, to whom I am indebted for permission to quote the following article from the Journal of the Royal Anthropological Society of Australasia:

"A visitor to the island of Malekula, New Hebrides, is greatly impressed by the huge images in the amils or village squares; they are rudely carved and barbarously painted. His first idea is that they are idols, but he learns that there is no worship paid to them after they are once set up. On being told that they are temes, or images of the dead, he naturally concludes that they are representations of distinguished chiefs who have become demi-gods.

"Now while it is true that the Malekulans do, in circumstances of danger, e.g., in a storm, shout appeals to their grandfathers for help and protection, yet these images do not represent the apotheosis of individual ancestors recently deceased. There is a very general opinion that such is the case, but a little investigation shows it to be erroneous.

"I think that they are rather the representations or tutelary spirits of the different ranks, grades or castes into which Malekulan men are divided. These are divided from each other by many barriers, the most striking of which is that no man of rank can eat food prepared on the fire of one lower. He cannot even light his 
$\infty$ 


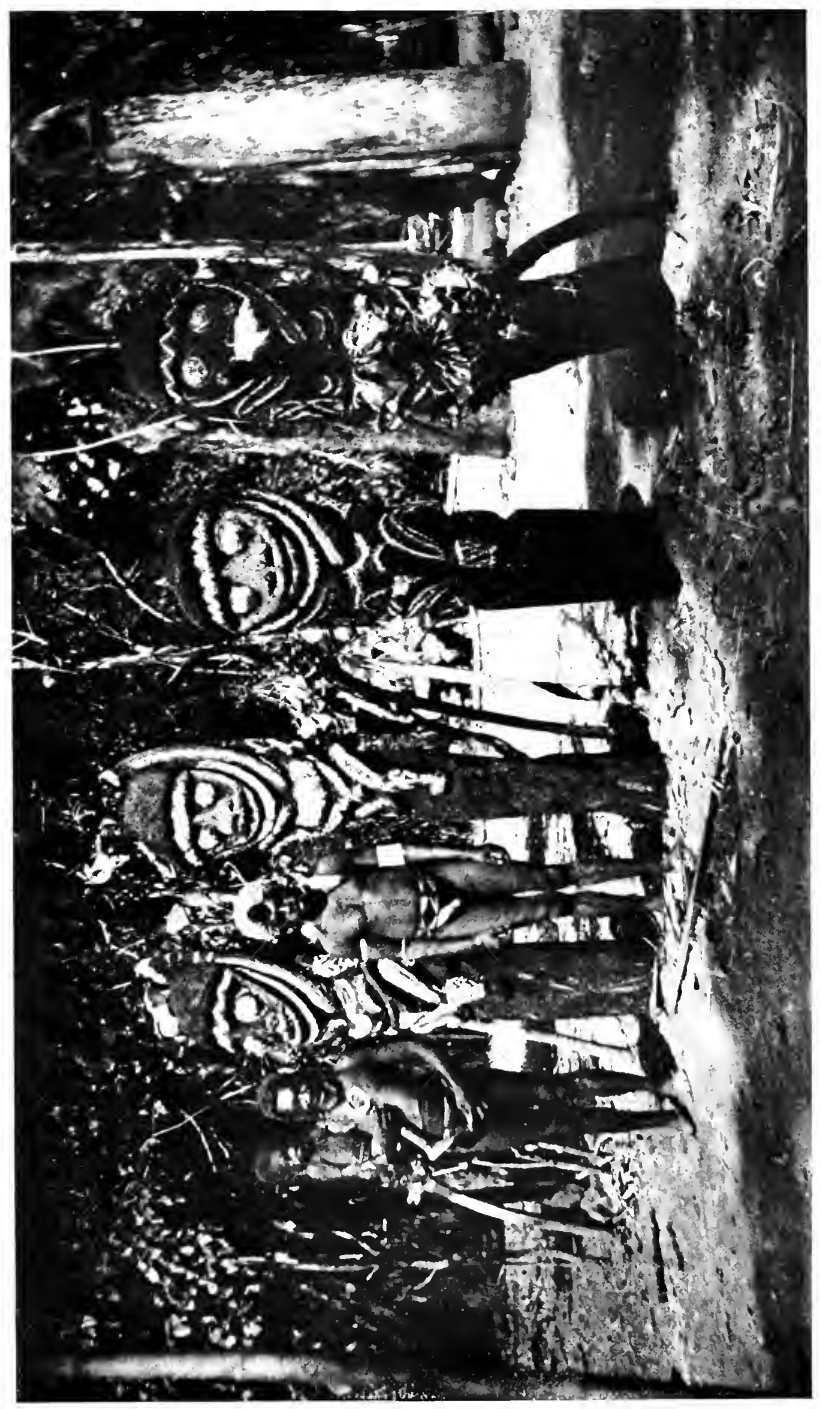

ह 
fire with a brand from the other; but must make a new fire either with matches or the old-time fire-stick.

"It will be noticed that these Temes, Demits, or Natemate differ greatly from each other. Some are made of wood, others of the butt of a fern-tree, some are painted in scrolls or stripes, others in rings. Some display only a head, others are rude effigies of the whole human body. In some the eyes are round, in others oval-shaped, and curiously it was this trifling difference that first attracted my attention.

"As the images were always spoken of as the property of some one or other, and noticing that each man erected a new one for himself, I naturally concluded that they were memorials of his ancestors. The ignorance of the present generation as well as the reluctance of the older men to discuss such subjects for a long time prevented further knowledge. By degrees, however, I noticed that an image of a different kind was set up by the same man as he advanced from one rank to a higher.

"Quite lately while visiting the Maskelyne Islands on the south-east coast of Malekula, the whole matter was cleared up. The people there are perhaps deficient in the artistic skill of their fathers, or may be while enjoying the festal rites, singing, dancing, killing and feasting on pigs, they grudge the time spent in searching for suitable trees or laboriously carving out new gods. Like impecunious students at some of our universities who purchase or hire second-hand gowns or hoods to enable them to pass for their degrees, our Maskelyne Islanders buy the necessary Natemate from their pastmasters, and resell them when they step higher. He must, however, retain it while he remains in the rank it denotes, and if he dies in that degree it is planted at his door.

"I have read of a similar custom in the island of Maewo, where the ownership of some valuable mats is eagerly contested. Too fragile to be removed, they hang, smoke-begrimed, in a dingy hut; but the honour of being known as their possessor amply compensates the man for the pigs he has paid for them. Of course, he can always get value for them by passing them on to another.

"In the Maskelynes there are ten grades, each with its distinguishing Natemate.

“( (I) Taresing. For which four boar pigs with tusks are paid as initiation fee. The image is a rough post, five feet high and six 
inches in diameter. It is called Nahau, has a face roughly carved at the top, and is painted blue and red.

"(2) Balanrum. Six pigs. The image called Savanral is somewhat like a cross with the arms sloping upward. It is painted in scroll designs in red, white, and blue. The head is painted black, with little white feathers plastered over it.

"(3) Alunk. Six pigs. A fern-tree image called Bataru, six feet high, coated with brown clay on which black designs are traced. At the back of the head two short shafts stand up like the handles of a wheel-barrow.

“(4) Matalau. Nine pigs. The image called Lovwis is a long fern-tree trunk, carved with human figures or faces. They have all got short sticks through the septum of the nose.

"(5) Bwiliau. Twelve pigs. The image Ambang is like Savanral but is painted entirely red. In front of it two tiny human figures called Mengov are set up. They wear caps of dried cocoanut husk.

"(6) Bwilbon. Thirteen pigs. Bwila. A short figure of wood, painted in scrolls of red, white, and black, with boar's tusks from the jaws to the ears. There is hair on the top of the head.

"(7) Vilvilbon. Thirteen pigs. A large fern-tree figure called Vilvil.

“(8) Balias. Ten pigs. Short figure painted in red perpendicular stripes.

“(9) Meleun. Ten pigs. A figure about seven feet high, painted in red and black perpendicular stripes. It is placed under a thatched roof. Behind it is a small circle of flat upright stones.

"(10) Amat (high chief). I could see no image, but was told that it was a long carved pole. On another island I was shown a small carved stone image as the symbol of this rank. I am doubtful if this is so. For this rank ten boar pigs are distributed, and three killed. I have no doubt that there is a corresponding division in each Mangke, as the ceremony is called, but I had omitted to inquire at the time.

"There is an extra Mangke called Tan melev for which three pigs are killed. The image is a long pole of hardwood carved with human figures and faces.

"The colours employed in olden times were coral lime, yellow ochre, a mineral green, and charcoal. Civilisation through the trader has supplanted the green and yellow with laundry blue 
ater 

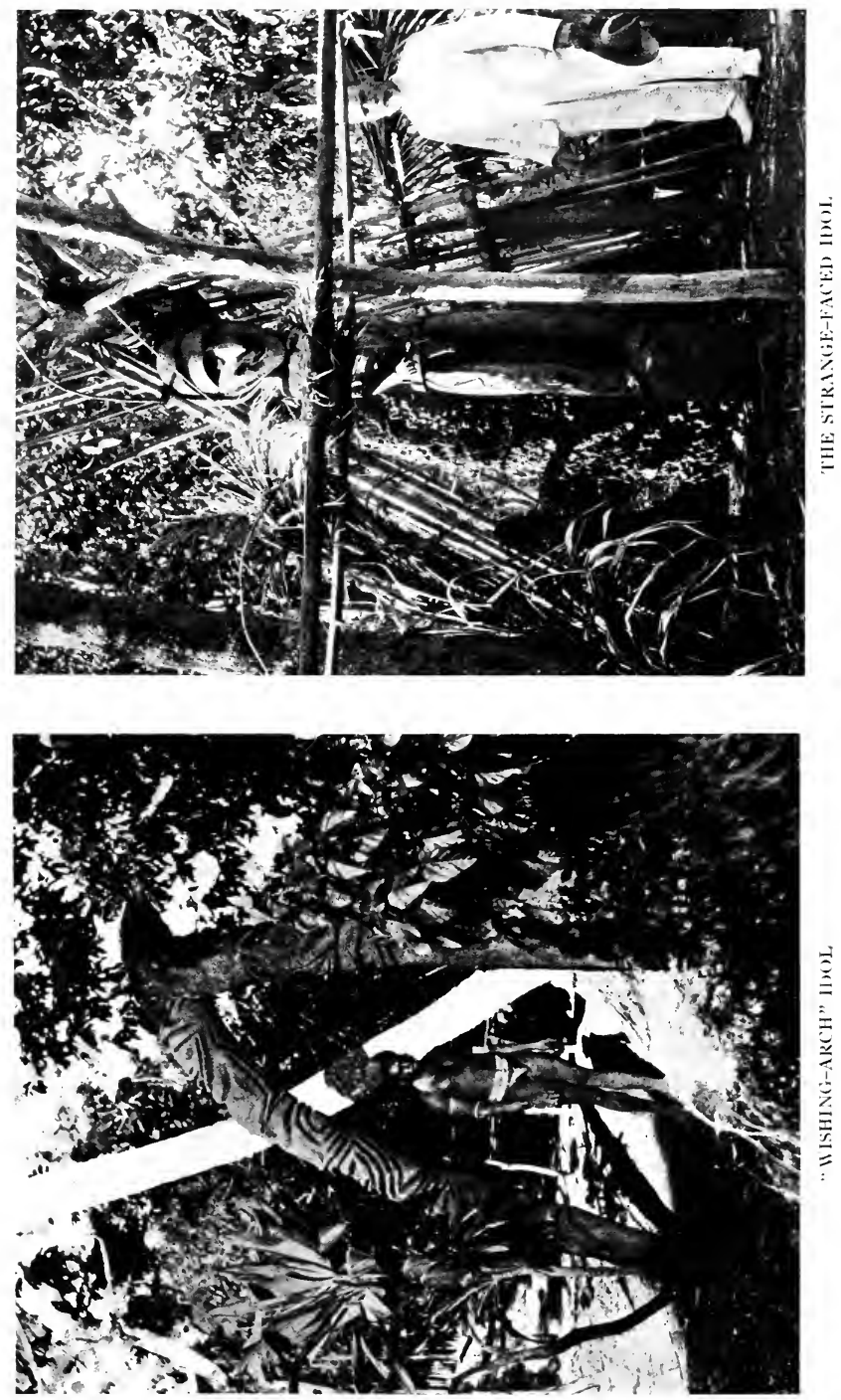
and red lead. They are more brilliant, no doubt, but less in keeping with their surroundings.

"A remarkable fact is, that although the images are rude in design, and out of all proportion, they are real attempts at portraying the human figure. Every part is carefully put in, yet with the exception of the boar's tusks on one there is an entire absence of the combination of the human and animal, as, e.g., in the Hindu pantheon. This is possibly due to imperfect and rudimentary notions of divinity, if these are at all gods. There are no figures like the Ephesian Diana denoting the nourishment of man and beast from many-breasted Nature. There are no many-handed or many-eyed emblems of the omnipotence or omniscience of the gods. We are still among the lowest and rudest forms of religion.

"It is noteworthy that there are no female figures, although there are some on North Malekula.

"The Natemate are set up round the Amil in no particular order that I could see. When set up, reeds and ornamental shrubs are planted round them, but only the highest were covered over.

"I hope others will pursue this interesting subject of which I have but touched the fringe. The imagery of North and West Malekula has many distinctive features which will repay a careful study. We know next to nothing about the symbolism of the huge drums, why some have one face and others have two, with three eyes so ingeniously arranged that they serve as a pair for each face. We are entirely ignorant as to the meaning of the great bird head and outspread wings projecting from the ridges of the shrines, and the prows of the canoes. I am sure that a knowledge of their meaning would solve much that is mysterious in Malekulan mythology, as many of their dances are representations of the dart from covert and flight of a bird. Possibly their meaning is as obscure to the present generation of natives as to ourselves, but there is still hope that an investigation undertaken now $>$ may bring important facts to light."

To this I can add a few notes of my own. The very curious idol in the form of an arch, which I have illustrated, does not seem to be at all common, and is evidently not known in the district of which $\mathrm{Mr}$. 
Watt Leggatt writes. On the mainland of Malekula, it certainly appeared to me that some sacred idea attached to all the images in general, and there was, I heard from a native some advantage (I could not make out what) obtainable by walking under the arch-idol. A curious parallel, this, to the "wishing-arches" familiar in our own country!

The image with a double face-one face being carved below the feet-is also, I heard, very uncommon. Its upper face was the one that interested me the most, from the peculiar type of the features. This, as I understood, is an image of a very old traditional type. It is hard, under the circumstances, to understand where the flatfeatured Malekulan obtained such an idea, for the features of the image are undoubtedly those of a higher race.

"Higher race-well, I don't know," commented an irreverent Australian who saw the photograph some weeks later. "Looks to me like the very living portrait of Mephistopheles in what-d'-you-call-em!"

There certainly is a flavour of the arch-tempter about the mocking face of the image. . . . Will some learned person kindly explain?

The question of the poison used for native arrows is rather a vexed one in the islands. They are very commonly carried, and opinion seems to agree on the point that a wound from one almost invariably causes death within ten days-generally about the ninth day. Most of the white people believe that these arrows are poisoned by being steeped for weeks in a decaying corpse. One or two of the missionaries, however, say that this is not the case, and that human bones, mostly dug up after burial, are used for the points; death, in consequence, being caused by blood-poisoning of an ordinary kind. 
I cannot say what the exact truth may be; possibly both statements are correct, as customs may differ in different places. I was fortunate enough myself, in Sou'-West Bay, to come upon a native carrying a bundle of poisoned arrows as used in that district, and, as one of the mission boys was near, I asked him to interpret my wish to see the arrows. The manwho, as the photograph proves, was a singularly uglylooking wretch, even for Malekula-unwrapped the arrows with a grin, and held them out to me to look at. They had long sharp points without barbs, covered so thickly with a brown gluey stuff that it was impossible to see of what the points were really composed. These arrows are always carried wrapped up in a neat little parcel of banana leaf, so as to prevent any accidental injury to the owner. The ordinary unpoisoned arrows have long iron points with a row of small barbs, and are carried without protection.

There is always the greatest difficulty in finding out anything about native customs, since the people are extremely reserved and distrustful, and the number and variety of languages makes it most difficult to exchange ideas. A native who can speak a little pigeon English may try to interpret but it is probable that he knows the other man's language imperfectly, and is incapable himself of even understanding the nature of your idea. "Dead man" is about as near as most people can get to an account of the manufacture of poisoned arrows. It is unsatisfying, if sensational.

On this particular occasion, I suspected that there was something not "purely Pickwickian" about the carrying of those arrows, so, after giving them back, and adding a present of tobacco, I asked ingratiatingly what the old gentleman wanted them for? He giggled, 
and made a reply which my interpreter translated as "For killum man." Pressed to give further details, he chuckled still more, and rapidly retreated toward the bush.

I was not at all suprised when a row of rather wild-looking "bushies," all armed, appeared from nowhere in particular, in the course of the next few minutes, and began hanging about the mission grounds. The boy said he was pretty sure they meant no harm to us, but he thought they did not mean any good to the recruiting schooner that had come into the bay overnight, for they had been asking angrily where were the friends that the schooner should have brought back to the bay from the plantations-and their behaviour was undoubtedly warlike. (What he really did say was something like this: "I no think that fellow he make bad for misinari; I think he plenty cross that schooner no takeehim come him friend!") The schooner in question was one that enjoyed a rather unsavoury reputation; she had been in trouble over illegal recruiting more than once, and no one would have been surprised to hear, at any time, that her owners had paid in blood the penalty of their bad faith-as so many before them had had to pay, among these lawless New Hebrides.

She had come into the bay the evening before, and had made the recognised recruiting signal, by exploding a piece of dynamite set adrift on a plank. Next morning, her two boats, painted vivid scarlet, the recruiting colour, had been out bright and early, but for some reason or other they had not ventured to run up on the shore and had merely been rowing up and down the bay.

Small wonder that they hesitated, if their consciences were ill at ease, in a spot like Sou'-West Bay, where over and over again the sands had been reddened with 
the blood of recruiting crews! The natives have long memories, and they pay back with compound interest, where they consider that they "owe one"-if, indeed, they do not attack out of pure wantonness, as sometimes occurs.

I got out the camera when I saw the party of bushmen coming down to the shore, and tried to take a photograph. These were sophisticated savages, however, and they were on an errand that they did not wish to advertise. So most of them hid their faces when they saw me focussing, and the resultant picture showed very little.

Warning would have been sent from the mission house to the ship, only that it proved to be unnecessary, for the boats, after a little more rowing about, were recalled to the vessel, and she set sail and went off without having landed a man. And the bushen, like the Snark, "softly and silently vanished away," and we all went in to tea.

The punitive expedition into the interior of Malekula, which took place in October 1905, a few days before my visit, had an excellent effect in calming down the island generally. It started from Bushman's Bay, and its immediate cause was the challenge sent out by the men of Navaar to the whole British Empire. They had been murdering stray whites, and carrying on a hot campaign against the natives of an outlying island, which endangered the lives of the missionaries and traders very seriously, as the people of Bushman's Bay fired recklessly night and day across the water, sending bullets right into the white settlement. Being told by the men-of-war people to send down the chiefs for a conference, and further, to stop that kind of thing 
at once, they sent a message to say that the man-of-war was an old woman, and that they declared war on England! If the white chiefs wanted to see them, they added, they might come up and do it. This was, of course, intended as a mere defiance, for Navaar (which had been brewing all the mischief), was eleven miles up in the mountain interior, and had never been even approached by white men.

The French and English warships, however, "had much pleasure in accepting the kind invitation" of Navaar. They brought a large party of bluejackets to the entertainment, and a Maxim gun or two; and they had surrounded Navaar, and placed the offenders in a position where there was nothing to do but submit, before the latter well knew where they were. After the prisoners were secured, there was a brief scuffle caused by the natives turning suddenly on their captors in a body. Several Malekulans were killed, and the British leader, Commander D'Oyly, had an extremely narrow escape from a fatal stab. But the rising was nipped in the bud ere well begun, and a number of very sad and sorry heathens went down to the shore that day, under strong escort. Later on, all were released under promise of good behaviour; which, strange to say, they kept. The claws of the worst fighting place in Malekula had been effectively cut, and white men and women's lives henceforth became possessions of reasonable certainty, down in the coast-lands below.

The note of comedy is never wanting in savage warfare. Wala and Rano, two of the islands on the coast, had been sternly told that they must stop their quarrels and make peace, because the lives of the whites were endangered by their rifle-firing across the water. A chief from Wala asked humbly to see the Great Sea- 


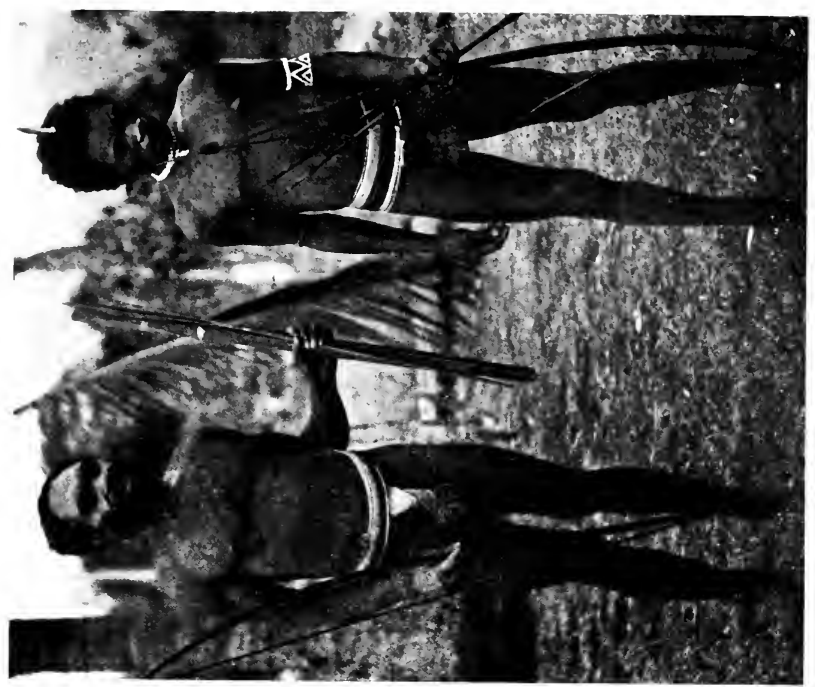

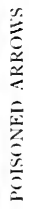

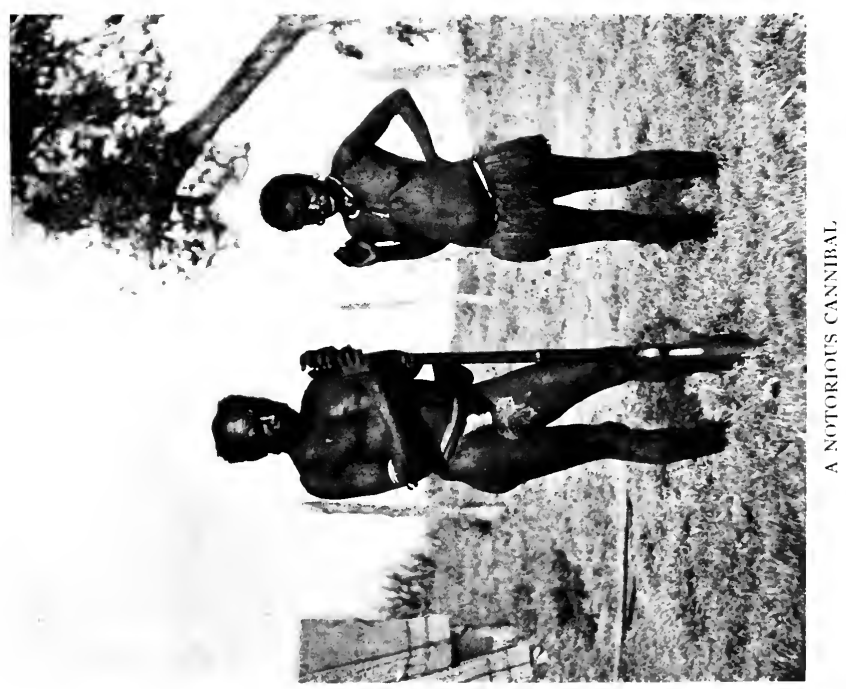




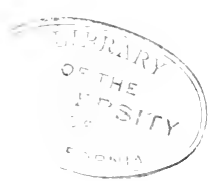


chief of the ship, as he wished to make terms. He was allowed to come on board the Pegasus where, according to orders, the bluejackets put him in a canvas tank, gave him what he never had had before in his life-a thorough scrubbing-before he was admitted to the presence of the captain. Trembling all over, and utterly subdued by this terrifying experience, he proffered his humble request. They would certainly make peace, he said-they would do all they were told-they would never fire a shot again-only, there was just one favour they would like to ask. Could the captain grant it?

"Certainly," was the reply. "Any reasonable request will be granted, if it is at all possible. What is it?"

It was a very reasonable request indeed, said the envoy, and the Great Sea-chief could grant it without any inconvenience. All they wanted, before settling down to peace, was that he should give them a man from Rano to eat! Just one, no more, and the captain might choose him for them-they would trust entirely to his selection.

. It is hardly necessary to report the reply they got. But I believe the men of Wala to this hour believe that the sea-chiefs of Great Britain suffer from strange prejudices, and are not at all good-natured! 
단 


\section{CHAPTER XIV}

\section{HOT TIMES IN TANNA}

Hot Times in Tanna-An Island of Murderers-The Terror that walks in Darkness - A Tannese Village-Avenging a Chieftain-Was it an Accident? - A Council of WarNetik-The Work of British-made Bullets

TANNA is the southernmost but one of the New 1 Hebrides and enjoys a rather better climate than the northern islands, although the fevers are quite as bad as those of Malekula or Santo. It is about twenty miles by ten; mountainous and rugged in the interior, and difficult to get about, as there are very few tracks, and those not of the best. It has no harbours to speak of, and the anchorages are bad.

This last statement did not excite my attention very much when I came across it in various local works of reference. It seemed to me that Tanna's deficiencies in that particular line were matters that concerned only the shipping companies and the captains directly affected by them. Myself they did not interest, or at least I thought so, until a certain November morning, when I found myself standing on the deck of a Burns Philp steamer, surrounded by all my wordly goods, and looking with a very blank countenance toward the biscuit-coloured coast of the island which I was going to visit, and upon which I had just been informed I could not possibly land. There was a tumbling blue-and-white sea on, and the captain declined to risk his boats. 
"What am I to do?" I asked.

"Go on to Aneityum," said the captain pleasantly. "We get there to-morrow, and there'll be a steamer back here in a day or so."

"And if the weather is no better then?"

"Why, you can go back to Vila, and try again in three weeks' time!"

The situation did not seem to admit of comment. I walked aft, and sat down in the midst of a clutch of Presbyterian mission babies, feeling very much like the Malekulan in a pet, whom I had seen coursing up and down his native shores not long ago, calling out at intervals, "Oh, I am angry! I want a man to eat!"

Two residents of Tanna, who were also desirous of getting off at Lenakil, watched the shore with excited interest. The sea began to go down a little, and it looked as if we might have a chance, should any shore boat venture off. And one did come off later on, dancing and skipping alongside the steamer after a fashion that made me thankful for my two years of "roughing" it about the Pacific. To the traveller fresh from home, the methods of landing passengers that obtain about the islands seem at first a very bad joke, and then a very unpleasant reality. Later, you grow callous; you become used to the dangling rope ladder skipping above the plunging boat, and the playful billow that drops a ton of cold water in your lap, and the unbroken reef that must be literally jumped on the crest of a wave, the narrow passage full of tumbling foam, and edged by coral splinters and pinnacles as sharp as broken glass; the squall that may get up at any inopportune moment, and maroon you for a month where you least desire to stay-and all the other little excitements that attend 


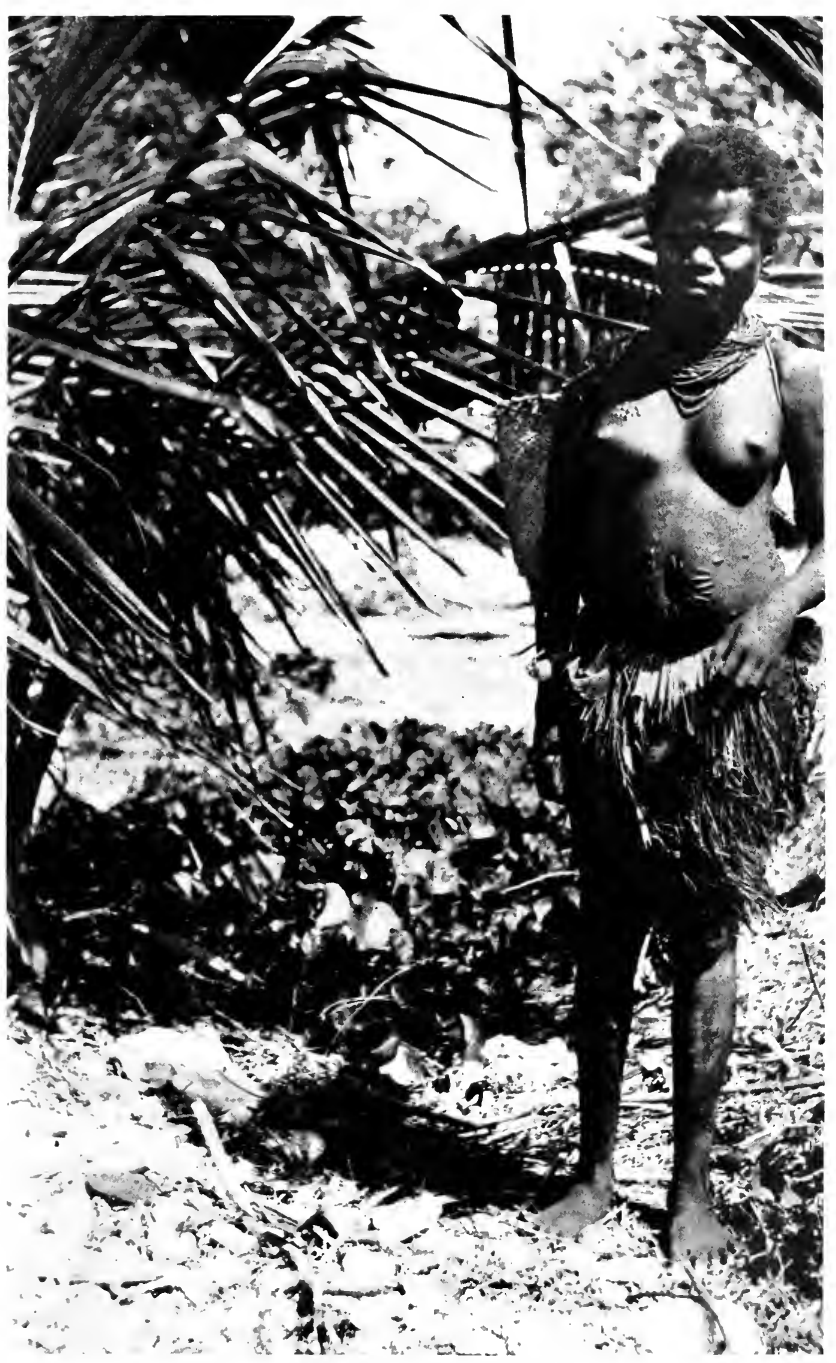

TANNESE SCAR-TATTOOING 


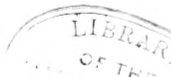


embarking and disembarking about the "sunny isles of Eden," beloved by poets who have never been there.

We landed safe and dry after all, the kind hosts who had invited me to share their home during my stay remarking pleasantly that I was on Tanna now, and I might think myself lucky if I got off again when I wanted, for the uncertainty of when you might arrive was only equalled by the uncertainty of getting away.

Tanna, we found on landing, had been enjoying a very hot time of late. Drought and bush fires had destroyed a good deal of vegetation, and the island looked dry and burnt up. The tribes were "at it again," and more than twenty murders (which is the Tanna form cf making war) had taken place in the last three months. The house and plantation of a well-known trader had been all but destroyed by a fire which was deliberately started by certain hostile tribes, to burn up each other's gardens.

Tanna is always fighting more or less, and its population-which could otherwise in all probability hold its own-is rapidly diminishing. It has about five thousand people, and seventy or more are shot each year-men, women, and children-besides a large number who are more or less seriously wounded. The arms used are mostly old Sniders and Martinis, with an occasional good modern rifle. The bullets are about the most brutal things ever fired from a gun. They are great lumps of lead, as large as the rifle can take, and have a very heavy charge of powder. When they strike they break, and inflict the most appalling wounds, splintering bones, tearing out flesh by the handful, and scattering destruction almost like a small shell. I could not ascertain where they were made, but they seemed very like the kind of thing generally used for elephants and other big game by sportsmen. I have heard it suggested 
that they are a special manufacture, and meant for just the uses to which they are put. The maker, in any case, is too modest to stamp his name on his work.

The Tanna people are a remarkable race, and, in spite of their murderous tendencies, have a great deal more character than the Malekulans. Queenslanders know them well, for thousands of Tannese have been employed in the Queensland sugar country from time to time. Whatever they may have gathered of civilisation in Australia stays with them but a little while after they leave. On landing they generally take off all their clothes, go back to their villages, paint their faces, and take a hand in the latest tribal row, only too glad to be back to savagery again. They let their hair grow, and engage a hairdresser to do it in proper Tannese style-no trifling job this, since it means an hour or two a day for many weeks.

The hair is divided into minute locks of about a score of hairs apiece, and each of these is wound round from the base to within a few inches of the end, with very fine fibre, so that the lock looks exactly like a piece of tough twine, with a bushy tassel at the end. When the whole head is completed, the effect is very striking, as there are many hundreds of these tassel strings, ending in a great bush upon the shoulders. A fillet of some kind confines the hair over the forehead-a scarlet trade ribbon, a strip of satiny-green pandanus leaf, or sometimes what looks like a long hank of tiny amber beads on a flossy white skein of thread. This last is not what it seems, however, being in reality a kind of fish-spawn, often found in masses floating on the sea.

Most of the men wear armlets-a circle of carved cocoanut, a trade bracelet made of china, or a strip of dried grass, with a gay bunch of scarlet flowers thrust 


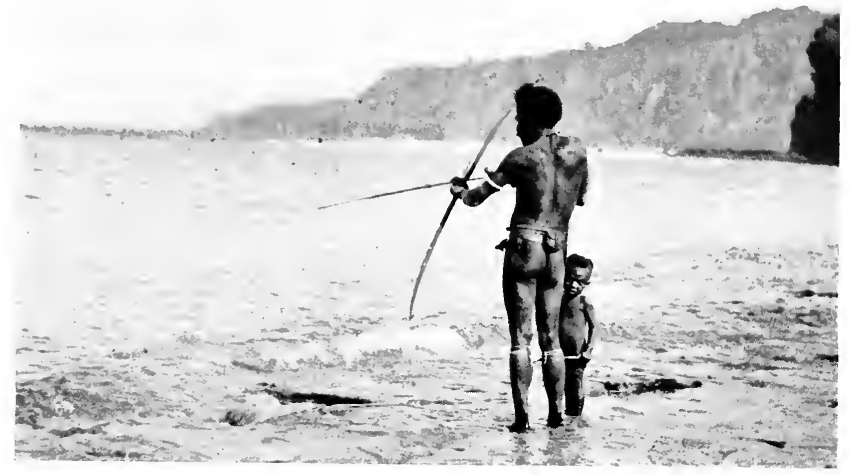

SHOOTING FISH

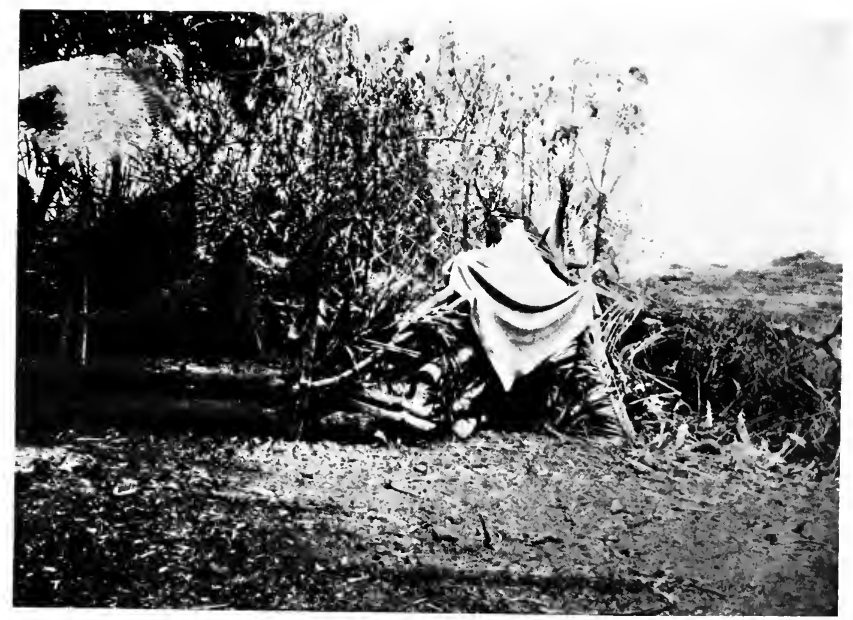

NIGHT REFUGE 
(UERARP 
through it. The rest of the costume consists merely of a leaf or two. The women wear a short kilt of dried grasses, made full and spreading, and rather suggestive of an emu's tail at the back. Both sexes are generally ornamented with rows of parallel scars, or lines of raised dots, made with the knife. The men are generally heavily bearded, and strongly built; the women are of fair size, and occasionally rather passable in looks. They are a cheerful-looking race and quite devoid of the sulky, hang-dog look that disfigures most other New Hebrideans. Indeed, the Tannese, when not actively engaged in murder or cannibalism, is not at all a bad sort of fellow. He is an excellent sailor, and a splendid boatman, always cheerful, if well fed, decently treated, and always ready for an extra spurt of work, on any special occasion. Like the Fijians, who were at one time the fiercest and most brutal cannibals of the Pacific, and who are now a peaceful and respecting nation worthy of the Crown that owns them, the Tannese will in all probability "train on" into a really fine race, as soon as they can be restrained from continually murdering each other on the slightest provocation, and induced to clean their houses and themselves, and live decently and quietly.

A day or two after my arrival I got a native guide and walked to Lamanian, a village some three miles up in the bush, with the view of seeing something of the fighting country. About Lenakil the tribes are always at war, and a perfect reign of terror prevails among the natives. The Tannaman dare not sleep in his village by night, for fear of sudden surprise. After dark he creeps out to the bush, and hides himself in a hole or a gully till the morning. In the still, moonless hours he may wake with a start, and hear a stealthy footstep padding through the reeds close beside him, and to feel 
the thud of a rifle-stock struck down on the earth within a yard of his hiding-place, in the hope of discovering where he lies. The foot passes on-he is safe-but he cannot sleep now; he must get up, and creep with painful care through the scrub and the reeds to some yet lonelier, yet more secret, spot. Is that the dawn at last, spreading in faintest water-gray through the stems of the reeds? It is-he must rise, shivering and weary, and hurry home to the shelter of the village, before daylight surprises him out alone in the bush, where every tree may hide a murderer. And as he goes he keeps his rifle over his shoulder, ready cocked and loaded, for he knows that the enemies he fears fear him equally, and to-morrow night he himself may be crawling on all fours about the stockade of some hostile village, or gliding through the bush on the other side of the bay, stalking just as he has been stalked. Such is the Tannaman's life in these days.

On the way up to Lamanian we passed a good many yam gardens, but only in one was any one working. Here we found a few women digging and scraping under the guard of two or three armed men. The women nearly all had blackened faces-the Tannese sign of mourning. The yam garden was a waste of parched and powdery earth; the bush around was burned yellow and brown; the pale sky above quivered with the fierce midday heat. Stolid, ugly, and streaming with sweat, the women worked dully on, breaking off for a few minutes to stare and wonder at the visitor, and then continued their heavy task. It was a weariful picture.

About the approach to the village the scrub had been extensively cleared away, to prevent ambush. The high, plaited-reed fence that surrounded the huts was something of a safeguard, slight though it was, since it could not easily be seen through by wandering sharp- 


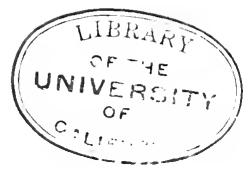




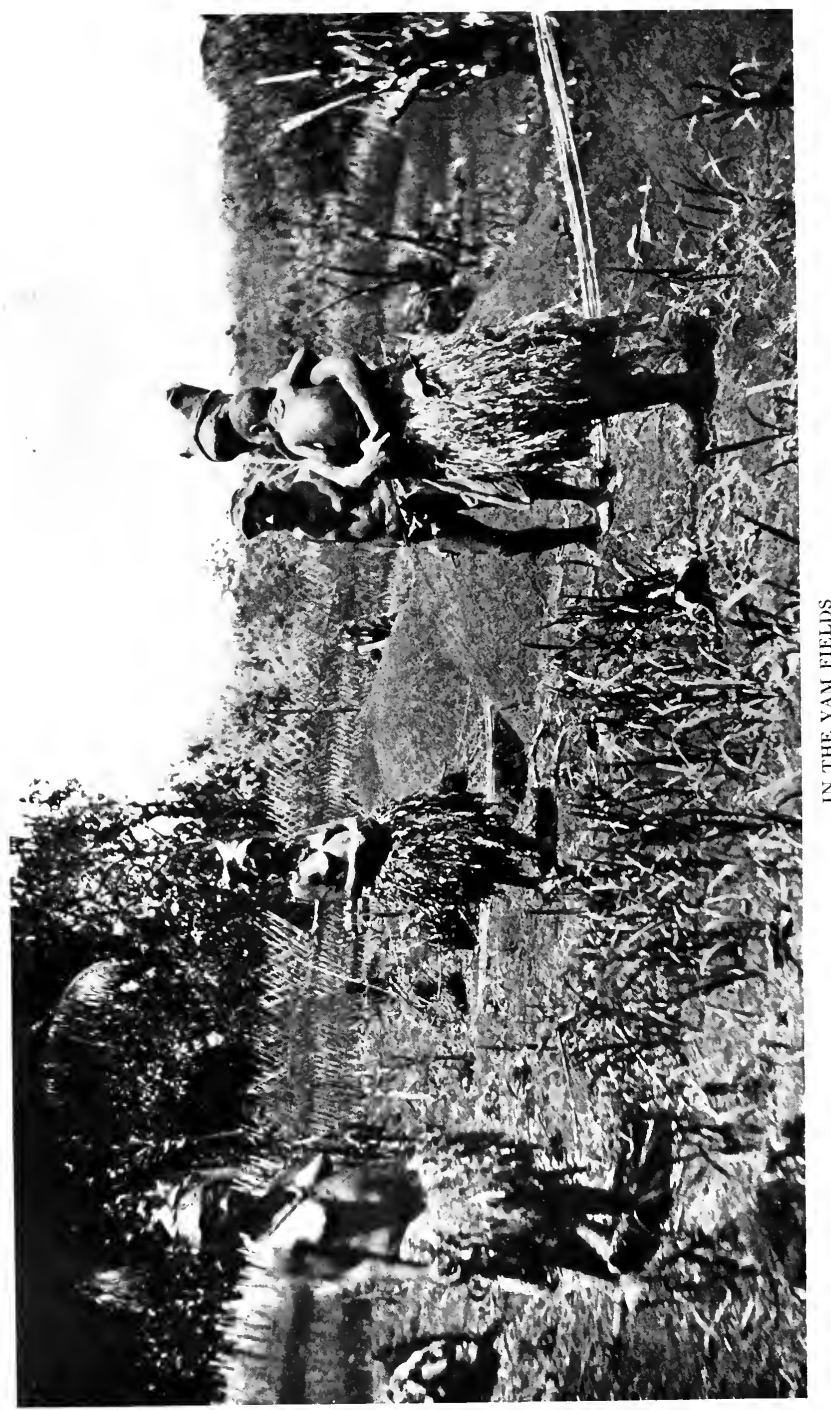


shooters. My native guide told me that it was sometimes supplemented by a portable bullet-proof fence, a few yards in circumference, inside which the women sat and did their cookery.

The village itself was an ugly collection of low ramshackle huts, built of reeds and thatch. Its one beauty was the great banyan-tree, which is never absent from a Tannese town. Just at the entrance a tobacco-pouch, a water-bottle, and a cartridge-case were hung on a banana-tree, silent memorials of the last man who had been killed by the opposing tribe. Most of the Lamanian men were away, stalking the enemy through the bush and reeds of the hills, but two or three, armed as usual, were left to stand guard over the women.

There were some odd things hung up in the banyantree-strange-shaped roots, fungi, neat little bundles of sticks tied up like firewood. I was told that the last were records or tallies of the biggest spiders' cocoons that had been found! When a Tannaman finds a spider's cocoon he counts the eggs, and registers the number with a bundle of sticks, one for each egg. It is his ambition to "go one better" than the next village in the score thus obtained. The other objects were simply curiosities. The banyan, in fact, is the village museum. I could not find that there was any religious association connected with these curious attempts at "nature study"; they seemed to be entirely scientific. More purely utilitarian was the oddly shaped box. I noticed in the middle of the village - explained as follows by my pigeonEnglish-speaking guide:

"One time Lamanian man he keep a bee there; now I think the bee he clear out!"

Another day I went up to Imale, where there was rumour of serious fighting. It was thought that an 
attack - or something as near to an attack as the Tannese ever make-would be made on this place in the course of the day, for the Lowinnie men, who were hostile, knew that a meeting of two tribes was to be held at Imale that morning, and it was probable that they would try to take advantage of the occasion. My host, the missionary of the district, went with me. We carried no arms, as there may be risk in doing so in Tanna, and there cannot be much protection. As in Malekula, absence of firearms at once proclaims the peacefulness of the visitor's errand, so that he can approach a fighting village safely, as a general rule. If the natives had any grudge against him, and wished to kill him, he would be shot from ambush in the back, so that firearms, even if carried, would not be much use.

The walk up from the beach where we left our boat to the hill village of Imale was exceedingly hot, as there was a very steep rise, and no air circulated through the tremendous reeds-over fifteen feet high-that shut in the track. Every here and there these were cut away so as to give a clear view ahead, and prevent surprise from any one creeping softly along the open path round a corner. We advanced quickly and rather noisily to the village, and found a score or two of men sitting about the square, nursing their guns. Right across the centre of the open space lay an immense branch, cut down from the great banyan overhead-a sign of vengeance and a call for blood. The chief of the village had been killed by the enemy, and this bough had been cast across the village square to symbolise his fall, and act as a continual reminder. To-day it was to be burned, for a friendly tribe from the other side of the bay had killed the slayer of the chief, and his spirit was avenged. A dozen or two of this tribe had slipped away at dead of 


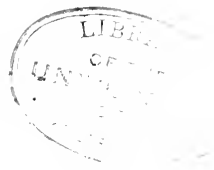




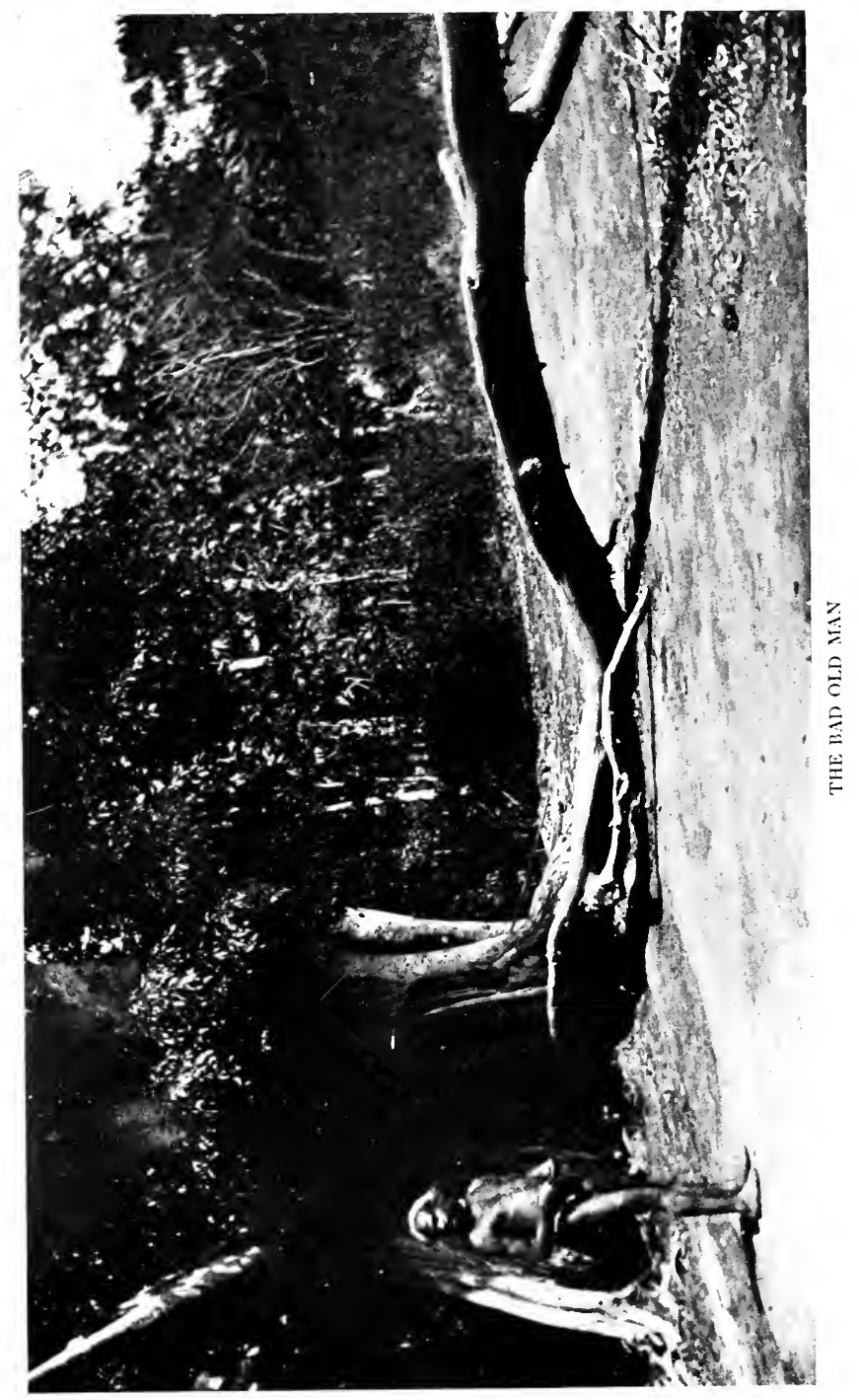


night in their boat. and come up to Imale in the dark. They were now going to receive their reward from the new chief of the village, who was the brother of the man that had been slain.

No objection was made to our presence, and while the missionary engaged in a little conversation with a man he was hoping eventually to convert from heathenism, I roamed about the square, photographing and talking. I was not understood, but I did not understand the replies I received either, so things were even.

There was a good deal of military science, in a small way, about the disposition of the fighting men. The women they had placed in an enclosure behind a high reed fence. Some of their own number were perched in high trees overlooking the approaches to the village; others were squatted down on their heels, gun in hand, at the two entrances. The rest sat or lay about the village, keeping an intermittent lookout while they talked, or stared at us with a kind of sullen curiosity.

I was sitting on the fallen banyan log, and watching the villagers set fire to the far end of it, when two or three men came hurriedly into the square, and rushed up to an ugly old chief, who seemed to have quite as much influence as the titular head of the village. They carried a small green parcel, wrapped in banana leaf and neatly tied with native fibre. Everybody wanted to see it at once; all heads were bent over it, and all eyes strained, while the old man untied the parcel, and disclosed-a lump of fresh yam!

The celebrated footprint in "Robinson Crusoe" could not have caused more excitement. To whom did the yam belong? Whence had it come? How had it been dropped where it was found, right in the middle of a track leading up to the village? No one 
knew anything about it. It seemed obvious that "an enemy had done this thing," and an enemy who must be unpleasantly near to the village at that minute.

Nothing could be done; so, after a good deal of chatter, the old man merely told his followers to keep a good lookout, and went on with his conversation, which chiefly concerned the disposal of an enemy's body supposed to have been partly eaten by him a few days before. The missionary and I both wanted to know about it-he because he wished to discourage this sort of festivity; I because I wanted to get a thigh-bone as a curiosity. It could not have hurt the gentleman who had been made a roti of, and it would have been very useful to me. But the old chief was "foxing"; he had never heard of cannibalism, not he; the man hadn't been eaten at all-he wasn't even sure that he had been killed.

Such an innocent, amiable old man as he looked! Such a simple, child-like smile as he put on! His gray hair, tied up in a red and white pocket-handkerchief, looked wonderfully venerable and reverend, and he himself everything that was respectable-an impression hardly detracted from by the circumstance that he wore no other clothes save the head-dress referred to. And yet-his fox-like old eye, shifting and twinkling under those pent-house brows.

"Now, look here, you know you did!" says the missionary plumply.

The nice old gentleman's smile takes on a different character-becomes, in fact, a giggle, like that of a schoolgirl caught eating surreptitious chocolates.

"Well-I eatum jus' little-fellow bit?" he allows.

At this naive admission (based on a model that most people will recall) I cannot help laughing irreverently; 


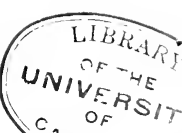



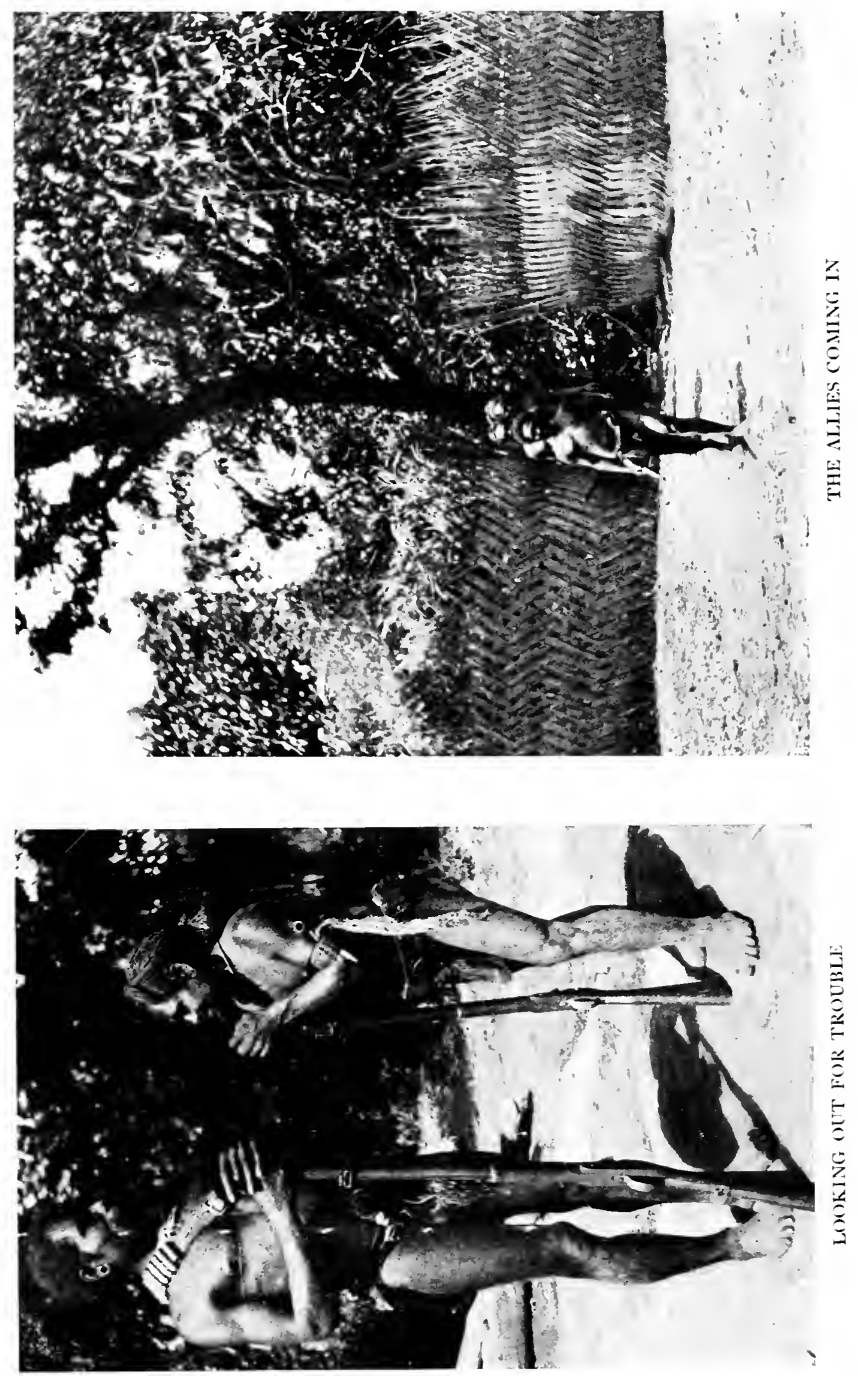
and just at that moment, as Rider Haggard would say, "a strange thing happens." The fifteen warriors squatting at the other side of the square suddenly rise as one man to their feet, and point their guns straight at us. We are, in fact, in the position of a couple of deserters facing a firing-party. There might be pleasanter positions.

"Stop that!" yells the missionary in Tannese; and the natives lower their guns, looking a trifle astonished. The old chief explains. It is quite a simple explanation as he puts it-they saw a head moving some way behind us in the scrub, so they were going to fire at it; that is all. The circumstance of our heads-and bodies-being equally in the line of fire is evidently not regarded as pertinent to the matter in hand.

Was it an accident, or what schoolboys call an "accidental-done-on-purpose?" We never knew. The New Hebridean mind is what Lewis Carroll would call "scroobious and wily"-and no white man can follow its turnings. It is quite capable of planning to kill you, for no conceivable reason, and abandoning the plan, also without reason, and in a minute. All that one can be certain of about a New Hebridean is that there is no certainty in him.

It is now time for the pigs and kava, and a loud grunting and scuffling forthwith arises behind the scenes. The visitors are to be paid for the death of the enemy they killed; and the payment takes the form of four fine large black pigs, and a great heap of the root out of which the Tannaman's favourite drink is concocted.

These are brought in in stately procession. The pigs are then knocked on the head with clubs, and give up the ghost without a struggle, though they look ugly enough afterward, lying there in a blood-stained heap. The recipients would rather have had them alive, but 
custom prescribes that this blood-money must be given literally stained with blood.

And now, relaxing their keen watch a little-for no sufficient reason, since the enemy are just as likely to be about now as they were half an hour ago-the men begin to make speeches, and talk over the events that led up to the murder for which they have just been paid. One of the visiting tribe gets up, and walks backward and forward, talking and gesticulating excitedly.

He seems to take turns with the old chief, who walks out and back to meet him from the other side, talking too. They are very like the figures in a fine-weather mantelpiece toy-one out, the other in. A native who speaks some English translates. It seems that between them they are going back over the local history of the last two or three years, registering every kill on one side or the other, and working themselves up by enlarging on their wrongs.

It is warmer than ever now; the bare dusty square is simmering in the sun, and the sky is almost white with heat. Even the naked Tannamen feel it; they crowd together under the shade of the big banyantree, turning their bushy, bearded heads and wild, fierce eyes as one man toward the speaker of the moment. Stray lances of the stabbing sunlight touch the bandoliers of cartridges that they wear, making a faint twinkle on the dull brass and rusty buckles, and glancing off upon the long barrels of the guns, that move and shake in the shadow like ranks of tall, steel reeds. Above, in the immense aerial forest of the banyan boughs, a mighty swarm of locusts screams and chirrs ceaselessly.

If one were lying ill of fever in one of those wretched, sun-smitten huts, how fast that torturing chorus would drive one to suicide or madness! . . . 
And still the speeches go on.

"When will they stop?" I ask.

"There's no knowing. It may go on all day. The other tribe will probably not dare to go home before dark."

"Then I suppose we may as well go ourselves." And we went.

Down on the beach, the boat's crew were busy loading wood, so I wandered off to see the refuges that the people of Imale had been making use of at night. Here and there, hidden among the pandanus and hibiscus scrub close to the shore, I came upon low shelters of plaited palm-leaves, laid against rude rough fences of reed and leaf, meant to hide the faint glow of a cookingpit-baskets of food hung upon trees; old blankets lying in the sun at the mouth of some dark cave. These are the places where the unfortunate villagers hide themselves after dark. An enemy may creep into a village square at night, slip his rifle barrel inside a hut, and kill the sleepers; but he can hardly hunt the whole bush for his quarry. So the people of the hills hide themselves near the shore at night, miles away from their own houses, and return at break of day.

Not long after, I had a chance of seeing the Lowinnie tribe, the very one whose approach had been feared by the folk of Imale.

From the house where I was staying, I saw a long string of bush people winding in single file down toward the sea. I followed them, armed with my camera, and found them down on the beach, the men standing about with cocked and loaded guns, guarding the women as they bathed in the sea. More than one woman of this tribe had lately been shot, so they were especially careful of the rest, for women are valuable property in Tanna, worth several pigs apiece. 
It was a bright and vivid scene-the intense white sun beating on the snowy beach of broken coral, the brilliant green vines trailing across the strand, the burning blue sea, shading into clear apple-green close to shore; the wild brown faces, and gleaming smiles of the women, excited by the importance of their armed bodyguard. They wore the usual small fringe of grass about the hips; they had rubbed their bodies well with cocoanut oil, and their brown skins shone with unwonted sleekness and cleanness, as they came dripping out of the warm green waves. Most of them were shy of the camera, and fled with frightened cries; others, when begged to stay, stood their ground for a minute, trembling and laughing. There was no lingering to enjoy the pleasures of the bath. As soon as all were out the column formed up once more -armed men as advance and rear guards, women in the middle, scouts scattered out to the left. I walked along on the right for some way, watching the demeanour of the scouts to the other side. They kept a sharp lookout to the left, and carried their guns on their shoulders, ready for immediate use. The worst of their enemies lived over in that direction, and, as there was plenty of cover, it was feared that they might do some sharpshooting, taking advantage of the large number available for aim. There was no firing, however, and the column wound off up to the hills in safety.

"Netik" is more or less at the bottom of the tribal fights in Tanna. It is, briefly, a belief in the power of one man to kill another by witchcraft. The Tannaman firmly believes that if an enemy can obtain a lock of his hair, a nail-paring, a bit of clothing, a scrap of half-eaten food or half-smoked tobacco, he can with the fragment make a spell that will cause the death of the owner. Further, he keeps a constant lookout for oddly shaped 


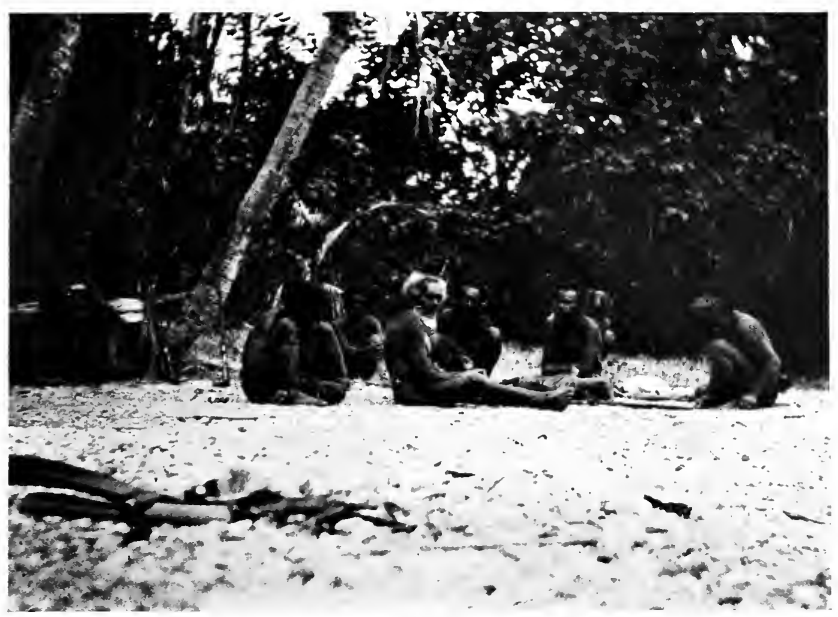

THE COUNCIL OF WAR-THE SPEAKER FOR WAR

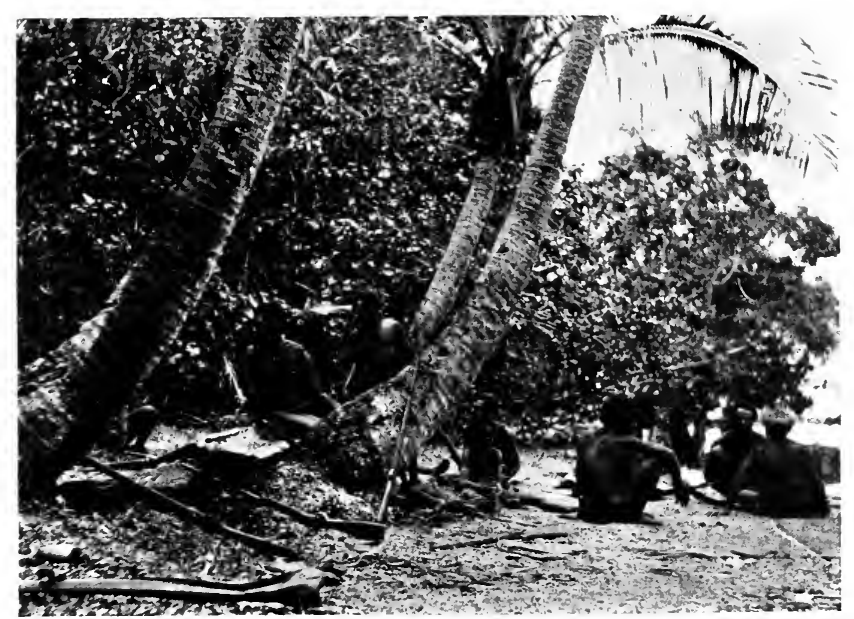

THE COUNCIL OF WAR- WHAT WAS THAT?" 


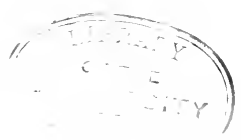


stones of all kinds, and when he finds something resembling any part of the human body, he secures it at once, makes offerings of food to it, and endeavours to obtain the favour of the spirits through it, so that the corresponding part of his enemy may waste away through disease. If any Tannaman, therefore, suffers from disease of any kind, he looks about for a man who may be supposed to have some "netik" stone in his possession, or to have obtained something belonging to the sufferer. Sometimes the deed is actually claimed by an enemy anxious to obtain credit for himself or to alarm others. Sometimes an innocent person is fixed on as the cause. In either case, there is trouble, and probably murder, to follow. Every death, from any cause, is also put down to "netik," and demands revenge as much as an open murder. A continuous vendetta is thus created, and fighting is never quite relinquished, at the best of times. It would indeed be hard to say why it should ever cease, under such circumstances.

At times there is some desire for peace manifested, but it never comes to anything. During my stay at Lenakil, a number of fighting men were seen one day to be assembling on the shore below the house. This is rather an unusual spectacle, so the missionary and myself hurried down to see what was going on. It proved to be a council of war. A number of the most influential men from several different tribes had met to discuss the fighting, and see if something could not be done toward arranging a truce. For several hours they talked, down on the blazing shore, in the slight shelter of a clump of young palms, the speaker of the moment standing, or pacing up and down, the listeners squatting on the sand. The missionary joined in at times, and tried to persuade them to come to some 
agreement, but they did not pay much attention to him. As for myself and my camera, they did not trouble about either at all; a woman, in council of war being obviously a negligible quantity.

One chief-an cld and very evil-looking personaddressed the house frequently and fluently in favour of war. Another, who was young, heavily bearded, and of a rather pleasant countenance, spoke in favour of peace-so the missionary, who understood the language, informed me. One could almost have guessed the subject of the discourse unaided, however, from the demeanour and features of the speakers-in one case, mild and temperate, in the other, fierce, eager, and excited. They remained on the beach talking the greater part of the afternoon, and when they separated at last, the speaker for peace had evidently been defeated, and the advocate of war had won the day.

If the tribes could be disarmed, and the sale of rifles stopped, fighting would probably cease, for the Tannaman cannot murder from ambush with a club, and he has not much taste for open warfare. But the law that prohibits the selling of firearms by English traders in the New Hebrides is a dead letter, and the French do not attempt to check the sale at all. The dual interest in the group, and the absence of definite ownership, prevent the taking of any strong action on either side, and so the loss of native life and injury to property goes on unchecked.

No white man has been killed on Tanna for several years.

It cannot be long, however, before the reckless shooting of the Tannamen brings about another case. Not to mention any other instances, myself and the local missionary certainly came near to furnishing an example 

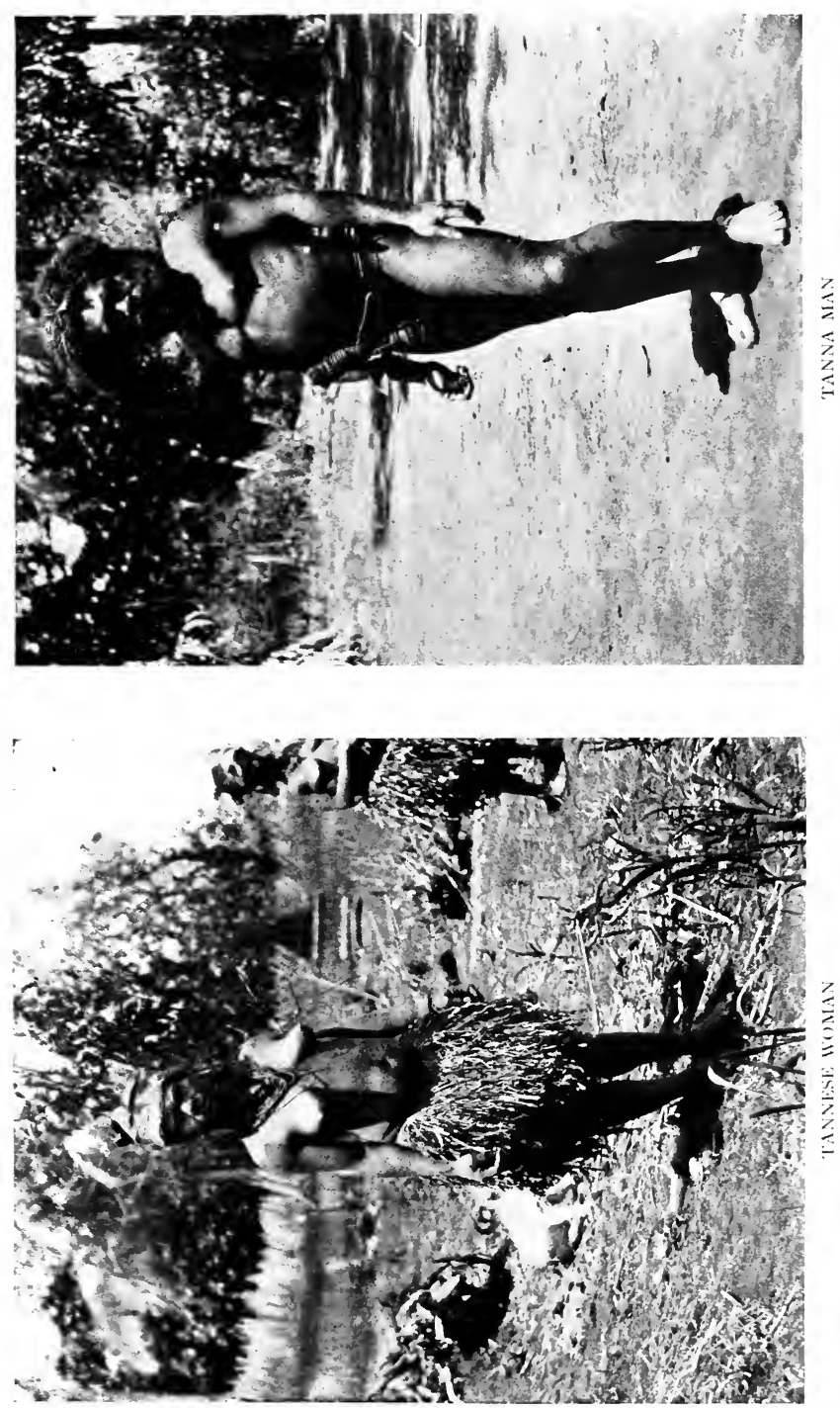


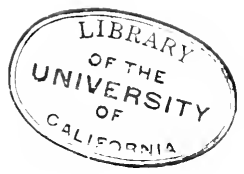


in the village of Imale. I do not attempt to point any moral. There is no use in saying that the ownership of the islands ought to be settled and the natives compelled to disarm because, at the present showing, the New Hebrides tangle does not seem likely to untangle itself before the trump of doom. Nor is there any sense in blaming the traders. They cannot afford to give up the sale of arms and ammunition singly, since it would be merely casting trade into the hands of the nearest rival, and depriving themselves of even legitimate custom. If the sale of arms could be simultaneously stopped all over the islands, most of the traders would be glad, as their profits from coprawhich depends on peaceful times for its productionwould at once go up. But no one can afford to stand out, and there are a good many who would keep no agreement in any case. The problem is one that may best be left to those who are responsible for its existence.

While I was staying at Lenakil I happened to see a particularly impressive sample of the work done in Tanna by British-made and British-sold bullets. Away in the hills a woman had been badly shot, not by accident, as one might suppose; men, women, and children are all the same to the Tannaman on murder bent. My host, the medical missionary of the district, was visiting the bush villages in that part. and decided to take the chance of bringing the woman down to his hospital, as it was certain that she would die where she was. She was tied on a stretcher, and carried by the natives over nine miles of almost pathless mountain, bush, and gully, afterward journeying twenty miles in an open boat. Next day the doctor decided to operate, and when half-way through his work sent for me to come in and see the case, as it was rather singular. 
I crossed over the sunny lawn to the hospital building, and entered the tiny white operating-ward. There the woman lay on the table, her breast straining audibly in the long mechanical heave of chloroformed respiration, her deep-lashed eyes shut, her pretty little hands hanging limp and lifeless over the table edge. She was a young, attractive, very feminine-looking creature; and the ghastly rift that disfigured her delicate side seemed all the more anomalous and horrible. No modern Mauser or Lee-Metford bullet could have inflicted such a wound; only a shell could have paralleled it. Three ribs were splintered, and two of them driven into the lung, wounding it seriously. The liver had been ruptured by the shock of the bullet, and protruded through the opening, a ghastly, gangrenous mass. She had already lived ten days in this terrible state, so there was a faint chance that she might survive, but the doctor had not very much hope.

As no assistance was needed, I left the doctor and his wife and native helper to their work, and came out in the sunshine again, hearing still the laboured heave of the struggling lungs, and seeing the poor pretty girl upon the table, torn with such wounds as only a soldier should ever have to face, and that for the safety of his country alone. I thought of one other woman up in the hills, who had died not long before, after living more than a week with all her face shot away; of the many men going about with crippled and shattered limbs; of the twenty corpses, some buried, some eaten, that had been living human creatures only a few weeks before; of the reign of terror in the bush villages, and the "peril that walked in darkness," night by night, the island through. And I wished, most earnestly, that I could see the strong hand of Great Britain or her Colonies 
grasp the bridle of this wretched country, as unfit to be left to its own guidance as any runaway horse, and pull it firmly and determinedly into the road of civilisation and law-abiding peace. The missionaries have done what they can; but the hand of a strong government could do very much more. Disarmed by force, as the Solomons have been, held in check by able police and magistrates, like the Fiji Islands, the New Hebrides could in time be made a useful and valuable country, populated by industrious, peaceful natives. As things are, however, there is little hope. Australia, to whom the islands should rightly look for their preservation, will have none of them. Franceconspicuously unsuccessful with every Pacific colony she has ever owned-is anxious to take them, rightly or wrongly. Great Britain will not let either have them, and will not take them herself. So the tangle drags on, and the reign of terror continues unabated. 



\section{CHAPTER XV}

\section{TANNA-ITS SCENERY AND RESOURCES}

Somebody's Picnic-The Simple Life in Tanna-The Returned Labour Trouble-Up the Great VolcanoThe Valley of Fire

FTER a stay of a week or two at Lenakil, I rode
over to Whitesands, some twenty miles away, on the other side of the island, to see the volcano. The track lay through the bush and over a chain of hills, and crossed most of the fighting country. I took a native guide, who could speak a little English, and started early in the morning. Bush fires, mostly of malicious origin, had been extremely prevalent during the past few weeks, and I was rather uneasy to see half-burned trees and smoking ashy slopes on our left as we passed up a precipitous gully.

"What shall we do if bush fire come along, Simoni?" I asked, vaguely recollecting "adventure" tales I had read long ago, in which Australian and American people, threatened by fires, had set fire themselves to something or other, which somehow burned, and protected them from the other fire-I did not exactly remember how.

"Not do nothing," said Simoni cheerfully. "Cook all-a same pig!"

I was quite sure that this was not the last possible word on the matter, and I rather wished I could conjure an Australian out of the banyan trunks in front; 
because, according to the books, Australians are always equal to dealing with fires and floods, and runaway herds of cattle, and anything else that may occur upon the King's highway to agitate a sensitive female, and cause her to wish herself safe inside a Pullman car with the blinds down. It was true that all the Australians I had happened to see in their native lairs had been engaged in buying and selling more or less "alleged" gold-mines, inside a palatial office; writing leading articles at dignified leather desks, or discussing the virtues of different brands of wine, under the glow of shaded electric lamps, at a luxurious dinner-table. This did not shake my faith, however, because I knew that they were merely playing at that kind of thing, and that they all had gone, or would go, or would like to go, ranching and clearing and bush-whacking (I do not know the correct translation of the latter word, but it sounds satisfying, somehow), at the first opportunity. If not, the books must be wrong, which is absurd, because nothing British is ever wrong; and therefore, if an Australian-any Australian-had dropped from heaven at that moment, he would, like "Epps's cocoa," have been extremely grateful and comforting. Q. E. D.

As it turned out, there were no more bush fires, and I forgot all about them in half an hour, since it became necessary to take my horse out for a walk on a string, like a pet spaniel, every now and then, for half an hour or so, during which time I scrambled like a cockroach (only without its invaluable complement of extra legs) up and down places that were never meant for the passage of anything unprovided with wings. On a fine windy tableland, some 800 feet high, we came to a halt at last, and Simoni got out the lunch sack, and there was billy, 


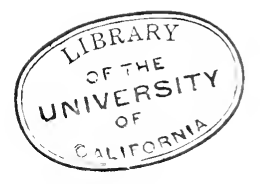




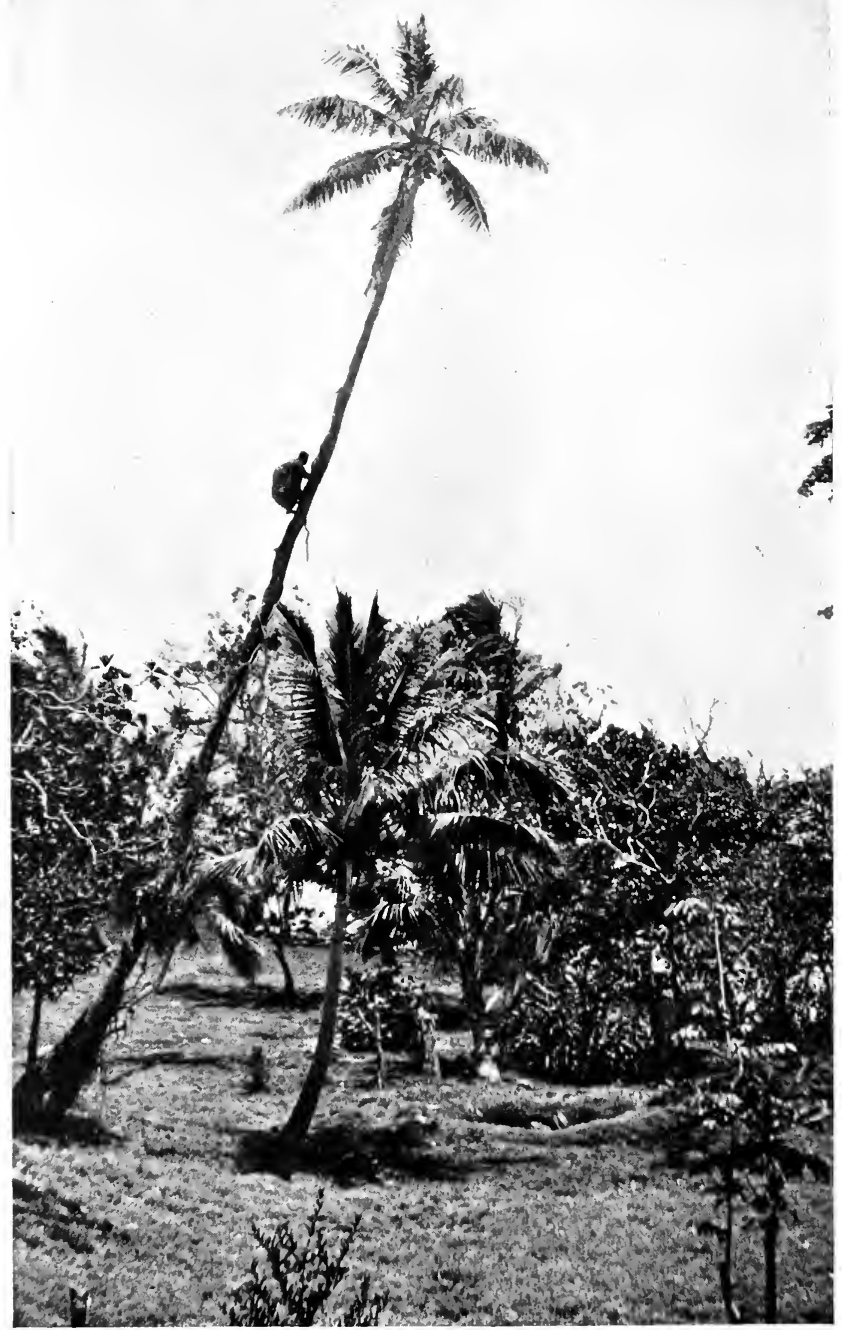

TANNESE GIRL CLIMBING A COCOANUT PALM 
tea, and bread and sardines thereto, and much refreshment. There was a magnificent view from this pointalmost all of Tanna lying like a bright-green map under our feet, with the great volcano standing up by itself in the middle of a gray level plain, and the islands of Aniwa and Erromanga floating on the blue horizon, far away. And there was a pleasant little grove of trees to break the force of the beating sun, and more than one soft bank of bullock-grass to sit on, and rest. . . . A very pleasant place for lunch, it semed to me.

I did not know. . . . but that comes by-and-by.

More cockroach scrambling, down outrageous heights, with the horse doing the chute business behind me as if he had been brought up in a circus; more glaring sun; more choking, drought-bred dust rising in cloudsand now, half-way down to the plain, a sudden sound arrests me. It is rather like thunder, but it is not thunder; it suggests an earthquake, but the palm-tree plumes are steady against the burning sky. It is, perhaps, most of all like the low, threatening growl of a vicious dog, magnified a million times; but it does not really resemble any sound I have ever heard before in my life.

Simoni points triumphantly to the smoking cone some eight miles away.

"That the fire place; hear um sing out!" he says. "By-n-by, hear um plenty smell!"

We are just beginning to "hear um smell," a mile or two further on, upon a windy plain distinctly perfumed with sulphurous odours, when Simoni-suddenly overcome by reminiscences that, like the flowers of spring, "have nothing do do with the case"-bursts out laughing.

"You savvy that-fellow place you eat 'um dinner?" he asks chucklingly. 
"Yes; what about it?"

"All same place, Tannaman he eat woman, leg you got in one-fellow box; two, three, four week!" Simoni cackles explosively.

This requires explanation. Some little while before a native woman had been eaten by the iribes above Lenakil, and the missionary, I do not know how, had obtained possession of some of the relics of the victim. He had given me a thigh-bone, which I wanted to keep as a memento of Tanna-rather a ghastly souvenir, it must be confessed-and this bone I had packed away in my box. Simoni knew all about it, and had prepared the little surprise about the picnic-ground as a good joke. . . . Now I came to think of it, it was certainly he who selected the stopping-place. . . . A nice spot for a picnic, truly.

There were very few natives about here, and those we met seemed to be exceedingly alarmed, I really do not know why, unless it was at the horse, since they are still very unfamiliar with horses in Tanna. One or two ran howling up the nearest palm-tree when they saw me, and continued to climb, looking down and howling ceaselessly, until I was well out of the way. It was evident that they were not at all sure I could not, and would not, ride up after them!

After the field of the cannibal feast was left behind, and the view of the volcano had disappeared in a jumble of trees, we went on and on for a good many miles through a pleasant up-and-down valley, the path a mere crack in the thickness of the bush as a rule, but now and then showing the loveliest glimpses of distant green-bluegreen, smoke-green, gold-green-always green, and always foliage, tight-packed as a pin-cushion. There seemed to be nothing left on earth but tree-trunks and tree-tops. 
The ravaging hand of the utilitarian white man has not so much as scratched Tanna as yet. If you want to go to any place where the natives do not naturally go, you will have to do it as Stanley did the forests of Central Africa-with an axe and unlimited patience, at a couple of miles a day-and your road will close up behind you almost as fast as you make it.

It was hot, with the soaking, head-hammering heat of the New Hebrides in December; but there were certain alleviations on the way. Not to speak of the priceless green cocoanut, heaven's best gift to travellers in the tropics, there were rose-apples in rare places, all waxypink without and waxy-white within, and delicately flavoured with otto-of-rose. And here were fat sticky little figs, and great yellow clusters of tree-melons, miscalled mummy-apples, and somebody's pine-apples -he will never miss what I stole-and odd, nameless orange-coloured capsules, enclosing sweet red seeds. I stopped to levy tribute as we went along, because, if one has got to work between meals (an unwholesome habit at best), it is as well to make the meals as many as possible.

It was a journey to break the heart of any one connected with the copra trade. I wished that I had had someone from a soap-making firm with me, to enjoy his agonies at the sight of the wasted shiploads that cumbered the ground in every direction. This part of Tanna is a veritable gold-mine of copra. For miles and miles of untouched forest the cocoanuts spread their rustling fans to the hot sky; the pillared trunks stand thick as cornstalks in a field; the huge brown nuts lie scattered in rotting heaps, sending out feeble little shoots that are certain to die ere long for want of air and sun.

Where the well-worn bush tracks cut through the 
forest the Tannaman sometimes bestirs himself so far as to collect a few nuts from the edges of the path, and split and dry them, so that he may be able to buy tobacco from the trader, and a knife, and beads for his women, and a leather belt and pouch, and huge blunt-nosed cartridges for the old Tower rifle that he uses to settle his disputes with the next-door neighbour. But anything more than this he will not trouble to do. What is it to him that the earth for miles is rotten with white nut-meat that could be transmuted into every luxury of civilisation? He does not want clothes-he informs the inquiring traveller, with beautiful candour, that there is nothing wrong or deformed about him, to be covered up, and that he would die with shame to be seen in a shirt or a sulu! He has no wish for a wooden house with a tin roof, when he can exist happily in a pig-pen that consists simply of a roof and nothing else. Why (he asks) bother with walls and posts when you can lay your roof right on Mother Earth, and thereby reduce all the problems of housing to one simplecommon denominator (or words to that effect)? Tinned meat and "samani" are good, but they may be too dearly bought, and, besides, in Tanna there are occasional "excellent substitutes for the more expensive article," of which the coy bushman does not care to discourse. No, on the whole, the Tannaman prefers to leave his "magnificent, natural resources" undeveloped, and thank you kindly, sir.

He will not let you take a hand in the business either. He has grown suspicious of white men and their motives of late years, and although the letting of his land may be all for his good, "Tommy Tanna" says, in effect, that he does not care a bad word about his good, and will be obliged to you to keep your fingers out of his cocoanut pie, and return to the arms of the steamer company, for 
he does not want you, or the like of you, to play in his backyard. . . . So the copra country goes to waste and the very few traders who still maintain a footing in Tanna do not find that the seams of their garments need frequent letting out. And the Tannaman shoots his neighbour frequently, and eats of him frugally now and then; and under his dirty roof-tree lives the "simple life" with his simple pigs and wives undisturbed.

Everything comes to an end, even a bush ride, with walking obligato (which means walking when you are obliged) across Tanna; and at last, having ridden "from sea to sea," I and my guide (it is not grammar, but racial pride is above grammar any day-and the guide was black) arrived at the hospitable mission station in Whitesands Bay, where I had been asked to stay a week or two.

Mission stations, in the New Hebrides, occupy much the same position as the monastery of the Middle Ages did in England. They are almost the only centres of light and learning in the midst of surrounding darkness; the inhabitants act as guides and governors to all the neighbourhood, and their hospitality is the traveller's only refuge from camping with the land-crabs and mosquitoes on the "coral strand."

Like the ancient monastery, also, they are very comfortable places indeed, full of good cheer and simple luxury, and the traveller who experiences their generous hospitality may be very sure that he will be well treated. There will be a big, cool house, with a good veranda and handsome imported furniture; there will be a flock of goats, a sheep or two, to provide milk and meat; there will be another flock of servants, black but willing; horses, boats, shower-baths, pretty drawing-rooms, bright flower gardens - all in the midst of a wilderness of savages 
and cannibals, and dirty, miserable native villages. Truly, an oasis in the desert is a New Hebridean missionhouse.

Sulphur Bay was peaceful enough while I was there, but so much could hardly be said for the mountain interior. Only a few days after my arrival the word went forth from the chiefs of the hill country that they did not choose the white man should cross the island, and that the path I had lately come by was to be closed by a "taboo." It was also reported that bullets had been flying on the said path, and that a native had nearly been hit.

My missionary host thereupon arose, and said that such things could not be tolerated, and that he would go up into the hills and see about it. I petitioned to go too, and was allowed. We started off in the early morning afoot, as the tracks were too bad for a horse. We tramped thirteen miles, with perhaps half a mile of level ground in the lot, and had intended to tramp almost as much more, only that the chiefs happened to be down from their towns that day, and information was to be had more cheaply by questioning one of them on the spot.

It was not very satisfactory. We were told that the proclamation was really a mistake-that no one wanted to do anyone any harm, and that nothing had happened. Questioned further, the men of the mountain allowed that they didn't want a certain tribe to use that path, because the said tribe was at war with themselves. They might have said something-there might have been a bullet or so-but there was no harm meant. . . . It seemed a hollow explanation; but it was all we could get.

To my mind it was suggestive, and not pleasantly 
so. Tanna is getting out of hand; straws show the way the wind is beginning to blow in more than one quarter. The bush tribes are absolutely reckless as to the destruction of white men's property when they start out to burn each other's gardens or villageswith the consequences that I mentioned earlier. They are also quite careless as to any danger that may result to white people from their very free shooting. It is only the small number of the whites in Tanna that have, so far, prevented the occurrence of any accident from this cause. Bush tribes who are at war will carry on their little disputes, Tanna fashion, by means of separate murders, right round the mission-houses and trading-stations, so that one never knows, when staying in the island, whether a stray shot that sounds through the cool sunset air, as one sits drinking afterdinner coffee on the veranda, means a flying-fox justly executed for orange-stealing or a murdered human being.

"Tommy Tanna," furthermore, as he comes home from Queensland, makes more and more trouble in the island. The Queensland Tannaman is notoriously the worst sort in Tanna, always at the head of tribal fights, usually among those most strongly opposed to the mission, and generally disposed to make as much trouble as possible. The reason is simple enough. He has been years away, his land is overgrown, his painfully amassed pigs are eaten, his house is a ruin, his yam plantations desolate-if, indeed, some greedy neighbour has not actually annexed all his property. The money he brought from Queensland is squandered in a day, native fashion, and the Tannaman becomes a poverty-stricken wanderer, full of restlessness and discontent, and finding no outlet save that of making 
trouble. Therefore he makes it, industriously, as a profession and a sport at the same time; and the island, in consequence, seethes with discontent and disquiet.

With Tommy Tanna of Queensland-full of civilisation's vices, sharper and more knowing than his fellows, yet a savage to the tips of his fingers-joins in the conservative party of the island, the older chiefs, who hate the white man and all his doings, and the younger and more savage savages, who are beginning to take alarm at the increasing power of the missions. For two generations the missionaries did almost nothing in Tanna. Now their work is beginning to take effect and converts are coming in. This is alarming and angering the opposition; and, backed up by the Queenslander Tannese, they are beginning to talk in an unpleasantly significant way. The Queensland labourer has, after all, learned something during his foreign travels; and the cry that he is now spreading about the island is: "Tanna for the Tannese!"

"If the white man won't have us in his country we won't have him in ours," declare the Tannamen. And they are not talking idly.

There is but a handful of whites in Tanna-not much more than a dozen all told. It is hard for the Tannamen to believe that these few white men and women have the power of a great Empire at their back, especially as no reason has been given them of late years to realise this fact. The late punitive expedition to Malekula created a smaller effect in Tanna than in any other part of the New Hebridean group, for Tanna lies far south, and its inhabitants are a different folk altogether to the Malekulans-braver, bigger, more warlike, and decidedly more intelligent. They will 
make a fine people when they are tamed. But at present, the taming seems rather the other way round.

Tanna's great volcano, famous as it is, has been very seldom visited. The Sydney boat touches at Sulphur Bay, or near it, twice every month, going and coming; but tourists are rare birds in the islands, and even when one or two do venture to brave the fevers and the cannibals (neither of which are nearly so black as painted), there is very seldom time for an ascent of the cone.

Besides, when there is time, the tourist is quite sure that he will be shot or eaten, or both, if he ventures into the interior. There is always an ugly report of murders (native) ready for every steamer, and the inhabitants of the island, coming down on the beach in warpaint, feathers, and full armament of rifle, cartridges, and bow and arrows, do not tend to allay any nervousness that the traveller may feel. So there are very few excursions up Tanna's fiery cone; except for those indulged in by the men-of-war officers, who usually "do" the volcano as a duty if their ship happens to cast anchor in the neighbourhood.

Things, however, are not exactly what they seem in Tanna. If they had been, one may be sure my kindly hosts of the mission would not have despatched me alone with a couple of pigeon-English-speaking native guides to ascend the mountain, and see what was to be seen. As to the cone of the volcano itself, one might safely assure the most nervous old lady who ever screamed at a mouse, that not a single heathen Tannaman would venture to set foot on the spot. The Tannese have a deadly horror of the place, and only a civilised mission native will venture to approach it. 
The climb is not a long one. I was not able to ascertain the exact height of the mountain, but it is generally supposed to be just under 2,000 feet, and this certainly seemed about correct. My "boys" and I started from the mission late in the afternoon, as I wanted to see the crater after dusk. I took things easily, and found that one could reach the mountain and get to the top in an hour and a half without much exertion.

We walked along the usual foot-wide bush track for a mile or two, passing through a couple of "mission" villages, where the people were clothed in bright pink and scarlet cottons, and had fairly decent houses; and meeting on the way an occasional wild "bushie," dressed in nothing at all, or in a sort of upholstery fringe of dried grass, according to sex. The women sometimes carried a pet pig, a tiny squeaker no larger than a cat, which they seemed extremely attached to, as a rule, and conveyed about under one arm, for all the world like a fashionable lady's lap-dog.

The boys, of course, kept up the maddening native pace that looks so slow and easy, and in reality is so hard to follow-a relentless, long, elastic, wolf-like stride, that never slacks or alters up hill or down, that comes of an ancestry unhampered by clothing, and a life spent afoot on rough, hilly tracks, and that is bound to wear out anyone but a very strong white man in excellent training, if one gives in to its apparent slowness and struggles to keep up. I did not, having long since learned that pride of this kind may be too dearly bought in a feverish, tropical climate. I simply screamed at them to go slow, and kept on screaming at appropriate intervals, until I reduced them to my moderate three miles an hour, and made them stay 
there. Other travellers may find the hint useful. The tangled bush-palm and pandanus matted together at the roots with purple-flowered shrubs and trailing pink convolvulus, and linked aloft by closely knitted lianas, thinned out by-and-by, and began to display a flooring of fine black sand. Then the trees ended abruptly, and we were out on a barren, desolate plain, painted crimson, buff, and yellow, curdled and coiled like the scum on boiling milk, and looking as hot and molten as though the wicked black cone in the centre had only this morning cast it forth. Yet these lava beds were old and time-worn, and where they did not clink like metal under foot, were half crumbled into rottenness. It is a long, long time-no one knows just when, since the volcano erupted seriously, though small outbursts are of constant occurrence. Still, it is by no means a force to be despised. The missionhouse, several miles away, is often shaken by small earthquakes that throw down the furniture and break the china; and even when the mountain is at its quietest, in periods of long drought (the connection is not understood, but drought generally means reduced activity), the throb and grumble of its crater can be felt over almost all the island.

After the lava beds are crossed, a plain of black sand, level as a lake, lies before us, and right in the centre, sinister and threatening, and grim, towers the 8oo-feet-high cone. A heavy cloud of smoke hides the apex; from rents and fissures in the steep, black sides rush jets of sulphurous steam. It is steep, but the climb seems short and easy, looking across the plain-one would imagine that ten minutes should place the climber on the invisible crest.

Alas! I have climbed volcanoes before, and I know 
those delusive cones. In ten minutes the men and myself are slipping, slithering, straining, and scrambling mid-leg deep in black ash, just on the beginning of the rise. Every step is half lost before it is well gained; we dig our fingers into the tepid ashes, and clutch at lumps of slag sticking out above our heads; find them give way, and narrowly escape rolling down into sulphurous, steaming cracks that will certainly show red-hot after dusk. In twenty minutes we are only about half-way up, but the worst is over, and our toes are no longer turned upward at an acute angle to our shins. We can see a valley on the other side of the cone now-a demoniac little place, full of sulphurous smoke-holes and ugly cracks; not the sort of spot in which to take a walk for pleasure. There will be a big outbreak there some of these days.

Up, still up! and now the sky-line in front of us is sharp and near, and darkly outlined against a livid cloud of smoke. We are almost there. One of the men has been here before; the other has not, but we are all equally eager, and we fairly run the last few steps of the rise, up to the very verge of the pit, where we stand flapping and shaking in a tearing wind, high above the blue sea and the circled green horizon, right on the volcano's fiery brink.

It is just a little disappointing at first. One had expected a sea of fire, a welter of flame-though warned beforehand that the mountain was sulking, and not at its best-and here, when the stifling sulphur-gusts roll far enough to leeward to show the interior: is but a great black pit, with a red crack across the middle, and a red fire-fountain jetting up drops of blood away in the bottom. And after all, is it so very large?

But suddenly, without any warning, as I stand on 


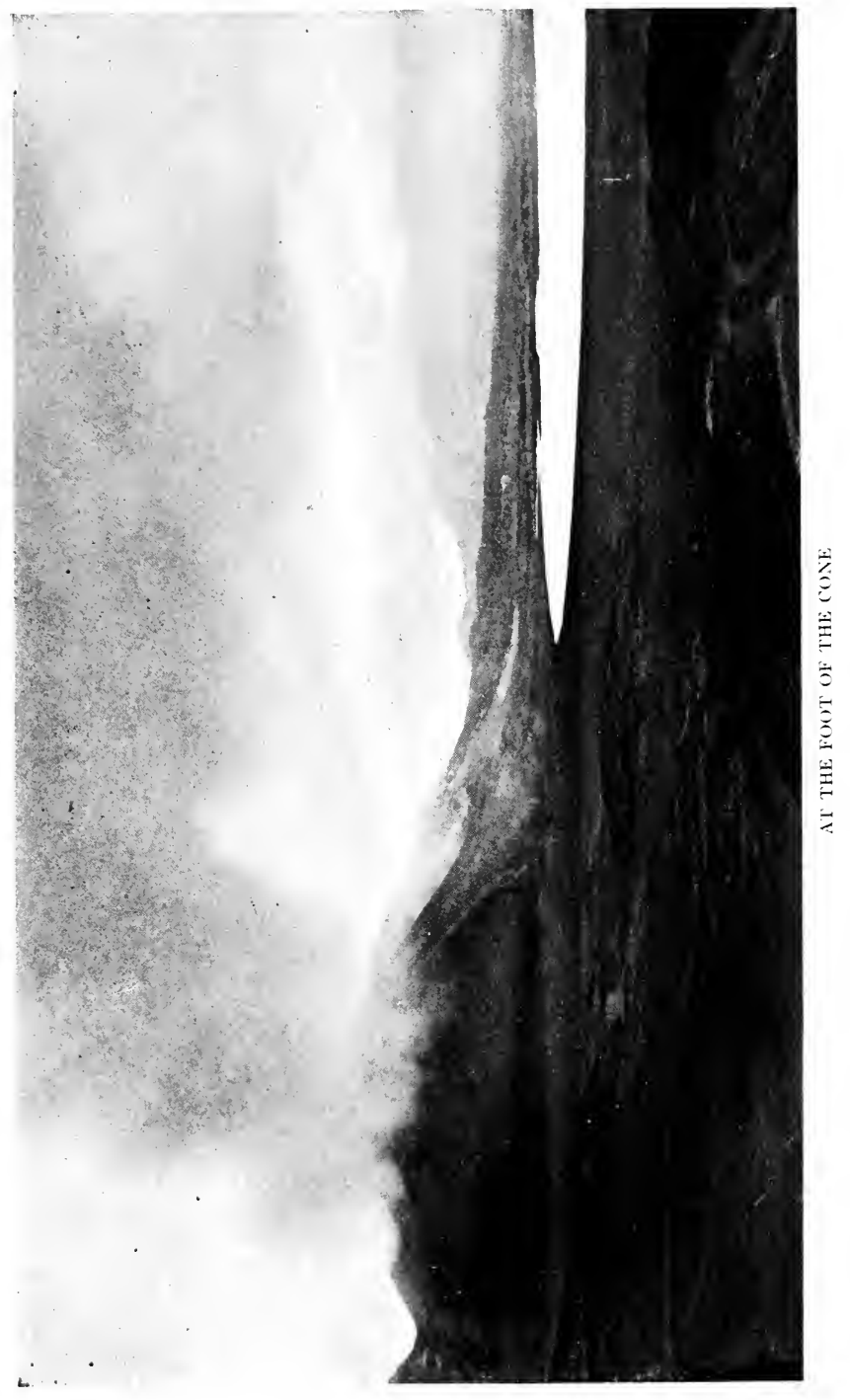




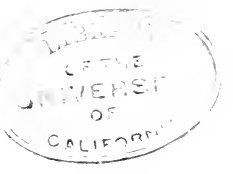


the edge looking over, and feeling rather giddy, without understanding why the scale of the place bursts upon me. I realise what I am looking at. The sky-line of the crater shuts out so much of the surrounding world that there is nothing to compare with-but somehow the "values" explain themselves all in a second, and the crater expands like a bursting red flower, while I, deprived of my lawful sixty-nine inches and comfortable self-complacency, stand like a wretched little insect, a speck that does not count, on the verge of utter immensity. . . . It was merely my eyes, accustomed to things of moderate size, that were in fault, not the crater. Eight hundred feet is the drop from where I am standing to the sulphurous gorges and canyons beneath; half a mile at the least is the distance from lip to lip of the great black cup. And as for the powers that sleep below. . . . I did not mean to do it. I thought I had developed some nerve during the course of some months' solitary wanderings about the wild New Hebrides. I thought I could face a noise without losing head and presence of mind. But the fire-fountain jumped a hundred feet higher into the air, and the crater, like a wild and wicked brute when you put your head into its den, suddenly bellowed right into my face with the voice of a dozen tropic thunderstorms and a thousand angry bulls; coupled to something that was entirely volcanic and indescribable-something that turned one's spine to an ill-set jelly, and made one mysteriously understand the motions of the star-fish that jerks off its arms and legs when suddenly terrified. I wanted to jerk off mine, but instead, I found myself running down the side of the cone hand-in-hand with twc extremely frightened niggers, without an idea as to how I got 
there, or where I was going. It was not courage, for I had none left, but pride of race, that stopped me half a dozen yards below the crater lip. White people must not be frightened before blacks. So I went back and sat on the edge again-because the rush of hot wind from below, and the extreme straightness of the 800feet-drop, inclined one to giddiness-and looked down again. By-and-by it bellowed a second time, and the very heavens shook, while the caky crumbled edge I sat on trembled heart-shakingly. But I wanted to see this time, so I looked down, still feeling very much like the star-fish, without its happy means of relief.

It was all over in a few seconds. The fire-fountain rose half-way up the crater sides, and tossed a few glowing lumps of lava into the air. They did not reach within a hundred feet of the rim, but it was rather anxious work, seeing how far they meant to go. The red crack glowed scarlet; and from the dark wolf-mouth away down at the bottom of all things, burst once and again that terrifying bellow. It was impossible not to feel that there was something alive-alive and powerful and infinitely wicked-about the place. It was impossible not to read anger and menace in the tones of that awful thunder-voice. It was the voice of Nature herselfbut

\section{"Nature red in tooth and claw With ravine."}

Nature, pitiless, avenging and cruel. The Nature of floods and earthquakes, hurricanes, simoons and fire. The Nature that sweeps man relentlessly from her path in her anger, and blots out a countryside of crawling human folk in a single hour. If any man says that he can look down the throat of such a devil's 
pit as this without emotion, and hear it speak without fear, I think that man must lie.

For more than an hour I stayed on the summit, watching the crater with a fascinated fear that seemed to expunge both time and fatigue. As the sun went down in the glassy blue sea, and the sky began to darken, the whole of the great pit was slowly lit up from below as by some infernal illumination. The gray plateaux of lava turned pink, and became spotted with holes of fire. The huge canyon darted flames invisible in the daylight; the fire-fountain glowed like molten brass. And every now and then, as if the current of the light were being turned on below by a giant hand, the whole crater slowly brightened and glowed, and the canopy of dull-red vapour hanging above it grew scarlet. At such times, from the other side (an untenable position, by reason of the choking sulphur smoke), there must have been a marvellous view of a fiery valley, of which I could only see the overhanging tableland. . . . I never longed for anything so much as I longed to see into that invisible and unattainable gorge of flame.

And over all, above the jettings of the fire-fountain and the booming of the crater-throat, rose, silent, still, and pure, the dark-blue heaven and the eternal stars. . . . If one could write the thoughts that come in such hours and places, one would "speak with the tongues of men and angels," and say that which cannot be said. But through the iron bars of human speech, the human soul can look forth but a very little way.

The wind on the summit was bitter cold, but the cinders of the cone on which we stood were so warm that the hand could not bear the heat five or six inches below the surface.

It would have been quite possible for me to find a 
spot in the lee of a hillock, scratch out a very warm nest among the ashes, and spend the night there, and see the sun rise, sending the men on to explain my absence. But . . . we had eaten all our food, and there was no water left. And one gets desperately thirsty watching a sulphurous crater in full blast. And the thought of the lemons and cool tank-water down at the mission proved too much, so I went down without spending the night, and regretted it long after.

The touch of comedy that always follows close on the heels of tragedy in "the islands" was not wanting here. When the two Tannese guides had finished running away (which they did at every explosion, until they were tired out), and, clinging close together, had ventured to look down into the crater, I listened with considerable interest to hear what form the untutored savages' expression would take at the sight of this most colossal of Nature's wonders.

One untutored savage looked down at the fiery valley below, and then drew back, remarking calmly "All same calico!" (It is necessary to explain that the Tannaman always buys red cotton.) The other rose more fully to the occasion. He looked over likewise, drew back, and remarked very gravely: "All same hell!"

A few nights afterward, lying off the island in the Malaita, I could see the crimson cloud hovering high above the black cone, blotting out half the crystal stars. Every now and then, as before, the crimson brightened into pure red gold, and then faded again. And from time to time, the cloud-cap trembled and the hollow arch of midnight sky resounded with the booming roar of the great volcano's voice. So Captain Cook found this southward sentinel of the New Hebrides, 


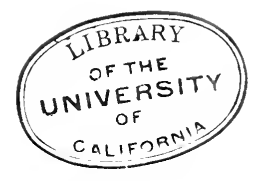




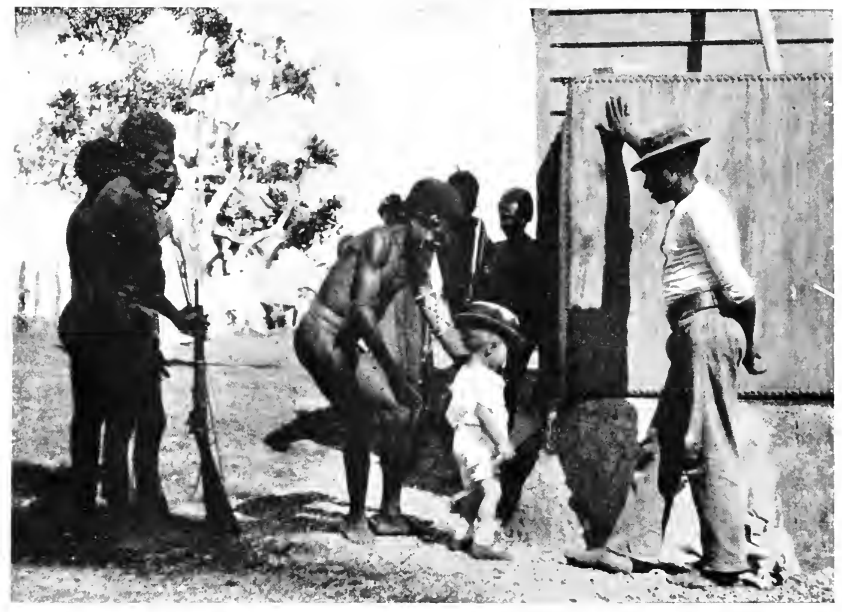

BUSHMEN COMING TO SEE A WHITE CHILD

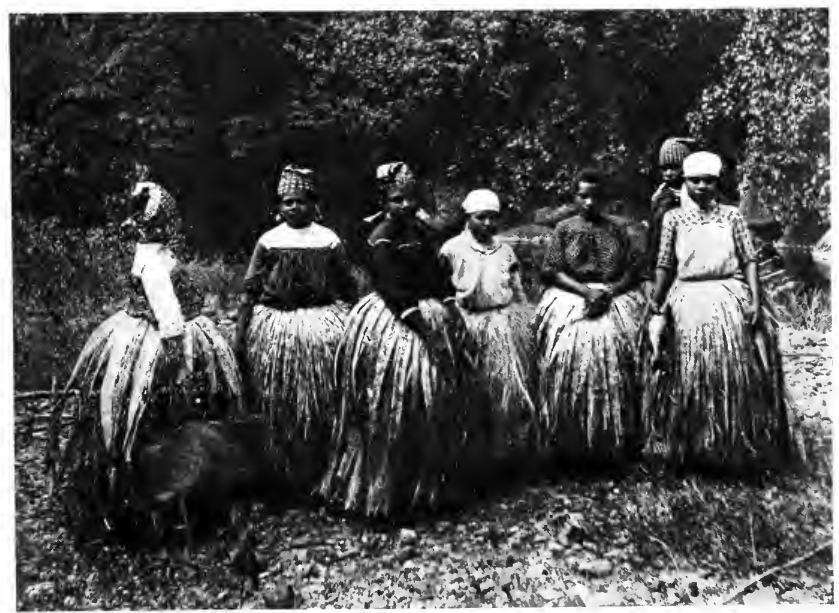

FASHIONS IN ERRUAIATA 
more than a hundred years ago. So we found it, and left it, eternal and unchanged, and sailed southward with the dawn, away from the islands.

About Erromanga, the "Martyr Isle," there are a good many misconceptions. The murders of five of the early missionaries on this island, including the celebrated John Williams, have fixed an idea in the public mind that Erromanga is the home of fierce savages, and almost uncivilised. On the contrary, it now shares with Aneityum the honour of being the most completely civilised and Christianised island in the group. The last murder took place thirty-four years ago; and the islanders are now as peaceable and amiable a set of people as can be found under the Southern Cross. Much of the island is given up to sheep-farming, the soil and grass being excellent. It was rather a disappointment that the steamer only paused at Erromanga to land a passenger, and did not wait at all, so that no visits could be made. But that is one of the difficulties of seeing the New Hebrides. Without a private yacht, at least six months would be needed to see all the important islands, unless one chose to be satisfied with a single morning or afternoon's survey of each.

The same difficulty tantalised one at pretty little Aneityum-a month, or nothing. But after all, the Aneityumese are civilised out of all interest.

It is very gratifying, from a moral point of view, to see the clean, tidy, school-attending, prosaically peaceful folk that have replaced the original savage; but to the traveller, original savages are a good deal more interesting.

Ambrym, with its great volcano-which takes several days to visit-and the number of heathens it still 
possesses, was much more tempting, especially when one heard that many strange native customs survive here, among them the law which compels a woman who meets a man to kneel down and crawl past him on all fours! The Ambrym mission hospital has had many cases of housemaid's knee to treat, owing to this peculiar form of showing respect to the "lords of creation." And as for Santo, with its savage people, its strange relics of sixteenth-century Spanish history, and its reported ruined city - relic of De Quiros and his "New Jerusalem" -one would make a trip to the islands for the sake of exploring it alone, if time allowed. But time, which in one sense does not exist in the New Hebrides, is, in another, the greatest barrier between the group and the outer world. To see all the islands, you must have time to spare, time to burn, time to throw away-an iron constitution, unlimited patience, and plenty of money as well; but above all things, time. And the few months that I was able to amass to spend on the New Hebrides were not by any means enough. So Santo and Ambrym went by the board; Erromanga was passed by, and Pentecost, Aoba, Maewo, and Aurora not even looked at. It was a pity-but I was not an exploring expedition, worse luck.

At present the islands are in a state of paralysis, so far as British enterprise is concerned, on account of the duties already discussed. Nothing can be hoped until these are removed. But if, or when, they are, there is certainly a field for enterprise in the New Hebrides. Almost any tropical product will grow, and grow well, and Erromanga has a future before it for sheep-farming on a moderate scale. Malekula is of little or no value to the settler, being almost all mountainous bush of the densest kind; but many of the smaller islands could be 
used profitably if there were only a market for their products.

Island fever is a matter of the greatest possible interest to all settlers and travellers. It may be said at once that the dangers of New Hebridean fever have been greatly exaggerated. Many people appear to suppose that the islands are ravaged by dread diseases resembling blackwater, yellow and typhus fevers, which lay hold of the newcomer without warning, and kill him off in a few days. This is, of course, absurd. Malaria there is in the New Hebrides; plenty of it, too, and almost everyone suffers from it more or less. But malaria only kills indirectly, by means of gradual weakening of the constitution; and if good food is eaten, and common precaution as to health observed, it may be, and often is, escaped. 


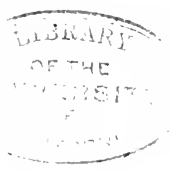

. 


\section{CHAPTER XVI}

\section{NORFOLK ISLAND-GOOD-BYE}

The Story of Norfolk Island-A Woman in the Case-The Fate of the Mutineers-In the New Home-A Valley of Peace-Good-bye

N THE way to the New Hebrides lies an island of which mention cannot be omitted, in describing this part of the Pacific. It is a British possession, six miles by three, lying a thousand miles northeast of Sydney; it has a population of about eight hundred half-castes, and a hundred whites; and it was for many years notorious to the civilised world as the worst plague-spot in the whole plague-smitten system of colonial transportation.

To-day, Norfolk Island is the most peaceful, sunny, and happy spot under the Southern Cross. Lovely almost beyond description it always was, but in the old, bad, convict days, its loveliness, if felt at all, was felt only as a mockery of the wretched imprisoned lives that dragged themselves slowly there to a miserable end, or-more fortunate, as they counted it-were swung quickly out of life some morning, on the arm of the never-sated gallows-tree-

Anywhere, anywhere, out of the world!

How the change came about, is a long story-so far forgotten by the world in general, that one may well risk telling it again. 
Ten years passed by. It was 1800 now. The homes still stood, the fertile ground bore richer harvests than ever, the little feet of the children were many about the green valleys of Pitcairn. But where were the parents - the sailor fathers, the soft-eyed brown Tahitian mothers -and where were the Tahitian men who had followed their strange white friends away into exile?

Dead, all but one miserable, horror-struck, repentant soul-the sailor Adams. He alone survived-he and the innocent children. The ten years that had passed had been ten years of drunkenness, debauchery, fighting and murder. First, the men had found out the way to make intoxicating spirits from the products of the island. Then, they had set a-quarrelling about each other's wives. Then murder had been done, and done again, and some had died mad with drink, and others had sunk from disease. And the end of it all wasAdams left on the island, the guardian of the childrenalone.

The man had been piously brought up in his youth, and old teachings returned to him now. He vowed to make his life an expiation henceforth, and to bring up the dead men's children honestly and well. The vow was nobly fulfilled. When Adams died, some twenty years later, he left the island a model of every Christian virtue, inhabited by a people of remarkable innocence and goodness, who knew nothing of the outside world, but supported themselves entirely on the produce of their island home, and reverenced their aged guide as the best and wisest of men.

Adams was succeeded in his governorship by a stranger, one Nobbs, who drifted up to the island in I828, and being a worthy character, was not long in gaining the confidence and affection of the people. The 

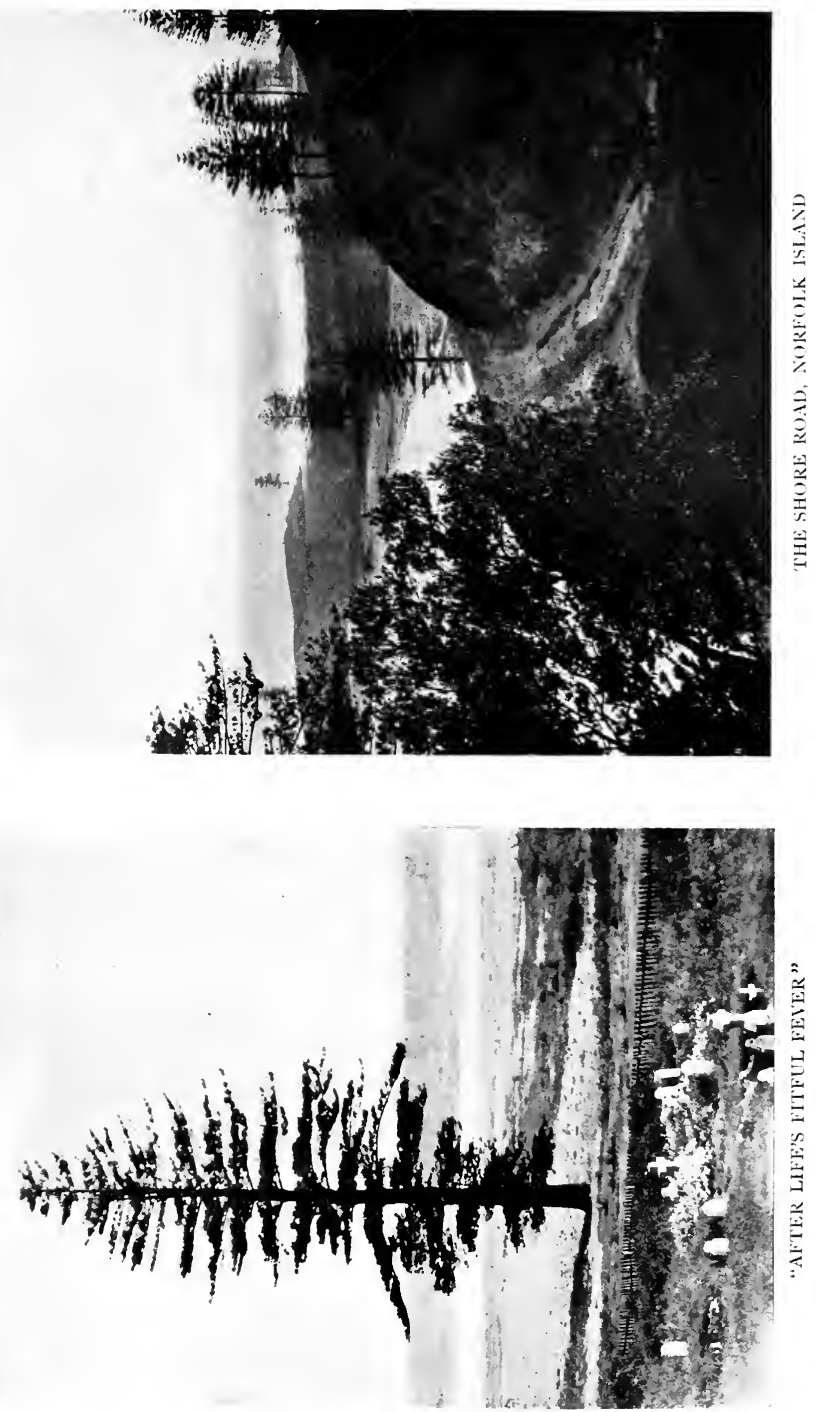
0 
inhabitants of Pitcairn now increased rapidly; ships called more frequently, and the world began to hear about this strange little colony, and to take a romantic interest in it. Then began a system of "lionising" the descendants of the Bounty mutineers, that has continued, in one way and another, ever since, and that has certainly not been for the good of the people. With publicity came visits, gifts, patronage of various kinds, and at last, in $185^{6}$, when the population, now near two hundred, had almost outgrown the limits of the island, came the handsomest present of all-beautiful, fertile Norfolk Island, which the British Government offered to the people of Pitcairn for their home.

The gift was gratefully accepted, and the Pitcairn Islanders moved across the Pacific, in a ship specially placed at their disposal, to their new possession. A few returned shortly after, but the great majority stayed.

Norfolk Island, at that time, had been lying vacant for some years. Discovered by Cook in 1774, it was in 1826 taken into use as a prison of special severity for the worst characters among the criminals transported to Tasmania ("Van Dieman's Land").

The atrocities of the Norfolk Island convict system have been made familiar to the world in Marcus Clarke's terrible book, "For the Term of His Natural Life." The judgment of history acquits that merciless indictment of all exaggeration. Whatever the crimes of the prisoners may have been-and in many cases they were great, though in many again they were the most venial of offences-the punishment which all alike endured, in the hell of Norfolk Island, was savagely disproportioned to the ill-doing that brought it about. The discipline was so severe, and the labour so hard, that suicide was actually epidemic at times. Convicts used to draw lots 
for who should kill the other, thus releasing two miserable prisoners-one by murder, and one by execution. On the gallows that stood always ready before the prison gates, men used to be led out by dozens at a time for slaughter. The lash was busy at the triangles half the day. Men were worked on the roads, and at clearing labour, until their worn-out bodies gave way, and then tortured almost to death, or quite, for breaking down. Iron rings in the walls, to which the prisoners were chained like beasts, are yet to be seen in the crumbling ruins of the prison buildings. In the little, still, sunny graveyard that lies far beyond the town, on the edge of the lonely sea, there are many nameless convict graves among the white stones that mark the tombs of those who came after. . . Honoured names at home, it may be, some of them, long and long ago-before the fatal cheque was signed, or the blow struck in anger. . . . Outcast for ever after, forgotten of man, and almost, it seemed, of God, driven to death, and cast into an unnamed grave-here, "after life's fitful fever, they sleep well"-under the shadow of the singing Norfolk pines, while Nature, kindlier than man, covers honoured and dishonoured graves alike with tender leaf and flower.

The shadow of misery and crime has long since passed away from the beautiful home of the Pitcairn people. The convict station had been permanently removed some years before their arrival, and the unoccupied buildings-soldiers' barracks, storehouses, prison-were converted by the new owners into churches, courthouse, and schools. They found the island in such order as never another island in the Pacific could show-the whole surface of six miles by three as well cleared and laid out as a gentleman's park in England; splendid 
roads and substantial bridges constructed, weeds and poisonous plants cleared away, and only so much bush left in out-of-the-way places as might serve to protect the game. Free men, working as ordinary settlers work, would not have done as much in a century as had been done by the convicts in less than one generation. It was slave labour, and it performed colossal results, as slave labour has done since the days of the Pyramids onwardnot often, though, on British-owned soil, and in the Victorian age of England.

The Bounty people, numbering I94, settled down contentedly in their new home, and increased rapidly. During the half-century that followed their occupation of the island, the world heard a good deal about them from time to time, in spite of the fact that the place was visited only by stray whaling ships. Queen Victoria was much interested in the people, and sent them gifts of goods and clothing more than once. The sentimental world of the sixties shed the tear of sensibility over their innocence and virtue. They formed the text of many a magazine sermon on the uselessness of riches, such as was popular, and profitable, in the seventies and eighties. Later on, whispers began to circulate in the colonial press, suggesting that the innocence of Norfolk Island was growing a little out at elbows; but the public fancy would not be deprived of its toy so easily, and it was not till a Commission appointed by the Government of New South Wales reported unfavourably on the general condition of affairs in the island, that people began to realise the Norfolkers were only human. Quarrelling and malicious outrages, it seemed, had become frequent, the island council, which had always administered justice, was ceasing to give satisfaction, and the morality of the place left much to be desired. Under these circumstances 
it was thought best to annex the place to the Government of New South Wales, and this was accordingly done in 1902, with the consent of the people. Since then, a resident magistrate from Australia has governed the island, and law and order are firmly reëstablished. Captain Drake, R. N., and Mrs. Drake, are greatly loved by the kindly islanders, and their occupation of Government House has been in every way for the good of the people.

The Norfolk Islanders now number over eight hundred, and there are about a hundred white immigrants of various kinds, most of whom belong to the newly established cable station. The islanders themselves have intermarried with whites so little as not to count, and are, therefore, still half-caste. The natural tendency is to suppose that "they must be nearly white by this time." Of course, this is not the case, as the half-caste children of the Bounty sailors and the Tahitian women have been intermarrying ever since, and the dark blood is still there. There are only eight surnames among the eight hundred people-they are all Adams, Nobbs, Fletchers, Quintals, Buffets, M'Coys, Christians, and Youngs, all related and re-related and intermarried in a manner that no outsider could possibly disentangle. Everyone is everyone else's cousin many times over, everybody resembles everybody else to such an extent that the newcomer never knows who his acquaintances are; most people on the island live alike, think alike, talk alike. There are some variations, however, mostly in the degree of colour. Many of the islanders are as white, save for exposure to the weather, as most English, and others are no darker than Italians. Some, again, are as coffee-brown as a full-blooded Tahitian. There are different types of feature among them. I have seen a 


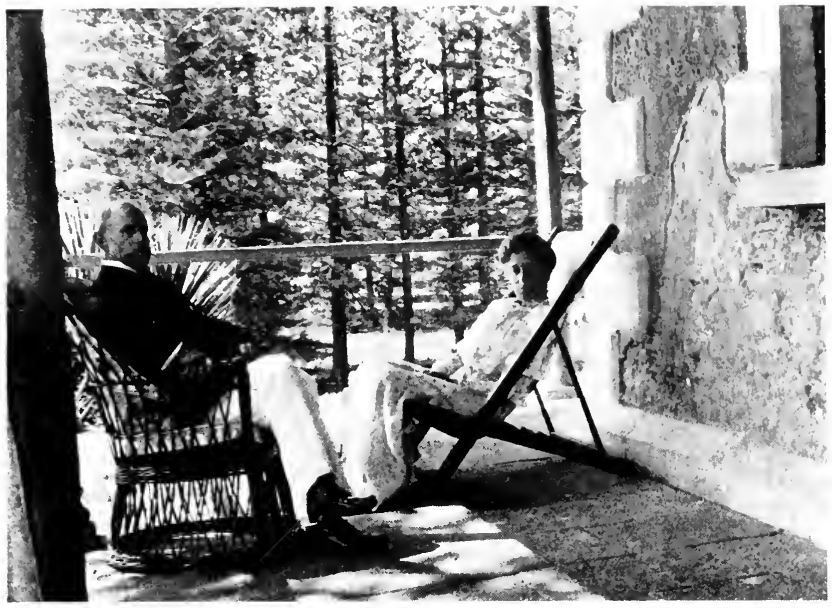

CAPTAIN DRAKE, R. N., AND MRS, DRAKE

GOVERNMENT HOUSE

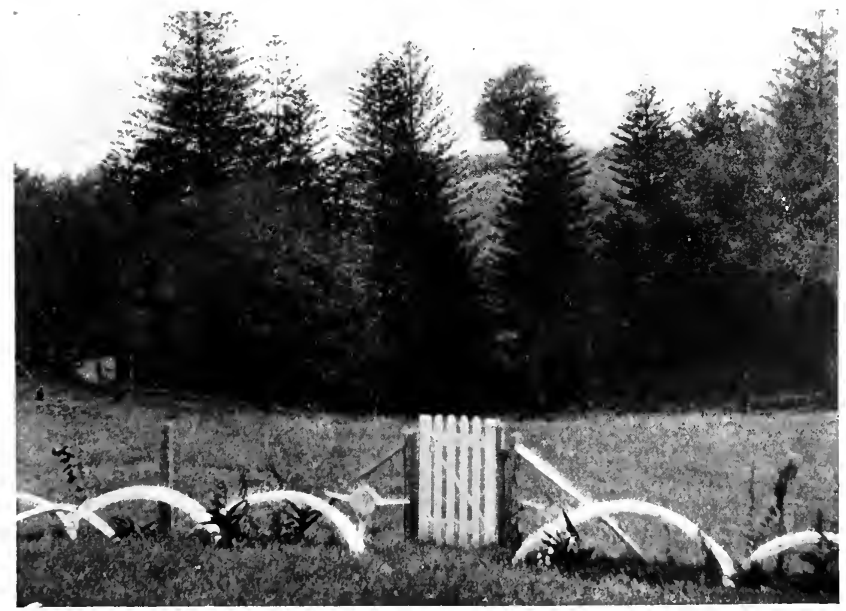

GARDEN FENCE OF WHALES' RIBS ANI VERTEBR.E 


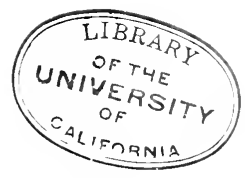


Christian (descendant of the Bounty officer of that name), who had the typical face of the well-born naval man, to a line. He was barefoot, and wore rough dungarees, could read and write, but nothing more, and was glad of any small labouring job that put a penny in his pocket for tobacco. . . . Christian, the lieutenant, involved in the mutiny against his will, driven to brutality and crime by despair, and scorched throughout his brief life on Pitcairn by such a sense of burning degradation as only a broken King's officer in like case could know, begged at the last to have his grave concealed, and his name forgotten. The world would find the refugees some day, he knew, and he could not bear the thought of his name, once honoured, going down to all the ages as that of a traitor to his King. . . . It was a wish impossible to fulfil. The Eighteenth-Century officer might turn in his grave to-day, if he could hear how often the tale of the mutiny is told, and how proudly his half-black descendants cling to every fragment of property, each garbled tradition, left behind of the life that he only wished to be forgotten in its unknown grave for ever.

Among the women, many show traces of the beauty that was the undoing of the Bounty men, long ago. Large dark, shining eyes are common, with long soft hair, pleasant features, and a singularly sweet smile. The voices of all the islanders are remarkably low and musical. They are the voices of those whose ancestors for many generations have never known hurry or anxiety, of people dwelling in "a land where it is always afternoon"-of a gentle dreamy folk, living slow sweet lives as changeless as the empty sea that rings round their island home. Music is a passion with almost every islander, and the tendency shows in their curious half-singing speech. 
They are a dreamy folk, too, and will lie motionless for hours under the murmuring pines, looking at the seajust as the indolent amiable Tahitian lies to-day, on the grassy shores of the road leading out from Papeëte. But the sailor blood shows too, and strongly. There are no finer boatmen, no more daring whalers, in all the Pacific, than these indolent dreamers, when the mood for action is on them. Most of the small stock of solid cash which they need for clothing, groceries and other luxuries of civilisation, is obtained by the sale of whale-oil. This is a smaller source of income than in former times, since the price of whale-oil has gone down considerably, but a good deal is still made in this way during the season, which lasts from about May to October.

I was not fortunate enough to visit Norfolk Island at that time, and so missed the exciting spectacle, which is occasionally to be enjoyed, of huge whaleboats tearing through the sea at the speed of an Atlantic liner, fast to a furious whale. The chase is a dangerous one, but those who have had an opportunity of joining in it say that there is nothing else in the world of sport to compare with it. And indeed, one can well imagine that the biggest of big game shooting might seem tame beside it.

It is a fortunate thing, for the traveller who loves quaint and unspoiled places, that the five days' passage from Sydney (usually stormy), in a small steamer, keeps the tourist world away from Norfolk Island. Only a stray wanderer drifts up now and then, to seek for health, perhaps, in the quiet island valleys, or to spend a holiday away from the cruel heat of Australia. The people are glad to take in a boarder, and to make a little money for dress goods, sugar and tea, and they are (like all Pnlynesian or semi-Polynesian races) the soul of hospitality. If the absence of contact with the 
outer world has made them simple and somewhat narrow, it has also preserved them entirely from things that are worse than a limited outlook. Every Norfolker, barefoot, uneducated, and unversed in the ways of the world of society though he may be, is nevertheless a gentleman in all essentials. The quiet self-possession, the low pleasant voice, the easy courtesy of the Norfolker to any stranger, whether a globe-trotting peer, or a brokendown sailor run away from his ship, can only be matched elsewhere in what is known as "the very best" society. There is not the first trace of a snob about him, and the gnawing worm of social ambition never eats at the heart of his sun-warmed apple of life. Norfolk Island has a bishop, a number of clergy, a carefully graded set of cable company officials, one or two unoccupied land-holders, and, various store-keepers, large and small, so that all the materials for cliqueism in its worst form are there"instead of which" everyone in the island knows everyone else on terms of complete equality, the shoeless fisher-lad beats the bishop at tennis, and goes to tea with him afterward, the pretty island girl who is parlour-maid at Government House chats to the visitors as she waits at lunch, and the distinguished stranger arriving at the island will probably be asked to join the butcher's or the carpenter's family in a picnic up Mount Pitt-and will certainly enjoy it if he goes. Yes, the flavour of story-book Arcadia has not deserted Norfolk yet, in spite of governors and cable stations.

Every family has its own share of the land, and raises its own crops of potatoes, kumara (sweet potato), Indian corn, and fruit. There is plenty of land for all, and some over. The whaling industry is carried out by the men who are in the prime of life, and the proceeds divided among the different families by a system of "companies." 
So many families belong to A company, so many to B company, and so on. The entire proceeds of the season's whaling for each company are divided among all the families supplying active members to the company. If a woman's husband dies, she still continues to draw her share from the company to which he belonged, for Norfolk Island is kind to widows. Every family has its own cattle and horses, both of a good kind as a rule, and fowls are very commonly kept. Fish abound round the coasts, and fruit runs wild everywhere, and there are fine pheasants in the bush, and a perfect plague of fat quails. Thus, the island itself provides all that is necessary to life, and the proceeds of the whaling, or of fruit and onion farming, go to furnish the small superfluities that even a Norfolk Islander likes to have.

They are a handy folk, and can turn their abilities to any useful art. All the people build their own houses, and there is not a house in the island (save one or two stores), that does not show the best of natural taste. The model is usually the same-a long, low, one-storeyed building, constructed of pine boards "weathered" to a delightful brownish gray; pine shingle roof, high and pointed, and topped with a gay red ridge-pole; deep veranda running all round the house, and a tangle of vivid flowering creepers overrunning the whole building. Round about it the stately Norfolk pines rear their splendid heads a hundred feet into the blue, and you shall see, almost to a certainty, a slip of level turquoise sea, set gem-like somewhere among the velvet folds of the green encompassing hills.

The most elaborate, and by many the most admired buildings on the island, are those of the Church of England Melanesian Mission. Norfolk Island has for many years been the headquarters of this mission, which has to 
do with the Solomons, and, in a lesser degree, with the New Hebrides. It owns a very handsome church, which, possesses, among other beauties, stained-glass windows by Burne-Jones, and some very elaborate pearl-shell inlay work done by Solomon Island converts. There are usually several hundred Solomon Island natives in the Church schools, being trained by a staff of missionary workers for teaching in their own islands. The English missionaries stationed in the Solomons come down here from time to time to change and recruit. The Norfolk Islanders themselves are partly Church of England, and partly Methodist.

Other objects of public interest in the island there are none, save the crumbling ruins of some of the old prisons, and a broken-down arch on one of the roads, known as the "Bloody Bridge," from a desperate fight that once took place there between the convicts and their guards. Philip Island and Nepean Island, lying close to the shore, are only interesting from a far-off scenic point of view, and there is not a single show waterfall or a rock with a fantastic name, or any place called anybody's "Leap," in the whole island. For this relief, the toomuch-experienced traveller will offer ready thanks.

Yet there is much to see there, and plenty to do, after the fashion of Norfolk Island, which is like no other fashion in the world. . . . Shall I tell it all, and let the world in general into the secrets of the prettiest and quaintest little place on the globe? Shall I let them know about the rich warm valleys where grapes run wild in the trees, and the purple globes of the passionfruit are strung as close on their long green tendrils as gems on a necklace, and gold guavas lie tumbled in the grass like the eggs of some magic bird, and peaches, that would bring a shilling each in Covent Garden, 
are left to rot on the ground, because there are so many thousands that not even the pigs can finish them, and oranges and lemons hang like lamps in the dark green boughs, and bananas droop under hundred-weights of yellow fruit, and red coffee-berries glisten in the low bushes, and melons and strawberries run riot in the garden land above? Shall I send the invalid of the cold northern countries, and the burning southern continents, looking after a climate that is one long sweet spring from year to year, without great heat, without chill or frost or hurricane or drought? Shall I tell of the exquisite beauty of an island that is all one flawless gem from shore to shore-that mimics delicately the best of summer English landscapes, and sets them in a frame of tropic sea, and hangs them about with beautiful alien fruits and flowers, as with a garland? Shall I tell of the kindly simple people, and the endless afternoons in some pineshaded house above the sounding sea, where a girl, with eyes of the burning South set in a face of pale old ivory, sits dreaming over a worn piano, and plays her dreams as they arise, and the father of the house, sea-bronzed and strong, tells wild unbelievable stories to the stranger of perilous adventures on the whaling-grounds? Nights when half the island is out a-dancing in each other's houses-days and weeks when lawn tennis is the only thought from dawn to dusk, and no one troubles about the crops, or the current European war, or the rise and fall of far-away kings, because there is matter more important afoot, in the fate of the Island Cup-half-days, and hours, and nights, taken up in an ecstasy of violin or harmonium or flute playing, with all the neighbours in hearing distance leaving their work and coming in to join-celebration days, when all the Bounty families dress in man-of-war costume, men in full suits, girls in 


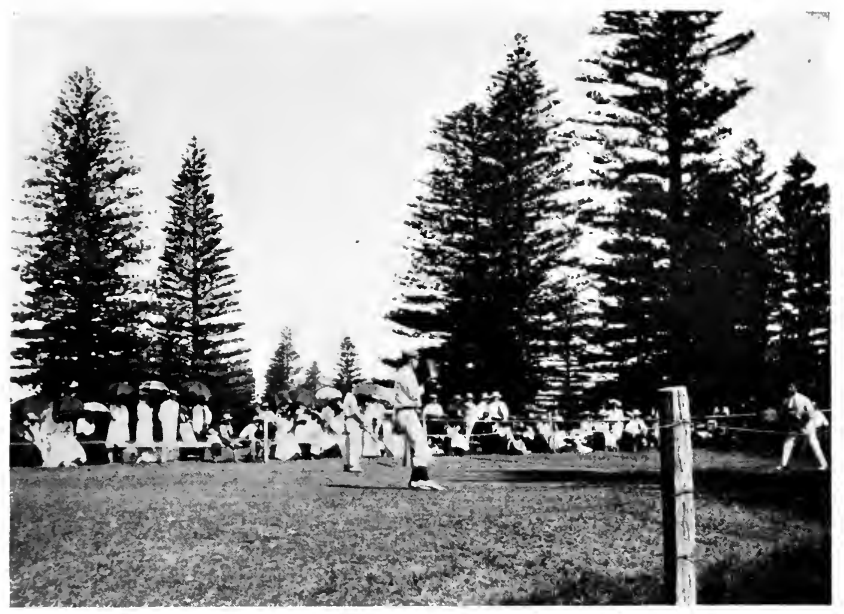

TENNIS, NORFOLK ISLAND

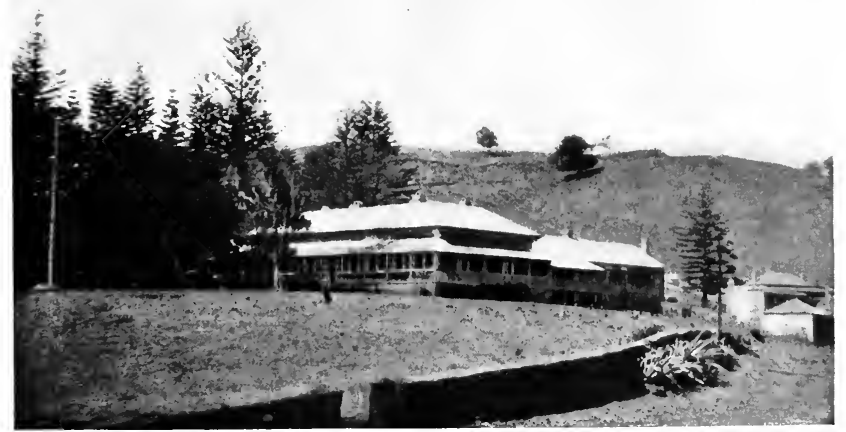

GOVERNIIENT HOUSE, NORFOLK ISLAND 


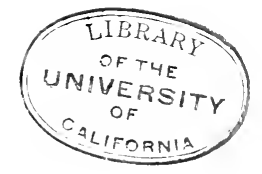


jumpers and white skirts, and commemorate the day when their forefathers landed on Pitcairn-mornings of wild riding on sturdy island horses among the beautiful hills, with companions, men and women, who sit saddleless, yet steady as centaurs, and race the wellequipped visitor madly up and down hill. . . Yes, one may safely tell it all, for most of what one says will not be believed-are not travellers proverbial fictionmongers?-and Norfolk Island is so very far away, that of those who do believe, and would willingly go and find this wonderful Vale of Arcady, scarce one will be able to find an opportunity. So the bloom may remain on the fruit for just a little longer.

The islanders have their faults. They have been lionised and petted by a far-away public, too much and too long. They are a little vain, in consequence, and somewhat inclined to over-estimate their own importance on the mighty map of the world. And-as one might well expect-these children of lawless mutineers and sensuous Tahitians are sensuous themselves. Yet, after all, none of their faults equal, or even approach, the corresponding vices of more sophisticated nations. And they are very lovable, very generous, very kind, one may well leave criticism at that.

Intermarriage is becoming a serious question. The islanders passionately admire one another, and are clannish in the highest degree. They marry almost altogether among themselves, and the results that might be expected are beginning to show. The type of physique is distinctly on the down grade. Consumption is becoming rather common; cancer is seen now and then; rickets is not unknown, and there is rather too large a proportion of weak intellect. Efforts are being made by the resident magistrate and the Government doctor to 


\section{FIJI AND ITS POSSIBILITIES}

induce the islanders to marry into other families, but so far without much result.

No one who ever stayed in Norfolk Island left it without regret. No one ever left it, but would dearly love to visit it again. It is one of the few spots on earth's surface that takes close and lasting hold upon the hearts of all who know it.

So-not because they were ended, but because a book must end-the tale of my wanderings closes. If there is a moral, or a meaning, the reader must find it. 
INDEX 



\section{INDEX}

\section{The Jiji Jolandg}

Roure: London, down the coasts of France and Spain, up the Mediterranean, by Scylla and Charybdis, Port Said, through the Gateways of the East; Red Sea, Aden, Indian Ocean, Ceylon, 3. West Australia, Melbourne, Tasmania, Sydney, 4. Fiji, Suva, 5-3o. Viti Levu, 5-8I. Ba, over the hills and far away, 30-33. Pandanus Prairies, 33-37. The Naloto Range, 37. A Tropical Forest, 37-39. Nandrunga, 40-47. Tambale, 47. Nambukuya, the city of a dream, 47-54. Natuatuathoko, 60-65. Singatoka River, 60, 63, 67, 68. Lemba-Lemba, an important town, 70 . Koronisingana, 73-75. Mavua, the biggest town on the Singatoka River, 76-8r. Vanua Levu, $83^{-1} 3^{8}$. Lambasa, principal Port of Vanua Levu, 83. Vuo, 87. Wainikoro River, 9I-96. Wainikoro, 96. Wainikoro River, 97-98. Ndreketi River, IoI-II9. Tambia, a place to let alone, IoI-103. Nanduri, a high-class town, 103-107. Tumba, a town on the Ndreketi River, I07, III-II9. The Ndreketi or Senganga district, the "back of beyond," I 2 I-1 38 . Nanduri, I 28, I 29. Lambasa, I 29-I32. Taviuni, one of the larger islands, I $32-137$.

Agriculture, see also Industries, and Products

Australian emigrants, 12 cattle, $38,57,62,67$, II 7 I $32-137$

fowl, $51,55,71,74,76,79$, $94,95,104$, I I 4 , I I 7

horses, 57

pigs, $53,57,65,71,74,78$, $79,95,104, I_{4}$

sheep, 57

vanilla plantation, 23-25, I $30-132$

Allamanda, I 23

Allspice, 28
American Civil War proved the importance of Fiji's cotton industry, I 2

Andi Keva, a coasting steamer, 77

Anglo-French Convention, I39 Animal life

birds

fowl, $5 \mathrm{I}, 55,7 \mathrm{I}, 74,76$, $79,94,95,104, I_{4}$, I 7

honey-birds, II 6 , I I 7

fish parrots, II 6 ,

river-clams, 79 
Animal Life

fish

crayfish, 65, 7I, 79 I04, I I 4

prawn, 55

insects

shark, 69, 98-99

beetles, I 23

centipedes, I I 6-I I 7, I 23

fleas, I $23-125$

flies, IOI

leaf-insects, I I 7

mosquitoes, 7

scorpions, II 7

stick-insects, I I 7

mammals

ticks, I 6 , II 7

cattle, $57,62,67,80$,

II 7, I 32-I 37

goats, I I 7

horses, 57

pigs, $53,57,65,71,74$,

$78,79,95,104, \mathrm{II} 4$

sheep, 57

wild boars, II 6 , II 7

reptiles

wild cats, I 6 , II 7

chameleons, Ir 6

serpents, I 6

snakes, I 6

Annatto, 28

Areca-nut palms, 28

Armed native constabulary, 9, 2 I, 86

Arrowroot, 28, 105

Astrolabe, D'Urville's ship, Io

Australian emigrants, x 2

Azalea, 39

$\mathrm{Ba}, \mathrm{1} 7,30,3 \mathrm{I}, 3^{8}, 5^{8}$

Bad Lot, (Tha Levu), a hereditary devil-priest, I 22

Baker, Sir Samuel, 98

Bamboo, 36, 4I, 42, 44, 45, 48, $60,61,63,74,76,97,124$

Bananas, $17,28,35,42,47,48$, $53,54,67,80,105$, I I

Banks, cannibal group, 9
Bar at the mouth of the Singatoka River, 67-68

Ba River, 58, 80

Bau ndina, a rose-red wood, I 3

Bau, Thakombau's birthplace, 62

Bau vundi, a kind of cedar, II 3

Beardsley, Aubrey, 34

Beauty in Fiji, 9

Bed, a colossal, 43-44

Beetles, I 23

Bethune, Capt., explorer, Io

Biology, see Animal Life

Bligh, explorer, ro

Bog, a treacherous, I08-I Io

Bosi, or Council of Chiefs, 73

Botanic Gardens, Suva, 27

Botany, see Plant Life

Bounty, mutiny of the, ro

Bread-fruit tree, 42

British Colonies

coloured citizens, I 8

Constitution, I 8

Government, 9, $\mathrm{x}_{3}, \mathrm{I}_{4}, 5^{2}$ 57

improvements, I3-I 4 , I8

Bua-bua, the box-wood of the Pacific, II 2

Building, 2I

Buildings

church, 53

Government House, 6, 22

house of a mission-teacher, 49-50

house of the Buli of Mavua, one of the finest in Fiji, 77

house of the good Buli of Lemba-Lemba, 70-73

house of Turanga Liléwa ,46 jail at Suva, I9-20 mountain house, $4 \mathrm{I}-44,45$

Buli, term for a high chief, I 8,70

Burton, explorer, 30,56 , I 6

Cannibal Islands, I I

Cannibalism, see Murders

Card-playing in Nanduri, 105, 106

Cassia, 28 
Castor oil, 28, I 3 I

Cattle, $38,57,62,67$, I I 7

Cattle-ranching, $132-137$

Cells in Suva jail, I9

Census, 15

Centipedes, I I 6-I I 7, I 23

Cevua, or bastard sandalwood, I 12

Chameleons, I 6

Chestnuts, I 4 , I I 8

Chillies, 28

Chinese, 8, 86

Church, 53, I 2 I

Cigarettes, 53, ro9

Cities, see Geography

Citrons, 36, 38, 59

City, a dream, 47-54

Civilisation only varnish deep, 37

Civilised natives become excellent soldiers, 9

Clams, river, 79

Climate, 7, 32, 33, 57, 59, 68

Cloves, 28

Cocoa, 28, 79, I 18 , I I 9

Cocoanut, $42,55,67,71,73,75$, $78,87,93$, I05, 108, I 10, I 17, I 26

fibre (sinnet), 42, 50

Cocoa-palm, 79, I 8 -planting, I 19

Coffee, I 7, 58, 8o

Colonial Sugar Refining Company, I 7, 3I, 86

Commerce, see Industries

Constabulary, 9, 21, 86

Contents, vii

Convicts, 1 7-25

Cook, explorer, ı०, 98

Cook-houses in Suva jail, I 9

Cook Islands, I 5

Copra (the dried meat of the

Cotton, I 2, 3 I cocoanut), I 2, I 7, I 33, I 34

Crayfish, river-, 65, 71, 79, 104, I 14

Cricket-playing law, ro6

Crimes, I7, 18-25

Croton oil, 28
Crotons, 47, 6o

Curio shops, Suva, 27

Curry, 28, I 26

Curse of the spotted bun, 36

Customs

eating, 7 I

entering houses, rule for, 42,102

Dakua, wood resembling the New Zealand kauri pine, I I 2, I I 9

Dancing, 9

at funeral of great chief, 9

at wedding of great chief, 9

Mavuan sunset, 76

Meké-meké, a sing-song dance, 77-79, 105, 106ro7

solo, 9

tribe, 9

Waves of the Sea, one of the most celebrated dances, 9-ro

Decline of population, $x_{5},{ }^{6} 6$

Devil worship, I 22-I 25

Diseases, see Sickness

Dormitories in Suva jail, I 9

Dracænas, 47,60

Dress, 34, 35, 45, 53

Drugs, I 7

D'Urville, explorer, Io

Eastern Islands, 9

Eating and talking, two great ends of a Fijian's existence, 50-5I, 56-57, 65, 7 I, 75, $76,79,80$

Economic conditions, I 7

Education

early missionaries, Io, I I, I 3

Sunday church, I 2 I

Emigrants, Australian, I 2

Entering houses, rule for, 42, I02

Erythroxylon coca (from which cocaine is extracted), 28

Euchre in Nanduri, I05

Europeans in Fiji, census of, I 5 
Executive council of five for Geography

British Governor in Fiji, Lambasa, principal port I 4

Explorers

Baker, Sir Samuel, 98

Bethune, Captain, ro

Bligh, ro

Burton, 30, 56, iा 6

Cook, 10, 98

D'Urville, 10

La Pérouse, 98

Livingstone, 92, II 6

Speke, 30, 56, 92

Stanley, $30,36,56,83,116$, 128

Tasman, I0

U.S. Exploring Expedition, IO

Exports, $17,5^{8}$

Feasting, 9

Fever, $7,68,84$

Flag-staff Hill, Suva, 27

Fleas, $123-125$

Flies, 10I

Flowers, see Plant life

Food Products, see Products

Forest, a tropical, 37-39

Fowl, 51, 55, 71, 74, 76, 79, 94, 95, I04, I I 4, II 7 as served in Fiji, $5 \mathrm{I}$

Friendliness, 9

Funeral dance, 9

\section{Gardening, 9}

Garden of the Swiss Family Robinson, 27-28

Geography

$\mathrm{Ba}, \mathrm{I} 7,30,31,38,5^{8}$

Ba River, 58, 80

Banks, cannibal group, 9

Bau, Thakombau's birthplace, 62

Eastern Islands, 9

Kandavu, a province, $\mathrm{I} 4$

Koronisingana, 73, 74 of Vanua Levu, 83, 86, II 7, I 29

Lemba - Lemba, an important town, 70

Levuka, former capital of Fiji, 7, I 3, I I I

Mangaia, Island of, 16

Mavua, the biggest town on the Singatoka River, 76, $8 \mathrm{I}$

Moala, Island of, ro

Nambukuya, the city of a dream, 40, 47-54, 55, 58

Nandrunga, a small village, 40,58

Nanduri, a handsome town, 103-107, I 28, I 29

Natuatuathoko, a mountain fortress town, $57,58,60$, 6r

Ndreketi River, I0I-II9, I 2 I, I 22,128

New Caledonia, 38

New Hebrides, cannibal group, 9

Ngeo, Island of, $\mathrm{II}_{3}$

Niué, Island of, 16

Ovalau, Island of, 7

Prince William Islands, Io

Réwa River, 69

Rotumah, Island of, I 5

Senganga, the "back of beyond," $121-138$

Singatoka River, 60, 63, 67, $68,80,8$ r, 88

Singatoka Valley, 56, 75

Solomons, cannibal group, 9

South Seas, II, I5, 27

Suva, present capital of Fiji, 5, 6, 7, 13, I 7-25, 27, $28,29,3 \mathrm{I}, 67,80,8 \mathrm{I}, 85$, $88,103,117,119,122,128$, I 30, I 33, I 34

Suva Harbour, 27

Tamavua River, 27 
Geography

Tambalé, a tiny village, 47

Tambia, a place to let alone, IOI-IO3, I04, Ir 4

Taviuni, one of the larger islands, I 7, I I 5, I 32-1 37

Tavua River, 58

Tholo West Country (Singatoka and highlands), 132

Timor, 10

Tonga, group of islands, 12 , I 3,16

Tumba, a town on the Ndreketi River, 107, I I II I 9, I 22, I 28

Vanua Levu (Great Land), $6,23,83-99$, I I $3, I_{14}, I_{27}$, I 29, I30

Vatoa, Island of, ro

Viti Levu (Great Fiji), 6, 7, $39,83,86,87,88$, I I I , I I 4

Vuo, 98

Wainikoro, 87, 88, 9r, 96

Wainikoro River, $9 \mathrm{I}$

Gideon's transformation, I $25^{-1} 28$

wonder tales, 88-89, II 3I 4

Ginger, 28

Goats, II 7

Government

British, 9, 13, 14, 52, 57

Constitution, 18

Cricket-playing law, ro6

House at Suva, 6, 22, 122

Penal system, humours of the, $17-25$

Post, 25, 129

Under the present Governor, 15

United States and King Thakombau, II, I3

Viti Levu, seat of Fijian Government, 7

Government armed native constabulary, 9, 21, 86

Gratitude, $71-72$

Great Britain refuses King Thakombau's offer, I I
Grief, I $25-126$

Guavas, 60, 63, 80, I I 7

Guinea-grass, 54

Gum, I I 2

Arabic, 28

Hair-dress, $45-47,75,78,105$

Half-castes, 8, 15 census of, 15

Heathen days of Fiji, ro

Hemp, sisal, 28

Hibiscus, 63 , II 7

High Commissioner of the Western Pacific, 14

History, I0-I 7

Discovered by Tasman, ro; Vatoa sighted by Cook, ro; Moala, observations made by Bligh, ro; First chart constructed by D'Urville, ro; Cannibalism, I I ; Civilisation, I I ; Thakombau, King, one of the worst monsters of cruelty since Nero, I I ; Islands offered to Great Britain in 1858 , $1 \mathrm{r}$; Richest prize in the South Seas goes a-begging, II ; Australian emigrants, 12 ; Tonga tribes give serious trouble, I 2-I3; Fiji a Crown Colony in 1874, $\mathrm{I}_{3}$; British form of government, $\mathrm{I}_{3}-\mathrm{r} 4$

Honey-birds, I I 6, I 17

Horse of the author, Tanéwa, $54-55,60,63,65,68,77$, 84, I08-I 10

Horses, 57

House, a mountain, 4I-44, 45

of a mission-teacher, $49-50$ of the Buli of Mavua, one of the finest in Fiji, 77 of the good Buli of LembaLemba, 70-73

of the Turanga Lilewa, 6465 
Humour, 17-25, 89-90

Hurricanes, 7 , I 31

Hymns, 53

Idols, see Religion

Illustrations, list of, xi

Imports, I 7, 57

Improvements

British, I 3-I 4, I 8

early missionaries, Io, II, I 3, I 8

planters and traders, I 8

Sunday church, I 2 I

under the present Governor, 15

Indians, 8, I 5, I6, I 7, 31, 86, I30,

Industries (see also Agriculture and Products)

building, $2 \mathrm{I}$

cattle-ranching, I 32-I 37

cocoa-planting, II 9

Colonial Sugar Refining Company, I 7, 3I, 86

exports, I 7

Fiji, r6, I7

imports, 17,57

roadmaking, $2 \mathrm{I}$

timber, I 7 , I9, 57, IOI, I I $2-$ I I 9,127

vanilla plantation, I 29, I30I 32

Vitu Levu, 7

Insects, see Animal life

Ironwood, 89

Islands, see Geography

Jails, I 7, I 8-25

Kaisi, or commonalty, relation to chiefs, $95^{-96}$

Kandavu, a province, I 4

King's service, Fijian term for being in jail, 22

Koronisingana, 73,74

Lali, a canoe-shaped wooden drum, 53
Lambasa, principal port of Vanua Levu, 83,86 , I I 3 , II 7,129

Land-tenure, I5

La Pérouse, 98

Latitude, 6

Laws, see Government

Leaf-insects, II 7

Legislative council of twelve for British Governor in Fiji, I 4

Lemba-Lemba, an important town, 70

Lemons, $36,59,60,63$, I I 4

Leprosy, 102-103

Levuka, former capital of Fiji, 7 , I 3 , I I I

Lianas, $36,39,83,107$, I I 5, I 18

Limes, 28

List of illustrations, $x i$

Livingstone, explorer, 92, II 6

Longitude, 6

Lotus, 9

"Luggage, 34-3,5

"Luveni wai" worship, a mixture of "miracle play," devil-worship, and murder, I 2 I-I 22

Maafu, a powerful chief of Tonga, $\mathrm{r} 3$

Macuata, Roko Tui, or Prince of, IO3

Mails, carried by convicts, 25 , I 29

Maize, I 9

Makarita, wife of the Roko Tui Macuata, I04-I05

Malaria, 68

Mammals, see Animal life

Mandarin orange, 63

Mangaia, Island of, I 6

Mangoes, 75

Manufactures, see Industries

Massacres, see Murders

Mavua, the biggest town on the Singatoka River, 76, 78, 8I

Mavuan sunset dance, 76

Mbili-mbili, a small bamboo raft, $69,73,74$ 
Mbuli, term for a chief, I 4, 47, 49

Meké-meké, a sing-song dance, $77-79,105,106-107$

Missionaries, Iо, II, I3, I 8

Moala, Island of, ro

Mosquitoes, 7

Mountain house, $4 \mathrm{I}-44,45$

Mountains, see Geography

Mulberry-tree, Io

Murders, massacres, tortures and cannibalism

cannibal days of Fiji a thing of the past, IO-II, 29, 37 chief diversions of a Fijian's life, 18

during Thakombau's reign, II

"luveni wai," I 2 I-I 22

Tha Levu, I 22-I 23

Music, the soul of Fijians, 9

Nambukuya, the city of a dream, $40,47-54,55,58$

Nandrunga, a small village in Fiji, 40,58

Nanduri, a handsome town, 103-

Native $107,128,129$

banks, 9

census, I 5

verses, impromptu, 45

Natives, chiefs, 95-96

civilised become excellent soldiers, 9

decline of population, 15,16

dress, $34,35,45,53$

eating and talking, two

great ends of a Fijian's

existence, 50-5I, 56-57,

$65,71,75,76,79,80$

gratitude, $71-72$

grief, I $25-126$

humour, I 7-25, 89-90

kaisi, or commonalty, 95-96

Mavua, 78

mixture of population, 8

New Hebrides, 9

regard for whites, $86-87$
Natives

of the Solomons, 9

of Suva, 6-ro

women, 43-44

Natuatuathoko, a mountain fortress town, $57-58,60,61,62$

Natural resources, see Products, Plant life, Agriculture, and Industries

Ndalo, one of Fiji's most important roots, 49, 51, 71, 95, I IO, I I 4

Ndreketi River, ror-rig, I 21 , I 22, I 28

New Caledonia, 38

New Hebrides, 9

Ngeo, Island of, I 13

Niue, Island of, 16

Number of islands in Fiji, 6

Oranges, $28,47,54,60,62,63$. $64,75,80,92$, II 4

Orchid, 38 , II 5

Outfit, 30, 32, 33

Ovalau, Island of, 7

Palms, 8, 45, 92, I33 areca-nut, 28

Pandanus, or screw pine, 33, 42, 97 prairies, 33,37

Papya, 28

Parrots, II 6

Paw-paws, 75

Peanuts, I 7

Penal system, humours of the, I 7-25

Pepper, 79

Pigs, 53, 57, 65, 71, 74, 79, 95, IO 4 , I I 4 , I I 7

Pine-apples, 28, 98

Pini, or tunic, $49,104,105$

Plant life (see also Products) allamanda, I 23

azalea, 39

bamboo, 36, 4I, 42, 44, 45, $48,60,6$ I $, 63,74,76,97$, I 24 bread-fruit tree, 42 cocoa-palm, 79, I 8 
Plant life

guinea-grass, 54

ironwood, 89

lianas, $36,39,83,107$, II 5 , I 8

lotus, 9

mangoes, 75

mulberry-tree, Io

orchid, 38 , II 5

palms, 8, 45, 92, I 33

pandanus, or screw pine, 33 , 42,97

potatoes, wild, II 8

rain-palms, 8

salvia, scarlet, 39

shaddocks, 38

sinnet, or cocoanut fibre, 42

tree-ferns, 38

tuberoses, 39

Pleasure parties, 9

Police-stations, I 8

Politics, see Government

Polynesian labourers, 3 I

Population, I5, 16

Possibilities, 57,59

Post, 25, I 29

Prawn, river-, 55

Prayers, 53

Prince of Macuata, or Roko Tui Macuata, I03

Prince William Islands, Io

Products, see also Agriculture, Industries, and Plant life

allspice, 28

annatto, 28

areca-nut palms, 28

arrowroot, 28, 105

bamboo, 36, 4I, 42, 44, 45, $48,60,6$ I $, 63,74,76,97$, I 24

bananas, $17,28,35,42,47$, $48,53,54,67,80,105$, I I0

bau ndina, a rose-red wood, II 3

bau vundi, a kind of cedar, I 3

bread-fruit tree, 42

bua-bua, the boxwood of the Pacific, I I 2
Products

cassia, 28

castor oil, 28, I3 I

cevua, or bastard sandalwood, I I 2

chestnuts, II 4, II 8

chillies, 28

citrons, $36,38,59$

cloves, 28

coca, erythroxylon, from

which cocaine is extracted, 28

cocoa, 28, 79, II 8, II 9

cocoanut, $42,55,67,7 \mathrm{I}, 73$, $75,78,87,93$, 105, 108, I IO, I I 7, I 26

coffee, I 7,58 , 80

copra, the dried meat of the cocoanut, I $2,17,133,134$

cotton, $\mathrm{x} 2,3 \mathrm{I}$

croton oil, 28

crotons, 47,60

curry, 28, I 26

dakua, wood resembling the

New Zealand kauri pine, II 2 , II 9

dracænas, 47,60

drugs, I 7

ginger, 28

guavas, $60,63,80$, Ir 7

guinea-grass, 54

gum, I 2

Arabic, 28

hibiscus, 63, II 7 ,

lemons, $36,59,60,63$, II 4

lianas, $36,39,85,107$, II 5 , I 8

limes, 28

maize, I9

mandarin orange, 63

mangoes, 75

ndalo, one of Fiji's most important roots, $49,5^{I}$, $7 \mathrm{I}, 95, \mathrm{IIO}, \mathrm{II} 4$

oranges, $28,47,54,60,62$, $63,64,75,80,92$, I I 4 pandanus, or screw pine, 33,42 


\section{FIJI AND ITS POSSIBILITIES}

\section{Products}

papya, 28

paw-paws, 75

peanuts, 17

pepper, 79

pine-apples, 28,98

potatoes, wild, I I 8

ramie fibre, 28

rice, 24, II 3

sandalwood, I I 2

savairabunidamu, a darkred wood, I 2

shallots, 79

sinnet, or cocoanut fibre, 42,50

sisal hemp, 28

sugar, I $2, I_{7}, 3 \mathrm{I}, 67,86,88$, 89,97, I IO, I I 3, I I $4, I_{2} 8$ taro, 37,47

tea, I $7,7 \mathrm{I}, 72,80,84,88$, I I 3 , I I 4 , I 27

teak, 28

timber, I 7, I9, 57, I I I, I I 9 , tobacco, I6, I 9, 53, 7I, 72, 89 , I 25, I 28

turmeric, excellent for curries, 28

vanilla, I $7,28,67,74,80$, I 29 , I $30-132$

vesi, teak-like wood, I I 2

West India arrowroot, 28

yaka, the rosewood of the Pacific, I I 2

yam, $22,37,42,47,48,50$, $5 \mathrm{I}, 53,55,59,65,7 \mathrm{I}, 75$, $76,79,94,95$, II 4, II 8 yanggona, the "kava" of the Eastern Pacific, 5I$52,59,77,96,105$

Providence, Bligh's ship, to I 27

Rain-trees, 8

Ramie fibre, 28

Regard for whites, 86-87

Religion church, 53

hymns, 53
Religion

"luveni wai" worship, a mixture of "miracle play," devil-worship, and murder, I 2 I-I 22

prayers, 53

"tembe-tembe," devil-worship, I 22-I 25

Reptiles, see Animal life

Resources, see Products, Agriculture, and Industries

Réwa River, 69

Réwa Road, 3 I

Rice, 24, II 3

River-crayfish, 65, 7I, 79, 104, I I 4 prawns, 55

Rivers, see Geography

Roadmaking, 2 I

Roko Tui, degree for the province princes, I 4

Macuata, or Prince of Macuata, I03, 104

Rotumah, Island of, I 5

Rulers

Buli, term for a high chief, 70

Maafu, a powerful chief of Tonga, 13

Mbuli, term for a chief, I4, 47,49

Robinson, Sir Hercules, British Governor of Fiji, I 3, I 4

Roko Tui, degree for the province princes, I4

Macuata, or Prince of Macuata, IO3, IO4

Thakombau, King of Fiji, one of the worst monsters of cruelty since Nero, I I, I $3,18,62,104$

Thurn, Sir Everard im, present Governor of Fiji, I 4-I 5, 39

Turanga ni Koro, degree for the chief of a town, I $4,5 \mathrm{I}$, 52,55, IO2, II 4 
Salvia, scarlet, 39

Samoans, 8

Sandalwood, i 2

Savairabunidamu, a dark-red wood, I I 2

Sawmill, I I I, II 3

Scorpions, i 7

Senganga, the "back of beyond," I $2 \mathrm{I}-\mathrm{I} 38$

Serpents, I 6

Shaddocks, 38

Shallots, 79

Sharks, 69, 98-99

Sheep, 57

Shipping, see Industries

Shower-bath in Nanduri, 104

Sickness

chest troubles, I 6

dysentery, 7

European diseases, 16

fever, $7,68,84$

leprosy, IO2-103

malaria, 68

skin diseases, Ior

"thoko," a skin disease, IOI

Singatoka and highlands (Tholo

West Country), 132

River, 60, 63, 67, 68, 80, $8 \mathrm{I}, 88$

Valley, 56, 75

Sinnet, or cocoanut fibre, $42,5^{\circ}$

Sisal hemp, 28

Skin diseases, I0 I

Snakes, i 6

Social conditions, I 7

Society, I04

Solo dancing, 9

Solomons, cannibal group, 9

Somo-somo, a horse from Vuo, 87,90, 108-I10, I 29

South Seas, II, I 5,27

Speke, explorer, $30,56,92$

Stanley, $30,36,56,83$, I I 6 , I 28

Stick-insects, I I 7

Stock, I 7

Sugar, I 2, I 7, 31, 67, 86, 88, 89, 97 , IIO, II 3, II 4, I 28
Sugar-cane meké-meké, 106-107

Sulu, the national kilt of the Fijians, I $4,23,34,45,49$, $53,55,62,70,76,78,79$, $84,105,106,123,128$

Sunset dance, Mavuan, 76

Suva, present capital of Fiji, 5,

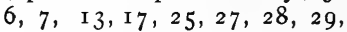
$3 \mathrm{I}, 67,80,8 \mathrm{I}, 85,88, \mathrm{ro} 3$, I I I, II 7 , II 9, I 22,128 , I 30, I 33, I 34

Government House, 6, 22

Harbour, 27

Society, 27

Systems, see Government

"Tabu kaisi," mat forbidden to commoners, 102

Tamavua River, 27

Tambalé, a tiny village, 47

Tambia, a place to let alone, IOI-IO3, IO4, II 4

Tanéwa, the author's horse 54$55,6 \circ, 63,65,68,77,84$, I08-I 10

Taro, 37, 47

Tasman, discoverer of Fiji, I0 Taviuni, a great island near Vanua Levu, I7, II5, I32137

Tavu River, 58

Taxes, 9, 19, 22

Tea, I 7,7 I $72,80,84,88$, II 3 , I I 4, I 27

Teak, 28

"Tembe-tembe," devil-worship, I 2 2-I 25

Temperature, 7,50

Tevoro, or devil, I 23-I 25

Thakombau, King, one of the worst monsters of cruelty since Nero, II, I3 , I8, 62 ro 4

birthplace, Bau, 62 monument at Suva, 27

Tha Levu (Bad Lot), a hereditary devil-priest, I $22-$ I 23

"Thoko," a skin disease, ror 
Tholo West Country (Singatoka and highlands), I 32

Thurn Lady im, wife of present Governor of Fiji, I 5

Sir Everard im, present Governor of Fiji, I4-I5, 39

Ticks, II6, II 7

Timber, 17, I 9, 57, IOI, III-II9, 127

Timor, 10

Tobacco, I6, I9, 53, 7I, 72, 89, I 25, I 28

Tonga, a group of islands, rival of Fiji, I 2-I 3, I 6

Tortures, see Murders

Towns, see Geography

Trades, see Industries

Tram-line, 24

Transportation, see Industries

Tree-ferns, 38

Tribe dancing, 9

Tropical forest, 37-39

Trunk, Fijian, 34

Tuberoses, 39

Tumba, a town on the Ndreketi River, I07, III-II9, I 22, I 28

Tunic, see Pini

Turanga Liléwa, a chief of importance, $64-65$

Turanga ni Koro, term for the head man of a town, I4, $5 \mathrm{I}$, 52,55, IO2, II 4

Turmeric, excellent for curries, 28

United States Exploring Expedition, ro

United States Government, I I, 3 I

Vanilla, I 7, 28, 67, 74, 80, I29, I 30-I 32 plantation, $23-25$, I30-I 32
Vanua Levu (Great Land), 6, 23, 83-99, II, II 4, I 27 , I 29, I 30

Vatua, Island of, ro

Vegetables, see Plant life, and Products

Verses, impromptu, 45

Vesi, teak-like wood, I I 2

Village, a mountain, 45

Villages, see Geography

Viti Levu (Great Fiji), most important island in the archipelago, $6,7,39,83$, $86,87,88$, I I 3 , I I 4

Vuo, 87,98

Wainikoro, 87, 88, 9I, 96

Wainikoro River, 9I

Wall of Suva jail, a joke, r 9-20

Water-pipes in Nanduri, IO4

Waterways, see Geography

Waves of the Sea, one of the most celebrated dances, 9IO

Wedding dance, 9

West India arrowroot, 28, 105

Whist in Nanduri, I05

Wild boars, I I 6, II 7

cats, I I6, I I 7

potatoes, I I 8

Women, 43-44

Yaka, the rosewood of the Pacific, I I 2

Yam, 22, 37, 42, 47, 48, 50, 5I, $53,55,59,65,71,75,76,79$, 94,95 , I I 4 , I I 8

Yanggona, the "kava" of the Eastern Pacific, 5I-52, 59, $77,96,105$

Zoölogy, see Animal life 


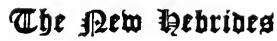

Route: Sydney, I39, I40. Port Vila, I43-I44. Vila, I44. Mélé road, r6o. Undine Bay, I6r. Efaté, I62-r76. Mélé beach, I62. Mélé Island, I62. Through the "bush," I62-163. Sou'West Bay, I85-187. Malekula, I87-235. Ten Stick Island, I9oI9I. Bilyas, I93-195. Tanna, the southernmost of the New

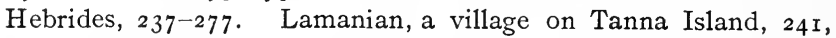
242. Imale, 243-253. Lenakil, 253-255. Whitesands, 257 .

Advertisement for New Hebrides I 45

Adzes, 220

Agriculture (see also Products) plantation life, $163-173$ sheep-farming at Erromanga, 275

Almonds, 163

Alunk, a kind of image, 228

Amat (high chief), a kind of image, 228

Ambang, name for the Bwiliau image, 228

Ambrym, I 78, 275, 276

Amils, village squares, 226, 229

Aneityum, 238, 275

Anglo-French Convention, I39, I 50, I 74

Anglo-French dilemma, I 47-I 54

Animal life

fruit bat, 202

goat, 165

locust, 248

mosquito, I 73

parrot, 163,202

pig, I63, I $81,164-185,203$, 2I $3,215,227,228,247,268$ pigeon, 163,179

spider, 243

wild boar, 163,202

Aniwa, 259

Aoba, 276

Arch-idol, 229-230

Arrowroot, 165

Atamat and Fintimbus, dancing, 2 I I-2 I 7
Aurora, 276

Australia, I 40, 255

Balanrum, a kind of image, 228

Balias, a kind of image, 228

Bamboo, 209, 220

Bananas, 165

Banyans, 16 $3,201,243,244$, $245,248,257$

Bat, fruit, 202

Bataru, name for the Alunk image, 228

Bilyas, I93-195

Biology, see Animal life

Bird's-nest ferns, $20 \mathrm{I}$

Boars, wild, 163,202 tusks, $184-185,202,212$

Borde, Monsieur, French Commissioner, I49, I58, I69, I 74

Botany, see Plant life

Bracelets, 2 I0

Bread-fruit, 2 I 9

British Solomons, I 46, 255

Buildings

bungalow of Capt. Ernest Rason, British Commissioner, I 44

"hamal," I 82-1 83, 205, 209, 2 I $8-220$

mission house, Malekula, I 93

planter's home, I63-r64

Bungalow of Capt. Ernest Rason, British Commissioner, I 44 
"Bush" country, r $62-16_{3}$

"Bush-lawyer" vine, I6I

Bushman's Bay, 233

Bwila, name for the Bwilbon image, 228

Bwilbon, a kind of image, 228

Bwilian, a kind of image, 28

Cannibalism, see Murders

Canoes, 185

Carteret, Captain, I 47

Caste-superstitions, 204

Cities, see Geography

Clothes, I 55, I 58 , I $80-18 \mathrm{I}, 202$

Cocoanuts, $163,219,228$

Cocoa-palm, i 79

Coffee, I 46, I60, I65, I68, I 72 , I 79

Cook, Captain, explorer, I 47, I 89,274

Copra, I 46, I5I, I 79, I85, 253 , 261,263

Coral, I 62

Cottonwood, I 44, I87

Council of war, $251-252$

Dancing

Atamat and Fintimbus, 2 I I -2 I 7

idol, I 99, 209-2 I 7

Sing-Sing ground, 184 solo, 2 I I

De Bougainville, 147, I 89

De Quiros, Portuguese explorer, I 47

Discovery of New Hebrides by the Portuguese, De Quiros I 47

Diseases, see Sickness

D'Oyly, Commander H., of the Pegasus, 196, 234

Drum-sticks, 220

Dynamite, I $58-159$

Earrings, 2 Io

Education of the natives, 156

Efaté, I 57, I62-176, 201

Epi, 178
Erromanga, the "Martyr Isle," 259,276

Events on a plantation, $165-167$

Explorers

Carteret, Captain, I 47

Cook, Captain, I 47, I 89, 274

De Bougainville, I 47,189

De Quiros, Portuguese, 147 Stanley, 26I

Fear author at Whitesands, 260

Ferns, bird's-nests, 201

Fern-tree, 227, 228

Fever, I65, I73, I88, 198, 201 , $210,248,267,277$

Figs, I63, 26I

Fintimbus, and Atamat, dancing 2 I I-2 I 7

Fire-arms, $157-158$, I 74, 265

Fishing with dynamite, $158-160$

Flowers, see Plant life

Food products, see Products

France's reasons for acquiring New Hebrides, I 48-I 49

"Frigate" bird, 205

Fruit bat, 202

Geography

Ambrym, I 78, 275, 276

Aneityum, 238, 275

Aniwa, 259

Aoba, 276

Aurora, 276

Australia, I 40, 255

Bilyas, I 93-195

British Solomons, I 46,255

Bushman's Bay, 233

Efaté, I 57, 162-176, 201

Erromanga, the "Martyr Isle," 259,276

Imale, 243-253

Lamanian, 24I, 242

Lenakil, 238, 253-255

Lowinnie, 244

Lumbumbu, 196

Maewo, Island of, 227,276

Malekula, or Mallicollo, I $76-235,237,276$ 
Geography

Maskelyne Islands, 227

Mélé Beach, $\mathrm{I}_{2}$

Mélé Island, 162

New Caledonia, 140, I 47 I 49, I 50, I 53

New Guinea, I 49

Paama, I 78

Pentecost, 276

Port Vila, I 43-I 44

Queensland, 265, 266

Rano, Island of, I 80,234

Santo, 237,276

Solomons, 146,255

South Seas, 162

Sou'-West Bay, I77, I85I $87,190,217,220$

Sulphur Bay, 264, 267

Sydney, I 39, I 40, I64

Tanna, the southernmost of the New Hebrides, I 75-I 76, 20I, 237-277

Ten Stick Island, I 90-I9I

Undine Bay, I6r

Uripiv, 220

Vila, "capital" of New Hebrides, I 43-I 45, I 57,238

Wala, a strange little island off the coast of Malekula, I 79-1 $80,184^{-2} 34$

Whitesands, 257

Ginger, 213

Goat, I 65

Government

Australian view of the New Hebrides, I 40

men-of-war, I69, I74, 187, I 89, 190, I99, 233

Tariff laws, "White Australia," I39, I 73

Grain, I49

Graveyards, I 58, I 83

Guava, I44, I67

"Hamal," I82-I83, 205, 209, 2 I $8-220$

Heads, conical, 22I-223

Hibiscus, 0.19
History

Anglo-French Convention, I 39, I 50, I 74, I76. AngloFrench dilemma, I 47-I 54 . Discovered by the Portuguese De Quiros, in 1605 , 147. Offers of exchange for New Hebrides, I 48 , 153. France's reasons for acquiring New Hebrides, I 48-I 49

Hurricane, 203

Idols

in dancing, I 99, 209-2 I 7

in Malekula, 225

in the Sing-Sing ground, I 83

Imale, 243-253

Insects, see Animal life

Islands, see Geography

Journal of the Royal Anthropological Soc'y of Australia, 226-229

Kava, 247

Killing-mallets, 220

Lamanian, 24I, 242

Land tenure, I 73

Laws, see Government

Leggatt, Mr. Watt, missionary, $226-230$

Lemon-trees, I6 I

Lenakil, $238,253^{-2} 55$

Lever Brothers, manufacturers, I 46

Liana, I6 $3,200,201$

Liquor, I 74

Locusts, 248

Lovwis, name for the Matalau image, 228

Lowinnie, 244

Lumbumbu, I 96

Maewo, Island of, 227, 276

Maize, I 46, г6。

Malaita, S.S., 274 


\section{FIJI AND ITS POSSIBILITIES}

Malaria, I 73, 277

Malekula, $176-235,237,276$ idols, 225

Mallicollo, see Malekula

Mammals, see Animal life

Mangrove, 200

Maskelyne Islands, 227

Maskelynes, kind of image, 227

Matalau, a kind of image, 228

Mélé beach, I 62

Island, 162

road, 160

Meleun, a kind of image, 228

Men-of-war, I69, I74, I87, I89, I 90, I 99,233

Meurthe, French man of-war I 89 , I 93 , I 95,196

Millet, I 46, I 68

Missionaries, I 46, I 52, I 56, I 78 I 79, $190,225^{-229}, 238$

Mission house, Malekula, I 93

Mosquitoes, I 73

Mountains, see Geography

Mummies, 21 8-220

Murders, massacres, tortures, and cannibalism

Australian view- of New Hebrides, I 40

Malekula, I $90,203,2$ I 2

no redress for, I 50

Sing-Sing ground, 183

Tanna, 239

Mythology, Malekula, 229

Nahau, name for the Taresing image, 228

Natemate, 227-229

National dress of Malekula, I80I 8 I

Natives

clothes, I 55 , I 58

education, 156

fear of author at Whitesands, 260

free with fire-arms, I $57^{-1} 5^{8}$,

I 74,265

gorilla-like, I 56

honesty, I 56
Natives

murderous, filthy and unhappy brutes, I $_{5}$ I

national dress of Malekula, I 80-I 8I

nobility in Malekula, I8 I

population, $145^{-1} 4^{6}$

sullen and ugly, I 55

Wala, i 80

wives in New Hebrides, I $8 \mathrm{I}-\mathrm{I} 8 \mathrm{~s}$

women in Malekula, 205207, 210

women in Tanna, 249

Natural resources, see Products, Plant Life, and Agriculture

"Netik," a witchcraft belief, $250-25 \mathrm{I}$

New Caledonia, I40, I 47, I49, I 5 O, I 53

New Guinea, I49

Nobility in Malekula, I8 I

Number of islands in the New Hebrides, I 45

Offers to exchange for New Hebrides

Manihiki Islands, I 53

Mauritius, I 53

Rapa, Island of, ${ }^{4} 8$

Oranges, I 65

Orchids, 201

Paama, i 78

Palms, I 44, I 58, I 79, 201, 2 I 3 , $249,260,269$

Pandanus, I80, 2 I0, 249, 269

Parrots, I63, 202

Pegasus, H.M.S., I 75, I 89, r 93 , 235

Pentecost, 276

Peppers, I 65

Pigeons, г63, I 79

Pigmies, 187,205

Pigs, I63, I 8I, I 84-I $85,203,2$ I 3 , $2 I_{5}, 227,228,247,268$

Pig's tail, 202, 2 I 2

Plantation life, I6 $3-173$ 
Planter's home, I $6_{3}-16_{4}$

Plant life (see also Products) banyans, I63, 20I, 243, 244, $245,248,257$

"bush-lawyer" vine, I6I

cottonwood, I 44, I 87

ferns, bird's-nests, $20 \mathrm{I}$

fern-tree, 227,228

guava, I 44

mangrove, 200

orchids, 201

palms, I 44, I 58, I 79, 20I, $213,249,260,269$

Poisoned arrows, I87, I88, 230232

Population, I $45^{-1} 46$

Port Vila, I 43-I 44

Potato, 163

Presbyterian babies, I $78-$ I 79

Products, see also Plant life, and Agriculture

almonds, 163

arrowroot, I67

bamboo, 209, 220

bananas, 165 ,

bread-fruit, 2 I 9

cocoanuts, $163,219,228$

cocoa-palm, I 79

coffee, I46, I60, I65, I68, I 72, I 79

copra, I 46, I $5 \mathrm{I}, \mathrm{I} 79, \mathrm{I} 85$,

$253,261,263$

coral, $\mathrm{I}_{2}$

cottonwood, I 44 I 87

figs, $163,26 \mathrm{I}$

ginger, 213

grain, I 49

guava, I 44, I67

hibiscus, 249

kava, 247

lemons, I6r,

lianas, $\mathrm{I} 63,200,20 \mathrm{I}$

liquor, 174

maize, I 46 , I 60

millet, I 46, I 68

oranges, 165

pandanus, 180, $210,249,269$

peppers, 165
Products

potatoes, I 63

rose-apples, $26 \mathrm{I}$

sinnet, 202, 222

sugar, I 66

tariff laws, White Australia, I 39, I 53

taro, $\mathrm{I}_{3}, 20 \mathrm{I}, 2 \mathrm{I} 4$

tea, I 65, I 66,

tobacco, I5I, I 58, 214, 219, 23I, 250, 262

tomatoes, I 65

tree-melons, $26 \mathrm{I}$

wood-ash, $20 \mathrm{I}$

Protectorate, I 74

Queensland, 265, 266

sugar country, 240

Rainfall, 200

Rano, Island of, I 80, 234

Rason, Capt. Ernest, British Commissioner, I 44, I 49, I 58

Religion I 69, I 74

"frigate" bird, 205

idols in Malekula, 225 in the Sing-Sing ground, 183

Rivers, see Geography

Rose-apples, 26I

Santo, 237,276

Sarguey, murdered white trader, I 95, I 96-I 98

Savanral, name for the Balanrum image, 228

Schooner threatened, 232-233

Sea-chief, an ill-natured, $233^{-2} 35$

Sheep-farming,atErromanga, 275

Sickness fever, I65, I 73, I 88 , I 98 , 20I, 210, 248, 267, 277 malaria, I 73, 277

Sing-Sing ground, $179,183-184$ cannibalism on, 183

dancing on, I 84 idols on, 183 


\section{FIJI AND ITS POSSIBILITIES}

Sinnet, 202, 222

Size of New Hebrides, 139-140, I 45

Skulls, 22 2-2 23

Soap-making, I 46, 26 I

Solo dancing, 2 I $\mathrm{r}$

Solomons, I 46, 255

South Seas, 162

Sou'-West Bay, I77, I85-187, I 9o, 2 I 7, 220

Spiders, 243

Stanley, 26r

Sugar, 166

Sulphur Bay, 264, 267

Sydney, I 39, I 40, r64

Tan melev, a kind of image, 228

Tanna, southernmost of the New Hebrid€s, I75 - I76, 201, $237^{-2} 77$

Taresing, a kind of image, 227

Tariff laws, White Australia, I39, I 73

Tea, I65, I66, 259

"Temes," images of the dead, 226

Temperature, I 79

Ten Stick Island, I 90-I 9 r

Tobacco, I 5 I, I 58, 2 I 4, 2 I 9, 23 I, 250,262

Tomatoes, $6_{5}$

Tortoise-shell, 2 Io
Taro, I63, 201, 214

Tortures, see Murders

Tree-melons, $26 \mathrm{r}$

Tribal-fighting, $175^{-1} 76$

Undine Bay, r6r

Uripiv, 220

Vaucluse, French warship, 175

Vila, "capital" of New Hebrides, I $43^{-I} 45$, I 57,238

Villages, see Geography

Vilvil, name for the Vilvilbon image, 228

Vilvilbon, a kind of image, 228

Volcano, 257, 267-275

Wala, a strange little island off the coast of Malekula, I 79I 80, I $84^{-2} 34$ natives of, 180

Waterways, see Geography

White Australia tariff laws, r39, I 53

Whitesands, 257

Wives in New Hebrides, $181-182$

Women in Malekula, 205-207, 2 Io

in Tanna, 249

Wood-ash, 201

Yam, I63, I79, I80, I8I, I82, 203, 205, 206, 2 I 4, 2 I 7, 242, 245

Zoology, see Animal life.

\section{Jorfolk Jgland}

Adams, sailor, last survivor of mutineer crew, 282

Bridges, 285

British West Indies, 280

Bananas, 292

Barracks, 284

Bishop, 289

Bligh, Commander, 280

Bloody Bridge, $29 \mathrm{I}$

Bounty, British man-of-war, 280, $285,286,287,292$

Bread-fruit trees, 280
Cancer, 293

Carteret, discoverer, 28r

Cattle, 290

Celebrations, 292-293

Christian, Lieutenant of H. M. S. Bounty, 28I, 287

Church of England Melanesian Mission, 290 
Churches, 284

Clarke, Marcus, author of "For the Term of His Natural

Clergy, 289 Life," 283

Coffee, 292

Consumption, 293

Convict station, $283-284$

Cook, explorer, 283

Coral, 280

Corn, 289

Courthouse, 284

Dancing, 292

Discovery by Carteret, $28 \mathrm{I}$ by Cook, 283

Drake, Captain and Mrs., 286

Dutch East Indies, 280

Emigration, 283

Geography

British West Indies, 280

Dutch East Indies, 280

Mount Pitt, 289

Nepean Island, 29I

New Hebrides, $29 \mathrm{I}$

New South Wales, 286

Philip Island, $29 \mathrm{I}$

Pitcairn, named after midshipman who first sighted it, 28I, 282, 287, 293

Solomons, $29 \mathrm{I}$

Sydney, 279, 288

Tahiti, 280, 28I

Tasmania, 283

Timor, Dutch East Indies, 280

Government Commission, 285

Government House, 286, 289

Grapes, 291

Graveyard, 284

Guavas, 29I

\section{History}

Discovered by Carteret in I $767, \quad 28 \mathrm{r}$. Pitcairn named after the midship-
History

man who first sighted it, 28I. Adams, last survivor of mutineer crew, 282 .

Nobbs,new Governor, 282. Discovered by Cook in I 744, 283. Emigration of Pitcairn people to Norfolk Island, 283

Horses, 290

Houses, 290

Inlay work, 29I

Kumara, or sweet potato, 289

Lemons, 292

Manners, 288-289

Melons, 292

Mount Pitt, 289

Music, 287

Natives descendants, $287-288$ manners, 288-289 women, Tahitians, 280,286 287

Nepean Island, 29I

New Hebrides, $29 \mathrm{I}$

New South Wales, 286

Nobbs, new governor, 282

Onions, 290

Oranges, 292

Passion-fruit, 29I

Peaches, 29I

Pheasants, 290

Philip Island, 29I

Pigs, 292

Pines, 290

Pitcairn, named after midshipman who first sighted it, $28 \mathrm{r}, 282,287,293$

Plague, 279

Population, 279, 286 


\section{FIJI AND ITS POSSIBILITIES}

Potatoes, 289

Prison, $283^{--284}$

Products

bananas, 292

bread-fruit trees, 280

cattle, 290

corn, 289

grapes, $29 \mathrm{I}$

guavas, 29 r

horses, 290

kumara, or sweet potato, 289

melons, 292

onions, 290

oranges, 292

passion-fruit, 29 I

peaches, 29I

pheasants, 290

pigs, 292

potatoes, 289

quail, 290

strawberries, 292

sugar, 288

tea, 288,289

tobacco, 287

Quails, 290

Roads. 285

Schools, 284
Sickness

cancer, 293

consumption, 293

Size, 279

Solomons, 291

Stained-glass windows by Burne-Jones, 29I

Storehouses, 284

Strawberries, 292

Sugar, 288

Suicide, epidemic, 283

Sydney, 279, 288

Tahiti, 280, 28I

Tahitians, $280,286,287$

Tasmania, 283

Tea, 288,289

Tennis, 289,292

Timor, Dutch East Indies, 280

Tobacco, 287

Victoria, Queen, 285

Whale-oil, 288

Whalers, 288,290

Whaling industry, 289

Widows, 290

Women, 280, 286, 287 

THIS BOOK IS DUE ON THE LAST DATE STAMPED BELOW

AN INITIAL FINE OF 25 CENTS WILL BE ASSESSED FOR FAILURE TO RETURN THIS BOOK ON THE DATE DUE. THE FENALTY WILL INCREASE TO 50 CENTS ON THE FOURTH DAY AND TO \$1.00 ON THE SEVENTH DAY OVERDUE.

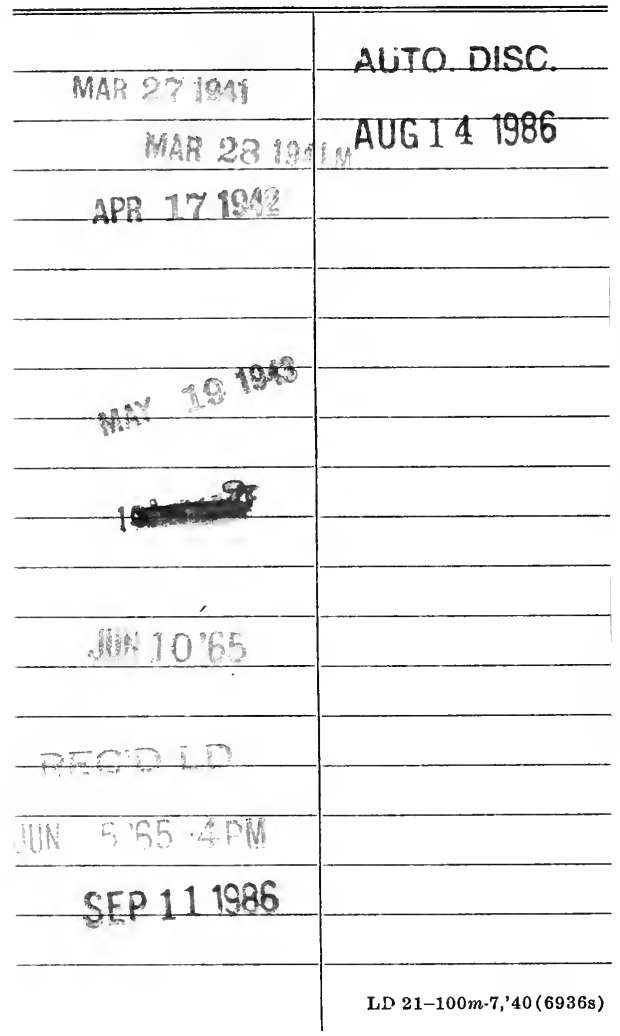


GENERAL LIBRARY - U.C. BERKELEY 

$\ldots \ldots$ ${ }_{-1}$ -1

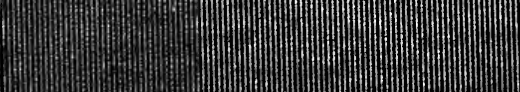
$\mathbf{y}^{-3}$

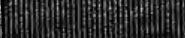

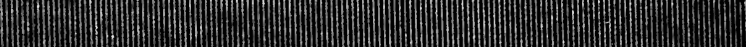

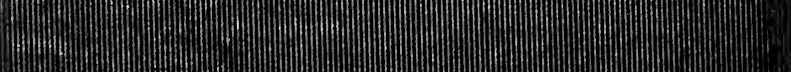

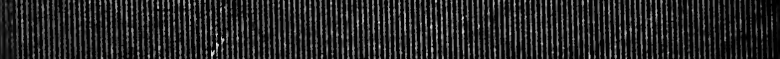
_.

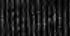
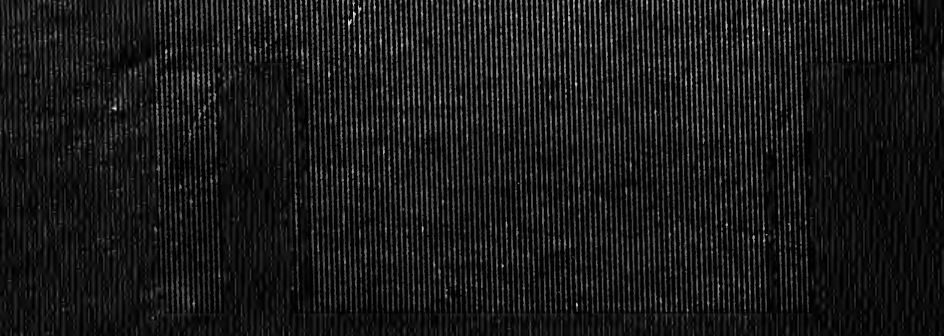